University of Michigan Law School

University of Michigan Law School Scholarship Repository

\title{
Government Misconduct and Convicting the Innocent: The Role of Prosecutors, Police and Other Law Enforcement
}

\author{
Samuel R. Gross \\ University of Michigan Law School, srgross@umich.edu \\ Maurice J. Possley \\ Kaitlin Jackson Roll \\ Klara Huber Stephens
}

Available at: https://repository.law.umich.edu/other/165

Follow this and additional works at: https://repository.law.umich.edu/other

Digipalrt of the Civil Rights and Discrimination Commons, Criminal Law Commons, Law Enforcement and Cemmogrs Commons, and the Rule of Law Commons

Network

\section{Logo}

Samuel R. Gross, senior editor. "Government Misconduct and Convicting the Innocent: The Role of Prosecutors, Police and Other Law Enforcement." M.J. Possley, K.J. Roll, and K.H. Stephens, co-authors. The National Registry of Exonerations, (2020).

This Report is brought to you for free and open access by the Faculty Scholarship at University of Michigan Law School Scholarship Repository. It has been accepted for inclusion in Other Publications by an authorized administrator of University of Michigan Law School Scholarship Repository. For more information, please contact mlaw.repository@umich.edu. 


\section{Government Misconduct and Convicting the Innocent}

The Role of Prosecutors, Police and Other Law Enforcement

Samuel R. Gross, Senior Editor, srgross@umich.edu Maurice J. Possley, Senior Researcher

Kaitlin Jackson Roll, Research Scholar (2014-2016)

Klara Huber Stephens, Denise Foderaro Research Scholar (2016-2020)

NATIONAL REGISTRY OF EXONERATIONS

SEPTEMBER 1, 2020 


\section{For Denise Foderaro and Frank Quattrone}

Government Misconduct and Convicting the Innocent The Role of Prosecutors, Police and Other Law Enforcement

Page ii • National Registry of Exonerations • September 1, 2020 


\section{Preface}

This is a report about the role of official misconduct in the conviction of innocent people. We discuss cases that are listed in the National Registry of Exonerations, an ongoing online archive that includes all known exonerations in the United States since 1989, 2,663 as of this writing. This Report describes official misconduct in the first 2,400 exonerations in the Registry, those posted by February 27, 2019.

In general, we classify a case as an "exoneration" if a person who was convicted of a crime is officially and completely cleared based on new evidence of innocence. A more detailed definition appears here.

The Report is limited to misconduct by government officials that contributed to the false convictions of defendants who were later exonerated-misconduct that distorts the evidence used to determine guilt or innocence. Concretely, that means misconduct that produces unreliable, misleading or false evidence of guilt, or that conceals, distorts or undercuts true evidence of innocence.

Three years ago, the Registry released a report on Race and Wrongful Convictions in the United States. We found, among other patterns, that Black people who were convicted of murder were about 50\% more likely to be innocent than other convicted murderers, and that innocent Black people were about 12 times more likely to be convicted of drug crimes than innocent white people. Some of those disparities are caused by the type of misconduct we study here and some are not.

Misconduct in obtaining and presenting evidence contributes substantially to the racial disparity in murder exonerations, as we will see. On the other hand, the huge disparity in drug exonerations primarily reflects a type of misconduct we don't cover in this Report-racial discrimination in choosing which people to stop or search for drugs, what is commonly called "racial profiling."

The Report describes many varieties of misconduct in investigations and prosecutions. Some are always deliberate, some are rarely or never deliberate, and some may or may not be deliberate.

The Report organizes the myriad of types of misconduct into five general categories, roughly in the chronological order of a criminal case, from initial investigation to conviction: Witness Tampering; Misconduct in Interrogations of Suspects; Fabricating Evidence; Concealing Exculpatory Evidence; Misconduct at Trial.

Most of the misconduct we discuss was committed by police officers and by prosecutors. We also report misconduct by forensic analysts in a minority of cases, mostly rapes and sexual assaults, and by child welfare workers in about a quarter of child sex abuse cases.

Some major patterns we observed:

- Official misconduct contributed to the false convictions of $54 \%$ of defendants who were later exonerated. In general, the rate of misconduct is higher in more severe crimes. 
- Concealing exculpatory evidence-the most common type of misconduct-occurred in $44 \%$ of exonerations.

- Black exonerees were slightly more likely than whites to have been victims of misconduct (57\% to $52 \%$ ), but this gap is much larger among exonerations for murder ( $78 \%$ to $64 \%)$ - especially those with death sentences (87\% to 68\%) - and for drug crimes (47\% to $22 \%)$.

- Police officers committed misconduct in $35 \%$ of cases. They were responsible for most of the witness tampering, misconduct in interrogation, and fabricating evidence-and a great deal of concealing exculpatory evidence and perjury at trial.

- Prosecutors committed misconduct in 30\% of the cases. Prosecutors were responsible for most of the concealing of exculpatory evidence and misconduct at trial, and a substantial amount of witness tampering.

- In state court cases, prosecutors and police committed misconduct at about the same rates, but in federal exonerations, prosecutors committed misconduct more than twice as often as police. In federal exonerations for white-collar crimes, prosecutors committed misconduct seven times as often as police.

We also examined disciplinary actions against officials who committed misconduct. These were uncommon for all types of officials, and especially so for prosecutors.

We tried to determine whether official misconduct that contributes to false convictions has become more or less frequent over the past 15 to 20 years. For most types of misconduct, we won't know for years to come, but we already see strong evidence that a few kinds of misconduct have become less common: violence and other misconduct in interrogations; abusive questioning of children in child sex abuse cases; and fraud in presenting forensic evidence. On the other hand, the number of federal white-collar exonerations with misconduct by prosecutors has been increasing.

In the last section we consider what led officials to commit misconduct. We conclude that the main causes are pervasive practices that permit or reward bad behavior, lack of resources to conduct high quality investigations and prosecutions, and ineffective leadership by those in command. We discuss a range of possible remedies, from specific rules to changes in culture, in cities, counties, states and the nation as a whole.

We present many other findings in the Report itself. The core of our data on official misconduct are available online, sortable and filterable, for others to explore; go to the "OM Tags" column here.

Samuel R. Gross

Maurice J. Possley

Kaitlin Jackson Roll

Klara Huber Stephens

September 1, 2020 


\section{Use Note:}

\section{Common terms}

It may be useful to explain some terms that we use in this Report:

Exoneration means an exoneration listed in the Registry. Every exoneration, identified by the name of the exoneree, has a page in the Registry, and is listed on our Summary View and Detailed View pages.

Known exonerations: We know that our list of exonerations is incomplete: we regularly discover cases we missed. Sometimes we specify that these are "known exonerations," more often we don't, but it's true regardless.

Misconduct in an exoneration: Strictly speaking, the practice we write about is official misconduct that contributed to a criminal conviction that was ultimately reversed by exoneration. That's a mouthful. For convenience, we often refer to it as "misconduct in the exoneration" even though the misconduct was part of the process of obtaining a conviction.

Police: Police agencies in the United States range from one-person police departments to the FBI. The titles of sworn peace officers include Patrolman, Officer, Deputy Sheriff, Trooper, Agent-and many more. We refer to all of them as "police."

\section{Links and Navigation}

(i) The report contains numerous links to pages on the website of the National Registry of Exonerations. Most are links to the stories of individual exonerees; some are links to collections of cases. In both situations, almost all links go to the current versions of the pages, not those in effect in late February 2019, when we completed the set of 2,400 exonerations that are the subject of this report. For example:

- This link goes to Ricky Jackson's page, which was last updated in May 2020. That page contains information we did not know when we completed the compilation of the dataset fifteen months earlier-and (like other summaries and data on the Registry) it may be further modified in the future.

- This link goes to a list of all exonerations with misconduct in Cook County at the time you click on it-230 as of this writing, more in months and years to comenot the 204 exonerations with official misconduct in Cook County among the 2,400 exonerations included in this Report.

(For technical reasons, a few links go to copies of Registry pages rather than live pages.)

(ii) The Executive Summary and the Table of Contents contain links that may help navigate this document. The Summary contains a list of page numbers in the form of links-like this, 2-that take you to the indicated page in the text. In the Table of Contents you can click on any part of an entry to go to the page on which that section begins. 
(iii) Each page of the text (except the first pages of major sections) includes two highlighted buttons:

Go to Executive Summary and Go to Table of Contents.

If you click on them, they will take you to the beginning of the Executive Summary and of the Table of Contents, respectively. 


\section{Acknowledgements}

We didn’t do this on our own. Not nearly. It took a couple of villages and a lot of friends.

This report was produced by the National Registry of Exonerations. The editors of the Registry were essential: Barbara O'Brien, Editor in Chief; Simon Cole, Associate Editor and Director; and Catherine Grosso, Managing Editor. They read drafts, classified cases and thought through the project with us. The Registry staff-Ken Otterbourg, Jessica Weinstock Paredes, Meghan Cousino, and Eva Nagao who left us this June-were equally essential. They identify the cases on which our work is based; research, code and write them up; and maintain the website through which the work of the Registry is available to the world. We also received invaluable support and advice from our Advisory Board, especially Denise Foderaro, Barry Scheck, and Rob Warden, co-founder of the Registry.

The core work of our work-researching, coding, checking and recoding information on official misconduct in the 2,400 cases in our database-was mostly done by a dedicated group of research assistants-some of whom also did legal research, wrote memoranda, commented on and corrected partial drafts, and provided advice at many stages. Most were students at the University of Michigan Law School-Christine Adams, Zachary Adorno, Claudia Arno, Jennifer Chun, Michael Darling, Lauren Flamang, Max Greenwald, Griffin Hardy, Caroline Howe, Connor Lang, Ginny Lee, James Millikan, Amanda Rauh-Bieri, Amanda Stephens, Jenny Stone, Julia Xin and Eric Yff-or at the Michigan State University College of Law: Nadine Kassem and Alison Swain. In addition, we received excellent contributions from two young lawyers, Marc Allen and Eli Wykell, and careful statistical analyses from Josue Guevara, starting when he was a student at Michigan, German Marquez Alcala, who works for the University of Michigan Law Library, and Valerie King, as graduate student at the Univesity of California, Irvine, and after she completed her degree.

The staff at the University of Michigan Law School was as skillful and helpful as always. In particular, Cheri Fidh corrected more errors in content and format than we can count, while Alex Lee and Richard Savitski are responsible, respectively, for the appearance and the contents of the data we are making available online with this report. At a distance, Julie Smith designed the appearance of the report, and Margot Friedman worked tirelessly to present it to the world.

The staff of the Innocence Project was unfailingly helpful, including especially Barry Scheck and Rebecca Brown, who answered questions, provided information, read drafts, and suggested additions. Elizabeth Webster, formerly of the Innocence Project, spent a summer helping us devise our initial coding system. And our dear friends in Ann Arbor, Phoebe Ellsworth and Alexandra Gross, read partial and full drafts of this report repeatedly over several years, made countless corrections and suggestions, and sustained our spirits.

The Registry, and this project in particular, depend on generous financial support from many individuals and organizations. We are particularly grateful to James and Martha Newkirk, and to Denise Foderaro and Frank Quattrone, who encouraged and supported our work since its inception, in many ways.

Government Misconduct and Convicting the Innocent The Role of Prosecutors, Police and Other Law Enforcement

Page vii • National Registry of Exonerations • September 1, 2020 
The Registry is a joint project of three universities. We are fortunate to have had the support of the University of Michigan Law School, our original home for several years; the Michigan State University College of Law, which took us on four years ago; and the Newkirk Center for Science \& Society at the School of Social Ecology of the University of California, Irvine, which has been our main home since 2016. 


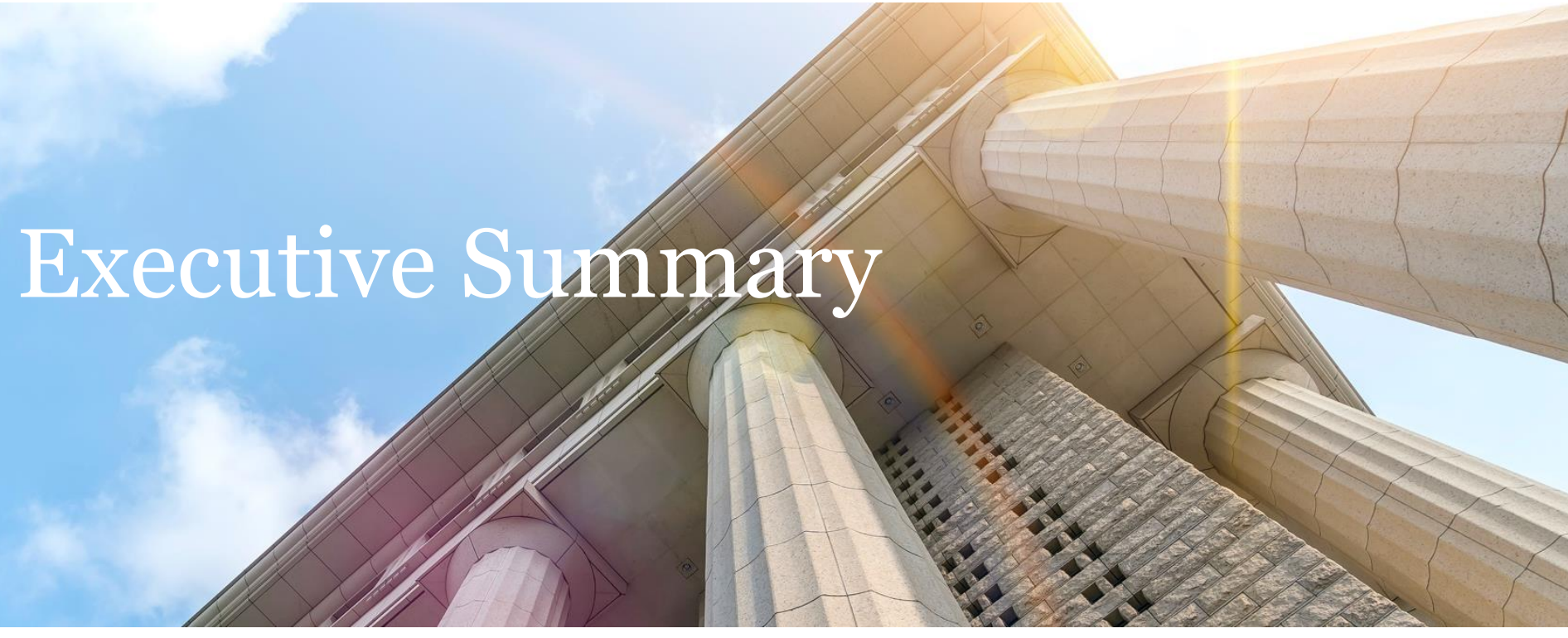

Page

I. Introduction

$\underline{1}$

II. Background

3

Misconduct by law enforcement has received a great deal of attention as a result of the Black Lives Matter movement, which has focused on racial discrimination and violence by police officers. We study a different (but overlapping) type of behavior: misconduct that distorts evidence in criminal cases and leads to convictions of innocent people.

There is a dearth of prior systematic research on police misconduct that contributes to false convictions.

Prosecutorial misconduct has attracted a good deal of attention in the past decade, primarily concealing exculpatory evidence. Several studies have found thousands of criminal cases in which courts or other agencies determined that prosecutors committed misconduct, but very few were disciplined for it.

Our database, the National Registry of Exonerations, is an ever-changing

public archive. We define "exoneration" by the conduct of public officials, and use only non-confidential data. We list all exonerations we can find, add new cases regularly, and modify our postings on old cases as we get more information or refine or inquiries.

This unique database enables us to examine all exonerations-with data from multiple sources-to identify many cases of misconduct that cannot be found in official decisions, and to begin to describe the causes and effects of that misconduct.

We cannot, however, estimate rates of misconduct in all criminal cases; and even among exonerations we miss a great deal of official misconduct that remains hidden. 
Page

We do not systematically examine misconduct by criminal defense attorneys or by judges. That's unfortunate, especially for ineffective legal assistance by defense lawyers, which is probably a major contributor to convictions of innocent defendants. The main reason is that we do not have data that would enable us to speak to those issues.

\section{The Frequency of Official Misconduct}

$\underline{11}$

In $54 \%$ of exonerations, official misconduct contributed to the false convictions; usually more than one type of misconduct. Overall, male exonerees and Black exonerees were modestly more likely to experience misconduct (with some larger differences by race for a few particular crimes).

30\% of exonerations include misconduct by prosecutors, 35\% misconduct by police, $3 \%$ by forensic analysts, and $2 \%$ by child welfare workers.

The overall rate of misconduct varies by crime, from $\mathbf{7 2 \%}$ in murder cases to $\mathbf{3 2 \%}$ for most non-violent crimes. For most crimes, the rates of misconduct for prosecutors and police are comparable. However:

- For drug crimes, the rate of police misconduct is nearly four times the rate of misconduct for prosecutors.

- In white-collar exonerations, prosecutorial misconduct is more than five times as frequent as misconduct by police. This gap is entirely due to the extremely high rate of misconduct by federal white-collar prosecutors.

We only count misconduct that contributed to the exonerees' false convictions by generating false evidence of guilt or concealing true evidence of innocence. We don't count misconduct that can't produce false evidence-for example, police brutality that was not part of an interrogation-or failed attempts to produce false evidence, such as torturing a suspect who does not confess.

Violent felonies account for nearly $\mathbf{8 0 \%}$ of exonerations. Misconduct is generally more common the more extreme the violence, ranging from $\mathbf{3 8 \%}$ and $\mathbf{3 9 \%}$ for robbery and sexual assault cases to $\mathbf{7 2 \%}$ for exonerations from death sentences. These numbers reflect both higher rates of official misconduct in the most serious crimes, and more diligent post-conviction reinvestigations.

Drug crimes make up more than $\mathbf{6 0 \%}$ of exonerations for non-violent crimes. Twothirds of them occurred in two very different local clusters: 
- In Chicago, 66 convicted drug offenders were exonerated after it was shown that officers under the command of a corrupt police sergeant or his subordinates $\quad \underline{21}$ planted evidence on them. All of those cases involved police misconduct.

- In Harris County, Texas (Houston), 149 defendants who pled guilty to drug crimes were exonerated after lab tests found no illegal drugs in the materials $\underline{24}$ seized from them. Only $\mathbf{3} \%$ of those cases involved misconduct.

White-collar crimes-the second largest group of exonerations for non-violent offenses-are primarily federal cases with a very high rate of prosecutorial misconduct.

About 8o\% of criminal convictions in the United States are misdemeanors, but only about 4\% of exonerations, and two-thirds of those are Harris County drug crime guilty plea cases. The remaining sliver of misdemeanor exonerations-about $\mathbf{1 \%}$ of the $\quad \underline{26}$ total-have a high rate of official misconduct, $\mathbf{5 8 \%}$.

Overall, exonerations of Black defendants have a slightly higher rate of misconduct than those of white defendants, $\mathbf{5 7 \%}$ to $52 \%$. But the differences are greater for murder cases (78\% to $64 \%)$ - especially those with death sentences (87\% to $68 \%)-\quad 28$ and drug crime exonerations (47\% to $22 \%)$.

Almost all the official misconduct we have identified falls into five general categories that we discuss in detail in the sections that follow:

1. Witness tampering occurred in about $\mathbf{1 7 \%}$ of exonerations.

2. Misconduct in interrogations occurred in $\mathbf{5 7 \%}$ of all exonerations with false confessions, or about $7 \%$ of all cases.

3. Fabricating evidence happened in about $\mathbf{1 0 \%}$ of cases, in three forms: Forensic fraud-in $\mathbf{3 \%}$ of exonerations, police officers or forensic analysts lied about forensic evidence. Fake crimes-in 4\% of exonerations, police planted drugs or guns on innocent suspects, or lied and said the suspects had assaulted them. Fictitious confessions-in about $\mathbf{2 \%}$ of exonerations, officers fabricated confessions from defendants who did not confess.

4. Concealing exculpatory evidence is the most common type of official misconduct we found. It occurred in $\mathbf{4 4 \%}$ of all exonerations.

5. Misconduct at trial occurred in about $23 \%$ of exonerations, about evenly divided between perjury by law enforcement officers, 13\%, and trial misconduct by prosecutors, 14\% (with some overlap). 
Misconduct in interrogations occurred overwhelmingly in murder exonerations; concealing exculpatory evidence and misconduct at trial were most common in murder cases, followed by white-collar crimes; witness tampering was slightly more common among exonerations for child sex abuse exonerations than for murder; and fabricating evidence was several times more common among exonerations for drug crimes than for any other crime.

Witness tampering occurs when a law enforcement officer tricks, persuades or forces a witness to testify falsely against the defendant. The officer need not know that the witnesses is testifying falsely as long as the officer does not care whether the witness is telling the truth.

Witness tampering occurred in $\mathbf{1 7 \%}$ of exonerations. In $\mathbf{5 \%}$, witnesses were forced to give false testimony by threats, in $\mathbf{1 3} \%$ they were manipulated into doing so without threats. (1\% of cases included both types of tampering.)

Witness tampering occurred most often in child sex abuse cases, $\mathbf{2 8 \%}$, and murder cases, 23\%. Police participated in witness tampering in $\mathbf{8 0 \%}$ of cases where it occurred, prosecutors in $\mathbf{3 1 \%}$ and child welfare workers in $\mathbf{1 4 \%}$.

About four-fifths of witness tampering falls into one of three categories:

1. Procuring false testimony-inducing a witness to testify to facts the officer or prosecutor knows the witness did not perceive.

2. Tainted identifications -inducing a witness to identify a suspect at an identification procedure, whether or not the witness recognizes the suspect.

3. Improper questioning of a child victim-repeated, insistent and suggestive questioning of a child by officials who will not allow the child to deny that $\mathrm{s} /$ he was a victim of sex abuse.

Procuring false testimony, with or without threats, means obtaining testimony that both law enforcement and the witness know is false. It occurred in $6 \%$ of exonerations, two thirds of them murder cases. Police were involved about twice as often as prosecutors.

A suggestive identification procedure-for example, giving a witness a single picture of a suspect to identify-may easily cause misidentifications, but that alone is not misconduct. A tainted identification occurs when an officer directly or indirectly "tells" a witness who to identify as the criminal.

Tainted identifications occurred in about 6\% of exonerations. Three quarters were murder and sexual assault cases; almost all were obtained by police. 
- In $\mathbf{8 0 \%}$ of murder cases with tainted identifications, at least one witness deliberately misidentified the exoneree; many were forced to do so.

- In all but one sexual assault exonerations, victims or other witnesses were persuaded or tricked into misidentifying the exonerees by mistake; in one case, the identification was produced by threats.

Improper questioning of a child victim occurred in about a quarter of child sex abuse exonerations, primarily cases from the epidemic of child sex abuse hysteria prosecutions in the early 1980 s to the late 1990 s.

- Police participated in improper questioning of child victims $\mathbf{8 5 \%}$ of the time, and child welfare workers did so in $\mathbf{7 1 \%}$ of the cases. Most of the children were questioned by more than one type of official.

- Some children who eventually testified against exonerees came to believe their accusations; others have said that they knew that they were lying.

In 12\% of known exonerations-mostly murder cases-convictions were based on false confessions by the exonerees. $\mathbf{5 7 \%}$ of false confessions were obtained by misconduct in interrogations.

Misconduct in interrogations is defined (if not clearly) by the Supreme Court. Beginning in the 1940s, the Court developed an increasingly strong prohibition against violence in interrogations. Otherwise, an interrogation violates due process of law if under the "totality of the circumstances" it is deemed so coercive that the resulting confession is "involuntary."

False confessions are far more common in Chicago than elsewhere. In the rest of the country, $\mathbf{1 0 \%}$ of all exonerations and $\mathbf{1 8 \%}$ of murder exonerations included false confessions; in Chicago the comparable figures are $\mathbf{3 3 \%}$ and $\mathbf{5 4 \%}$.

The same is true of misconduct in interrogations: $\mathbf{7 7 \%}$ of false confessions in Chicago were obtained by misconduct, compared to $49 \%$ elsewhere.

Actual or threatened violence was used in $\mathbf{6 4 \%}$ of interrogations with misconduct $-36 \%$ of all exonerations with false confessions-as often as all other forms of misconduct in interrogations combined.

The concentration of violence in interrogations in Chicago is particularly stark. Violence was used to obtain $\mathbf{6 9 \%}$ of false confessions in exonerations in Chicago, but only $24 \%$ elsewhere. Half of all exonerations in the country with false confessions that were obtained by violence are from Chicago. 
Much of the violence in interrogations in Chicago was due to a systematic program of torture of Black suspects in the 1970 s and 8os by Chicago Police Commander Jon Burge and his subordinates (see Section XII).

Some lies, promises and threats in interrogations are permitted, and some are prohibited. The distinction can be elusive. Other than violence, most misconduct in interrogations consisted of prohibited lies, promises or threats.

Interrogators are allowed to lie about the facts of the investigation ("we found your fingerprints") but not about the law ("you'll get sentenced to death"). They may make vague promises ("if you confess, we can help you"), but not specific ones they can't keep ("if you confess, the DA won't ask for the death penalty"). In $\mathbf{2 0 \%}$ of exonerations with false confessions, the police lied about the law or promised outcomes they couldn't deliver.

Police may threaten to arrest a suspect who does not confess-an act within their power-and prosecutors may threaten to prosecute one who does not cooperate. But threats against third parties-e.g., to arrest a spouse or child of the suspect, or to remove minor children from her home-are prohibited. Third-party threats were used in $\mathbf{8 \%}$ of exonerations with false confessions.

Several permitted interrogation practices also contribute to false confessions:

- Permissible promises and threats.

- Lying about the investigation.

- Telling the suspect details of the crime (which makes it hard to separate true confessions from false ones generated by the police).

- Interrogating a juvenile without a parent or guardian present.

ne or more of these practices contributed to 70\% of false confessions: $79 \%$ of those obtained with misconduct and $\mathbf{5 7 \%}$ of those obtained without it.

Confessions by actual or possible codefendants of the exonerees falsely implicated exonerees in about $\mathbf{1 3 \%}$ of cases.

Many codefendants voluntarily confessed and implicated exonerees, usually to shift some blame away from themselves. About a third of codefendant confessions that contributed to false convictions were obtained by the same types of misconduct that produced most false confessions by the exonerees themselves.

In a third of exonerations with codefendant confessions, the exoneree also confessed; in the rest, the exoneree did not. The net effect is that all false confessions-by codefendants as well as by exonerees themselves-contributed to the convictions in $\mathbf{2 1 \%}$ of exonerations. 
As with false confessions by exonerees, false codefendant confessions that helped convict exonerees were concentrated in murder cases, and in Chicago.

In $\mathbf{1 0 \%}$ of exonerations, officers falsely reported that they examined forensic evidence that proved (or failed to disprove) the defendants' guilt, saw the defendants commit crimes that did not occur, or witnessed confessions by defendants who did not confess.

Forensic fraud-the deliberate falsification of forensic evidence to help convict a defendant-occurred in $\mathbf{3 \%}$ of exonerations.

- Forensic fraud is a form of intentional misconduct. We do not count a larger set of cases with forensic evidence that was (as far as we know) unintentionally mistaken, misleading, or invalid.

- We only count forensic fraud by law enforcement officers, usually forensic examiners at police crime labs or other state-run labs.

- There are many types of forensic fraud, but these are the most common:

1. In more than a third of the cases, analysts reported that the defendant's hair, saliva, blood, semen, tooth marks, etc., matched or were consistent with those found at the crime scene, when in fact testing had shown the opposite.

2. In about a quarter of the cases, forensic witnesses reported that the defendants might have been the source of crime-scene blood, semen or fingerprints, after forensic tests that showed that was impossible.

- A third of forensic fraud cases involve repeat offenders, possibly because they are more likely than other wrongdoers to eventually get caught, after which $\quad \underline{67}$ many of their prior cases are reexamined.

Fake crimes were fabricated by police in about $\mathbf{5 \%}$ of exonerations:

- In about $4 \%$, police planted evidence at the scene of the crime and claimed to have found it there. In all but a few cases, they planted illegal drugs-especially $\underline{68}$ in a cluster in Chicago (see above, Section III.3.c.i).

- In about 1\%, officers falsely claimed that the defendants assaulted them, usually to cover up their own violence against the same defendants. 
Fabricated confessions: In about $2 \%$ of exonerations, police made up confessions from exonerees who did not confess.

- In several cases, police had exonerees sign documents they did not or could not read, which later turned out to be confessions. In most cases, they lied and 70 said the exonerees made unrecorded oral confessions.

- As usual for false confessions, fabricated confessions were more likely in Chicago than elsewhere, but by a modest amount, $16 \%$ to $11 \%$.

Concealing exculpatory evidence contributed to the convictions of $44 \%$ of exonerees, more than any other type of official misconduct we know of.

The legal duty to disclose exculpatory evidence has multiple bases:

- In Brady v. Maryland, in 1963, the Supreme Court announced the 'Brady rule': "[S] uppression by the prosecution of evidence favorable to the accused... violate[s] due process where the evidence is material either to guilt or to punishment."

- Brady only applies if the concealed evidence is "material"-which, in this context, means that the outcome of the trial would likely have been different if that evidence had been known. This requirement has been widely criticized as incoherent, inconsistent and unadministrable.

- In addition, rules of professional responsibility and pretrial discovery that govern criminal cases also require the prosecution to disclose all exculpatory evidence, regardless of "materiality."

- We apply these procedural and ethical rules-and classify hiding evidence as misconduct regardless of "materiality"-because they prescribe correct conduct rather than define a violation of the constitution. (Plus, we too could not classify "materiality" consistently if we tried.)

The rate of concealing exculpatory evidence varies by crime, from $\mathbf{6 1 \%}$ for murder to $27 \%$ in child sex abuse cases. It is so common and widespread that it happened in $82 \%$ of all exonerations with any official misconduct.

Prosecutors concealed exculpatory evidence in $73 \%$ of cases in which it occurred. That's not surprising, since prosecutors have the duty to disclose that evidence to the defense. We only count other officials as responsible if (as far as we know) prosecutors were ignorant of the evidence. 
Page

Police concealed exculpatory evidence in $\mathbf{3 3 \%}$ of cases where it occurred (including cases with concealing by more than one type of official), and forensic analysts did so in 6\%. In some portion of those exonerations, prosecutors did know about the concealed evidence, but we have no record of that knowledge.

As far as we know, only $\mathbf{1 3} \%$ included concealed physical objects-clothing, weapons, etc. This gap may in part reflect how effectively objects can be destroyed or hidden, but information may linger in electronic or physical files, or the memories of people.

In $63 \%$ of cases with concealed exculpatory evidence, substantive evidence of the exonerees' innocence was hidden-evidence that in itself helps prove the defendant's innocence, such as an eyewitness who named another person as the criminal.

In $\mathbf{8 0} \%$ of such cases, impeachment evidence that undermined testimony by prosecution witnesses was concealed-for example, evidence that a witness who identified the exoneree as a murderer told his brother he never saw the killing.

In half the exonerations with concealed exculpatory evidence, both substantive and impeachment evidence were hidden. Often, a single item of evidence serves both functions. "Substantive" evidence may sound more important, but concealing impeachment evidence that eviscerates the credibility of a critical prosecution witness can be devastating to an innocent defendant.

Predictably, law enforcement officials usually conceal their own misconduct. That's misconduct in itself, derivative concealment. For example, it's misconduct for an officer to plant drugs on a suspect, and it's a separate act of misconduct to conceal the officer's knowledge that the suspect is innocent.

Evidence of other official misconduct was concealed in $\mathbf{2 6 \%}$ of all exonerations, over half of exonerations with any concealed exculpatory evidence.

A large variety of types of exculpatory evidence were concealed, but most fall into several categories.

\section{Impeachment evidence:}

- Incentives to testify against the exonerees were concealed in $\mathbf{2 1 \%}$ of exonerations, most often deals on criminal charges against the witnesses.

- Inconsistent statements by prosecution witnesses that contradicted their testimony were concealed in $\mathbf{1 4 \%}$ of exonerations.

- Criminal records and histories of dishonesty of witnesses for the state were concealed in $\mathbf{4 \%}$ of exonerations. 
- Exculpatory forensic tests were concealed in $\mathbf{6 \%}$ of exonerations, including many that conclusively established the exonerees' innocence.

- Alternative suspects were concealed in $\mathbf{1 2 \%}$ of all exonerations-20\% of murder exonerations and $\mathbf{6 \%}$ of other cases.

- Exclusions by an eyewitness-evidence that an eyewitness said the exoneree is not the criminal-was concealed in $\mathbf{2 \%}$ of exonerations.

- Alibi evidence was concealed in $\mathbf{1 \%}$ of exonerations.

- Evidence that no crime was committed was concealed in $6 \%$ of exonerations, mostly cases where police concealed the fact that they themselves framed the defendants.

At least 95\% of criminal convictions in the United States are obtained by guilty pleas rather than trial verdicts, but $\mathbf{8 0 \%}$ of exonerations in the Registry followed conviction at trial. About $\mathbf{2 8 \%}$ of those trials (23\% of all exonerations) included official misconduct in court.

- Perjury by all law enforcement officials occurred in $14 \%$ of the trials at which exonerees were convicted, or 13\% of all exonerations (including those after guilty pleas). In about a quarter of those cases, officials lied about forensic testing, or about things the officials themselves claimed to have witnessed the exonerees do or say. (See above, Section VI.)

- Perjury by police officers occurred in 11\% of trials of exonerees. In $9 \%$ of those trials ( $7 \%$ of all exonerations), officers lied about information obtained from others.

- Most often, police lied about the conduct of the investigations: what a witness had said, whether or how a lineup was conducted, etc. The most common subject of police perjury was the conduct of interrogations at which innocent defendants confessed. 
- We miss a great deal of police perjury. We rarely have access to transcripts or other detailed information about trial testimony, so we only $\quad 98$ learn about perjury at trial if it becomes a conspicuous issue.

Trial Misconduct by Prosecutors

* In 1959, the Supreme Court held that a prosecutor has a constitutional obligation to correct perjury by a state witness even $\quad 99$ if she did not herself offer the false testimony.

* Prosecutors permitted perjury to go uncorrected in $\mathbf{8 \%}$ of exonerations. In most cases, the perjury was by civilian witnesses. The most common lies were about favorable treatment the witnesses 99 receive in pending criminal cases of their own.

* It is misconduct, and punishable as contempt of court, for a lawyer to lie in court, whether or not the lawyer in under oath.

We know that prosecutors lied in court in $\mathbf{4 \%}$ of exonerations. The real rate may be higher since we only count cases with clear evidence $\quad \underline{102}$ that prosecutors made statements they knew were false.

* About half of lies by prosecutors were made in closing argument. A common pattern is to repeat and affirm perjury by a witness that the prosecutor knew about but failed to correct-for example, a lie by a witness who claimed to have no deal with the prosecutor.

- Improper Statements in Closing Argument or Cross-examination

Prosecutors also commit misconduct at trial without lying, usually in closing arguments or in questions on cross-examination.

- Prosecutors made improper closing arguments (without lying) in 3\% of exonerations, ranging from statements that the prosecutor "knows" 104 the exoneree is guilty to outright appeals to bigotry. 
Page

Prosecutors asked impermissible questions on cross-examination in $\mathbf{1 \%}$ of exonerations.

$\underline{106}$

- Both forms of misconduct are undoubtedly much more common than we know. They are only visible if the defense objects at the time, 104 and lawyers often fail to do so, intentionally or by neglect.

Federal crimes are a small and unrepresentative minority of all criminal cases in the United States. They generate about $\mathbf{6 \%}$ of convictions, heavily skewed to immigration, 108 drug and white-collar crimes.

Federal exonerations are a comparably small minority of all exonerations, and equally skewed: $\mathbf{4 1 \%}$ are white-collar crimes, and another half are about evenly split $\underline{108}$ between drug and violent crimes.

The overall rate of official misconduct is somewhat higher in federal exonerations than in state cases, $61 \%$ compared to $54 \%$.

Most misconduct in federal exonerations was committed by prosecutors, $52 \%$ compared to $\mathbf{2 9 \%}$ in state cases.

Federal prosecutors committed misconduct in exonerations more than twice as often as police (52\% to $\mathbf{2 0 \%}$ ), while state prosecutors committed misconduct less often than police (29\% to $\mathbf{3 6 \%}$ ).

Federal white-collar exonerations have striking similarities to murder exonerations under state law. They are the most common types of exonerations in their respective courts; many are big-ticket cases-expensive, long-running, conspicuous; they have the highest rates of misconduct for exonerations in those courts, $\mathbf{6 5} \%$ for federal white-collar crimes, $\mathbf{7 2 \%}$ for state-court murders.

In federal white-collar exonerations, prosecutors committed misconduct more than 7 times as often as police, $65 \%$ to $9 \%$; every federal white-collar exoneration with any official misconduct included misconduct by a prosecutor.

Federal white-collar cases have both the highest rate of misconduct by prosecutors and the lowest rate of misconduct by police of exonerations in any crime category. 
Federal white-collar prosecutors seem to play a more dominant role in cases that lead to exonerations than state prosecutors. They have more resources, and are more likely to take the lead in the investigations. That role may reduce police misconduct-but not misconduct by the prosecutors themselves.

In $\mathbf{1 7 \%}$ of exonerations with official misconduct, we know that some form of discipline was imposed on officials who participated in that misconduct.

Many officials who were disciplined committed misconduct in several or many exonerations, but formal discipline was limited to one, or was imposed in a separate case. Chicago Police Commander Jon Burge, for example, was sentenced to prison for lying about the torture program he ran. We count that as discipline in all 19 cases in which he or those he commanded abused the exonerees. In $70 \%$ of exonerations with discipline, it was imposed for general patterns of behavior or in cases other than the specific ones at hand.

Discipline may be imposed by three sets of authorities: employment discipline by the agencies that employ the misbehaving officials; professional discipline by regulatory bodies that certify or license their professions (this category includes a few instances of courtroom discipline of prosecutors by judges); and criminal discipline, convictions by courts for misconduct that violates criminal laws.

- Prosecutors are hardly ever disciplined for misconduct that contributes to false convictions. We know of some discipline for prosecutors in $\mathbf{4 \%}$ of exonerations with prosecutorial misconduct. In most of those cases, the discipline was comparatively mild.

- Eleven prosecutors were disciplined by the offices that employed them, but just two were fired (and four resigned or retired); 14 were disciplined by bar authorities or courts, but only three were disbarred. Only two prosecutors have been convicted of crimes for misconduct in exonerations, both in notorious cases, and both received nominal sentences.

- Police officers were disciplined in $\mathbf{1 9 \%}$ of exonerations with police misconduct, about five times the rate for prosecutors. 
- In almost $80 \%$ of these cases, officers were convicted of crimes; in $\mathbf{2 0} \%$ they were disciplined by the police forces for which they worked. We know of no professional discipline of police officers.

- In 127 exonerations, police officers who committed misconduct were convicted of crimes for misconduct of the sort they committed in those casesbut not 127 separate officers. As we explained, the conviction of a single serial offender may count as discipline in many cases.

- Even so, at least 30 officers were convicted of crimes (compared to two prosecutors) and some received long prison sentences.

- Disciplinary records of police officers are often concealed by their employers, unions, and professional agencies. As a result, we have no doubt missed cases of employment and professional discipline of police.

\section{Disciplining Forensic Analysts}

- Forensic analysts were disciplined in $\mathbf{4 7 \%}$ of exonerations in which their misconduct was discovered, a much higher rate than prosecutors or police.

Four-fifths of them were disciplined by their employers, a fifth by professional agencies, and a few were convicted of crimes.

- As with police, several analysts who were disciplined were repeat offenders, each of whom participated in multiple cases. We know of 35 exonerations with discipline for forensic misconduct, but only 13 separate analysts were punished, six of whom accounted for $80 \%$ of the cases.

\section{Changes in Official Misconduct over Time}

It is difficult to detect decreases in misconduct in exonerations because of the long time lag from conviction (the last date for occurrence of misconduct) to exoneration (the earliest date when the misconduct can be added to our data).

For example, there were six times more exonerations with misconduct in murder convictions in the 16 years from 1987 through 2002 than in the 16 years from 2003 through 2018-but because the average time to exoneration for such cases is $\mathbf{1 7}$ years, more cases from the later period will continue to emerge for years.

In three contexts, official misconduct decreased so sharply that we believe the decline is real despite the difficulty of identifying decreases:

- Improper questioning of child victims all but stopped after the end of the child sex abuse hysteria epidemic that ran its course in the late 1990 s. 
- Misconduct in interrogations, especially violence, has dropped to a small fraction of what we saw for convictions before 2003.

- Forensic fraud has declined sharply in all exonerations from convictions since 2003 , and among those with forensic evidence problems.

On the other hand, the rate of federal white-collar crime exonerations with official misconduct has doubled among exonerations for convictions since 2003.

- Increases in misconduct-unlike decreases-are not hard to spot. In fact, since more exonerations in recent cases with misconduct will continue to occur, $\quad \underline{131}$ the size of an observed increase will go up over time.

We address this question by examining the conduct of the officials who committed or permitted misconduct that led to many false convictions.

We conclude that the main causes are systemic: pervasive practices that permit or reward bad behavior; lack of resources to train, supervise and conduct high quality investigations and prosecutions; and ineffective leadership by police commanders, crime lab directors and chief prosecutors.

- Ken Anderson, was the district attorney of Williamson County, Texas, who prosecuted Michael Morton for the murder of his wife, and obtained a life sentence in 1987. Anderson concealed potent exculpatory evidence that could have cleared Morton and led to the real killer-who killed another woman in 1988. Morton was exonerated by DNA in 2012.

* Why did Anderson conceal this evidence? Our best guess is that he believed Morton was guilty, paid little attention to evidence to the contrary-and concealed that evidence because that was his regular practice, it made winning easier, and no one had stopped him before.

* Anderson set the tone for his office. We know that one subordinate followed Anderson's lead and concealed evidence to convict an innocent defendant. There were probably others. 
- Richard M. Daley was chief prosecutor in Chicago in 1982 when he received a detailed report of torture of a murder suspect by then Chicago Police Lieutenant Jon Burge, who ran a systematic program of torturing suspects, mostly Black men, in the1970s and '80s. Daley ignored it, and his office continued to use confessions that Burge obtained by torture.

* Why did Jon Burge act as he did? Sadistic racists exist, and some become police officers. The real question is why he was not stopped, 138 given that many people-including Daley-knew what he was up to.

* Burge's superior in the police department could also have stopped him, but Daley had more power. He could have stopped using confessions obtained by torture, and he could have prosecuted Burge and his men for numerous violent felonies-but he didn't.

- Why was Burge given free rein? Most likely, Daley and others thought the defendants were guilty, wanted murder convictions, didn't worry about the means-and didn't mind the torture of Black men they believed were murderers.

- Joyce Gilchrist was fired as a supervisor of the Oklahoma City Police Laboratory in 2001, after 16 years at that lab. By then, Gilchrist was known to have committed forensic fraud in several cases. That count has grown to dozens of forensic fraud cases, including six exonerations.

* Why did Gilchrist pursue a career in forensic fraud? It made her a star. She received a citation from the police department, a commendation from the district attorney, an early promotion, and was named Civilian Police Employee of the Year.

Why were police and prosecutors so enthusiastic about Gilchrist? They were warned about her, and some thought her results were too good to be true, but she got convictions other analysts couldn't-so they used her.

- Officers Iannotto, Palmer, Pecorale, Martin, Visconti and Bishop, and Detective Massanova all participated in the investigation of a fatal shooting in New York in November 1990. They soon identified an innocent suspect and brought him to the scene-in handcuffs and wearing a jacket turned inside out to resemble the shooter's jacket-where several witnesses urged each other to identify him. The next day they put the disheveled suspect in a lineup with well-groomed police cadets, and he was misidentified again. 
Why did these officers conduct what an appellate court later describe as "a series of identifications [that] were both improper and prejudicial"? It seems to have been just routine: they thought they had the shooter, and got the evidence to convict him in the easiest, quickest manner.

We discuss possible changes in three contexts: possible Reforms that affect rules, resources, and accountability; the Local Leadership and Culture of crime labs, police forces and prosecutors' offices; and National Patterns of law enforcement, as shaped by the federal Department of Justice and by national culture.

\section{Reforms}

* Procedural rules. In response to Michael Morton's exoneration, the state legislature provided "open file" discovery in criminal cases in Texas-a procedural rule regulating conduct after evidence has been gathered. Such rules may reduce some types of misconduct, $\boldsymbol{i} f$ they are enforced.

* Evidence-gathering rules specify, for example, how a lineup should be run, or that interrogations must be recorded. They directly improve the quality of investigations; they may also prevent misconduct in investigations more effectively than procedural rules-if they are obeyed.

Resources. In 1992, New York had 2,000 plus murders; in 2018, a wealthier city had 287. Lack of resources-because of huge caseloads or other reasonstempts officials to close cases by cheating, lying and concealing, and makes suspects vulnerable to misconduct, because police don't look for evidence that clears them, and overworked defense lawyers can't fill the gap.

- Accountability. Discipline for misconduct in past exonerations is too slow and uncommon to prevent much misconduct in other cases. Comparatively mild contemporaneous sanctions for low level infractions, by the agencies that employ the officials, are likely to be more effective-but that is a form of ongoing supervision that requires adequate resources. 
Page

The American system of criminal justice is run primarily by thousands of independent local prosecutors, police chiefs and other administrators. Most reforms depend on their leadership and ability to change local work cultures.

- Crime Labs in the United States are usually run by local police departments. Experts agree that only independent crime labs can eliminate conflicts of interest and provide reliable technical supervision. In 2014, after a run of disastrous errors and misconduct, Houston replaced its police lab with a highly regarded independent lab-after a costly 12-year transition.

- Police. There's wide agreement that police reform in America is hard to achieve and harder to sustain, in part because of the influence of police culture. But the reforms that receive most attention concern police authority over civilians, especially use of force and race relations. Those that concern usprocedures for conducting criminal investigations-may be easier to attain.

* Recorded interrogations are the most effective means for preventing false confessions and misconduct in interrogations. In 2002, recording was required in two states; by 2019, it was 24 states and the federal government (which had prohibited it) - a sea change that was led by numerous local police forces that adopted the reform before their states.

* Improved eyewitness identification procedures prevent both false convictions and misconduct in identification procedures. By 2020, 31 states had reformed their identification practices in some manner. As with recorded interrogations, these statewide reforms were adopted after hundreds, if not thousands, of local police departments did so on their own.

- Prosecutors. Chief local prosecutors are the most powerful actors in our system of criminal justice. Like police chiefs, they are constrained by local culture and politics, but they have greater control over their own agencies. They also have unreviewable power to decide who to charge and for what crimes, and effectively control the punishments most convicted criminals receive.

- A chief prosecutor can prevent misconduct that causes false convictions in many ways: order deputies to follow correct procedures; discipline those who commit misconduct; drop (or not file) cases tainted by misconduct; prosecute officials who abuse witnesses or suspects or obstruct justice; reinvestigate past convictions of defendants who might be innocent. 
- In the past dozen years, more than 60 local prosecutors, many in major cities, have created Conviction Integrity Units (CIUs) that helped exonerate hundreds of innocent defendants. Exonerations mostly occur long after convictions, but may deter some misconduct all the same.

- Since 2014, several progressive prosecutors have been elected in major counties on platforms that include preventing false convictions. All inherited or created CIUs, and several have enacted policies to prevent future false convictions: open file discovery, and lists of police officers they will not call as witnesses because of past misconduct.

- Progressive prosecutors might also limit misconduct by police and forensic analysts by scrutinizing the evidence they present, refusing to file charges when they have doubts, and if warranted, prosecuting officials for criminal conduct.

- Progressive prosecutors have attracted substantial institutional and political opposition from police and police unions, from judges, and from other prosecutors. Their impact will depend on politics: Will those in office be reelected? Will others join their ranks? Time will tell.

Even successful reforms by crime lab directors, police chiefs and local prosecutors will, at best, turn America into a patchwork of counties with widely divergent practices, some effective at combating misconduct, some not-unless change takes place at the national level.

- The United States Department of Justice (DOJ) can foster reform, lead by example (as it did on recording interrogations in 2014), and it can take direct action to curb local police misconduct. Recently, it has retreated on all fronts.

- Reforming forensic science. For several years after 2009 DOJ played a leading role in a coordinated effort to reform the use of forensic science in the United States. That was terminated in 2017.

* Policing local police. Federal prosecutions of police officers who planted drugs on defendants have led to the dismissal of hundreds of cases, including 66 exonerations in Chicago. Before 2017, DOJ also obtained 40 decrees requiring police departments to systematically change their practices-but not since. 
* Leading prosecutors by example. Prosecutorial misconduct in federal white-collar cases is a startling example of bad practice. It's more common than in any other category of exonerations, and the $\quad 176$ number of exonerations with prosecutorial misconduct has increased in the past 18 years.

- National Culture. We discussed the culture of individual offices and departments, or particular counties. But culture also exists-and can change-at a national level.

* Questioning children. As we discussed, a nationwide practice of abusive questioning of supposed victims of child sex abuse has been abandoned since the mid-1990s.

* Forensic fraud. A similar change may be taking place with forensic fraud, at least in investigations of violent crimes. The number of known $\quad \underline{178}$ cases has decreased by more than $90 \%$ since 2003 .

\section{Violence in interrogations. In 1931, a national commission} initiated a program to eliminate violence in interrogations, which was routine across the country. By the late 1960s, beatings and torture were rare; since 2003, they've nearly disappeared. This was a major cultural change in criminal investigation in America. We could see another.

Coda: A quick summary of our thoughts on reforms. 


\section{Table of Contents}

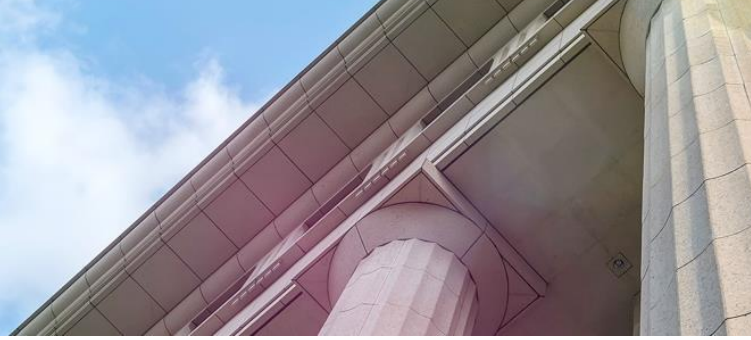

I. Introduction ................................................................ 1

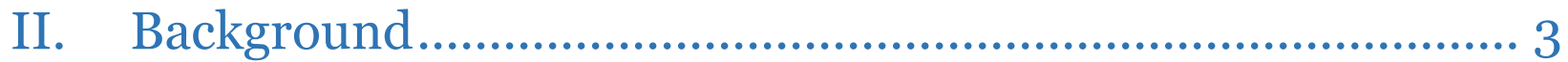

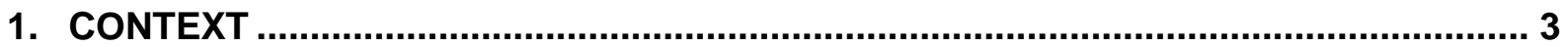

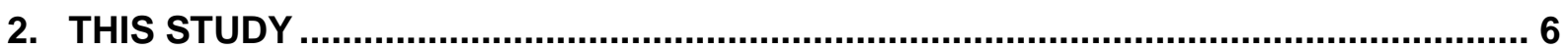

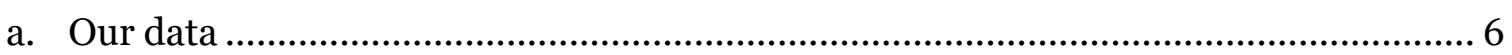

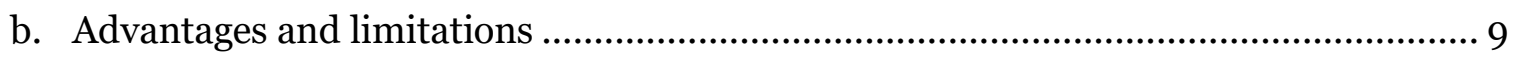

III. The Frequency of Official Misconduct ............................... 11

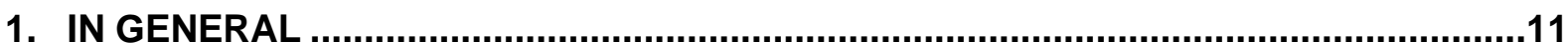

2. THE COMMISSION AND THE DISCOVERY OF MISCONDUCT ..................................13

3. MISCONDUCT BY CRIME .................................................................................15

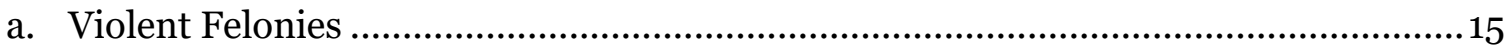

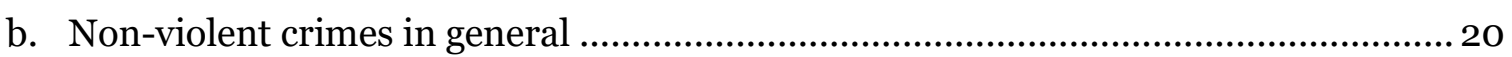

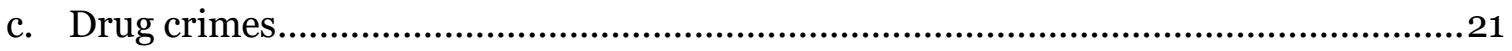

i. Group exonerations: Cook County, Illinois......................................................21

ii. Guilty pleas: Harris County, Texas .................................................................. 24

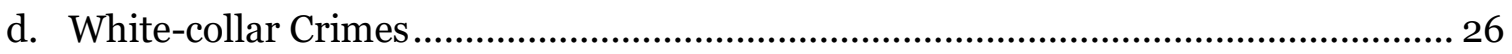

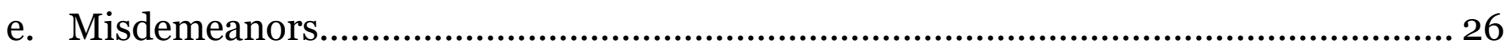

4. RACIAL PATTERNS ......................................................................................27

Government Misconduct and Convicting the Innocent The Role of Prosecutors, Police and Other Law Enforcement

Page xxix • National Registry of Exonerations • September 1, 2020 
5. CATEGORIES OF MISCONDUCT

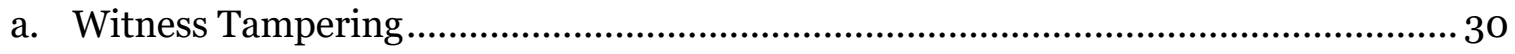

b. Misconduct in Interrogations ..................................................................................

c. Fabricated Official Evidence....................................................................................

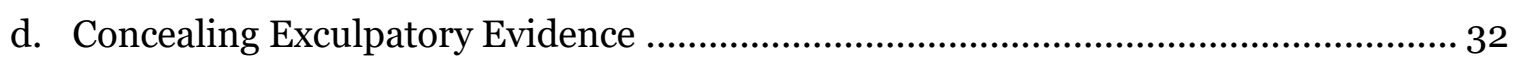

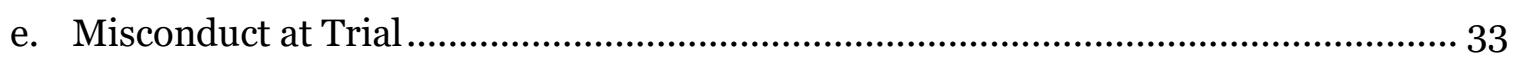

IV. Witness Tampering ................................................ 34

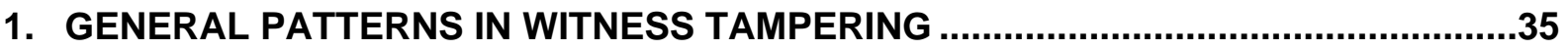

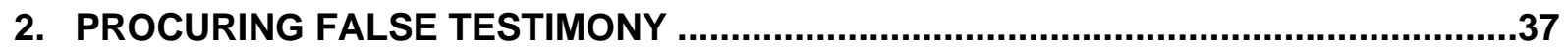

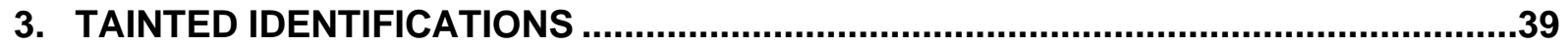

4. IMPROPER QUESTIONING OF A CHILD VICTIM.....................................................

V. Misconduct in Interrogations....................................... 45

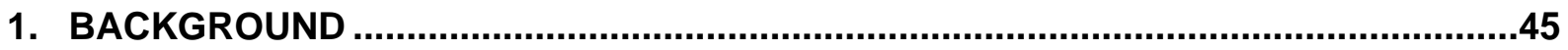

a. Misconduct and permissible interrogation techniques ................................................. 46

b. The frequency of false confessions, in Chicago and elsewhere...................................... 47

2. WHAT COUNTS AS COERCIVE MISCONDUCT IN AN

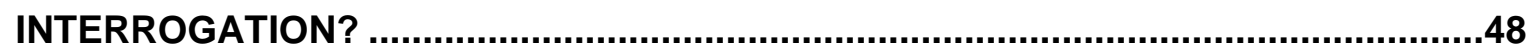

3. COERCIVE MISCONDUCT IN INTERROGATIONS THAT PRODUCE

FALSE CONFESSIONS

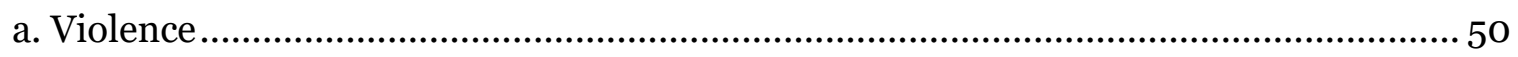

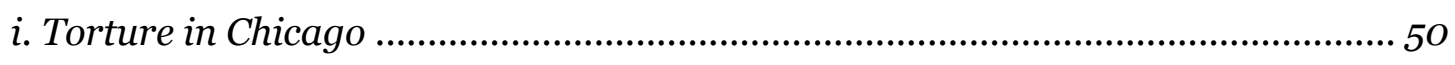

ii. Violence in interrogations of suspects with mental disabilities...............................53

b. Sham Plea Bargaining and other lies about the law …………………………........... 53

c. Threats to Third Parties ………………………………………………………….... 54

4. PERMITTED INTERROGATION PRACTICES THAT LEAD TO FALSE CONFESSIONS

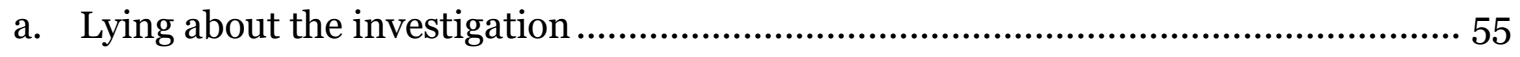

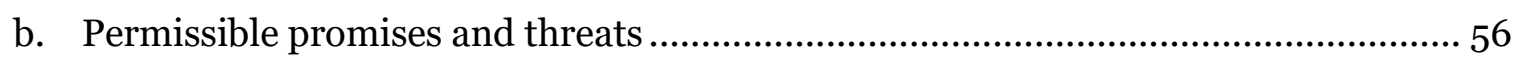

c. Feeding the suspect details of the crime......................................................................57 


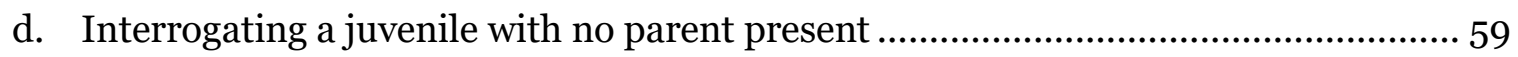

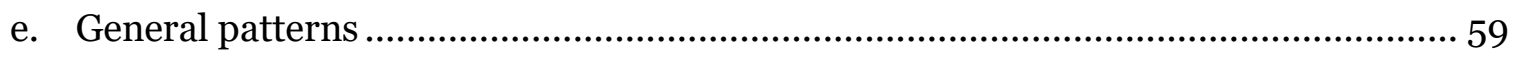

5. MISCONDUCT IN THE INTERROGATION OF CODEFENDANTS ..............................60

VI. Fabricated Official Evidence ........................................ 65

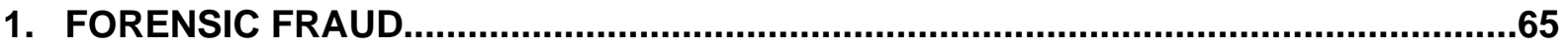

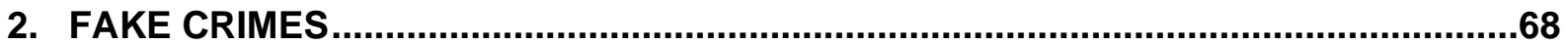

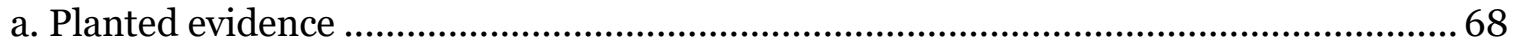

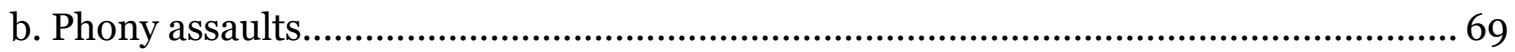

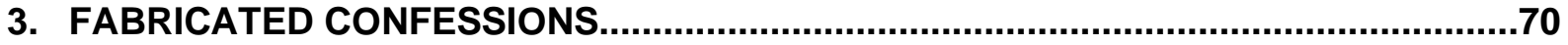

VII. Concealing Exculpatory Evidence....................................74

1. THE DUTY TO DISCLOSE EXCULPATORY EVIDENCE .........................................76

a. Brady v. Maryland and the "Materiality" Requirement............................................ 76

b. Other Legal Bases for the Duty to Disclose............................................................. 78

i. Professional Responsibility ........................................................................78

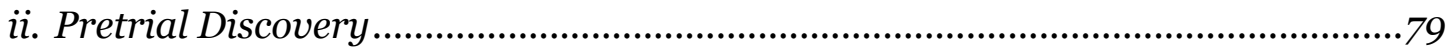

2. CONCEALING EXCULPATORY EVIDENCE, BY CRIME.........................................81

3. WHO DOES THE CONCEALING? ........................................................................81

4. WHAT WAS CONCEALED? ...............................................................................83

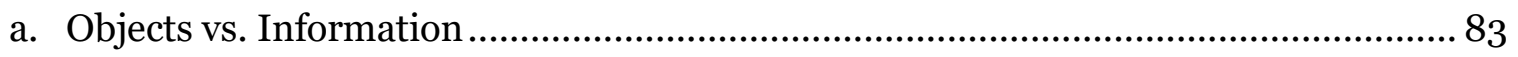

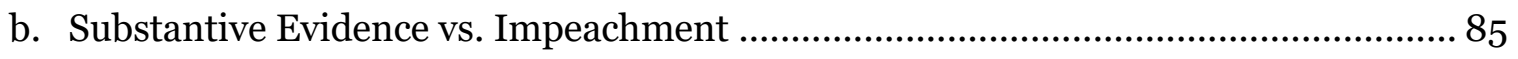

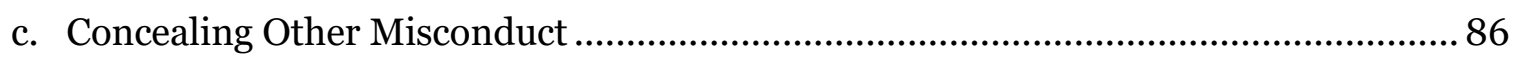

5. CATEGORIES OF CONCEALED INFORMATION......................................................89

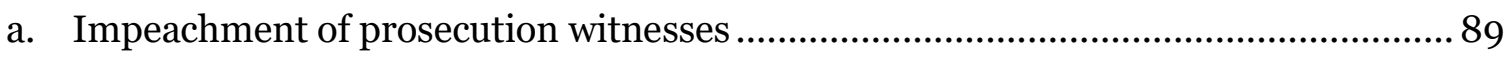

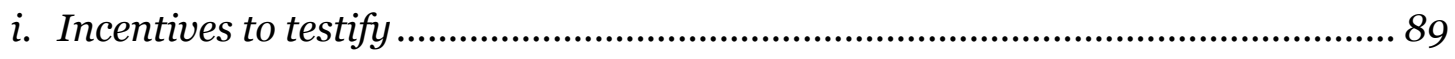

ii. Inconsistent statements ................................................................................. 90

iii. Criminal records and histories of dishonesty .................................................. 90

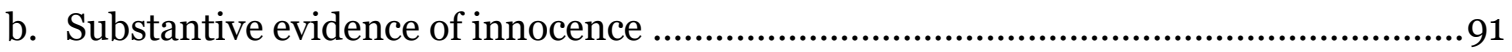

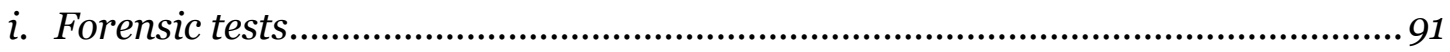


ii. Alternative suspects ....................................................................................... 92

iii. "I don't see him" and "Not the guy"..................................................................... 93

iv. Alibi evidence ............................................................................................... 94

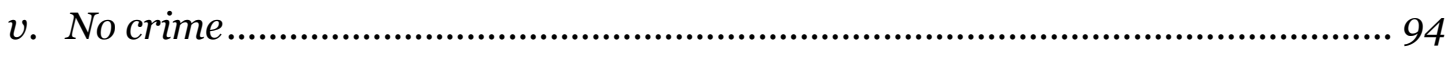

VIII. Misconduct at Trial................................................. 96

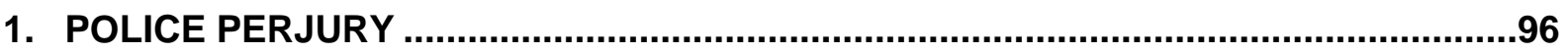

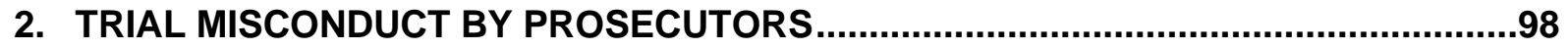

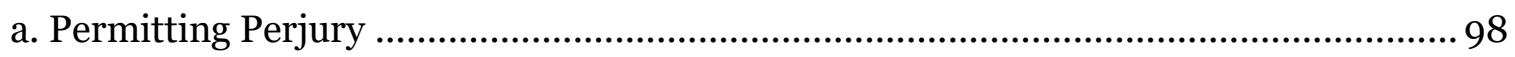

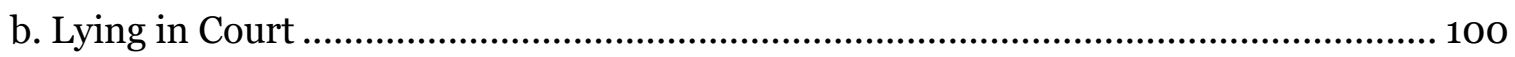

c. Improper Statements in Closing Argument or Cross-examination ................................103

IX. Federal Cases ...................................................... 108

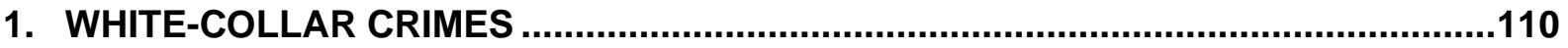

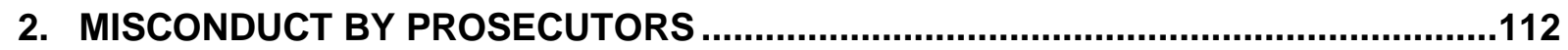

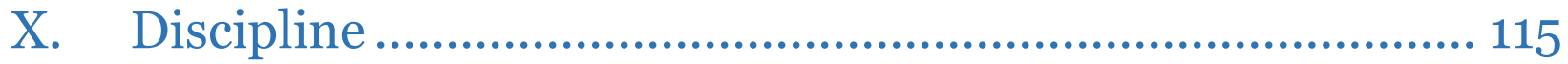

1. IN GENERAL

2. DISCIPLINE BY CATEGORY OF GOVERNMENT OFFICIAL ...................................119

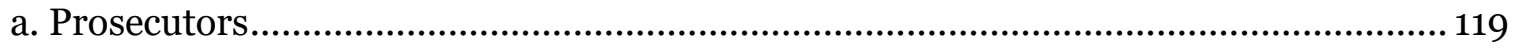

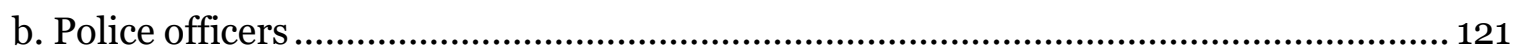

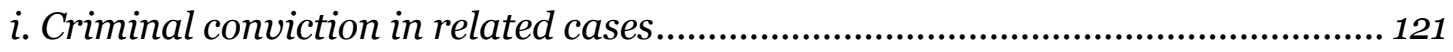

ii. Unreported employment and professional discipline ............................................123

c. Forensic Analysts ....................................................................................................124

3. SUMMARY

XI. Changes in Official Misconduct over Time ...................... 127

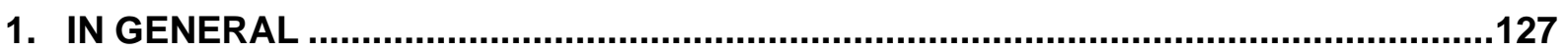

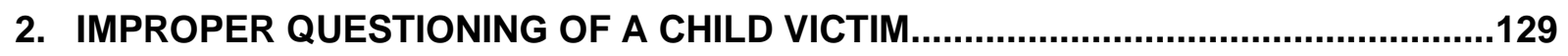

3. VIOLENCE AND OTHER MISCONDUCT IN INTERROGATIONS ...............................129 


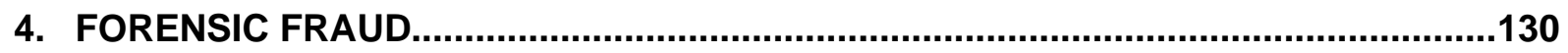

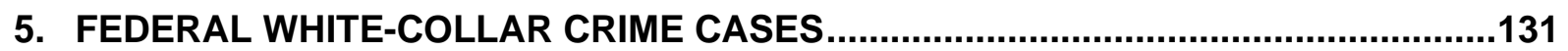

XII. Discussion and Conclusions ...................................... 133

1. WHY DO LAW ENFORCEMENT OFFICIALS COMMIT MISCONDUCT? ...................134

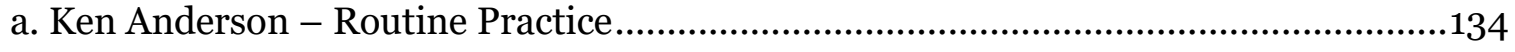

b. Richard M. Daley - Encouraging Brutality ...............................................................136

c. Joyce Gilchrist - Rewarding Fraud.......................................................................... 140

d. Officers Iannotto, Palmer, Pecorale, Martin, Visconti and Bishop, and Detective Massanova - Closing Cases ........................................................................................143

2. CAN WE REDUCE OFFICIAL MISCONDUCT IN CRIMINAL CASES? ........................144

a. Categories of Reforms .............................................................................................145

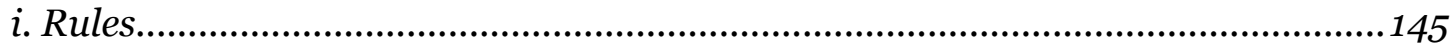

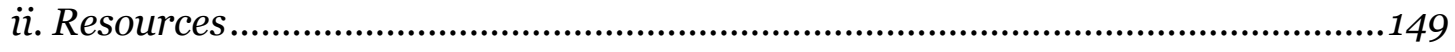

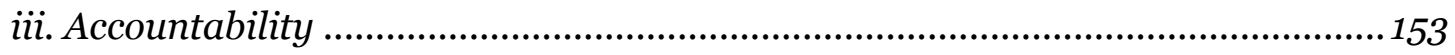

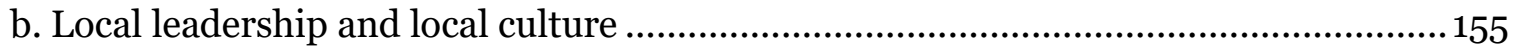

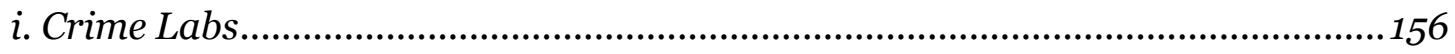

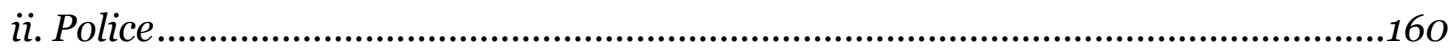

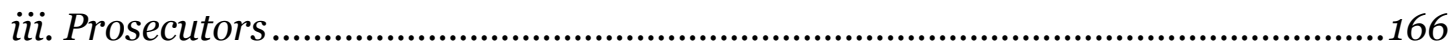

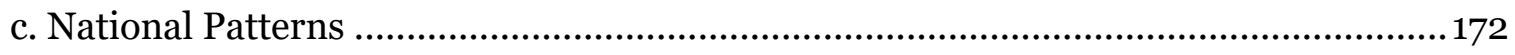

i. The United States Department of Justice ………………................................... 173

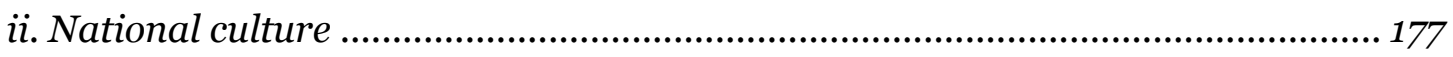

3. CODA

Methodological Appendix.........................................................182 


\section{Government Misconduct and Convicting the Innocent}

The Role of Prosecutors, Police and Other Law Enforcement

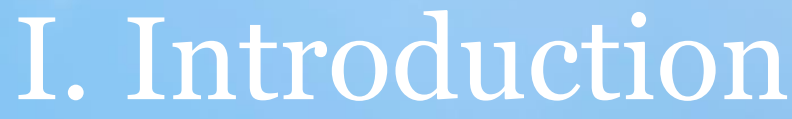

The National Registry of Exonerations lists all known defendants who were convicted of crimes in the United States and then exonerated by new evidence of innocence since 1989-a total of 2,400 cases as of February 27, 2019. In 1,296 of those cases, 54\%, misconduct by government officials contributed to the defendants' wrongful convictions. More than a third of all exonerations included misconduct by police officers, nearly as many involved misconduct by prosecutors, about one in seven included misconduct by other government officials, and quite a few had misconduct by more than one type of government official.

To state the obvious, this is not a measure of the frequency of official misconduct in all criminal cases. We cannot estimate the general rate of misconduct in criminal investigations or convictions from data on innocent defendants who were convicted and then exonerated. What we can say is that official misconduct is a major cause of convictions of innocent defendants.

The exonerations in which the misconduct occurred run the gamut of crime. At one end of the spectrum, 93 innocent defendants were sentenced to death at least in part because of official misconduct. For example:

On May 19, 1975, Frank Harold was gunned down and killed in a robbery in Cleveland, and a bystander was seriously wounded. Within days, 12-year-old Eddie Vernon told the police that he had witnessed the murder and identified 18year-old Ricky Jackson as the gunman and brothers Ronnie and Wiley Bridgeman as accomplices who fled the scene in a car with Jackson.

Jackson and the Bridgeman brothers were tried separately and convicted in August and September, 1975. All three were sentenced to death. No physical evidence connected them to the crimes, and none of the three had a criminal record. In each case, the conviction depended entirely on Eddie Vernon's testimony.

At a hearing in November 2014, Vernon testified that he had not seen the robbery or murder but had heard a rumor that Jackson and the Bridgemans were involved, and he came forward and lied because he wanted to help the police. He said that he had tried to recant before trial, but the police told him that because he was too young to go to jail they would arrest his parents for perjury if he 
backed out-so he went ahead and testified at the trials. The police never revealed that conversation to the court or the defendants.

By the time of the hearing, lawyers for the defendants had also learned that a suspect, whose car was seen at the scene-but who was ignored after Vernon came forward-pled guilty in 1976 to more than a dozen counts of aggravated robbery.

All three defendants were exonerated in 2014. Their death sentences had been commuted to life in prison. Ronnie Bridgeman had been paroled after 29 years in prison; Jackson and Wiley Bridgeman had each served more than 39 years for a crime they did not commit.

At the other end of the scale, some exonerations with official misconduct were for misdemeanors:

In July 2014, Wassillie Gregory was charged with "harassment" of a police officer, a misdemeanor, in Bethel, Alaska. The officer wrote in his report that Gregory was "clearly intoxicated" and that "I kindly tried to assist Gregory into my cruiser for protective custody when he pulled away and clawed at me with his hand."

Gregory pled guilty, without the benefit of a defense lawyer. Normally, that would be the end of the story. But this arrest was witnessed by an anthropologist from Arizona who was doing seasonal research in Alaska, and she filed a complaint with the police department. Gregory was exonerated a year later because a surveillance video showed the officer handcuffing him and then repeatedly slamming him onto the pavement.

The police in Ricky Jackson's case threatened the central witness in the case and forced him to testify falsely against the defendants. They also concealed critical exculpatory evidence, the fact that the only supposed eyewitness tried to recant his accusation and told them it was a lie.

In some ways, the misconduct by the police officer in Wassillie Gregory's case was worse than what Ricky Jackson and the Bridgeman brothers endured. He beat and seriously injured the defendant with no justification-and, of course, concealed the beating-and then he lied and framed the defendant for an assault that never occurred. This all happened, however, in a far less serious context, a misdemeanor prosecution for which the defendant received a suspended sentence and probation.

Many types of misconduct by prosecutors, police officers and others contributed to the convictions of these exonerated defendants. We will describe them in detail, but we begin with background information on the issue and the nature of our data, followed by a brief summary of the range of misconduct we have observed. 
misconduct-concealing exculpatory evidence-had "reached epidemic proportions in recent years," 3 and that courts were partly responsible because they failed to take action against the offending prosecutors.

In a law review article two years later, Kozinski expanded at length on that critique, and observed that "there are disturbing indications that a non-trivial number of prosecutors-and sometimes entire prosecutorial offices-engage in misconduct that seriously undermines the fairness of criminal trials." 4 One of the main indications Judge Kozinski pointed to was the high number of exonerations since DNA exonerations began in 1989.

Prior research on official misconduct roughly tracks public attention. There has been a great deal of interest and writing about misconduct by police officers in their interactions with civilians on the street: corruption, violence, racial and ethnic prejudice. 5 That behavior, however abhorrent, is not the sort of misconduct we address here since it does not produce false evidence of guilt or conceal true evidence of innocence; and little of the writing on police misconduct analyzes systematic data on police behavior. ${ }^{6}$

There is more systematic research on misconduct by prosecutors, mostly by journalists.

In 1999, Ken Armstrong and Maurice Possley reported in the Chicago Tribune that since 1963, at least 381 homicide convictions across the United States were reversed "because prosecutors concealed evidence suggesting innocence or presented evidence they knew to be false."7 Virtually no disciplinary actions were taken against the hundreds of prosecutors involved: one was fired but reinstated, another was suspended for 30 days. A later article in the same series identified 42 prosecutors in Chicago who obtained criminal convictions that were later reversed because of

3 United States v. Olsen, 737 F.3d 625, 631 (9th Cir. 2013).

${ }^{4}$ Alex Kozinski, Preface: Criminal Law 2.0, 44 Geo. L.J. Ann. Rev. Crim. Proc. iii, xxii (2015).

5 See, e.g., Rayman, Graham, The NYPD Tapes: Inside Bed-Stuy's 81st Precinct, The Village Voice, May 4, 2010, for the first in a series of articles on police misconduct in New York City; links to the entire series can be found at https://perma.cc/56U2-7J6V; Josefa Velasquez, Greg B. Smith \& Reuven Blau, The Complaint Files NYPD Unions Don't Want You to See, The City, July 31, 2020 (published in partnerships with ProPublica).

6 The major exceptions are studies of racial profiling-the discriminatory selection of African Americans and other minorities for police stops, searches, and occasionally arrests and prosecutions. See Jeffrey Fagan, Amanda Geller, Garth Davies, and Valerie West, "Street stops and Broken Windows revisited: The demography and logic of proactive policing in a safe and changing city," in Race, ethnicity, and policing: New and Essential Readings, edited by Stephen K. Rice and Michael D. White. New York, NY: NYU Press (2010); Amanda Geller \& Jeffrey Fagan, Pot as Pretext: Marijuana, Race, and the New Disorder in New York City Street Policing, J. OF EMPIRICAL LEGAL STUD. Vol. 7 (4), pp. 591-633 (2010); Samuel R. Gross \& Katherine Y. Barnes, Road Work: Racial Profiling and Drug Interdiction on the Highway, 101 Mich. L. Rev. 651 (2003).

Racial profiling does produce some criminal convictions, but in the contexts that have been studied systematically, the great majority of its victims are not arrested let alone convicted. These widespread practices of systematic racial discrimination produce few false convictions. Those who are charged are usually guilty-of minor crimes that are routinely ignored when committed by white people.

7 Ken Armstrong \& Maurice Possley, Trial \& Error: How Prosecutors Sacrifice Justice to Win. Part 1: The Verdict: Dishonor, CHI. TRIB. (Jan. 11, 1999). Sixty-seven of the defendants in those cases were sentenced to death; by 1999, 24 of those death-sentenced defendants had been exonerated. 
their misconduct, and who not only escaped any meaningful adverse consequences, but went on to become judges. ${ }^{8}$

In 2003, the Center for Public Integrity released a study of more than 11,000 state court criminal cases across the country since 1970 in which prosecutorial misconduct was alleged. Courts reduced sentences, dismissed charges, or vacated convictions in more than 2,000 of those cases, but only 44 prosecutors were the subject of state bar complaints, and of those, only two were disbarred and 12 were suspended. 9

A study in the Pittsburgh Post-Gazette in 1998 found much the same thing for prosecutorial misconduct in federal criminal cases. The Department of Justice investigated only 9 percent of some 4,000 complaints of misconduct by its prosecutors over 20 years, and of those, only 4 percent were found to have merit-approximately 15 cases all told. ${ }^{10}$ Twelve years later, USA Today reported that little had changed. From 1997 to 2010, judges found misconduct by federal prosecutors in 201 cases, but only six were disciplined by bar authorities. ${ }^{11}$

The most detailed study on the subject was released by Kathleen Ridolfi and Maurice Possley of the Northern California Innocence Project in 2010. ${ }^{12}$ They collected all decisions in which courts found that state prosecutors in California had committed misconduct in trials that led to convictions, 707 cases from 1999 through 2007. Only 159 of those convictions were reversed-in the remainder, the misconduct was deemed "harmless"-and, despite a legal obligation that California courts report all such findings to the California State Bar, only six California prosecutors were disciplined in any manner for misconduct in a criminal case in that nine-year period.

Taken together, the studies of prosecutorial misconduct reached two main conclusions: (i) a substantial number of prosecutors commit misconduct in criminal cases, and (ii) almost none are disciplined for it. This is an important contribution to our understanding of the problem. The journalists who conducted them did an impressive job of searching through thousands of cases to locate the small minority in which courts found that misconduct had occurred, and then determining whether the prosecutors involved were sanctioned.

\footnotetext{
8 Ken Armstrong \& Maurice Possley, Trial \& Error: How Prosecutors Sacrifice Justice to Win. Part 5: Break Rules Be Promoted, CHI. TRIB. (Jan. 14, 1999). A third article in the Chicago Tribune, by Armstrong and Steve Mills several months later, found that, "More than 10 percent of Illinois' death-penalty cases have been reversed ....because prosecutors took some unfair advantage that undermined a trial's integrity." Ken Armstrong \& Steve Mills, The Failure of the Death Penalty in Illinois: Part 1: Death Row Justice Derailed: Bias, Errors, and Incompetence in Capital Cases Have Turned Illinois' Harshest Punishment into Its Least Credible, Chi. Trib. (Nov. 14, 1999).

9 Ctr. for Pub. INTEgrity, Harmful ERror: InVestigating America's Local Prosecutors (2003). See Michael J. Sniffen, "Study finds thousands of cases of misconduct by prosecutors across U.S.," Journal Times (June 26, 2003).

10 William Moushey, Win at All Costs, Pitt. Post-Gazette, Nov. 22, 1998, at A.

11 Brad Heath \& Kevin McCoy, Prosecutors' Conduct Can Tip Justice Scales, USA Today (Sept. 23, 2010).

12 Kathleen M. Ridolfi \& Maurice Possley, Preventable Error: A Report On Prosecutorial Misconduct In California, 1997-2009, A Veritas Initiative Report (2010). See also Richard A. Rosen, Disciplinary Sanctions against Prosecutors for Brady Violations: A Paper Tiger, 65 N.C. L. REV. 693 (1987).
} 
These studies, of course, have limitations. The central one is that they are all based on official findings that misconduct occurred, usually in written opinions by judges (or in the Pittsburgh Post-Gazette study, internal Department of Justice memoranda). Most criminal cases, with or without misconduct, do not produce written court opinions; in fact, most convictions based on guilty pleas leave virtually no substantive records at all. In cases that do include court opinions, misconduct is often overlooked by lawyers and judges alike because nobody knew about it at the time. For other convictions, valid claims of prosecutorial misconduct are raised but rejected by courts because critical evidence to prove those claims has not yet come to light. We see that regularly in the records of cases that eventually do produce exonerations-and then, even when misconduct is an undisputed fact, the case may simply be dismissed with no formal finding.

In short, because prior studies rely on cases with findings of misconduct, and include no data on cases without misconduct, they can't speak to the rate of misconduct in all criminal cases, or in any subset of them, or to the features that distinguish cases with misconduct from those without, or to differences between the acts of misconduct that are identified by courts and those that they miss.

Our own study has a much richer database. We look at all convictions that end in exoneration, whether or not official misconduct occurred or was found by a court. Exonerations receive much more attention than run of the mill convictions, and we have done the best we can to assemble detailed information on all exonerations that we know about. That enables us to identify many instances of misconduct that cannot be found in court opinions. ${ }^{13}$

In other words, our data enable us to avoid some of the limitations imposed of prior researchbut not all.

\section{THIS STUDY}

\section{a. Our data}

Our data come from the files assembled by the National Registry of Exonerations on all known exonerations in the United States since the beginning of 1989. We define an exoneration as follows:

"A person has been exonerated if he or she was convicted of a crime and, following a post-conviction reexamination of the evidence in the case, was either: (1) declared to be factually innocent by a government official or agency with the authority to make that

\footnotetext{
${ }^{13}$ For example, Ridolfi \& Possley report that improper closing arguments were by far the most common type of misconduct by prosecutors found by California courts, about seven times more frequent than concealing exculpatory evidence. Ridolfi \& Possley, supra, at p. 25. As you'll see, our data on exonerations show that prosecutors conceal exculpatory evidence about ten times more often than they make improper arguments to the jury. Infra sections VII.3 and VIII.2.c. That reflects the different cases we consider.

Ridolfi \& Possley's cases are overwhelmingly initial direct appeals from criminal convictions, proceedings that are limited to reviewing the record of what happened in the trial court. Improper arguments are made in open court and are visible in trial transcripts. Concealed exculpatory evidence, by its very nature, is rarely known at that stage of the proceedings, but it's common among cases that end in exoneration, typically after long reinvestigations of the cases, and usually with no written finding on misconduct.
} 
declaration; or (2) relieved of all the consequences of the criminal conviction by a government official or body with the authority to take that action."14

We rely on the decisions of government officials to classify a case as an exoneration. Our task is limited to determining whether a convicted defendant was declared innocent or relieved of all consequences of the conviction, and-if the latter-whether that action "was the result, at least in part, of evidence of innocence that either (i) was not presented at the trial at which the person was convicted; or (ii) if the person pled guilty, was not known to the defendant and the defense attorney, and to the court, at the time the plea was entered." ${ }^{5}$

The Registry relies entirely on non-confidential data, primarily court records and exhibits, other official documents, news reports, and interviews with attorneys and others who worked on the cases in their professional capacity.

The Registry is an ever-changing public archive. We add cases steadily, about 200 a year, both exonerations that occurred in that year and ones from years or decades before. This report is based on a snapshot of the data in the archive (or rather, several snapshots). It includes the first 2,400 exonerations posted in the Registry, those posted as of February 27, 2019. The total has grown to 2,663 , as of this writing, and counting.

Those 2,400 cases, however, have not remained entirely static. We invite corrections and new information on cases we have listed, and we update and amend them regularly. We have removed several cases over the past eight years when new information has led us to conclude that they did not in fact meet our criteria, and we have changed many more. We have already learned, for example, that two exonerations among the first 2,400 in the Registry included official misconduct that we did not know about when we stopped coding the data for this Report. ${ }^{16}$ We are not aware of any situation in which these changes affect any general pattern we discuss.

We link to the Registry many times in this report. For example, in the Introduction we linked to our write-up of the exoneration of Ricky Jackson. The write-up that link takes you to is the current one; it includes information on a civil lawsuit by Jackson that was settled in May 2020, more than a year after we closed the book on additional exonerations for this Report. Similarly, this link will take you to the list of all exonerations in the Registry with official misconduct as of

${ }^{14}$ See National Registry of Exonerations, Glossary, which also includes a more detailed definition.

15 Id.

${ }^{16}$ Codefendants Jean Dorval, Duquene Pierre, and James Louis were convicted of murder in New Jersey in 1996. Pierre and Dorval were exonerated and added to the Registry in 2016 and 2018, respectively. We knew of no misconduct in their cases, and coded them accordingly. In June 2020, months after we completed all additions and corrections to the 2,400 exonerations that are the subject of this report, James Louis was also exonerated and we learned for the first time that the convictions of all three men were tainted by serious official misconduct, concealing exculpatory evidence and witness tampering. Louis's case is not included in this Report because he was exonerated after February 2019. Dorval and Pierre's cases are in the database for this Report, but they are coded as not including official misconduct because as of March 2020, we didn't know of any. 
when you click-1,443 on September 1, 2020-not the set of 1,296 exonerations with misconduct as of February 27, 2019, that this Report is based on.

"Official Misconduct" is a term of art. In general, it means that a prosecutor, police officer, or less frequently, forensic analyst or child welfare worker violated an official duty in the investigation or prosecution of a criminal case, and that violation contributed to the conviction of a defendant who was later exonerated. With a handful of exceptions, all acts of misconduct we considered fell into five broad categories: Witness Tampering, Misconduct in Interrogations, Fabricating Evidence, Concealing Exculpatory Evidence, and Misconduct at Trial.

A few types of official misconduct are public and visible for all to see-improper closing argument, for example. Most, however, are concealed-witness tampering, concealing exculpatory evidence, forensic fraud, and so forth. We determine whether misconduct occurred based on the information available to us, which inevitably means that we miss misconduct that was successfully hidden. ${ }^{17}$

Some forms of misconduct are deliberate by definition-perjury by a law enforcement official, or forensic fraud - and some are always deliberate in operation, such as violence in interrogations. Some are usually deliberate, but not inevitably-for example, misconduct in interrogations that does not include violence-and some, in particular concealing exculpatory evidence, may or may not be deliberate. One form of witness tampering-abusive questioning of a child victim-was probably never a deliberate act of misconduct because the officials involved believed it was appropriate and necessary.

The findings we report come from two overlapping datasets. We began this project in 2014 by coding detailed data on official misconduct for the first 1,361 cases in the Registry, those that had been posted by May 13, 2014. In April 2016, we added a series of new codes on official misconduct to all past cases we had posted, and to our ongoing protocol for gathering and recording data on cases that we add. Those data, which are available for all exonerations in the Registry, present and future, are the main source we rely on in this Report.

There are, however, a few issues on which we have more detailed data for the 1,361 cases that were posted by mid-May 2014. In particular, for some types of misconduct, that earlier study is the only source of data on the categories of the officials-prosecutors, police, etc. - who committed that misconduct. We discuss our use of these two datasets in more detail in the Methodological Appendix.

For now, we note that when we report a proportion that is based on the earlier, 1,361 case dataset, we italicize the fraction from which that proportion is derived, but when the proportion is based on all 2,400 exonerations, we do not. Thus, we would describe the proportion of all exonerations with any official misconduct in the 1,361 dataset as " $56 \%(768 / 1,361)$," while in the 2,400 dataset, the same proportion would be " $54 \%(1,296 / 2,400)$."

\footnotetext{
17 See infra Sections III.2 and III.3.
} 


\section{b. Advantages and limitations}

Our database is unique. We have detailed information on all known convictions of innocent defendants who were later exonerated. These are the criminal cases in which official misconduct produces its worst results: the conviction of innocent defendants. Because we have data on all exonerations, not just those with misconduct, we know that official misconduct played a role in more than half of the convictions of the exonerated defendants. Because we have detailed information about these convictions, we can begin to describe how this sort of misconduct operates-who does what, when, how, and in which cases.

There's a qualification. As we pointed out, we miss misconduct that was successfully hidden, so the rates we report are liable to be under-estimates.

We cannot, however, use these data to estimate the rate of misconduct in all criminal convictions. We're confident that official misconduct that might contribute to a false conviction is much more common in cases in which false convictions did in fact occur than in those in which they did not, but we have no measure of that second rate. That would require detailed data on a representative sample of all criminal convictions in the United States. No such data exist, and they would be nearly impossible to assemble. As we pointed out, the vast majority of convictions are based on guilty pleas, which usually produce little or no record of the process that led to the plea; and, unlike exonerations, almost none have the benefit of a reexamination of the evidence.

Nor can we generalize from these data on exonerations to all convictions of innocent people. As we discuss below, ${ }^{18}$ there are strong reasons to believe that the vast majority of people who are convicted of crimes they did not commit are never exonerated, especially those who are falsely convicted of property or drug crimes and sentenced to probation or short terms in jail. The frequency and the types of misconduct committed in those erroneous convictions may be different from what we see in cases of defendants who were exonerated, usually after spending years in prison for convictions for violent crimes.

Finally, a few words on two issues we do not address:

- We do not systematically discuss misconduct by criminal defense attorneys in representing their clients. Strictly speaking, misconduct by defense attorneys is not "official misconduct" because even public defenders, who are employed by the government, represent the defendants not the state. Nonetheless, we would have included defense attorneys in this study if we could, since they are all officers of the court, most are hired by the state, and-judging from anecdotal evidence-their misconduct and incompetence may do as much to produce false convictions as misconduct by prosecutors and police officers combined.

But we can't. The failures of defense counsel are overwhelmingly sins of omission, especially the failure to investigate their clients' cases. The absence of action is hard to

\footnotetext{
${ }^{18}$ Section III.2 and Section III.3.
} 
spot. A failure to even try to contact persuasive alibi witnesses will rarely be apparent at trial, and almost never when a guilty plea is taken. Unless such failures are actually litigated-which is uncommon-they are likely to remain unknown. ${ }^{19}$

- We do not discuss judicial misconduct for the same reason: absence of data. We know of a few exonerations after trial with severe misconduct by judges. At Lamonte McIntyre's murder trial in Kansas in 1994, for example, neither the judge nor the prosecutor revealed that they had been involved in a romantic relationship with each other. But such cases are rare. It may be that the underlying misconduct is also rare, but we wouldn't know. It is widely believed that judges are, to say the least, unreceptive to claims that they, or other judges, committed misconduct that prejudiced a litigant. As a result, except in the clearest cases, lawyers steer away from such claims and focus on less pejorative forms of judicial "error." If it's not litigated or investigated, we are not likely to know about it.

${ }^{19}$ See Samuel R. Gross \& Michael Shaffer, Exonerations in the United States, 1989 - 2012, at 41-43, National Registry of Exonerations (2012), for a more complete description of this problem. We do list some exonerations in which we know that the legal defense was severely ineffective, but only as examples. 


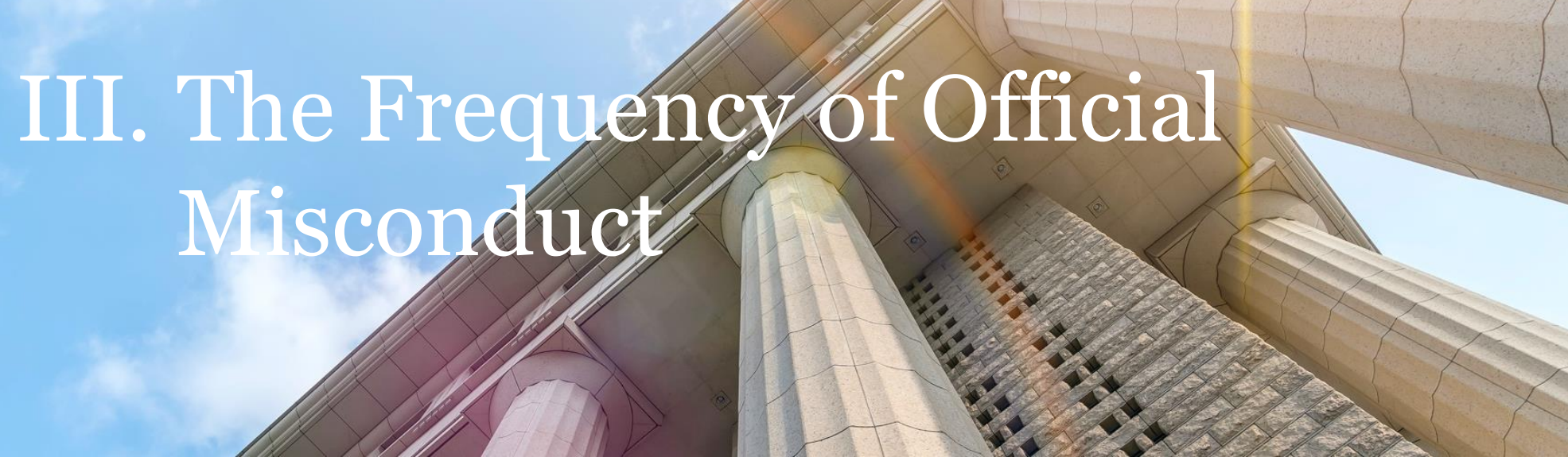

\section{IN GENERAL}

Official misconduct contributed to the conviction of innocent defendants in $54 \%$ of known exonerations-in most cases, more than one type of misconduct. There are modest differences in the rates of official misconduct by the sex and race of the exonerees. The overall rate is $55 \%$ for male exonerees and $46 \%$ for females, and, among major racial and ethnic groups, ranges from $57 \%$ for Black exonerees to $51 \%$ for whites. See Table 1 . There are, however, considerably larger differences by race among exonerations for some crimes, and for specific types of misconduct, as we'll see in Section III.4.

Table 1: Proportions of Exonerations with Official Misconduct by Characteristics of Exonerees

\begin{tabular}{|c|c|}
\hline Male & $55 \%$ \\
\hline \multicolumn{2}{|l|}{ Female } \\
\hline White & $52 \%$ \\
\hline Black & $57 \%$ \\
\hline Hispanic & $53 \%$ \\
\hline Other Race or Ethnicity & $40 \%$ \\
\hline All Exonerees & $54 \%$ \\
\hline
\end{tabular}

About a third included misconduct by prosecutors and slightly more involved misconduct by police-the two types of officials who play central roles in all criminal convictions. Forensic analysts and child welfare workers participate in many fewer criminal cases, and committed misconduct in only $3 \%$ and $2 \%$ of exonerations, respectively. See Table 2 . 
Table 2: The Frequency of Misconduct in Exonerations by Category of Official Actor*

\begin{tabular}{|c|c|c|}
\hline \multirow{5}{*}{$\begin{array}{l}\frac{0}{\frac{0}{0}} \\
\frac{0}{0} \\
\frac{7}{0}\end{array}$} & Prosecutors & $30 \%$ \\
\hline & Police & $35 \%$ \\
\hline & Forensic Analysts & $3 \%$ \\
\hline & Child Welfare Workers & $2 \%$ \\
\hline & All Official Actors & $54 \%$ \\
\hline
\end{tabular}

* Some exonerations include misconduct by officials in more than one category.

Exonerations with misconduct by child welfare workers (50) were all child sex abuse cases (including two murder prosecutions that also involved child sex abuse). Those with misconduct by forensic analysts were overwhelmingly murders (33/75) and sexual assaults (29/75), with a scattering of other crimes. Misconduct by prosecutors and by police are tabulated separately in Table 3. They occur regularly in exonerations from convictions in every category of crime.

Table 3: Proportion of Exonerations with Misconduct by Prosecutors and Police, by Crime

\begin{tabular}{lcc|c} 
& $\begin{array}{c}\text { Misconduct by } \\
\text { Prosecutors }\end{array}$ & $\begin{array}{c}\text { Misconduct } \\
\text { by Police }\end{array}$ & $\begin{array}{c}\text { ALL OFFICIAL } \\
\text { MISCONDUCT* }^{*}\end{array}$ \\
\hline Murder (908) & $44 \%$ & $48 \%$ & $72 \%$ \\
\hline Child Sex Abuse (270) & $25 \%$ & $28 \%$ & $44 \%$ \\
\hline Sexual Assault (320) & $20 \%$ & $22 \%$ & $39 \%$ \\
\hline Robbery (122) & $27 \%$ & $17 \%$ & $38 \%$ \\
\hline Other Violent Crimes (270) & $30 \%$ & $36 \%$ & $55 \%$ \\
\hline Drug Crimes (317) & $9 \%$ & $34 \%$ & $39 \%$ \\
\hline White-collar Crimes (63) & $57 \%$ & $11 \%$ & $62 \%$ \\
\hline Other Non-Violent Crimes (130) & $12 \%$ & $25 \%$ & $32 \%$ \\
\hline ALL CRIMES (2,400) & $30 \%$ & $35 \%$ & $54 \%$ \\
\hline
\end{tabular}

* The numbers in this column include cases with misconduct by forensic analysts and child welfare workers; some exonerations include misconduct by officials in more than one category.

In general, the rates of misconduct by prosecutors and police occurred at comparable rates among exonerations for particular crimes, with two exceptions: 
Among drug crime exonerations, the rate of misconduct by police (34\%) is almost four times the rate of misconduct by prosecutors (9\%). This is partly due to clusters of cases in which police planted drugs on innocent suspects. ${ }^{20}$

Among white-collar exonerations, the rate of misconduct by prosecutors (57\%) is more than five times the rate of misconduct by police (11\%). White-collar exonerations have both the highest rate of misconduct by prosecutors and the lowest rate of misconduct by police of any crime category. That pattern is driven entirely by federal white-collar exonerations: they constitute almost three-quarters of all white-collar cases (46/63), and $65 \%$ of them involved misconduct by prosecutors (30/46). ${ }^{21}$ As a result, the rate of prosecutorial misconduct is higher for white-collar crimes than for any other exonerations, and the overall rate of misconduct is second only to murder.

These tabulations only include known acts of misconduct that contributed to the convictions of the exonerated defendants. Many serious acts of misconduct don't qualify. In some cases, there was misconduct that was unrelated to the determination of the defendant's guilt or innocence. William Carter, for example, was beaten by police officers who planted drugs on him and arrested him twice in Chicago in 2006-but beating up a suspect who is not questioned produces no false evidence of guilt and conceals no true evidence of innocence. Neither does lying about the source of information in an application for a search warrant, as an officer did in Joseph Green's case, since such lies play no part in the trial at which a defendant's guilt is determined.

In other cases, state officials tried to obtain false evidence of guilt, or to hide true evidence of innocence, but failed. Nathan Dwight, for example, was told by a detective in Rockwell, Georgia, that he'd better come clean and confess because the all-white jury he would face would see him as a "straight-up nigger"-but Dwight did not confess. And in Glen Nickerson's case, police officers threatened to charge alibi witnesses as accomplices and to have their children taken away by the state if they testified on his behalf, but the witnesses testified anyway.

\section{THE COMMISSION AND THE DISCOVERY OF MISCONDUCT}

Since most people who commit misconduct hide it, if they can, we can only study those acts that come to light. The frequency of the known official misconduct that we discuss here is a function both of the underlying rate at which misconduct is committed and the proportion of cases in which it is uncovered. Both factors vary from one category of exoneration to another.

Commission. Consider the case of Homer Taylor III:

In 1988 Taylor pled guilty to third-degree statutory rape in Gray Harbor, Washington, for having consensual sex with an underage female in 1982 when he was 24. Twenty-two years later, in 2010, Taylor was convicted for failing to register as a sex offender and sentenced to 43 months in prison. The following

\footnotetext{
${ }^{20}$ See Section III.3.c.i

${ }^{21}$ See infra Section III.3.d and Section IX. By comparison, only 35\% of the small number of state law white-collar exonerations include misconduct by prosecutors (6/17).
}

Government Misconduct and Convicting the Innocent The Role of Prosecutors, Police and Other Law Enforcement 
year he was exonerated because within a year of his guilty plea, Washington State repealed the statutory rape law under which he was convicted, and the Washington sex offender registration statute did not apply to convictions under that repealed law. Apparently, nobody had noticed this issue before Taylor's appeal. ${ }^{22}$

The Registry includes 24 exonerations of defendants like Taylor who were wrongfully convicted of failing to register as a sex offender. None of them include any known official misconduct, probably because none occurred. In all of these cases, the underlying problem is clearly that the defendants, police officers, lawyers and judges involved-all of them-mistakenly believed that the defendant was required to register when in fact he was not. It's theoretically possible that some government official deliberately arrested, charged or prosecuted a defendant for failing to register while knowing that he was not obliged to do so, but we see no indication that ever occurred.

On the other hand, Duarnis Perez, who was exonerated in 2006 after serving four years in prison for illegally entering the United States, was a victim of official misconduct. A federal judge found that the government had violated Perez's constitutional rights by failing to inform him at trial that he could not be guilty of that crime because, unbeknownst to him and his family, he had become an American citizen 12 years earlier, at age 15, when his mother was naturalized as a citizen.

Perez is one of four exonerees in the Registry who were convicted of immigration law offenses. All four cases include official misconduct. Four exonerations are too few to reach any general conclusions, but it looks like law enforcement officials are more likely to commit misconduct to convict defendants accused of immigration offenses than to convict those charged with failing to register as sex offenders.

Discovery. As we'll see, the Registry includes 149 cases from Harris County, Texas (Houston), in which defendants who pled guilty to drug possession were exonerated by lab tests that unexpectedly showed that the materials seized from them contained no illegal drugs. ${ }^{23}$ None of those cases included any police misconduct, but that doesn't mean none occurred. Officers may have lied about where they found the suspected drugs, or about what the suspects said-both items of evidence that might show that the arrested defendants knowingly possessed the materials-but once the serendipitous lab results appeared, no one bothered to look any further because exoneration was inevitable. In many murder exonerations, by contrast, finding official misconduct is essential just to get a hearing on a claim of innocence.

\footnotetext{
22 State v. Taylor, 259 P.3d 289, 162 Wash. App. 791 (2011). The decision in Taylor led to three other Washington State sex offender registration exonerations: the exoneration of Ollie Church, and two separate exonerations of Michael Wheeler.

${ }^{23}$ See infra Section III.3.c.ii.
} 


\section{MISCONDUCT BY CRIME}

a. Violent Felonies

Almost $78 \%$ of known exonerations in the United States are for violent felonies $(1,872 / 2,400)$. Table 4 displays the rate of known misconduct in exonerations for violent crime convictions, with murder cases subdivided by penalty. In general, the more severe the crime, the higher the rate of misconduct, ranging from $79 \%$ in murder cases with death sentences to $38 \%$ in robbery cases.

Table 4: Rate of Official Misconduct in Exonerations for Violent Felonies, by Crime*

\begin{tabular}{|c|c|c|}
\hline \multirow{5}{*}{$\begin{array}{l}\text { 山् } \\
\text { 음 } \\
\text { 을 }\end{array}$} & Murder (908): & \multirow{2}{*}{$\begin{array}{l}72 \% \\
79 \%\end{array}$} \\
\hline & Death Penalty (121) & \\
\hline & Life Imprisonment (377) & $73 \%$ \\
\hline & Term Less Than Life (410) & $69 \%$ \\
\hline & Manslaughter (45) & $60 \%$ \\
\hline & Felonious Assault (82) & $57 \%$ \\
\hline & Attempted Murder (50) & $48 \%$ \\
\hline & Arson (23) & $48 \%$ \\
\hline & Child Sex Abuse (269) & $44 \%$ \\
\hline & Kidnapping (15) & $40 \%$ \\
\hline & Sexual Assault (320) & $39 \%$ \\
\hline & Robbery (122) & $38 \%$ \\
\hline \multicolumn{2}{|c|}{ ALL CASES $(2,400)$} & $54 \%$ \\
\hline
\end{tabular}

\footnotetext{
* Table 4 does not tabulate separately 53 exonerations for violent crimes that account for fewer than 10 cases each in our data, such as Child Abuse ( 9 cases) and Accessory to Murder (8 cases).
}

Why do exonerations for severe crimes include more known misconduct than those for less severe offenses? The answer seems to involve both of the components of known misconduct: official misconduct is more likely to occur in exonerations for more aggravated crimes, especially murder, and misconduct that occurs in such cases is more likely to be detected. 
The starting point is a well-established fact about exonerations: the more serious the crime, the higher the rate of exoneration. ${ }^{24}$ A recent article estimates the relative rates of exoneration in the Unites States from 1989 through 2016 for robbery, rape, non-capital murder and death sentences, by setting the lowest rate-that for robbery-at 1 , and calculating the ratios for other crimes. The results are startling. The estimated rate of exoneration for non-capital murders is more than four times the rate for rape and 37 times the rate for robbery, and the rate for death sentences is about six times that for other murder convictions. See Table $5 \cdot{ }^{25}$

\section{Table 5: Estimated Relative Exoneration Rates}

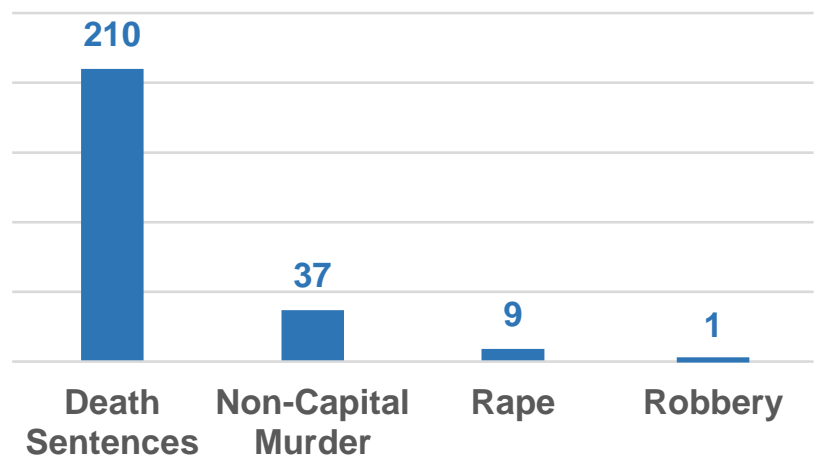

The difference between the rates of exoneration for rape and robbery can be explained in large part by the use of DNA testing to prove the innocence of convicted defendants: biological trace evidence that can be tested for DNA is common in rape cases, but rare among robberies. ${ }^{26}$

There is, however, no technological advantage in proof of innocence that explains the much higher rate of exoneration for murders-especially for capital murders-than for lesser crimes. On the contrary, most murder investigations are handicapped by the absence of live victims to

\footnotetext{
24 This pattern holds for felony convictions in the United States. Our data are limited to the United States, and include too few misdemeanor exonerations to draw any general conclusions.

25 Samuel R. Gross, What We Think, What We Know and What We Think We Know About False Convictions, 14 OHIO J. CRIM. L. 753, 766 (2017).

26 The need for post-conviction DNA testing in rape cases has been diminishing, as DNA testing is increasingly used before trial to prevent false convictions in the first place. As a result, the number of sexual assault exonerations with DNA evidence has drifted downward in the last 18 years. See Table A:
}

Table A: Sexual Assault Exonerations with DNA Evidence by Year

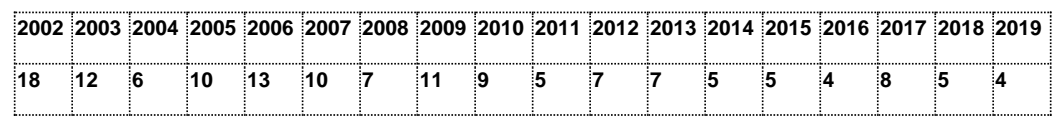


describe the crimes and identify the criminals. Instead, the plausible explanation is that we devote more time and resources to murder cases, at every stage:

(i) Wrongful convictions are more likely to occur in murder cases because police and prosecutors work harder to secure murder convictions in cases with weak evidence than they do for lesser crimes.

(ii) False murder convictions are more likely to be identified, and the innocent defendants exonerated, because defense attorneys, journalists, courts and law enforcement officers devote much more time and many more resources to doing so, especially if the defendant might be put to death.

Both of those processes also increase the rate of known misconduct among murder exonerations, along with overall rates of known exonerations.

Commission of misconduct. Murders are much more likely to produce criminal convictions than other violent crimes. Most other felonies are never reported to the police. In 2018, for example, only $43 \%$ of violent crimes other than murder were reported to the police, ${ }^{27}$ but almost all homicides are known to authorities because the bodies of the deceased must be interred or cremated, and the cause of death will be determined to be homicide. Among crimes that are known to the police, the clearance rate-the proportion of reported crimes for which the criminal is identified and if possible arrested-was about double for murder, at $62 \%$, than other violent crimes such as rape, $33 \%$, or robbery, $30 \% .^{28}$

This is as it should be. Police and prosecutors work harder on murder cases because murder is far worse than other crimes. They're more motivated to solve murders, and they're under more pressure to do so. The main effect is what we want: more murderers are caught and convicted than criminals who commit other crimes. An investigation that would be closed without arrest if it were a mere robbery may end in a conviction if the robber killed one of his victims. But the time and attention that are devoted to murders can also produce mistakes. Because the authorities pursue difficult murder cases with weak evidence-cases that would be abandoned if nobody had been killed-there is higher risk that innocent defendants will be convicted.

That strong impulse to secure convictions can also lead to misconduct. If a murder cannot readily be solved, the authorities may be tempted to cut corners, jump to conclusions, and-if they believe they have the killer-manufacture evidence to clinch the case, or hide evidence that suggests innocence. The danger that they will go too far is magnified to the extent that the killing is brutal and horrifying and attracts public attention-factors that also increase the likelihood that the murder will be treated as a capital case. The rape-murder of a young girl is a telling example:

In February 1983, ten-year-old Jeanine Nicarico was abducted from her home in Naperville, Illinois, raped, and killed-a crime of stunning brutality. The murder

27 Rachel E. Morgan \& Barbara A. Oudekerk, Criminal Victimization, 2018, U.S. Dep't of Justice (Sept. 2019).

${ }^{28}$ Fed. Bureau of Investigation, 2018 Crime in the United States, (last visited Mar. 4, 2020). 
was the subject of a long, frustrating, unsuccessful investigation-a humiliating public failure. Thirteen months after the murder-and less than two weeks before the local prosecutor stood for reelection-three men were indicted: Rolando Cruz, Alejandro Hernandez, and Stephen Buckley. Cruz and Hernandez were convicted and sentenced to death in 1985 .

Ten years and two appeals later, at Cruz's third trial, the case fell apart when a police officer admitted he had given false testimony, perhaps inadvertently, when he provided critical corroboration to the claim of other officers that Cruz had made an unrecorded statement that included details of the killing that only the criminal would know. The judge entered a judgment of acquittal. Apparently, working under intense pressure, the police convinced themselves that they knew who killed Jeanine Nicarico, and then manufactured evidence to convince prosecutors and for use in court.

What if this had not been a murder case? What if the criminal had taken expensive jewelry from the Nicarico home rather than a child-or even if he had knocked out a family member, or set the home on fire? As long as no one was killed, chances are the case would have been closed after a comparatively short investigation with no arrests, no trials, no police perjury, and no false convictions.

We have no data on charges that were not pursued in less horrific crimes, but we see echoes of this stark difference in the investigations of cases that were prosecuted and ultimately ended in exoneration. For example, just over a quarter of all exonerations include one or more recantations by prosecution witnesses $(620 / 2,400)$, primarily murder and child sex abuse cases. In $71 \%$ of murder cases with recantations, recanting witnesses reported that police or prosecutors pressured them to lie (260/365); in child sex abuse cases, only $39 \%$ of recanting witnesses said they were pressured to lie by law enforcement officials (50/129). ${ }^{29}$ This suggests that when the evidence in a child sex abuse investigation is weak, the authorities are more likely to close the case with no charges, but when it's a murder case, they're more likely to pressure witnesses to testify against the defendants in court-which sometimes leads those witnesses to lie, and produces false convictions.

Discovery of misconduct. In many cases, misconduct that contributed to a false conviction only came to light as a result of comprehensive, painstaking, long-running investigations. Murder cases, especially those that result in death sentences, are the main candidates for detailed postconviction investigations. John Thompson's case is a clear example:

In 1984, John Thompson was arrested for a highly-publicized robbery murder in New Orleans. After his picture was published in local newspapers, he was misidentified as the robber in an earlier carjacking. The prosecutor went to trial in the carjacking case first, and got a robbery conviction in April 1985, so he could

${ }^{29}$ On the other hand, $47 \%$ of child sex abuse recanters said that they had been pressured to lie by civilians, mostly family members $(60 / 129)$, compared to $7 \%$ of recanters in murder exonerations $(25 / 365)$. 
use that conviction against Thompson at his murder trial-which he did, and he got a death sentence a month later.

Fourteen years later, 30 days before Thompson was set to be put death, an investigator conducted a last-ditch effort to prevent Thompson's execution. He discovered that there was a blood stain from the robber on the clothing of one of the carjacking victims, that the stain was tested by the prosecution before trial, and that the test showed that the blood did not come from Thompson. All of this had been concealed from the defense by prosecutors, who went so far as to improperly remove the piece of cloth with the blood stain from the police property room and eventually lose or destroy it. ${ }^{30}$

Thompson's carjacking conviction was dismissed. Three years later he was granted a new trial in the murder case, and in 2003 he was acquitted by a jury that deliberated for 35 minutes. By then Thompson's attorneys had also discovered that the prosecution had concealed the fact that a witness who testified that Thompson admitted to the murder had received a reward for his testimony, and that prosecutors had allowed that witness to lie about that at trial.

What stands out about Thompson's case is not that it took so long to find the misconduct, but that it was ever found at all. As former Chief Judge Alex Kozinski of the United States Court of Appeals for the Ninth Circuit observed, "If a prosecutor fails to disclose exculpatory evidence to the defense, who is to know?" ${ }^{1}$

Thompson was only exonerated from his robbery conviction because he was also convicted of murder and sentenced to death. He was saved by a scorched-earth reinvestigation that uncovered deeply-hidden facts. Investigations like that are expensive, time consuming and extremely rare in criminal cases with poor defendants-except for some defendants who are sentenced to death.

If Thompson had merely been convicted of robbery (and sentenced to 49 years in prison, as he was) the misconduct in the carjacking case would never have been discovered. Of course, the outrageous misconduct in Thompson's carjacking case would probably never have occurred if prosecutors had not treated his robbery trial as the first act of a capital murder trial.

Some murder exonerations do not require long, searching investigations. In November 2011, in Brown County, Texas, Randall Philen was convicted of murdering his brother two years earlier. Seven weeks later, a confidential informant gave the police the names of the real killers: four men who broke into the victim's home to rob him of drugs and money and killed him in the process. Within a day, one of the four confessed and his fingerprints matched a print found at the crime scene. Philen was released immediately and exonerated two months later.

30 Connick v. Thompson, 563 US 51, 83-83 n.4-6 (2011) (Ginzburg, J dissenting).

${ }^{31}$ Alex Kozinski, Preface: Criminal Law 2.0, 44 Geo. L.J. AnN. Rev. Crim. Proc. iii, xxiii (2015). 
Philen's fast-path exoneration did not uncover any misconduct-or, as far as we know, anything else about the investigation and prosecution that led to his conviction. There was no need. The first batch of new evidence included the identities of the real killers. One reason we know of more misconduct in exonerations for murder than for rape is that murder exonerations include many hard cases, like Thompson's, and few easy ones, like Philen's.

There was no time to re-investigate Philen's case for misconduct before his exoneration, but if anybody had been interested, there were avenues to explore after exoneration. At his week-long trial two months earlier, the prosecutors presented extensive (and misleading) forensic evidence, and testimony from family members and others about the relationship between Philen and his dead brother, and about their drug dealings. Either category of evidence, or both, might have been obtained by misconduct. But there was little incentive to pursue a claim for compensation for the 49 days he spent in custody after conviction, and no claim of any sort was filed. Philen's case is an outlier among murder exonerations. The average time a murder exoneree spent in custody from conviction to release was 13.9 years, more than 100 times what Philen served.

\section{b. Non-violent crimes in general}

Non-violent crimes account for more than $80 \%$ of felony convictions in state courts in the United States ${ }^{32}$ (and, as best we can tell, at least a similar proportion of misdemeanor convictions 33 ), but only $19 \%$ of felony exonerations involve non-violent crimes $(429 / 2,311)$. That means that the overall exoneration rate for violent felonies is about 17 times higher than the rate for nonviolent felonies, and the exoneration rate for murders is about 100 times greater-a huge gap. Unless the accuracy of determining guilt or innocence for non-violent crimes puts murder and sexual assault trials to shame, only a miniscule minority of wrongful convictions for crimes without violence are ever reconsidered or reversed.

Overall, official misconduct contributed to the false convictions in $40 \%$ of exonerations for nonviolent crimes (205/510). That rate, however, varies greatly depending on the specific category of the crime, and the nature of the investigations that proved the innocence of the defendants.

About 8\% of exonerations for non-violent crimes involve several types of property crimes (40/510),34 and another $14 \%$ are for a variety of what we call, collectively, "regulatory" crimes, such as failure to pay child support or register as a sex offender, immigration offenses, illegal

\footnotetext{
32 See e.g., Bureau of Justice Statistics, Felony Sentences in State Courts, 2006- Statistical Tables, NCJ 226846 (revised Nov. 22, 2010).

33 There are no systematic data on the nature of misdemeanor convictions in the United States. See generally Alexandra Natapoff, Punishment Without Crime, Basic Book: New York (2018); but see, Sandra Mayson \& Megan Stevenson, Misdemeanors by the Numbers, 61 B.C. L. REV. 971 (2020), (containing a tabulation of misdemeanor filings in 8 jurisdictions across the country; in one (Chicago), violent misdemeanors appear to account for perhaps $30 \%$ of total; in all others, less than $20 \%$. Id. at p. 1000 , figure 3 ).

34 These cases include burglary and other unlawful entries, destruction of property, possession of stolen property, and theft.
} 
possession of a gun, and so forth (74/510).35 The rates of official misconduct among these exonerations are comparatively modest, $25 \%$ for property offenses (10/40) and $31 \%$ for "regulatory" crimes (23/74).

Three-quarters of exonerations for non-violent crimes involve two well-defined but very different categories of crime: drug crimes, which make up $62 \%$ of non-violent crime exonerations (317/510), and white-collar crimes, which make up 12\% (63/510). We say a bit more about these categories in the sections that follow.

\section{c. Drug crimes}

An exoneration for a violent felony usually begins with a substantial claim that a specific convicted defendant is innocent. That may lead to a reinvestigation of the crime, which may in turn lead to exoneration-and sometimes uncover misconduct along the way.

Two-thirds of drug-crime exonerations, however, were not the result of distinct investigations of individual cases. Instead, they occurred in two very different clusters of cases, 65 exonerations in Cook County, Illinois (Chicago), and 149 in Harris County, Texas (Houston). The exonerations in each cluster attracted attention because of common features that made it comparatively easy to obtain exonerations. The common features, however, were very different from one county to the other.

The overall rate of misconduct in drug-crime exonerations is $39 \%(123 / 317)$, but that average masks a stark disparity between these clusters. In Cook County, Illinois, $100 \%$ of drug-crime exonerations included official misconduct (73/73), while in Harris County, Texas, only $3 \%$ of drug crime exonerations included misconduct (4/149). Among drug crime exonerations from the rest of the country, the rate of official misconduct was $49 \%(46 / 94 .)^{36}$

i. Group exonerations: Cook County, Illinois

On August 4, 2006, 28-year-old George Almond was visiting a friend at a public housing development in Chicago, Illinois, when Police Sergeant Ronald Watts and officers under his command raided the building looking for drugs. Watts had a reputation for planting drugs on people, so Almond remained in the apartment until he thought the police had left. When he walked into the hallway, however, Watts was there.

Watts ordered Almond to stop and asked him for money. When Almond said he only had a few dollars, Watts arrested him for possession of narcotics. At the police station, when Almond asked what he was being charged with, an officer placed 20 baggies of heroin on the table and Watts said the drugs were Almond's.

\footnotetext{
35 These cases also include filing a false report, solicitation, and traffic offenses.

${ }^{36}$ We also know of seven drug crime exonerations in Harris and Cook counties that are not part of the clusters we describe below.
} 
On October 5, 2006, Almond pled guilty in Cook County Circuit Court to possession of a controlled substance. He was sentenced to two years in prison and released 16 months later, in February 2008.

Normally, that would be it. It's basically impossible to win a case that pits the word of an accused drug dealer against that of two or three police officers-even if somebody cared enough to fight that battle on behalf of a drug defendant who pled guilty and was released after 16 months in prison.

Four years later, however, Watts and one of his officers were arrested after they were caught on camera stealing money from a confidential FBI informant posing as a drug courier. Federal prosecutors said that Watts "used his badge and his position as a sergeant with the Chicago Police Department [CPD] to shield his own criminal activity from law enforcement scrutiny. He recruited another CPD officer into his crimes, stealing drug money and extorting protection payments from the drug dealers who terrorized the community that he... had sworn to protect." 37 In 2013, Watts pled guilty to taking money from the fake drug courier; he was sentenced to 22 months in federal prison.

Watts's conviction ended his police career and prevented him from framing new defendants, but it did not, on its own, affect George Almond's conviction. That process depended on another of Sergeant Watts's victims, Ben Baker. Baker was arrested twice by Watts and his team (the first time charges were dismissed)-and then a third time, with his wife, after he filed a complaint against the police for planting drugs on him. Baker went to trial and was sentenced to 18 years, after which he pled guilty to another four years in a deal that kept his wife out of prison.

In early 2016, after years of litigation on his behalf by the Exoneration Project at the University of Chicago Law School, Baker was exonerated from both convictions-which led to claims by many other defendants that Watts and officers working under him planted drugs on them too when they refused or were unable to pay the extortion money the officers demanded.

Reinvestigations by the Exoneration Project and other civil rights and criminal defense attorneys, and by the Conviction Integrity Unit of the Cook County State's Attorney's Office, led to two additional Sergeant Watts exonerations in 2016, 17 exonerations in 2017, 31 in 2018 (including one defendant who was framed for possession of an illegal gun rather than drugs), and 14 in early 2019-a total of 66 through February 2019. $3^{8}$ George Almond himself was exonerated in November 2018, more than ten years after he was released from prison.

37 United States vs. Ronald Watts, United States District Court Northern District of Illinois Eastern Division, Government's Response to Defendant Ronald Watts' Sentencing Memorandum, October 2, 2013; PACER document Case: 1:12-cr-00087 Document \#: 84 Filed: 10/02/13 Page 1 of 12 Page ID \#:431.

${ }^{38}$ As of this writing, 11 additional Watts exonerations have been added to the Registry among the 261 exonerations since the initial 2,400 , for a total of 77 .

We also know of six Cook County drug exonerations that occurred before 2016. All included official misconduct, but none involved Sergeant Watts. 
What Watts and his crew did in Chicago is hardly unique. It's one of 17 collections of cases across the country, from 1990 through 2018, that we have described as "group exonerations." 39 Exonerations, of course, can be grouped in any number of ways, but what we mean by a "group exoneration" in this context is very specific: The exoneration of a group of defendants who were deliberately framed for crimes that did not occur as part of a large-scale pattern of police perjury and corruption.

In almost all the group exonerations of that sort, police officers framed innocent defendants by the same method used by Sergeant Watts and his men in Chicago: they planted drugs on them, or simply booked the drugs in evidence and said they were found in searches of the defendants, their cars or their belongings.

Those frame-ups produced false convictions for comparatively minor crimes. Most defendants were sentenced to probation, or to several months, or one or two years in custody. It's prohibitively expensive to try to establish innocence in such cases; it basically never happensunless some feature of the case makes the process quick and easy. For group exonerations, the common practice of misconduct by an identified group of police officers fills that function: once that's been established, proving innocence in a particular case is relatively easy.

Most of the exonerees in these group exonerations are not listed in the Registry because we know too little about their cases to describe them individually, or to be confident that the exonerations reflect a high probability of innocence. $4^{\circ}$

In some of those group exonerations, after the underlying pattern of corruption and perjury came to light, specific exonerations were handled summarily and received little or no separate attention. As a result, we often don't know basic facts about individual exonerations: not the dates of arrest, conviction, and exoneration; not the facts of the alleged crimes; not the mode of conviction or the sentence; not the evidence of innocence that led to the exonerations; sometimes not even the names of the exonerated defendants. In short, we have too little information on many defendants in group exonerations to include them in our database of individual exonerations.

Because of these limitations, we decided in 2012 not to include group exonerations in the Registry, although we did discuss the ones we knew about in our reports. ${ }^{41}$ As of 2018, we knew of 17 such groups across the country, involving more than 2,500 exonerations, from 1990 through the present. The defendants were overwhelmingly black or Hispanic, and they were almost always framed for drug possession or distribution. ${ }^{42}$

\footnotetext{
39 See Nat'l Registry Of Exonerations, Mass Exonerations and Group Exonerations Since 1989 (Apr. 9, 2018).

40 See generally Russell Covey, Police Misconduct as a Cause of Wrongful Convictions, 90 Wash. U. L. Rev. 1133 (2013).

41 Samuel R. Gross, et.al., Race and Wrongful Convictions in the United States, 20 (Mar. 7, 2017); see also Nat'l Registry of Exonerations, Mass Exonerations and Group Exonerations Since 1989 (Apr. 9, 2018).

42 See The Nat'l Registry Of Exonerations, Mass Exonerations and Group Exonerations Since 1989 (Apr. 9, 2018).
} 
In the past two years, we have focused greater attention on the group exonerations. We plan to release a great deal of new information on them in the near future. We are expanding our focus to include some groups of convictions that were dismissed because of different types of systematic official misconduct.

In the process, we also decided that the Registry should include those individual cases within group exonerations for which we have sufficient information to know that the exoneration was the result of an individual post-conviction re-examination of the evidence in the case. We have started to re-examine group exonerations in light of this decision; so far, the cases we have considered and included are the 66 group Watts exonerations from Cook County. 43

Needless to say, all the exonerations in the Watts group, past and future, are for false convictions that were obtained by criminal misconduct by police officers-by definition. So too are thousands of exonerations, in similar groups, that have not made it onto the Registry, at least not so far; like the Watts group, they are overwhelmingly drug crime cases.

The drug frame-up group exonerations are an important illustration of a general issue: even outrageous and locally notorious misconduct in comparatively low-level cases will rarely come to our attention because few defendants in such cases are ever exonerated. What Sergeant Watts and his men were up to was well known in the neighborhoods in which they operated. In fact, other officers had reported it to their superiors years before Watts was arrested by the FBI; they were ignored and assigned to desk duty as punishment.44 It would have been much harder, perhaps impossible, to conceal an equally flagrant pattern of lying and planting evidence in murder or sexual assault cases.

In drug cases, many defendants who are framed just suck it up, plead guilty, do their time and try to move on. If the misconduct was part of a major scandal, maybe it will be discovered and, if so, maybe someday they will be exonerated. But maybe not. The first Sergeant Watts exoneration came nearly four years after he was arrested, and only because of the unusual persistence of a single defendant-Ben Baker-who managed to get help from a major non-profit innocence organization. Most cases will fall through that sort of sieve.

ii. Guilty pleas: Harris County, Texas

Since the beginning of 2006, 149 defendants have been exonerated in Harris County, Texas (home to Houston), after pleading guilty to drug possession. In all of these cases, the defendants pled guilty before the supposed drugs they possessed were tested in a crime lab, and were exonerated weeks, months or years later after testing was done and no illegal drugs were found.

${ }^{43}$ One of the 66 Watts group exonerations, that of Anthony McDaniels, was for illegal possession of a gun rather than for possession or distribution of illegal drugs.

${ }^{44}$ See infra Section XII.2.c.i(a); see also Jason Meisner, "Former Chicago Police Officer Sentenced for Stealing Money from Drug Courier," CHI. TRIB., Oct. 9, 2013. 
Why did these defendants plead guilty even though they possessed no controlled substances? Some may have had powders or pills or smoking materials that they thought were illegal drugs but were not. But as far as we can tell, most pled guilty to get out of jail.

In a typical case, the defendant had a criminal record and could not post the comparatively high bail that was set for him. If he pled not guilty, he'd remain in jail for months before trial, and then risk years in prison if convicted. It's hardly surprising that an innocent defendant in that situation would accept a deal to plead guilty and go home immediately or in a few days or weeks.

The only reason we know about these false guilty pleas is that the Harris County crime lab tests materials seized from defendants even if they have already pled guilty. Few crimes labs do that, which means that in many routine drug cases testing is never done, since more than 95\% of drug possession convictions are based on guilty pleas, many within days of arrest. Instead, dozens if not hundreds of thousands of arrests each year are based on cheap and notoriously error-prone, on-the-spot "presumptive" field tests for drugs-tests that are inadmissible in court but sufficient for arrest-and nothing more is done before the inevitable guilty pleas. 45

Even in Harris County, where post-plea lab tests were run, they had little effect for years. Sometimes the tests weren't done until long after the defendants had served their sentences. Often the paperwork notifying the prosecutor of the results was lost, misplaced or ignored. In early 2014, the Harris County District Attorney's Conviction Integrity Unit (CIU) took charge of the process and realized the magnitude of the problem. It took them four years to clear the backlog of false convictions stretching back to 2004; by then they had added 135 drug guilty plea exonerations.

These exonerations did not cover all the innocent defendants who deserved to have their convictions dismissed. As of March 2019, the Harris County DA's office had identified an additional 150 defendants who pled guilty to drug crimes and who would have been exonerated along with the rest because lab tests showed the suspected drugs contained no controlled substances-but those defendants were not located, so no court action was taken. ${ }^{46}$

The Harris County drug-possession guilty-plea exonerations are similar to the Sergeant Watts group exoneration in Cook County in one respect: a common set of facts made proof of the defendants' innocence easy. In Harris County, very easy: once a cheap, routine lab test found no illegal drugs and the results were made known to those concerned, innocence was a foregone conclusion. On the other hand, unlike the Cook County cases, nothing about the common factual basis for exoneration in Harris County suggests that the false convictions involved any sort of official misconduct. Only 2\% of the Harris County drug plea exonerations since 2014 included any known misconduct - three cases in which the authorities (probably inadvertently) failed to notify defendants that exculpatory test results had been obtained before they pled guilty.

\footnotetext{
45 Ryan Gabrielson \& Topher Sanders, How a \$2 Roadside Drug Test Sends Innocent People to Jail, N.Y. TIMES MAG. (July 7, 2016). See also Ryan Gabrielson and Topher Sanders, Busted, Propublica (July 7, 2016).

${ }^{46}$ Email from Harris County District Attorney's Office to Maurice Possley, March 7, 2019.
} 
There may have been misconduct that we don't know about in some of the Harris County drug exonerations. Two possible types, however, are racial or ethnic discrimination in the decision to stop, search or arrest suspects-"racial profiling"-and illegal searches that uncovered the supposed drugs. Neither type counts as misconduct that contributes to a factually false conviction, the type of misconduct that we are concerned with in this study. 47 As far as we know, however, official misconduct was not a significant factor in these 149 Harris County cases-and probably not in the many thousands of false convictions of other innocent drug possession defendants who plead guilty without lab tests in the rest of the country, where post-plea lab tests almost never happen.

\section{d. White-collar Crimes}

White-collar exonerations are the polar opposite of the clusters of drug cases we just discussed. There are comparatively few cases-less than $3 \%$ of all known exonerations $(63 / 2,400)$-but, with few exceptions, each was a big deal, both to prosecute and to obtain an exoneration.

In many respects, white-collar cases are more similar to murder prosecutions than to other nonviolent crimes. The crimes, of course, are extremely different from murder, and the penalties are far lighter, but the two types of cases are at least equally complex and highly important. Perhaps as a result, the rate of official misconduct among white-collar exonerations is second only to murder at $62 \%(39 / 63)$.

White-collar exonerations are also unusual in another respect: nearly three quarters were based on convictions in federal courts (46/63), compared to $3 \%$ of all other exonerations (66/2337).

As a result, we discuss white-collar cases in more detail in Section IX, which is devoted to official misconduct in federal exonerations.

\section{e. Misdemeanors}

Only $4 \%$ of exonerations in the Registry are for misdemeanors $(89 / 2,400)$, which make up at least $80 \%$ of all criminal convictions in the United States, a vast under-representation. Twothirds of misdemeanor exonerations come from among the 149 drug possession guilty-plea exonerations in Harris County, Texas (58/89). None of them include known official misconduct, for reasons we just discussed.

The remaining 31 exonerations were drawn from all misdemeanor convictions in the country other than drug possession cases in a single county. This is a tiny number, just over $1 \%$ of all known exonerations. Clearly, only an infinitesimal fraction of false misdemeanor convictions are ever pursued to the point of exoneration-unless routine but unexpected laboratory tests happen to show up and conclusively prove innocence.

\footnotetext{
47 It's possible that in some of the cases that we do count, where the materials seized included no controlled substances, police officers lied about the quantities of the substances they seized, which might have contributed to the defendants' decisions to plead guilty and hence their convictions. It's also possible, as we mentioned above, Section III.3.c.ii, that some officers lied in their reports about evidence that the defendants knowingly possessed the supposed drugs that were seized.
} 
On the other hand, $58 \%$ of these few remaining misdemeanor exonerations do include known misconduct, a higher rate of misconduct than for most types of non-homicidal felonies (18/31). Here's one:

On September 5, 2013, police in Perth Amboy, New Jersey were called to the home of 18-year-old Edwin Rodriguez by neighbors who complained that someone was riding a mini-motorcycle up and down the street. What happened next was recorded in two videos.

A police officer asked Rodriguez for identification. Rodriguez asked the officer to step outside so he could close the door while he got his ID; the officer refused. Rodriguez complained about that and began to walk up a flight of stairs; the officer tackled him and slammed him onto the steps; other officers joined in and helped subdue Rodriguez, who was pepper-sprayed, handcuffed and dragged out of the house by his ankles.

Rodriguez suffered a broken clavicle. He was charged with two counts of obstruction, resisting arrest, disorderly conduct and possession of a kitchen knife, and convicted on the last two of those counts. Rodriguez was exonerated at a retrial six months later because the judge at the first trial had excluded a video that showed, among other things, that Rodriguez was not holding a knife, and was attacked as he was trying to obtain his identification.

The few cases we have suggest that serious official misconduct-that sort we see in Edwin Rodriguez's case, or Wassillie Gregory's ${ }^{48}$ - helps generate the attention and outrage that, on rare occasions, can lead to the exoneration of an innocent misdemeanor defendant. 49

\section{RACIAL PATTERNS}

Official misconduct is more common among exonerations with Black and Hispanic defendants than those with white defendants, but only by several percentage points, as we have noted. That racial gap, however, is considerably larger for murder and drug convictions, as we see in Table 6.

48 See supra Section I.

49 See Samuel R. Gross, Errors in Misdemeanor Adjudication, 98 B.U. L. REv. 999 (2018). 
Table 6: Proportions of Exonerations with Official Misconduct by Race of Exoneree

\begin{tabular}{|cccc|c|} 
& $\begin{array}{c}\text { White } \\
\text { Exonerees }\end{array}$ & $\begin{array}{c}\text { Black } \\
\text { Exonerees }\end{array}$ & $\begin{array}{c}\text { Black \& Hispanic } \\
\text { Exonerees }\end{array}$ & $\begin{array}{c}\text { ALL } \\
\text { EXONEREES }\end{array}$ \\
\hline Murder (908) & $64 \%$ & $78 \%$ & $77 \%$ & $72 \%$ \\
\hline \multicolumn{1}{c}{$\begin{array}{l}\text { Death Sentences (121) } \\
\text { Other Murder } \\
\text { Convictions (787) }\end{array}$} & $68 \%$ & $87 \%$ & $87 \%$ & $78 \%$ \\
\hline Drug Crimes (317) & $\mathbf{6 3 \%}$ & $77 \%$ & $75 \%$ & $71 \%$ \\
\hline ALL CRIMES (2,400) & $52 \%$ & $\mathbf{4 7 \%}$ & $44 \%$ & $39 \%$ \\
\hline
\end{tabular}

Blacks are about $13 \%$ of the population of the United States, but account for $48 \%$ of all known exonerations $(1,158 / 2,400), 52 \%$ of murder exonerations (468/908) and $63 \%$ of drug crime exonerations (200/317) (and an even higher proportion of group exonerations based on drug crime frame-ups)..$^{\circ}$ There is no doubt that race plays a role in the conviction of innocent defendants in America, an issue we explored in detail in a report in 2017. ${ }^{1}$

One of the mechanisms that leads to the disproportionate conviction of innocent Black defendants is official misconduct. For murder exonerations, 78\% of exonerated Black defendants were the victims of official misconduct, compared to $64 \%$ of white defendants; among innocent murder defendants who were sentenced to death, that gap is $87 \%$ for African Americans and 68\% for whites. For drug crime exonerations, the difference is even starker. Black drug crime exonerees were more than twice as likely as whites to have been convicted in whole or in part by official misconduct, $47 \%$ compared to $22 \%$.

At least three comparatively small sets of exonerations with high rates of misconduct are racially homogeneous, or nearly so: Ninety-three percent of the child sex abuse exonerations that followed the child sex abuse hysteria (CSH) epidemic in the 1980 s and 1990 s $^{2}$ included official misconduct (54/58); $81 \%$ of the exonerees in those cases were white $(47 / 58)$ and only $3 \%$ were Black (2/58). By contrast, all of the 66 drug exonerees in the one group exoneration included in the Registry so far, the Sergeant Watts exonerations in Chicago, were Black53-and all were the victims of official misconduct. And in a very different context, the overall rate of official

\footnotetext{
50 See supra Section III.3.c.i.

51 See Samuel Gross et al, Nat'I Registry of Exonerations, Race and Wrongful Convictions in the United States (2017).

52 See infra, Section IV.4.

${ }^{53}$ See supra Section III.3.c.i. As we've mentioned, one of the exonerees in the Watts group, Anthony McDaniels, was convicted for illegal possession of a gun rather than for possession or distribution of illegal drugs.
} 
misconduct among white-collar crime exonerations is $62 \%(39 / 63)$, second only to murder; $81 \%$ of white-collar crime exonerees were white (51/63) and only 8\% were Black (5/63). 54

As used in Table 6-and in the Registry, and throughout this report-the categories "White" and "Black" do not include individuals who identify themselves as Hispanic or Latino. We do not discuss patterns in exonerations of Hispanic or Latino defendants (except in passing) because the data at our disposal are unreliable. We study convictions that occurred from the late $1960 \mathrm{~s}$ through 2018, and use records that employ inconsistent and sometimes ambiguous definitions of this ethnic group, or ignore it entirely. 55 The main problem with the data at our disposal is that we can't tell whether Hispanic defendants with African ancestry were classified as Hispanic or as Black. We can circumvent that problem by combining these two minority groups, as we do in Table 6 under the heading "Black and Hispanic Exonerees." The rates of official misconduct for the combined group are similar to those for Black exonerees alone.

\section{CATEGORIES OF MISCONDUCT}

We found many types of misconduct across these cases (and many cases with more than one type) but the great majority fall into five general categories. They are, in an order that roughly corresponds to the chronological order of criminal prosecution: Witness Tampering, Misconduct in Interrogations, Fabricating Evidence, Concealing Exculpatory Evidence, and Misconduct at Trial.

In the sections that follow, we discuss these forms of misconduct in that order. The remainder of this section is a quick overview, starting with Table 7 , which displays the proportions of cases with each sort of misconduct, by crime. Murder cases, as we already saw, have the highest overall rate of misconduct, and also the highest rate for each subcategory, except the comparatively uncommon category of Fabricating Evidence.

\footnotetext{
${ }^{54}$ Racial differences in the rates of official misconduct are smaller for the other crimes that appear most frequently among known exonerations: Sexual Assault_Black exonerees 38\% (72/191), white exonerees 44\% (46/105); Robbery-Black exonerees 39\% (29/74), white exonerees 36\% (10/28); "Other Violent Crimes"-Black exonerees $55 \%$ (55/100), white exonerees 52\% (64/122); Child Sex Abuse exonerations excluding CHS cases-Black exonerees 29\% (20/68), white exonerees 35\% (43/122).

${ }^{55}$ See Samuel Gross et al, Nat'l Registry of Exonerations, Race and Wrongful Convictions in the United States (2017), at p. 1.
} 
Table 7: Proportions of Exonerations with Misconduct by Category and by Crime

\begin{tabular}{|c|c|c|c|c|c|c|}
\hline & $\begin{array}{l}\text { Witness } \\
\text { Tampering }\end{array}$ & $\begin{array}{l}\text { Misconduct in } \\
\text { Interrogations }\end{array}$ & $\begin{array}{l}\text { Fabricating } \\
\text { Evidence } \\
\text { (estimates)* }\end{array}$ & $\begin{array}{l}\text { Concealing } \\
\text { Exculpatory } \\
\text { Evidence }\end{array}$ & $\begin{array}{l}\text { Misconduct } \\
\text { at Trial }\end{array}$ & $\begin{array}{l}\text { ALL OFFICIAL } \\
\text { MISCONDUCT }\end{array}$ \\
\hline Murder (908) & $23 \%$ & $14 \%$ & $5 \%$ & $61 \%$ & $32 \%$ & $72 \%$ \\
\hline $\begin{array}{l}\text { Child Sex } \\
\text { Abuse (270) }\end{array}$ & $28 \%$ & $3 \%$ & $3 \%$ & $27 \%$ & $14 \%$ & $44 \%$ \\
\hline $\begin{array}{l}\text { Sexual } \\
\text { Assault (320) }\end{array}$ & $12 \%$ & $4 \%$ & $9 \%$ & $32 \%$ & $17 \%$ & $39 \%$ \\
\hline Robbery (122) & $11 \%$ & $1 \%$ & 0 & $28 \%$ & $14 \%$ & $38 \%$ \\
\hline $\begin{array}{l}\text { Other Violent } \\
\text { Crimes (270) }\end{array}$ & $18 \%$ & $5 \%$ & $13 \%$ & $43 \%$ & $26 \%$ & $55 \%$ \\
\hline $\begin{array}{l}\text { Drug Crimes } \\
\text { (317) }\end{array}$ & $1 \%$ & $1 \%$ & $28 \%$ & $37 \%$ & $13 \%$ & $39 \%$ \\
\hline $\begin{array}{l}\text { White-collar } \\
\text { Crimes (63) }\end{array}$ & $14 \%$ & 0 & 0 & $48 \%$ & $30 \%$ & $62 \%$ \\
\hline $\begin{array}{l}\text { Other Non- } \\
\text { Violent } \\
\text { Crimes (130) }\end{array}$ & $5 \%$ & 0 & $4 \%$ & $28 \%$ & $15 \%$ & $32 \%$ \\
\hline $\begin{array}{l}\text { ALL CRIMES } \\
(2,400)\end{array}$ & $17 \%$ & $7 \%$ & $10 \%$ & $44 \%$ & $23 \%$ & $54 \%$ \\
\hline
\end{tabular}

* Unlike the types of misconduct reported in the other columns of this table, the percentages of cases with Fabricated Official Evidence are estimates combining information from two separate analyses of the Registry data: our analysis of all 2,400 exonerations covered in this report, and more detailed information from a study of the first 1,361 cases posted among those 2,400. See the Methodological Appendix for a full description of how these estimates were obtained.

\section{a. Witness Tampering}

In $17 \%$ of the prosecutions that ultimately led to exoneration, government officials improperly induced witnesses to provide false evidence, or to withhold accurate evidence $(409 / 2,400)$. Usually this was done by police officers, but prosecutors and child welfare workers participated in a substantial minority of the cases. There are many forms of witness tampering, but they all fall into two basic types of misconduct:

Threats. In $5 \%$ of exonerations, government officials used threats to coerce witnesses to change their testimony $(130 / 2,400)$. Witnesses were told that if they did not cooperate, they or close relatives would be charged with crimes, sentenced to prison or to death, lose custody of their children, and so forth. The witnesses who succumbed to these 
threats all knew that they were deceiving the fact finders, either by lying or by deliberately withholding evidence favorable to the defense.

Manipulation. In 13\% of exonerations, officials distorted witness testimony without using threats $(305 / 2,400)$. Some witnesses were bribed to change their testimony by promises of lenience in their own criminal cases, or received other benefits: privileges in jail, release from custody, drugs, money, etc. Others were deceived by false evidence of the defendants' guilt or tricked into thinking they saw things that did not happen. Some were simply asked to lie (or to keep the truth to themselves) and agreed to do it. Some witnesses who were manipulated into giving false testimony did not realize it; others did.

Like most categories of official misconduct, witness tampering is most common among the worst violent crimes that appear frequently in exonerations-murder (23\%) and child sex abuse (28\%) - followed by other categories of violent crimes, and is least common among non-violent crimes.

\section{b. Misconduct in Interrogations}

Twelve percent of exonerees falsely confessed to the crimes they were convicted of $(292 / 2,400)$, usually under pressure from police. Some types of pressure and deception that would be misconduct in dealing with ordinary witnesses are permitted in interrogations of criminal suspects, presumably on the theory that because guilty suspects have obvious and overwhelming motives to lie about their guilt, police must be allowed-within limits-to scare, trick and deceive them in order to get the truth. But police sometimes go beyond those limits and commit misconduct in interrogations. They did so (that we know of) in $57 \%$ of exonerations with false confessions (165/292); three-quarters of those exonerations were murder cases (126/165).

In nearly two-thirds of cases in which police misconduct led to false confessions, the police used or threatened to use physical violence (105/165). Half of all exonerations in the United States in which confessions were obtained by violence occurred in Chicago, where violence was used to obtain more than two-thirds of false confessions in exonerations (52/75); for the rest of the country, that rate was less than a quarter (53/217).

\section{c. Fabricated Official Evidence ${ }^{56}$}

In some criminal cases,, police and other law enforcement officers are themselves critical witnesses to the alleged crimes or the facts surrounding them, or claim to be. In that situation, officers don't need to tamper with witnesses in order to present false evidence against defendants-they are witnesses and can do so directly. We see this sort of misconduct in about $10 \%$ of exonerations, in three forms:

- Forensic Fraud. In about 3\% of exonerations (75/2,400) state forensic analysts (often police officers) deliberately presented false forensic evidence of the defendants' guilt. In some cases they described tests or observations they never made; in others they claimed

${ }^{56}$ See supra Table 7, and infra Methodological Appendix. 
without justification that the defendants' hair or blood or semen "matched" items from the crime; and in some they testified that the defendant could have been or was the source of biological trace evidence after testing had already shown that was impossible.

- Fake Crimes. In about 4\% of exonerations, police officers planted incriminating physical evidence on suspects or at the scene of the crime-usually drugs-or booked the evidence and falsely claimed it was found on the suspects. In about $1 \%$ of additional cases, police officers falsely testified that they themselves had been assaulted by the defendants, usually to cover up their own violence.

- Fictitious Confessions. In close to $2 \%$ of exonerations, police officers testified that defendants had confessed when they had not $(36 / 2,400)$.

Fabricating evidence is most common among exonerations for those crimes that are defined by the types of evidence that are fabricated: (planted) drug crimes, and (fake) criminal assaults.

\section{d. Concealing Exculpatory Evidence}

In $44 \%$ of exonerations $(1,064 / 2,400)$, law enforcement officials concealed evidence favorable to the defendant. This is the most common type of official misconduct we found. It is done by prosecutors and police officers alike. Two basic categories of exculpatory evidence were concealed:

- Substantive evidence of innocence. In 30\% of exonerations, law enforcement officials concealed substantive evidence that would have supported the defendants' claims of innocence $(709 / 2,400)$. The hidden evidence included alibi evidence for the defendant, evidence about alternative suspects (some of whom were later proven to be the real criminals), forensic evidence that showed that the defendant was not the source of semen or blood or fingerprints left at the scene of the crime, and so forth.

- Impeachment evidence. In an overlapping third of the cases, police and prosecutors concealed evidence that would have undercut witnesses who testified to the defendants' guilt $(805 / 2,400)$. They hid statements in which prosecution witnesses said the opposite of what they testified to in court, attempts by those witnesses to retract their accusations or testify that the defendants were innocent, known histories of deception and crime by prosecution witnesses, money or favors received by the witnesses or deals that saved them years in prison in return for nailing the defendants, and so on. ${ }^{57}$

Concealing exculpatory evidence is widespread across the board. It occurred in $27 \%$ to $48 \%$ of exonerations for every category of non-homicidal crime. But it is uniquely prevalent in exonerations for murder, where it occurred in $61 \%$ of all cases.

${ }^{57}$ Nineteen percent of the cases included both types of concealed exculpatory evidence $(450 / 2,400)$. 


\section{e. Misconduct at Trial}

Criminal convictions in the United States are overwhelmingly obtained by guilty pleas, but 80\% of exonerated defendants were convicted at trial $(1,928 / 2,400)$. About $28 \%$ of those trials (546/1928)-23\% of all exonerations $(546 / 2,400)$-included official misconduct in court, in the course of the trial.

- Police Perjury. Police and other law enforcement officers testify in almost all criminal trials, and sometimes they lie. That happens-that we know of-in more than $14 \%$ of exonerations after conviction at trial, or $13 \%$ of all exonerations.

Some of those cases were discussed above under Fabricating Official Evidence; they involved forensic fraud or officers who falsely claimed to have witnessed or been victimized by crimes by the exonerees. However, in three quarters of trials with police perjury, officers lied about the conduct of the investigations, or about statements by other witnesses rather than their own observations.

- Trial misconduct by prosecutors. Prosecutors committed misconduct at trial in more than $14 \%$ of all exonerations (334/2,400). The great majority of this courtroom misconduct fell into three categories: 58

○ Knowingly permitting perjury. In 8\% percent of exonerations, prosecutors knowingly permitted witnesses to commit perjury at trial without notifying the court $(186 / 2,400)$.

- Lying in court. In about $4 \%$ of exonerations a prosecutor lied to the court about the facts of the crime the defendant was charged with, or about the investigation and prosecution of the case $(94 / 2,400)$ - usually in closing argument.

- Improper statements in closing argument or cross-examination. In more than $3 \%$ of exonerations prosecutors made improper, often unconstitutional closing arguments to the juries or judges that convicted the defendants $(77 / 2,400)$ - not counting the cases in which prosecutors lied directly in argument, which are covered by lying in court. The most common improper arguments (other than outright lies) were factual claims that had no basis in the evidence presented, and arguments that a defendant who did not testify in her own defense must be guilty because she did not deny it in court. In about $1 \%$ of cases (that we know of) prosecutors made equally improper statements in the guise of questions on crossexamination $(26 / 2,400)$.

\footnotetext{
58 More than a third of cases with official misconduct at trial involved multiple forms of misconduct (121/334).
} 


\section{GENERAL PATTERNS IN WITNESS TAMPERING}

As we've noted, $5917 \%$ of the exonerations in the Registry include witness tampering $(409 / 2,400)$, by threats $(5 \%)$ or manipulation $(13 \%)$ or occasionally both (1\%). Table 8 displays the rates of witness tampering by crime and category-threats or manipulation.

Table 8: Witness Tampering by Category and Crime*

\begin{tabular}{lcccc|c} 
& $\begin{array}{c}\text { Murder } \\
(908)\end{array}$ & $\begin{array}{c}\text { Sexual } \\
\text { Assault } \\
(320)\end{array}$ & $\begin{array}{c}\text { Child Sex } \\
\text { Abuse } \\
(270)\end{array}$ & $\begin{array}{c}\text { Other } \\
\text { Crimes } \\
(902)\end{array}$ & $\begin{array}{c}\text { ALL } \\
\text { CRIMES } \\
(2,400)\end{array}$ \\
\hline Threats & $10 \%$ & $1 \%$ & $9 \%$ & $1 \%$ & $5 \%$ \\
\hline Manipulation & $16 \%$ & $11 \%$ & $20 \%$ & $8 \%$ & $13 \%$ \\
$\begin{array}{l}\text { ALL WITNESS } \\
\text { TAMPERING }\end{array}$ & $23 \%$ & $12 \%$ & $28 \%$ & $9 \%$ & $17 \%$ \\
\hline
\end{tabular}

* Some cases include both witness tampering with and without threats.

Witness tampering by the authorities is unevenly distributed across crimes. The rates are highest for murder, $23 \%$, and child sex abuse, $28 \%$, compared to $12 \%$ for sexual assaults and $9 \%$ for all other crimes. Almost 80\% of all exonerations with witness tampering are murder, sexual assault or child sex abuse cases (325/409). Witness tampering by threats is even more concentrated. More than $89 \%$ of exonerations with this form of tampering are for murder or child sex abuse (116/130), which may reflect heavy commitments of time and attention to alleged victims of child sex abuse, and to witnesses of all sorts in murder investigations.

In Table 9, we see that witness tampering is primarily a form of police misconduct. For this table and Table 10, we rely on data from a detailed study of official misconduct among the 1,361 exonerations posted on the Registry by May 16, 2014, that includes information on the positions of the officials who committed each type of misconduct, data that are not available for the entire 2,400 case database. ${ }^{60}$ Police officers tampered with witnesses in $80 \%$ of the exonerations in which that happened (206/259), whether by threats or by manipulation $-75 \%$ more than the total for prosecutors and child welfare workers combined. This is no surprise; police officers are the main investigators who find and interview witnesses, and take statements from them.

\footnotetext{
59 Supra Section III.5.a.

${ }^{60}$ See supra Section II.2.a.
} 
Table 9: Witness Tampering by Category and Responsible Party* $(n=1,361)$

\begin{tabular}{lccc|c} 
& Police Officer & Prosecutor & Child Welfare Worker & \multicolumn{1}{c}{ ANY STATE OFFICIAL } \\
\hline Threats & $5 \%(67)$ & $\mathbf{2 \% ( 2 7 )}$ & $\mathbf{1 \% ( 1 4 )}$ & $6 \%(80)$ \\
\hline Manipulation & $11 \%(144)$ & $4 \%(57)$ & $2 \%(23)$ & $14 \%(189)$ \\
\hline ALL WITNESS & $15 \%(206)$ & $6 \%(80)$ & $3 \%(37)$ & $19 \%(259)$ \\
\hline TAMPERING & & &
\end{tabular}

* Some cases include misconduct by more than one type of official.

We have identified three common types of witness tampering, one or more of which occurred in $78 \%$ of exonerations that include this category of misconduct (319/409). All three can be accomplished by threats or by manipulation or both:

- Procuring false testimony is the practice of inducing a civilian witness to testify to facts the officer or prosecutor knows the witness did not perceive.

- A tainted identification occurs when police deliberately induce a witness to identify a suspect during a lineup or other identification procedure, whether the witness recognizes that suspect or not.

- Improper questioning of a child victim is repeated, insistent and suggestive questioning of a child by a government official who will not allow the child to deny that he or she was a victim of sex abuse.

We discuss these types of tampering in more detail in the sections that follow-after a quick review of a couple of general patterns:

Table 10: Proportions of Cases with Witness Tampering by Responsible Party* ( $\mathrm{N}=1,361)$

\begin{tabular}{lccc|c} 
& $\begin{array}{c}\text { Police } \\
\text { Officer }\end{array}$ & Prosecutor & $\begin{array}{c}\text { Child Welfare } \\
\text { Worker }\end{array}$ & $\begin{array}{c}\text { ANY STATE } \\
\text { OFFICIAL }\end{array}$ \\
\hline $\begin{array}{l}\text { Procuring False } \\
\text { Testimony }\end{array}$ & $3 \%(41)$ & $3 \%(41)$ & $0 \%(0)$ & $6 \%(77)$ \\
\hline $\begin{array}{l}\text { Tainted } \\
\text { Identification }\end{array}$ & $7 \%(91)$ & $0.1 \%(2)$ & $0 \%(0)$ & $7 \%(91)$ \\
\hline $\begin{array}{l}\text { Improper } \\
\text { Questioning } \\
\text { of a Child Victim }\end{array}$ & $3 \%(42)$ & $1 \%(16)$ & $3 \%(37)$ & $4 \%(50)$ \\
\hline
\end{tabular}

* Some cases include misconduct by more than one type of official.

Table 10 displays the frequency of each type of witness tampering by the type of government official who did it, and shows how police led the field: 
- Police and prosecutors procured false testimony in equal numbers of cases, but child welfare workers never did so.

- Police and child welfare workers engaged in improper questioning of children at about the same rate, but prosecutors did so much less frequently.

- Police conducted all tainted identifications, with prosecutors also participating in two of them.

Table 11 shows that these subspecies of witness tampering are unevenly distributed across categories of crime. Procuring false testimony was far more common in exonerations for murder than for lesser crimes; abusive questioning of children occurred exclusively in child sex abuse exonerations; and tainted identifications were most common in exonerations for sexual assault followed closely by murder exonerations.

Table 11: Proportions of Cases with Witness Tampering by Category and Crime

\begin{tabular}{lcccc|c|} 
& $\begin{array}{c}\text { Murder } \\
(908)\end{array}$ & $\begin{array}{c}\text { Sexual } \\
\text { Assault } \\
(320)\end{array}$ & $\begin{array}{c}\text { Child Sex } \\
\text { Abuse } \\
(270)\end{array}$ & $\begin{array}{c}\text { Other } \\
\text { Crimes } \\
(902)\end{array}$ & $\begin{array}{c}\text { ALL CRIMES } \\
(2,400)\end{array}$ \\
\hline $\begin{array}{l}\text { Procuring False } \\
\text { Testimony }\end{array}$ & $11 \%$ & $1 \%$ & $1 \%$ & $5 \%$ & $6 \%$ \\
\hline $\begin{array}{l}\text { Tainted Identification } \\
\text { Tainter }\end{array}$ & $9 \%$ & $9 \%$ & $1 \%$ & $4 \%$ & $6 \%$ \\
\hline $\begin{array}{l}\text { Improper Questioning } \\
\text { of a Child Victim }\end{array}$ & $0 \%$ & $0 \%$ & $24 \%$ & $0 \%$ & $3 \%$ \\
\hline $\begin{array}{l}\text { ALL WITNESS } \\
\text { TAMPERING }\end{array}$ & $23 \%$ & $12 \%$ & $28 \%$ & $9 \%$ & $17 \%$ \\
\hline
\end{tabular}

\section{PROCURING FALSE TESTIMONY}

Procuring perjury is an extreme form of misconduct. It only occurs in about $6 \%$ of all exonerations; two-thirds of them are murder cases-the most serious cases, where the pressure is greatest and the stakes highest. The Randall Dale Adams exoneration is a clear example:

Adams's car ran out of gas on November 27, 1976. He was walking along the side of the road when 16-year-old David Harris offered him a ride. Later that night (when Adams was no longer with him), Harris shot and killed a police officer. Once Harris became a suspect, he claimed that Adams was driving at the time and shot the officer with Harris's gun, while Harris himself was in the front passenger seat.

There was no evidence connecting Adams to the shooting other than Harris's testimony, and Harris had been a suspect himself, so the police needed credible eyewitness testimony to make the case. One eyewitness described the shooter as 
Black or Mexican, and failed to identify Adams (who was white) in a lineup. The police offered to drop pending robbery charges against the witness's daughter if she would change her statement and make the identification. She agreed. Her original description and her failure to identify Adams were concealed.

At trial, that witness testified that she identified Adams unassisted, a claim that the prosecution knew was a lie. Adams was convicted and sentenced to death in 1977.

Almost ten years later a filmmaker who was making a documentary about Adams' case discovered the hidden history of this eyewitness identification, and learned about Harris's subsequent criminal history. Among other crimes, Harris had committed another murder for which he too had been sentenced to death.

At a hearing in 1988, Harris recanted his testimony. Adams was exonerated in 1989. Harris was executed in 2004.

In some cases, the process of procuring false testimony is simpler but no less damaging. In 2012, for example, the Texas Court of Criminal Appeals concluded that Richard Miles had proven his innocence of the murder for which he was convicted in Dallas in 1995. Part of the basis for that decision was new evidence that before Miles's trial, the key eyewitness "was unable to identify the shooter, and when he told the State of this fact, the prosecutor directed him to identify [Miles] by showing him where [Miles] would be seated in the courtroom." 61 And in Clarence Brandley's case in Montgomery County, Texas, in 1981, the officer investigating the murder of a high school student told the two custodians who found the body, "One of you is going to have to hang for this" and, turning to Brandley, added, "Since you're the nigger, you're elected." To make that promise stick, that officer later told a witness who saw another suspect near the scene of the crime that he would be arrested if he said anything inconsistent with Brandley's guilt.

In other cases, the perjury is the culmination of a long process of abuse and corruption.

In 1968 Peter Limone, Louis Greco and Henry Tameleo were convicted of murdering Edward Deegan, a small-time criminal, three years earlier in an organized crime hit in Boston. Their conviction was based on testimony from a gangster named Joseph "The Animal” Barboza, who testified that he participated in the murder, and that it was ordered by Limone, approved by Tameleo and carried out by Greco. All three were sentenced to death, later reduced to life imprisonment. A fourth defendant, Joseph Salvati, was convicted as an accessory and sentenced to life.

In 2000, a special prosecutor came across numerous documents that painted the real picture: Barboza was an FBI informant in 1965; FBI agents knew that he planned to kill Deegan and allowed the murder to take place in order to protect his position as an informant; the FBI knew that Greco, Limone, Tameleo or

${ }^{61}$ Ex Parte Miles, 359 S.W.3d 647, 661 (Tex. Crim. App. 2012). 
Salvati had nothing to do with that murder; nonetheless, the FBI used Barboza's perjury to convict Limone, Greco, Tameleo and Salvati. All four were exonerated in 2001; by then Greco and Tameleo had died in prison.

\section{TAINTED IDENTIFICATIONS}

Many identification procedures are poorly designed. They can lead to terrible mistakes and cause false convictions, but these are not usually "tainted" identifications. In Timothy Cole's rape investigation in Lubbock, Texas in 1985, for example, police showed the victim six color photographs: the five "fillers" were standard police mugshots, all in profile-but no mugshot was available for Cole, who had never been arrested, so an officer took a Polaroid picture of him, facing the camera.

Suggestive identification procedures like Cole's are common. ${ }^{62}$ They are bad police practice, and (as a wealth of research has shown ${ }^{63}$ ) they cause false convictions. In this case, the victim picked out Cole immediately. Cole died in prison 13 years later, 10 years before he was exonerated, posthumously, by DNA testing and a confession from the actual rapist.

Despite such outcomes, using a suggestive identification procedure is not misconduct unless the police intentionally structured the identification to induce the witness to identify the exoneree. We have no evidence of that sort of deliberate behavior in Cole's case. What the officers did may have been just as harmful all the same, but it was incompetence not misconduct.

Police (and in a few rare cases, prosecutors) cross the line when they tell witnesses in one form or another who to identify. Sometimes they do it indirectly:

Thomas Doswell was identified by a rape victim in Pittsburgh who was shown photographs of eight men, one of which-Thomas's-had the letter "R" (for rapist) written on it. He was exonerated by DNA 19 years later.

In 1985, Nathson Fields, a member of the El Rukn street gang in Chicago, was misidentified by members of a rival gang as one of two men who gunned down two their comrades the previous year. Fields was the only person in the lineup wearing short sleeves, which showed an El Rukn tattoo on his forearm.

\footnotetext{
62 We don't know how common suggestive procedures are in the investigations of exonerated defendants because in most cases we have don't know enough about police initiated identifications. If we had video and audio recordings of the process, and copies of any pictures shown to victims and witnesses, we might be able to assess the suggestiveness of the procedures, but usually we don't. Without that sort of record, we are limited to the cases in which suggestiveness was noticed and raised in court. Unfortunately, the defense attorneys who might raise the issue often have no better information than we do, and some are too ineffective to act on any information they do have.

63 See National Research Council of the National Academy of Sciences, Identifying the Culprit: Assessing Eyewitness Identification (2014); National Registry of Exonerations, Tainted Identifications (2016); Steven P. Grossman, Suggestive Identifications: The Supreme Court's Due Process Test Fails to Meet Its Own Criteria, 11 U. Balt. L. Rev. 53 (1981).
} 
In other cases, the police are more straightforward. Michael VonAllmen was identified by a rape victim in Louisville, Kentucky after a police officer told her that VonAllmen had already been identified by five or six other rape victims but had not been charged because those women were too scared to testify. And in Jerry Lee Evans's case, Dallas police simply told the victim which picture to choose.

Tainted identifications were used twice as frequently in exonerations with minority defendants as in those with white defendants: Black defendants, 7\% (86/1158); Black or Hispanic defendants, ${ }^{64} 8 \%(113 / 1,439)$; white defendants, $4 \%$ (34/906). This contributes to the high rate of false sexual assault convictions of innocent Black men who were charged with sexual assaults on white women. 65

Many victims who are directly told who to identify, and comply, know that they are lying-that they did not themselves recognize the defendants-but they may also believe that the men they accuse are, in fact, guilty. On the other hand, when police officers indicate the suspect indirectly, some eyewitnesses may think they are identifying a person they saw and recognize. Walter

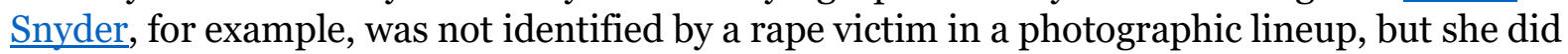
identify him in a live lineup after Alexandria, Virginia police asked her to come to the police station, and arranged for her to see Snyder waiting by himself in the lobby. ${ }^{66}$

Three-quarters of the tainted identifications that we know about occurred in murder and sexual assault cases (112/149). The rate of tainted identifications is the same for both crimes-9\% (see Table 11)-but the underlying behavior is entirely different.

In nearly $80 \%$ of murder cases with tainted IDs, one or more witnesses deliberately misidentified the exonerees $(65 / 82)$, while only half included any witnesses who mistakenly identified them (41/82). In 35\% of those cases, police got witnesses to identify the defendants by threatening rather than manipulating them (29/82); all but one included deliberate false identifications of the exonerees. For example:

A year after Charles Wilhite was convicted of murder in Springfield, Massachusetts in 2010, the critical eyewitness testified that a detective repeatedly threatened to charge him as an accessory to the murder if he didn't identify Wilhite-who was acquitted at a retrial in 2013.

When Mubarez Ahmed was convicted of murder in Detroit in 2001, the critical eyewitness was Izora Clark. In closing argument, the prosecutor told the jury, "If you don't believe Ms. (Clark), you have to find him not guilty.” Fifteen years later, Clark told defense attorneys and later the prosecutor's office that she had not

\footnotetext{
64 See supra, Section III.4, Table 6.

65 See Samuel Gross et al, Nat'l Registry of Exonerations, Race and Wrongful Convictions in the United States (2017), at pp. 11-12 ("In half of all sexual assault exonerations with eyewitness misidentifications, black men were convicted of raping white women, a racial combination that appears in less than $11 \%$ of sexual assaults in the United States.").

${ }^{66}$ Barry Scheck, Peter Neufeld \& Jim Dwyer, Actual Innocence, 53-100 (2001).
} 
seen Ahmed at the shooting, and that she only identified him because she was intimidated by the police and afraid that if she didn't do what they said they would retaliate against her son, who was incarcerated at the time.

In sexual assault exonerations the victims always survive the crimes because if a victim is killed, the case becomes a murder. Unlike murder prosecutions, the critical eyewitness in a sexual assault case is almost always the victim. Perhaps for that reason, none of the tainted identifications in sexual assault exonerations include threats by the police, and all but one produced mistaken witness identifications (28/29).

Police may trick or persuade some rape victims to identify suspects they did not in fact see, but, as best we can tell, they don't force them to lie about whether they were attacked or by whom. In Garry Diamond's case, for example, the victim failed to pick Diamond's picture from a mug book of police photographs-and when her three-year-old son pointed to him, said the child was mistaken because Diamond had the wrong hair color, eye color and complexion. She later failed to identify Diamond from a photograph again. Three months later, however, she did identify Diamond in person-when a detective brought her to court to see Diamond on trial for an unrelated sexual assault. Diamond was convicted in 1976 in Virginia, and exonerated by DNA 36 years later.

While we know of no adult sexual assault exonerations in which police or prosecutors threatened victims to get them to identify the defendants, ${ }^{67}$ they have done just that to the supposed victims in some child sex abuse cases-as we see in the next section.

\section{IMPROPER QUESTIONING OF A CHILD VICTIM}

In some child sex abuse investigations, police officers, child welfare workers and occasionally prosecutors have engaged in prolonged, improper and in many cases abusive questioning of the children who were the supposed victims of the alleged crimes. This happened, that we know of, in nearly a quarter of child sex abuse exonerations (see Table 11). Nearly 80\% of exonerations with this type of misconduct were part of an epidemic child sex abuse hysteria that swept across the country from the early 1980 s to the late 1990 (49/64). Most of those cases were based on accusations against child daycare providers and many included allegations of satanic rituals. Eventually, at least 70 innocent defendants were convicted of child molestation and other serious felonies, many others were arrested and charged. ${ }^{68}$

Many of the accusations the children made in response to this sort of questioning were bizarre if not impossible on their face. Children at the Little Rascals Day Care Center in Edenton, North Carolina, said that they had seen babies killed, children taken out on boats and thrown overboard to feed sharks, and children taken to outer space in a hot air balloon. ${ }^{69}$ In Kern

\footnotetext{
67 In a few exonerations that included sexual assaults as well as other violent crimes, police threatened witnesses other than the rape victims and forced them to identify the exonerees.

68 See Samuel R. Gross \& Michael Shaffer, Exonerations in the United States, 1989 - 2012, at 75-78, National Registry of Exonerations (2012).

69 Innocence Lost, Frontline, Public Broadcasting Service (1997).
} 
County, California, children described mass orgies with as many as 14 adults who forced groups of children to inhale 18-inch lines of cocaine or heroin, gave them injections with syringes that left large bruises, and hung the children from hooks as the adults repeatedly sodomized them. ${ }^{70}$ Needless to say, no physical evidence ever corroborated any of these claims.

And in Wenatchee, Washington, ${ }^{71}$ in 1994 , police arrested 43 people on charges that they had molested 60 children 29,726 times over a six-year period. That's an average of more than 100 sexual assaults a year for each abuser, and nearly 500 apiece for each of the 60 children-but somehow nobody in a town of 55,000 residents noticed anything at the time.

In other cases, the accusations were merely implausible. Either way, they appear to have been generated by over-eager police officers and child welfare workers who insisted that the children tell them that they had been molested, and would not take No for an answer.

The Registry includes 58 defendants who were exonerated in child sex abuse hysteria cases across the country, $84 \%$ of which included improper questioning of children (49/58). ${ }^{72}$ All of these exonerees were convicted between 1984 and 1998 (and all but a handful, by 1995).

And then the epidemic passed. We know of no more recent convictions of that sort in which claims of innocence are pending. A case from Minnesota that did not result in a conviction illustrates the change. 73

In 1984, a psychiatrist in Minnetonka, Minnesota, interviewed four-year-old Aubree LaBois about her parents, Edward and Karri LaBois, who ran a daycare center. The psychiatrist asked Aubree leading questions about sex abuse at the center and showed her "anatomically correct" dolls to illustrate the questions; Aubree eventually agreed that she had been sexually molested by her parents.

At first Edward and Karri LaBois denied allegations of sex abuse at their daycare center. But when they heard that the authorities were planning to take Aubree away, they took her and fled. In 2003, 19 years later, they were found in Salt Lake City and arrested-and then all charges were dismissed within two weeks.

Aubree-by then 23 and a mother herself-denied she had ever been molested, and said she had been misled and confused by the psychiatrist who interviewed her when she was four. Her statements from 1984 were now seen as "conflicting" and unreliable, and fresh

\footnotetext{
70 Debbie Nathan \& Michael Snedeker, Satan's Silence: Ritual Abuse And The Making of a Modern American Witch Hunt (1995).

71 See here for all 11 Wenatchee exonerations.

72 Dozens of others who had been sentenced to years or decades in prison were released without exonerations, typically after pleading guilty to lesser crimes.
}

$73 \mathrm{~J}$. Adams and M. Zack, Once fugitives, couple are freed; charges of child sex abuse against the couple dating from 1984 were dropped, Minneapolis Star Tribune, Nov. 26, 2003 at 1A; Matt Canham \& Rhonda Hailes Maylett, Life on the Lam, The Salt Lake Tribune, Dec. 14, 2003, Page A. 
interviews with other children from the daycare center (now grown up) and with their parents produced no evidence of abuse. As the Minnetonka police chief explained, interviews with children were "less sophisticated in 1984" when interrogators often used leading questions and adult sex-abuse terminology.

The children in these cases were usually questioned by police (45/53) or child welfare workers, typically social workers (37/53), or both. See Table 10. How did they get the children to make such false and often fantastical accusations? In 2005, a 30-year-old man who had testified as a nine year-old in a massive child sex abuse hysteria case that ultimately ended with no convictions, told the story of his role:

"It was an ordeal. I remember thinking to myself, 'I'm not going to get out of here unless I tell them what they want to hear.' ...

"I remember telling [the investigators] nothing happened to me. I remember them almost giggling and laughing, saying, 'Oh, we know these things happened to you. Why don't you just go ahead and tell us? Use these dolls if you're scared.'

"Anytime I would give them an answer that they didn't like, they would ask again and encourage me to give them the answer they were looking for. It was really obvious what they wanted....

"Maybe some things did happen. Maybe some kids made up stories about things that didn't really happen, and eventually started believing they were telling the truth. ... But I never forgot I was lying." 74

We don't doubt that the officers and social workers who conducted these investigations believed that the sexual assaults they charged had actually occurred, even if some of the reported facts were fanciful. They believed they were rooting out terrible hidden crimes. They had been trained and told that many victims of child sex abuse need to be helped, if not pushed, to admit that these shameful scary things ever happened to them. They accepted a then-prevalent dogma that while children often deny the occurrence of sexual assaults that did happen, they never make up ones that have no basis in fact.

We classify the questioning of a child witness as misconduct if it violates contemporary normseven though, as the Minnetonka police chief explained, practice has changed radically from the "less sophisticated" interviews with children that were routinely conducted 30 years ago.

About a fifth of exonerations with improper questioning of children are not child sex abuse hysteria cases (15/64)-including several in which the improper questioning occurred well after that epidemic was over. For example, Michael Washburn was convicted in 2002 of raping a three-year-old girl in Massachusetts nine years earlier. At trial, the girl-by then 12-admitted that a police officer had promised her "presents" if she named the person who touched her, and

\footnotetext{
${ }^{74}$ Kyle Zirpolo, as told to Debbie Nathan, I'm Sorry; A Long-Delayed Apology from One of the Accusers in the Notorious McMartin Pre-School Molestation Case, Los Angeles Times, Oct. 30, 2005, at MM10.
} 
said she would never see her father again if she didn't. Washburn was exonerated in 2003 by medical evidence that undermined the claim that the girl had been raped. 
In Section VI, on fabricated evidence, we discuss 36 false confessions by exonerees that were obtained by a different type of misconduct: making things up. These are cases in which police reported "confessions" the exonerees never made; instead police officers lied and said they did. Fourteen of those cases include misconduct in interrogation. We include those cases in this Section as well because (as we explain in Section VI) misconduct in interrogation and fabrication cannot always be neatly separated. In some cases the coercive interrogation was part of the process of fabrication, and in a few the police obtained actual false confessions and "improved" upon them by adding fabricated ones as well.

\section{a. Misconduct and permissible interrogation techniques}

Frank Sterling did not want to confess. He had maintained his innocence through several interrogations. So, three years after the crime, Sterling's interrogators lied to him about the evidence against him, administered a lie detector test that was rigged to make him appear to fail, showed him pictures of the body and crime scene, and fed him details of a killing he knew nothing about. They videotaped the 20-minute-long confession Sterling eventually gave, but they did not record the interrogation that led to that confession. These tactics are known to increase the risk of false confessions, 75 but they are not considered misconduct.

In August 2006, a 70-year-old man was found shot dead in his car in an apparent robbery in New Haven, Connecticut. A suspect was arrested, and claimed he committed the crime with 16-year-old Bobby Johnson. Johnson was picked up, told police he had been at a pharmacy at the time of the shooting, and was released. A few days later, detective Clarence Willoughby, who claimed a " $100 \%$ success rate" in solving homicides, joined the investigation, and Johnson was brought back for extended questioning, without his parents.

Willoughby threatened Johnson with the death penalty if he didn't confess, and promised him probation if he did. He told Johnson that unless he confessed he would never see his family again, and that the police had physical evidence tying him to the crime-which was a lie. Johnson ultimately gave a tape-recorded confession, which he practiced with the officers before they turned on the recorder. A few days later, ballistics tests showed that Johnson's confession was inconsistent with physical evidence, so officers told him he had to "correct" his statement or his "deal" for probation would be revoked-and Johnson made a second "revised" taped confession.

Johnson pled guilty to murder and was sentenced to 38 years. He was exonerated in 2015, after Detective Willoughby was caught extracting other false confessions

75 See Saul M. Kassin et al., Police-Induced Confessions: Risk Factors and Recommendations, 34 Law \& Hum. Behav. 13 (2010); Richard A. Leo, False Confessions: Causes, Consequences, and Implications, 37 J. Am. Acad. Psychiatry \& L. 332, 332-34 (2009). See generally Trainum, James L. How the Police Generate False Confessions: An Inside Look at the Interrogation Room. Rowman \& Littlefield Publishers; Jerome H. Skolnick \& Richard A. Leo, The Ethics of Deceptive Interrogation, 11 Crim. Just. Ethics 3, 5-8 (1992). 
and false witness statements, and new evidence implicated another man in the murder.

Bobby Johnson's interrogation-unlike Frank Sterling's-was rife with misconduct. The police pretended to "plea bargain" with Johnson (which only prosecutors may do), they lied about the law that governs the case (Johnson, as a juvenile, was not eligible for the death penalty ${ }^{76}$ ), and they threatened to never let him see his family again. These tactics are all prohibited and can (at least in theory) lead to sanctions against police officers and exclusion of confessions from evidence.

\section{b. The frequency of false confessions, in Chicago and elsewhere}

False confessions are not easy to obtain. That's true of all confessions that are not volunteered: persuading and manipulating a suspect to confess to serious crimes is a time-consuming and "expensive procedure [that] is generally reserved for the most serious cases where there is no other evidence sufficient to convict-which usually means a murder with no surviving eyewitnesses."77 It works. Many reluctant defendants confess to crimes they committed. But it also produces a steady trickle of false confessions. They occurred in $12 \%$ of known exonerations (292/2,400), mostly in murder cases, where the rate of false confessions is nearly four times that of other exonerations, $22 \%$ vs. $6 \%$. Overall, almost $70 \%$ of false confessions in known exonerations are for murder (204/292). See Table 12.

Table 12: Proportion of Exonerations with False Confessions, in Chicago and Elsewhere

\begin{tabular}{lcc|c} 
& $\begin{array}{c}\text { Exonerations } \\
\text { in Chicago }\end{array}$ & $\begin{array}{c}\text { Exonerations } \\
\text { Elsewhere }\end{array}$ & $\begin{array}{c}\text { ALL } \\
\text { JURISDICTIONS }\end{array}$ \\
\hline Murder & $\begin{array}{c}54 \% \\
(64 / 118)\end{array}$ & $\begin{array}{c}18 \% \\
(140 / 790)\end{array}$ & $\begin{array}{c}22 \% \\
(204 / 908)\end{array}$ \\
\hline All other Crimes & $\begin{array}{c}10 \% \\
(11 / 112)\end{array}$ & $\begin{array}{c}6 \% \\
(77 / 1380)\end{array}$ & $\begin{array}{c}6 \% \\
(88 / 1492)\end{array}$ \\
\hline ALL CASES & $\begin{array}{c}33 \% \\
(75 / 230)\end{array}$ & $\begin{array}{c}10 \% \\
(217 / 2,170)\end{array}$ & $\begin{array}{c}12 \% \\
(292 / 2,400)\end{array}$ \\
\hline
\end{tabular}

Table 12 also displays another basic fact about false confessions in the United States: the rate among exonerations in Chicago (Cook County), Illinois, is more than three times the rate elsewhere. Among murder exonerations in Chicago, it's an astounding 54\%. Chicago produced a quarter of all false confessions in exonerations in the nation (75/292); false convictions for

\footnotetext{
76 Roper v. Simmons, 543 U.S. 551 (2005).

77 Samuel R. Gross et al., Exonerations in the United States, 1989 Through 2003, 95 J. Crim. L \& Criminology 523, 544-45 (2005).
} 
murder in Chicago account for $22 \%$ of all false confessions we know of. As Peter Neufeld put it, "what Cooperstown is to baseball, Chicago is to false confessions. It's the Hall of Fame."78

\section{WHAT COUNTS AS COERCIVE MISCONDUCT IN AN INTERROGATION?}

From the 1940s through 1960s the Supreme Court developed the doctrine that police behavior that is so "coercive" that it makes a confession "involuntary" violates the due process clause of the Fourteenth Amendment and requires the exclusion of the confession from evidence. ${ }^{79}$ Over the decades, the Supreme Court and lower courts have identified several specific types of misconduct that may make confessions inadmissible because they are deemed "involuntary."

In 1953, in Stein v. New York, for example, the Court made clear that the use of violence, or the threat of imminent violence, automatically requires exclusion of any resulting confession. ${ }^{80}$ For other types of misconduct, courts weigh the "totality of [the] circumstances" 81 and determine on a case-by-case basis whether the confession was "involuntary" enough that its use in evidence against the suspect violates due process. ${ }^{82}$

For example, in Rogers $v$. Richmond the Court weighed the impact of the officers' threats to arrest the suspect's sick wife, concluded that such threats to a relative of the suspect may have produced an involuntary confession, and remanded the case to a lower court to decide that issue. ${ }^{83}$

In other cases, courts have condemned sham plea bargaining by police officers who pretend that they can and will obtain lenient sentences, or a reduction or outright dismissal of charges, in return for confessions. ${ }^{84}$ Sham plea bargaining is a form of lying about the law-in that context, lying about the legal authority of the police, who claim to be able to do things only prosecutors or judges can do. Lying about the law is not permitted and may contribute to a finding that a confession is involuntary, ${ }^{85}$ but vague promises of better treatment if a suspect

\footnotetext{
7860 Minutes: Chicago: The False Confession Capital (CBS television broadcast Dec. 19, 2012).

79 See Rogers v. Richmond, 365 U.S. 534, 540-41 (1961).

80 Stein v. New York, 346 U.S. 156, 182 (1953). On the other hand, scaring a suspect by telling him that he is likely to be a victim of sexual assault in the future if he is imprisoned does not automatically make a confession inadmissible, but may contribute to a finding of involuntariness. See e.g., Little v. United States, 125 A.3d 1119, 1127-28 (D.C. 2015).

81 See, e.g., Haynes v. Washington, 373 U.S. 503, 513-14 (1963).

82 ld. at 514.

83 Richmond, 365 U.S. at 543-44.

84 See State v. Howard, 825 N.W.2d 32, 41 (lowa 2012); see also Commonwealth v. Magee, 668 N.E.2d 339, $344-45$ (Mass. 1996).

85 State v. Walker, 493 N.W.2d 329, 334-35 (Neb. 1992).
} 
confesses are not misconduct, ${ }^{86}$ and lying about the evidence the police have against the suspect is permitted and routine. ${ }^{87}$

Finally, permitted pressure tactics can become impermissible if they're carried too far. Isolation, extended interrogation, uncomfortable conditions of confinement and prolonged aggressive questioning by multiple interrogators, are all common practices that are widely used and tolerated. But if they're sufficiently severe, and if a court is so disposed, they may contribute to a finding that a confession was involuntary under the totality of the circumstances. ${ }^{88}$

So far we have not mentioned Miranda $v$. Arizona ${ }^{89}$ easily the best known Supreme Court case on interrogations. Miranda, as it was originally decided, provided that a suspect in police custody may not be questioned unless she has been informed that she has the right to remain silent, to talk to a lawyer (free if necessary), and to have that lawyer present at the questioning; and unless she then voluntarily waived those rights. Since Miranda was decided, most litigation on confessions has focused on its requirements.

Over the past 20 years, however, Miranda has been severely limited by several Supreme Court cases. Among other developments, the Court has held that statements obtained in violation of Miranda may be used against other criminal defendants-and to rebut the defendants who made them if they testify at trial; and that officers may not be sued for damages for violating Miranda. ${ }^{90}$

In light of these cases, the best interpretation of current Supreme Court law is that a Miranda violation is not in itself "misconduct" that may produce an "involuntary" confession, but rather an event that creates a limited opportunity for a defendant to prevent the state from using some statements by that defendant in its case in chief at a trial of that defendant. Accordingly, we do not classify violations of Miranda as official misconduct.

\section{COERCIVE MISCONDUCT IN INTERROGATIONS THAT PRODUCE FALSE CONFESSIONS}

Most false confessions in convictions that ended in exoneration were obtained by coercive misconduct in interrogations, $57 \%$ overall. As with the frequency of false confessions themselves, Chicago leads the pack in the rate of misconduct among false confessions, $77 \%$ compared to $49 \%$ elsewhere. It appears that Chicago has a uniquely high rate of false confessions in large part because of the prevalence of misconduct that produces most of those false confessions. See Table 13:

86 See, e.g., Commonwealth v. Mandile, 397 Mass. 410, 414 (1986).

${ }^{87}$ Frazier v. Cupp, 394 U.S. 731,739 (1969). See also Laurie Magid, "Deceptive Police Interrogation Practices: How Far Is Too Far?" 99 Mich. L. Rev. 1168, 1169 (2001).

88 See, e.g., Davis v. North Carolina, 384 U.S. 737, 752-53 (1966); Ashcraft v. Tennessee, 322 U.S. 143, 153-55 (1944).

${ }^{89}$ Miranda v. Arizona, 384 U.S. 436, 467-473 (1966).

${ }^{90}$ Chavez v. Martinez, 538 U.S. 760 (2003). 
Table 13: Proportions of Exonerations with False Confessions after Coercive Misconduct in Interrogations, in Chicago and Elsewhere*

\section{Exonerations \\ in Chicago}

(75)

\begin{tabular}{|c|c|c|c|c|}
\hline \multirow{3}{*}{ 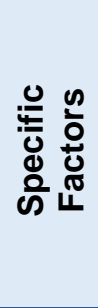 } & $\begin{array}{l}\text { Actual or Threatened } \\
\text { Violence }\end{array}$ & $69 \%(52 / 75)$ & $24 \%(53 / 217)$ & $36 \%(105 / 292)$ \\
\hline & $\begin{array}{l}\text { Sham Plea Bargaining and } \\
\text { other Lies about the Law }\end{array}$ & $23 \%(17 / 75)$ & $18 \%(40 / 217)$ & $20 \%(57 / 292)$ \\
\hline & $\begin{array}{l}\text { Threats to Relatives } \\
\text { and other Third Parties }\end{array}$ & $7 \%(5 / 75)$ & $8 \%(18 / 217)$ & $8 \%(23 / 292)$ \\
\hline \multicolumn{2}{|c|}{$\begin{array}{l}\text { Coercion Found by a Court, } \\
\text { Without Specific Factors }\end{array}$} & $3 \%(2 / 75)$ & $3 \%(6 / 217)$ & $3 \%(8 / 292)$ \\
\hline \multicolumn{2}{|c|}{$\begin{array}{l}\text { Other Cases with Coercive } \\
\text { Misconduct in Interrogations }\end{array}$} & $3 \%(2 / 75)$ & $6 \%(14 / 217)$ & $5 \%(16 / 292)$ \\
\hline \multicolumn{2}{|c|}{$\begin{array}{l}\text { ALL CASES WITH MISCONDUCT } \\
\text { IN INTERROGATIONS }\end{array}$} & $77 \%(58 / 75)$ & $49 \%(107 / 217)$ & $57 \%(165 / 292)$ \\
\hline
\end{tabular}

* Some cases include more than one type of misconduct.

In the great majority of cases with misconduct that produced false confessions $-87 \%$ (143/165) - that misconduct included one or more of the three specific categories we've discussed: violence, sham plea bargaining and other lies about the law, and threats to third parties. In the remaining cases, the misconduct was more variable, but typically consisted of aggravated forms of prolonged questioning, isolation, sleep deprivation, and other practices that are tolerated in milder doses.

\section{a. Violence}

Physical violence, or the threat of imminent violence, is the most common type of misconduct in interrogations that produce false confessions. It was used in $64 \%$ of interrogations with misconduct (105/165). The actual conduct involved varied greatly. Sheriff's deputies in Lake County, Illinois, for example, threatened to "beat the [expletive] out of" Jason Strong, while police officers in Philadelphia chained Edward Baker to a chair and actually beat him with sticks and a telephone book for hours. Both are criminal acts-assault in one case, battery in the other-and both are subject to criminal, civil, and professional sanctions.

\section{i. Torture in Chicago}

Threatened or actual violence contributed to more than a third of false confessions in the Registry. See Table 13. Here again, Chicago is in a class of its own. Sixty-nine percent of false confessions in exonerations in Chicago were obtained by violence or threats of violence, nearly 
three times the rate for the rest of the country. Half of all known cases of violence in obtaining false confessions from exonerated defendants in the country occurred in Chicago (52/105).

Some other large cities have elevated rates of violence in interrogations, but they lag far behind. New York City is a telling comparison.

New York City has a much larger population than Chicago, 8.6 million compared to 2.7 million, but about $25 \%$ fewer exonerations, 173 vs. 230. Only 13\% of exonerations in New York City included false confessions (22/173)-about the same rate as the country as a whole-compared to $33 \%$ in Chicago. And while the rate of violence in the interrogations that led to those false confessions is comparatively high in New York City-41\% (9/22), nearly double the rate for the rest of the country, excluding Chicago and New York City (44/195)-it's much lower than the rate of violence in exonerations with false confessions in Chicago, 69\%. The net result is that Chicago, with one-third the population of New York City, has almost six times as many exonerations with false confessions that were extracted by violence, 52 compared to 9 .

A major part of the reason for Chicago's unique status is that from the early 1970s through the 1980 s hundreds of suspects-almost all Black men-were tortured by a group of Chicago police detectives under the command of Lieutenant (later Commander) Jon Burge. (We discuss the Burge torture regime and its causes in greater detail below. ${ }^{11}$ )

In 1986, a couple was stabbed and killed in their apartment on the south side of Chicago. A few days later, a 15-year-old girl told police that Aaron Patterson admitted to committing the murder, and a neighbor said he had seen Eric Caine in the vicinity. Patterson and Caine were arrested and taken for interrogation to the Area 2 police station, under the command of Lieutenant Jon Burge.

Caine, the son of a Chicago police officer, was told that Patterson had confessed that he and Caine went to the house to find weapons and ended up killing the couple. After Caine refused to confess, Detectives beat him and took him to see Patterson, who had been beaten so badly he could barely speak. Caine signed a confession.

Patterson, left alone in the interrogation room with a confession to sign, used a paperclip to scratch a message on a metal bench: "Police threaten me with violence. Slapped and suffocated me with plastic. No lawyer or dad. Sign false statement to murders.”

Patterson and Caine were convicted of murder in 1989. Patterson was sentenced to death; he received a pardon based on innocence in 2003. Caine was sentenced to life in prison, and exonerated in 2011.

${ }^{91}$ See infra, Section XII.1.b. 
Caine and Patterson were exonerated because of litigation by other torture victims. In 1989, a man name Andrew Wilson sued the city for torture at the hands of Burge and his officers. ${ }^{22}$ That case led to an investigation of Burge and his subordinates by the Chicago Police Department, and a report in 1990 that concluded that "the number of incidents in which an Area 2 command member is identified as an accused [in torturing suspects] can lead to only one conclusion. Particular command members were aware of the systematic abuse and perpetuated it either by actively participating in [the] same or failing to take any action to bring it to an end."93

The Burge torture cases have been in the public eye ever since. In 2009, the State of Illinois created a "torture commission" to review his actions and the cases he oversaw.94 Ultimately, 19 defendants who confessed under torture by Burge and his men were exonerated and are listed in the Registry. 95 If their cases had not been part of a well-established pattern of torture, many would still be in prison.

No eyewitness or physical evidence placed Caine at the scene of the crime. Without Caine's confession (and Patterson's) there was no evidence against him, but such is the power of a confession-"the queen of evidence" 96 - that nothing else was needed. The trial pitted Caine-a terrified Black teenager, trying to avoid prison if not execution by convincing the jury that he was tortured-against experienced white police officers who testified that he confessed voluntarily. Naturally, Caine lost.

After conviction, Caine faced the added burden of convincing a court to reject the jury's findings. Paradoxically, the absence of corroborating evidence made that task harder. There were no eyewitnesses to recant, no biological evidence to test, and no witness bias to uncover. All he could do was try, once again, to pit his credibility against that of the police.

Of the 53 exonerees outside of Chicago who falsely confessed due to violence or threats of violence, only three were exonerated solely by evidence that their confessions were coerced. 97 The other 50 all relied on other types of evidence that did not exist in Caine's case: DNA tests, witness recantations, alibi witnesses, non-DNA forensic evidence, or information pointing to the real criminal.

92 Chicago Tribune staff, Jon Burge and Chicago's legacy of police torture, Chicago Tribune (Sept. 19, 2018).

93 Chi. Police Dep't Office of Prof'l Standards, Special Report (1990).

94 TIRC Home: Mission and Procedures Statement, St. of III. Torture Inquiry and Relief Commission).

95 The 19 exonerees in the first 2,400 exonerations who confessed after torture by Burge and his subordinated are: James Andrews, Kevin Bailey, Corey Batchelor, David Bates, Eric Caine, Arnold Day, David Fauntleroy, Madison

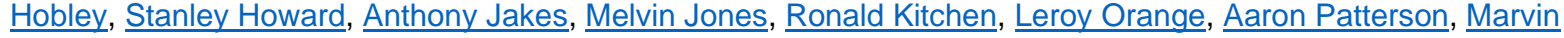
Reeves, Alonzo Smith, Michael Tillman, Shawn Whirl, and Stanley Wrice. Since we completed the 2,400 exoneree dataset for this report, we have added five additional exonerations of defendants who gave false confessions after abuse by Jon Burge and his subordinates, for a current total of 24: Gregory Banks, James Gibson, Victor Safforld, Demond Westin, and Keith Walker.

96 In Latin: confessio est regina probationum. See Peter Brooks, Troubling Confessions: Speaking Guilt in Law and Literature, University of Chicago Press (2000) at p. 93.

97 Robert Coney, William Oakes, James Simmons. 
In Chicago, however, after courts found that dozens of other men had been tortured by Burge and his men, Caine's words did not stand alone. That's why he was freed after 22 years in prison. We have no idea how many Eric Caines in other cities have never been identified because officers who abused them did not do it as part of a concerted pattern of torture that, eventually, could not be ignored.

(To be clear, torture in Chicago was not a one-man show. Thirty-three of the 52 Chicago exonerations with false confession extracted by violence did not involve Jon Burge in any capacity; in 13, the interrogations happened after he retired.)

ii. Violence in interrogations of suspects with mental disabilities

It's well known that people with mental illness or diminished intellectual capacity are far more likely than others to confess falsely. ${ }^{9}$ We see that in these cases. Seventy percent of exonerees with mental disabilities falsely confessed (103/147)-including 81\% of mentally-disabled murder exonerees (77/95) - compared to $8 \%$ of exonerees without such disabilities $(189 / 2,253)$.

Mentally-disabled exonerees who falsely confessed were less likely than others to be victims of violence in interrogation, 27\% (28/103) compared to 41\% (77/189)-and half of the mentallychallenged exonerees who confessed after some use of violence by police experienced comparatively mild versions: slapping, grabbing, or threatening. None was subjected to the sort of torture that was regularly used by Jon Burge and his crew.

The likely explanation is that it's easier to get a confession without resorting to violence if the suspect has a mental disability. Manipulation and lesser forms of coercion usually do the trick, and if violence is used, relatively mild forms are generally enough.

\section{b. Sham Plea Bargaining and other lies about the law}

Detective Willoughby lied when he offered Bobby Johnson probation in exchange for a confession. He had no power to make that deal and could not enforce it if he tried. Willoughby also told Johnson he'd be sentenced to the death penalty if he did not confess. That too was a lie. By 2005, the death penalty could not constitutionally be imposed on a defendant as young as Johnson.

Deception about the law-unlike deception about the facts of the case at hand-is misconduct. Police officers are seen by civilians as authorities on the law; suspects are likely to believe police lies about the law because they have no independent knowledge of their own-and that can make a resulting confession "involuntary" and inadmissible in court. Judging from exonerations, the most common form of deception about the law in interrogations is sham plea bargaining by police.

98 See Steven A. Drizin \& Richard A. Leo, The Problem of False Confessions in a Post-DNA World, 82 N.C. L. Rev. 891, 970-71 (2004); Nat'l Registry of Exonerations, Age and Mental Status of Exonerated Defendants Who Confessed. 
The power to decide whether to prosecute, and on what charges, rests entirely with prosecutors. If a suspect confesses because the prosecutor offered in return to reduce the charge from murder to manslaughter, that creates an enforceable deal. Plea offers by prosecutors can put extreme pressure on suspects to confess, truthfully or not. Kenneth Kagonyera, for example, was facing the death penalty in North Carolina when he confessed to a murder he had no part in, and pled guilty, in return for a sentence of 12 to 15 years. That sort of pressure is legal, accepted and a central element of our system of criminal procedure. 99

Since he had no authority to strike a deal with Johnson, Detective Willoughby's offer of probation in return for a confession amounted to a lie about criminal procedure. In $18 \%$ of the false confession cases in the Registry, an officer purported to offer a plea arrangement to a suspect in return for a confession (54/292). These unauthorized and unenforceable offers included probation, diversion from criminal prosecution, lenient sentencing, reduced charges, and psychiatric treatment in lieu of prison.

In about half of those cases, officers threatened the suspects with the death penalty if they did not confess (25/54). The police, of course, had no authority to make good on the implied or explicit promise that the exoneree would be spared the death penalty if he did confess; Damon Thibodeaux, for example, falsely confessed after he was threatened with the death penalty in Louisiana if he refused to do so; he was sentenced to death anyway.

\section{c. Threats to Third Parties}

On March 8, 1987, Richard Lapointe and his wife, Karen, went to the house of Karen's grandmother, Bernice Martin, in Manchester, Connecticut, and visited with her for a few hours. They left at 4 p.m. At 8 p.m. they received a call from Bernice's daughter (Karen's aunt) asking Lapointe to check on Bernice. Twentyseven minutes later, Lapointe called 911 to report a fire at Bernice's house.

Bernice was removed from the house, dead from stab wounds.

The murder investigation stalled for two years until a new detective took over and focused on Lapointe. During questioning, police told Lapointe that his wife had implicated him in the murder-and said they would arrest her and take his son away if he did not confess.

After nine hours of interrogation, Lapointe (who suffered from a congenital neurological disease) signed a confession that was inconsistent with forensic evidence on many points, and left out other key facts. Lapointe was convicted in 1992, largely based on his confession. He was exonerated in 2015 after it was discovered that a fire investigator had concluded that the fire began while Lapointe was still at home, and DNA tests excluded him as the source of the biological evidence found at the crime scene.

\footnotetext{
99 See Brady v. United States, 397 U.S. 742 (1970); Bordenkircher v. Hayes, 434 U.S. 357, $362-64$ (1978); Missouri v. Frye, 566 U.S. 134, 144 (2012) (" [P]lea bargaining ... . is not some adjunct to the criminal justice system; it is the criminal justice system."); Lafler v. Cooper, 566 U.S. 156 (2012).
} 
The threat to arrest Lapointe's wife and take his son into state custody was credible. The police may have had enough evidence to arrest Karen, and if they did, they would have called child protective services to take their son. In fact, they never arrested her and probably never intended to. Their goal was to get Lapointe to confess, and it worked. For that purpose, the threat was misconduct.

Police are allowed to tell a suspect that if he doesn't talk they will arrest him, assuming they have probable cause to do so. Apparently, courts believe that suspects will not confess to crimes they did not commit simply to avoid arrest. But similar threats against a suspect's spouse or child change the equation. They are thought to be intrinsically unfair and more likely to lead to false confessions by suspects who are anxious to protect those they love.

In 23 cases in the Registry-8\% of exonerations with false confessions-the exoneree falsely confessed after an officer threatened to arrest a member of the exoneree's family, place one or more children in the exoneree's family in state custody, or otherwise put family members in harm's way if the exoneree did not confess. See Table 13.

\section{PERMITTED INTERROGATION PRACTICES THAT LEAD TO FALSE CONFESSIONS}

Frank Sterling, as we saw, confessed to a murder he did not commit after police lied about evidence against him and convinced him he had no real choice but to confess. There was no misconduct in that interrogation. Lying about the facts of a crime or the evidence the police have obtained is not misconduct, and may be effective at securing true confessions-but, as we also noted, it increases the risk of false confessions. ${ }^{100}$

Several interrogation tactics fit this description: police are allowed to use them to maneuver reluctant suspects to confess, and they do it because it works-but in the process, they generate false confessions from innocent suspects. This applies to the overall structure of many American murder interrogations: prolonged aggressive questioning of a suspect who is uncomfortable, tired, and isolated from all other contacts. As we've mentioned, that practice is permitted by the courts, except in rare cases in which they say it went too far.

We don't have sufficiently detailed data to detect and describe many of the features of the interrogations that produced false confessions. But we are able to identify a few practices of this sort: lying about the investigation; making promises and threats that are not categorically prohibited; feeding details of the crime to the suspect; and interrogating a juvenile with no parent present.

\section{a. Lying about the investigation}

Lying about the law in interrogations is prohibited, as we've mentioned, perhaps because suspects are likely to regard police as experts on the law and will therefore be easily misled. Lying about evidence is another matter; it's routinely permitted. ${ }^{101}$ Courts seem to believe that

\footnotetext{
100 Supra Section V.1.a.

101 See, e.g., Frazier v. Cupp, 394 U.S. 731, 739 (1969).
} 
while suspects who are guilty may be tricked into confessing by false claims that their guilt is already proven, those who know they are innocent will not be shaken by lies about witnesses or physical evidence. That is not always true in practice.

In 2004, police in Maricopa County, Arizona, questioned 20-year-old John Watkins because he resembled a woman's description of the stranger who raped her. They told Watkins that they had recovered his fingerprints from the scene, and that the victim had identified him. Watkins agreed to take a voice-stress analysis test and was told that he failed. In the face of this "evidence," Watkins confessed. It was all lies. There were no fingerprints and no identification by the victim, and he had not failed the voice test. In 2004, Watkins pled guilty to rape; in 2010, he was exonerated by DNA evidence that proved he was not the rapist.

Watkins, like Frank Sterling, confessed because police officers convinced him (falsely) that they had him dead to rights without a confession. Police get a lot of convictions that way-including in $23 \%$ of cases in which innocent suspects confessed, were convicted, and were later exonerated. Often, as in the Watkins' case, they lie about physical evidence that supposedly linked the exoneree to the crime. In four cases, police gave suspects real or fake polygraph tests, and then falsely told them they had failed.

Another common deceptive tactic is to claim that an eyewitness identified the suspect, or that an alibi witness failed to support their defense. John Horton, for example, told police he was with his brother at the time of the murder they were investigating. He falsely confessed (and was wrongly convicted) after police lied and said that his brother had repeatedly denied seeing him on the night of the murder.

\section{b. Permissible promises and threats}

As we've discussed, some types of promises are off limits in interrogations. In particular, police are forbidden to promise specific legal outcomes if the suspect confesses-dismissal of charges, probation, whatever-because they don't have the legal authority to make good on such promises. Police are also forbidden to make some threats, especially threats of violence and threats to take action against children, spouses, and other third parties who are dear to the suspect.

But there are many types of promises and threats that police are allowed to make in interrogations, whether or not they ever intend to keep them. Vague promises or threats are generally fine, even though a terrified young suspect that might not notice the difference between "Things will get very tough if you don't tell us what happened, right now" (permitted) and "You'll be charged with aggravated murder unless you tell us what happened, right now" (prohibited).

The basic test is this: Are the police promising or threatening to do things that they have the power to do? If so, it's OK. Police may make recommendations to prosecutors and judges, so they may promise (or imply) that they will do so, even if they have no such intention. They may also threaten to arrest a suspect, or promise to refrain from making an arrest-both are within their power. Probably their most common promise is to allow suspects to go home if they 
confess. Indeed, some exonerees-including Bobby Johnson-were allowed to go home after they confessed. They just didn't get to stay there.

Some promises were more specific:

In March 1997, 16-year-old Fancy Figueroa was raped by a stranger after she got home from school in Queens, New York. She was taken to a hospital for a rape kit, but when it was discovered she was pregnant, police concluded that she lied about the rape to cover up the real cause of her pregnancy. They told her that if she wrote down on a piece of paper that she was lying, they would help her look for the rapist. She complied, and was charged with and convicted of filing a false police report. The officers didn't follow up on the rape-they considered the matter closed by Figueroa's admission that she'd lied. She was exonerated seven years later when the DNA from her rape kit was matched to a serial rapist in a routine search of a DNA database.

The officers' promise to investigate Figueroa's report if she admitted it was false made no sense, and they had no intention of keeping it-but it was a permissible promise. Some permissible promise or threat, or a combination, contributed to $18 \%$ of false confessions in exonerations.

\section{c. Feeding the suspect details of the crime}

In 1993, the United States Court of Appeals for the Fourth Circuit reviewed Earl Washington's 1984 rape-murder conviction in Virginia, and concluded that Washington's confession proved his guilt beyond doubt:

"Washington had supplied without prompting details of the crime that were corroborated by evidence taken from the scene. ... He had confessed to the crime... as one who was familiar with the minutiae of its execution."102

In other words, his confession was persuasive because he volunteered facts that only the criminal could know. But Washington was innocent. He was exonerated in 2000 after two sets of DNA tests proved he was not the rapist who killed the victim.

How did Washington know facts "that only the criminal could know"? He learned them from the only other people who know such facts: the officers who investigated the case. Washington had a learning disability; his IQ was 69. He handled his disability by politely agreeing with people in authority, such as police officers. When asked whether he committed the crime, he confessed, but in the first version of his confession he didn't know the race of the victim, her address, or that she had been raped. Eventually, with a great deal of help, he managed to produce a confession that was coherent enough for the police to use-and not too inconsistent with known facts.

102 Washington v. Murray, 4 F.3d 1285, 1292 (4th Cir. 1993). 
Washington's case is hardly unique. Professor Brandon Garrett studied 40 DNA exonerations in which the defendants falsely confessed. He reports:

"Thirty-six of the thirty-eight cases for which transcripts were obtained had confessions that reportedly included specific details about how the crime occurred. ... At trial, law enforcement testified that the suspect had volunteered specific details about how the crime occurred, typically details corroborated by expert evidence or crime scene evidence. ... Almost all exonerees were reported to have provided detailed statements that included facts likely to be known only by the culprit."103

It is not misconduct for police to tell a suspect the details of a crime. The most common way they do it is to ask leading questions ("You stabbed her with the butcher knife, didn't you?")—which was certainly done in Washington's interrogation. Officers may take the suspect to the scene of the crime, which was also done with Earl Washington, after he himself was unable to locate the apartment where the crime occurred. In other cases-for example, in Frank Sterling's murder interrogation-police show the suspect pictures of the crime scene or the victim. In some cases, officers divulge critical facts without realizing it. Former District of Columbia police detective James Trainum, for example, has described a case in which he did so inadvertently by showing the suspect photographs that contained information he didn't notice, and asking leading questions he forgot. ${ }^{104}$

Hearing a detailed description of a violent crime-or seeing pictures, or being taken to the scene-can be very troubling. It puts pressure on the suspect to confess and end the ordeal; that's one reason it's done. Like other pressure tactics, it can contribute to confessions from innocent defendants, and it can make those confessions seem more credible than they are. "Telling details" in a confession make it believable and powerful if the suspect knew those details. If they were supplied by the police, knowingly or unawares, they may convince a court that an innocent person is guilty.

The simple cure for feeding details to the suspect is to studiously avoid doing it-but that can be difficult, especially since it can happen unintentionally. Not surprisingly, feeding details of the crime to the suspect is very common; it occurred in $56 \%$ of false confessions by exonerated defendants. The next best solution-and the one more likely to work-is to make video recordings of interrogations so investigators, lawyers and courts can tell whether details of the crime were supplied by the police. Detective Trainum, for example, was only able to figure out how he inadvertently passed such information to an innocent suspect by carefully reviewing a video of the interrogation. Recording interrogations in full has become more common in recent

103 Brandon L. Garrett, The Substance of False Confessions, 62 Stan. L. Rev. 1051, 1066 (2010). See also Brandon Garrett, Judging Innocence, 108 Columbia L. Rev. 55, 89 (2008).

104 James Trainum and Diana Havlin, "A False Confession to Murder in Washington, DC," in Criminal Investigative Failures, ed. D. Kim Rossmo (Boca Raton, Florida: CRC Press, 2009), 205-217. 
years, ${ }^{105}$ but was only done in eight interrogations that led to false confessions by defendants who were later exonerated.

\section{d. Interrogating a juvenile with no parent present}

Juveniles, like suspects with mental disabilities, are prone to false confessions. Thirty-six percent of exonerees who were under 18 at the time of the crime with which they were charged falsely confessed, compared to $10 \%$ of exonerees who were 18 or older.

Most states have rules that specify whether and when a parent or guardian must be present at the interrogation of a juvenile suspect, but those rules vary widely. Some states require parents to be present if the child requests it; ${ }^{106}$ others require the police to notify a parent who can waive the right to be present. ${ }^{107}$ Some states require parental presence for any child under $18 ;{ }^{108}$ some only require it for those under $16 .{ }^{109}$ The Supreme Court has not spoken on the issue.

Given the wide range of rules on parental presence, we cannot say that interrogating a minor without a parent is misconduct-but it certainly appears to be dangerous. We know that almost two-thirds of exonerees who falsely confessed as juveniles did so without a parent present (48/76); there may be others where that fact was not mentioned in the records we could obtain. Part of the reason may be that police committed misconduct in $67 \%$ of interrogations of juveniles without parents, but only $46 \%$ of such interrogations with a parent present.

\section{e. General patterns}

In Table 14 we display the rates of the permitted interrogation practices we discussed among exonerations with and without misconduct in interrogations. Each of these permitted practices that contribute to false confessions was more common in interrogations with misconduct than in those without misconduct. Overall, $79 \%$ of interrogations with misconduct included at least one of these dangerous practices, compared to $57 \%$ of interrogations without misconduct. ${ }^{110}$

105 See infra Section XII.2.b.ii(a).

106 See, e.g., Ala. Code $§ 12-15-202$ (2008).

107 See, e.g., Me. Rev. Stat. Ann. tit. 15, § 3203-A (2011).

108 See, e.g., Colorado Revised Statutes Title 19. Children's Code § 19-2-511.

109 See, e.g., North Carolina General Statutes Chapter 7B. Juvenile Code § 7B-2101.

110 The contrast become slightly sharper if we focus on interrogations with violence, the most severe form of misconduct: $81 \%$ of interrogations with violence or threats of violence included one or more of these tactics (85/105), compared to $64 \%$ of interrogations with no suggestion of violence $(119 / 186)$. 
Table 14: Proportions of Exonerations with Permitted Interrogation Practices that Contribute to False Confessions, With and Without Misconduct in Interrogation*

\begin{tabular}{|c|c|c|c|}
\hline & $\begin{array}{l}\text { False Confessions } \\
\text { With Misconduct } \\
\text { In Interrogation }\end{array}$ & $\begin{array}{l}\text { False Confessions } \\
\text { Without Misconduct } \\
\text { In Interrogation }\end{array}$ & $\begin{array}{c}\text { ALL } \\
\text { EXONERATIONS } \\
\text { WITH FALSE } \\
\text { CONFESSIONS }\end{array}$ \\
\hline $\begin{array}{l}\text { Lying about the } \\
\text { Investigation }\end{array}$ & $\begin{array}{l}24 \% \\
(40 / 165)\end{array}$ & $\begin{array}{l}21 \% \\
(27 / 127)\end{array}$ & $\begin{array}{l}23 \% \\
(67 / 292)\end{array}$ \\
\hline $\begin{array}{l}\text { Permissible Promises } \\
\text { and Threats }\end{array}$ & $\begin{array}{c}20 \% \\
(33 / 165)\end{array}$ & $\begin{array}{c}16 \% \\
(20 / 127)\end{array}$ & $\begin{array}{l}18 \% \\
(53 / 292)\end{array}$ \\
\hline $\begin{array}{l}\text { Feeding the Suspect } \\
\text { Details of Crime }\end{array}$ & $\begin{array}{c}69 \% \\
(114 / 165)\end{array}$ & $\begin{array}{l}39 \% \\
(49 / 127)\end{array}$ & $\begin{array}{c}56 \% \\
(163 / 292)\end{array}$ \\
\hline $\begin{array}{l}\text { Interrogating a Juvenile } \\
\text { With No Parent Present }\end{array}$ & $\begin{array}{c}19 \% \\
(32 / 165)\end{array}$ & $\begin{array}{c}13 \% \\
(16 / 127)\end{array}$ & $\begin{array}{c}16 \% \\
(48 / 292)\end{array}$ \\
\hline $\begin{array}{l}\text { AT LEAST ONE IDENTIFIED } \\
\text { CONTRIBUTING PRACTICE }\end{array}$ & $\begin{array}{c}79 \% \\
(131 / 165)\end{array}$ & $\begin{array}{c}57 \% \\
(73 / 127)\end{array}$ & $\begin{array}{c}70 \% \\
(204 / 292)\end{array}$ \\
\hline
\end{tabular}

* Some cases include more than one type of contributing practice.

Violence in interrogations is in a category of its own, but the other tactics we discussed, permitted and prohibited alike, all aim to exhaust, trick, scare and manipulate suspects into confessing - without physical abuse. It's no surprise that interrogators who work close to the line often step over it, and that those who break the rules also make aggressive use of legitimate moves. Misconduct and permitted interrogation practices differ from each other in degree, not in kind.

With the possible exception of interrogating a juvenile without a parent, all these practicestorture, threats to third parties, lying about the investigation, feeding details to the suspect, and so forth-undercut the power of any resulting confession, if they are observed. They are much less likely to happen if interrogations are recorded, and if they do occur they can be considered by juries in evaluating the resulting confessions, and by judges in deciding on their admissibility. There's a hint of the possible impact in our data. Five of the eight confessions that were obtained in interrogations that were recorded in their entirety-63\%-were ruled inadmissible in evidence by judges who saw or heard the recordings.

\section{MISCONDUCT IN THE INTERROGATION OF CODEFENDANTS}

Confessions by the defendants are not the only false confessions that contribute to the conviction of innocent people. In 13\% of exonerations, suspects who were, or might have been charged as codefendants gave confessions that implicated the exonerees as well as themselves. In fact, codefendant confessions that implicated exonerees were slightly more common than false confessions by the exonerees themselves, 315 to 292. 
In some cases, the confessing codefendants avoided charges altogether. Randall Dale Adams, for example, was sentenced to death in 1977 for killing a police officer because David Harris, the actual killer, testified that Adams-a hitchhiker who had been in his car earlier in the day-shot the officer from Harris's car with Harris's gun. Based on his testimony, Harris could easily have been charged as an accomplice or an accessory to murder. Instead, he became the star witness at Adams's trial, got off scot-free, and went on to commit another murder for which he was executed 27 years later. ${ }^{111}$

Other confessing codefendants did not fare as well. In Austin, Texas, for example, police threatened Christopher Ochoa with execution if he did not confess, and with rape in prison, and with beating by the officers themselves. In 1989, Ochoa confessed, pled guilty to murder and went on to testify at the trial of his codefendant, Richard Danziger, that they raped and murdered the victim together. He avoided the death penalty, as promised, but he, like Danziger, was sentenced to life in prison. Both were exonerated by DNA in 2002.

A third of exonerations with codefendant confessions also include false confessions by the exonerees (107/315), and two-thirds do not. The net effect is that false confessions-counting those by codefendants as well as by exonerees themselves-contributed to the convictions of $21 \%$ of all exonerees (500/2400).

Nearly three-quarters of exonerations with incriminating codefendant confessions were murder cases (233/315), and a disproportionate number occurred in Chicago, where a slight majority of all murder exonerations included codefendant confessions. See Table 15. These patterns, of course, are familiar; we saw almost exactly the same thing in Table 12, for false confessions by exonerees.

Table 15: Proportion of Exonerations with Confessions by Codefendants, in Chicago and Elsewhere

\begin{tabular}{lcc|c} 
& $\begin{array}{c}\text { Exonerations } \\
\text { in Chicago }\end{array}$ & $\begin{array}{c}\text { Exonerations } \\
\text { Elsewhere }\end{array}$ & \multicolumn{1}{c}{$\begin{array}{c}\text { ALL } \\
\text { JURISDICTIONS }\end{array}$} \\
\hline Murder & $\begin{array}{c}51 \% \\
(60 / 118)\end{array}$ & $\begin{array}{c}22 \% \\
(173 / 790)\end{array}$ & $\begin{array}{c}26 \% \\
(233 / 908)\end{array}$ \\
\hline All other Crimes & $\begin{array}{c}3 \% \\
(3 / 112)\end{array}$ & $\begin{array}{c}6 \% \\
(79 / 1380)\end{array}$ & $\begin{array}{c}5 \% \\
(82 / 1492)\end{array}$ \\
\hline ALL CASES & $\begin{array}{c}27 \% \\
(63 / 230)\end{array}$ & $\begin{array}{c}12 \% \\
(252 / 2,170)\end{array}$ & $\begin{array}{c}13 \% \\
(315 / 2,400)\end{array}$ \\
\hline
\end{tabular}

Codefendants who confess are usually suspects themselves. That means that police are permitted to interrogate them using the aggressive and frequently coercive techniques that are

111 See supra Section IV.2. 
permitted in interrogations of all suspects, including lying about physical evidence and statements by witnesses, and making some types of threats and promises. That sort of questioning might be misconduct-witness tampering-if applied to ordinary witnesses, but not when used in the interrogation of suspects. We only count the process of obtaining codefendant confessions as misconduct if it includes actions that we would count as misconduct in interrogations of the exonerees themselves, as suspects.

Most codefendant confessions that were used to convict exonerees were obtained without misconduct. There was no misconduct, for example, in the interrogation of David Harris. Once he was told that ballistic evidence confirmed that the victim was shot with his gun, he jumped at the chance to shift the blame to Adams-and managed to get away with murder, literally. That impulse is common, if not always as successful. Many confessing codefendants were guilty of the crimes they confessed to, and falsely implicated others to avoid conviction or minimize the punishment.

On the other hand, it took extreme misconduct to persuade Ralph Myers to confess that he drove Walter McMillian to the scene of a robbery murder in Monroeville, Alabama, heard shots, and saw McMillian standing over and robbing the body of the dead victim. Myers, a career criminal, was suspected of a murder in a nearby county. But instead of pursuing that case, the police told Myers that they had witnesses who would get him convicted and executed for the Monroeville murder-unless he implicated McMillian in that crime. McMillian was sentenced to death; Myers pled guilty and got 30 years. Five years later, defense attorneys stumbled on a hidden tape recording in which Myers complained bitterly that he was being forced to implicate McMillian-whom he had never met-and to confess to participating in a crime that neither of them had any role in.

Thirty-five percent of codefendant confessions in exonerations were obtained by official misconduct (110/315), $5 \%$ of all exonerations $(110 / 2,400)$.

In $44 \%$ of exonerations with codefendant confessions that were obtained by misconduct, the exonerees themselves also falsely confessed (48/110). For example, in 1993, Daniel Villegas, a 16-year-old with learning disabilities, confessed to a double drive-by murder in El Paso, Texas after an interrogation in which he was handcuffed to a chair for hours and threatened with violence. In addition, two other teenagers confessed after their own abusive interrogations, and implicated Villegas; they were both charged with murder but charges were later dismissed. Villegas was convicted in 1995 and sentenced to life in prison, based on his own confession as well as those of the other two suspects. (Yet another youth had falsely confessed earlier to the same crime, after a similar interrogation, but was never charged.) Villegas was exonerated in 2018, after the nature of the interrogations in the case was exposed, and the likely real criminals were identified.

As with all codefendant confessions in exonerations, those obtained by misconduct were concentrated among murder cases, which make up three-quarters of the total (83/110), and in Chicago. More than a quarter of all murder exonerations in Chicago included codefendant confessions obtained by misconduct (31/118). See Table 16. 
Table 16: Proportion of Exonerations with Codefendant Confessions Obtained by Misconduct, in Chicago and Elsewhere

\begin{tabular}{|lcc|c} 
& $\begin{array}{c}\text { Exonerations } \\
\text { in Chicago }\end{array}$ & $\begin{array}{c}\text { Exonerations } \\
\text { Elsewhere }\end{array}$ & $\begin{array}{c}\text { ALL } \\
\text { JURISDICTIONS }\end{array}$ \\
\hline Murder & $\begin{array}{c}26 \% \\
(31 / 118)\end{array}$ & $\begin{array}{c}7 \% \\
(52 / 790)\end{array}$ & $\begin{array}{c}9 \% \\
(83 / 908)\end{array}$ \\
\hline All other Crimes & $\begin{array}{c}1 \% \\
(1 / 112)\end{array}$ & $\begin{array}{c}2 \% \\
(26 / 1,380))\end{array}$ & $\begin{array}{c}2 \% \\
(27 / 1,492)\end{array}$ \\
\hline ALL CASES & $\begin{array}{c}14 \% \\
(32 / 230)\end{array}$ & $\begin{array}{c}4 \% \\
(78 / 2,170)\end{array}$ & $\begin{array}{c}5 \% \\
(110 / 2,400)\end{array}$ \\
\hline
\end{tabular}

Three-quarters of cases with coerced codefendants confessions were multi-defendant exonerations (82/110). The prototypical exoneration with a codefendant confession that was obtained by official misconduct is a multi-defendant murder exoneration in which the codefendant was convicted along with the exonerees they falsely implicated. The Ford Heights Four exonerations are a good example:

In May 1978, a young white couple were abducted in a Chicago suburb. Their bodies were found the following day; both had been shot, and woman had been gang-raped. Acting on a tip, the police arrested four Black men- Verneal Jimerson, Dennis Williams, Kenneth Adams, and Willie Rainge. They also questioned Paula Gray, a 17-year-old with a mild intellectual disability.

After two days of questioning, Gray told a grand jury that she held a disposable cigarette lighter burning while the four men raped the female victim repeatedly, and that she saw Williams shoot both victims with a .38-caliber pistol. A month later, she recanted her story at a preliminary hearing, and testified that she had been drugged and that the police walked her around the crime scene and told her what to say.

Gray herself was charged with murder and perjury and brought to trial jointly with three of the male defendants-Adams, Rainge, and Williams. All four were convicted; Williams was sentenced to death, Rainge to life, Adams to 75 years and Gray to 50 years.

After Williams and Rainge won new trials in 1982, prosecutors cut a deal with Gray under which she was released in exchange for testifying against Williams and Rainge at their retrial, and against Jimerson, who had not yet been tried. All three were convicted; Williams was again sentenced to death, as was Jimerson, and Rainge to life.

Jimerson, Williams, Adams and Rainge-the Ford Heights Four-were all exonerated in 1996, after DNA evidence proved they had not raped the female victim, the real criminals were identified and confessed, and Gray once more 
recanted her confession and testimony against them. Gray herself was exonerated in 2002 when Illinois Governor George Ryan pardoned her and several other defendants who had falsely confessed in Cook County.

The overwhelming evidence of innocence that exonerated the Ford Heights Four in 1996 also proved Paula Gray's innocence of murder, and made it equally clear that she had committed perjury. And yet she was not exonerated for another six years-perhaps because nobody was motivated enough to help a defendant whose lies, however coerced, led to several false convictions, and who had already been released from prison. Ralph Myers-the codefendant whose false confession put Walter McMillian on death row-fared worse. He served his 30-year sentence and was never exonerated, even though he could not possibly be guilty of helping McMillian commit a crime McMillian had nothing to do with.

In addition to Myers, we know of two other codefendants who falsely confessed and implicated an exoneree, were charged and convicted themselves, and were never exonerated despite clear evidence of innocence. ${ }^{112}$ There may be others; we don't know what happened to many of the confessing codefendants. On the other hand, in 62 exonerations, codefendants like Christopher Ochoa, who implicated the exonerees in a confession obtained by misconduct, were themselves exonerated.

112 Timothy Brown and David Gladden. 


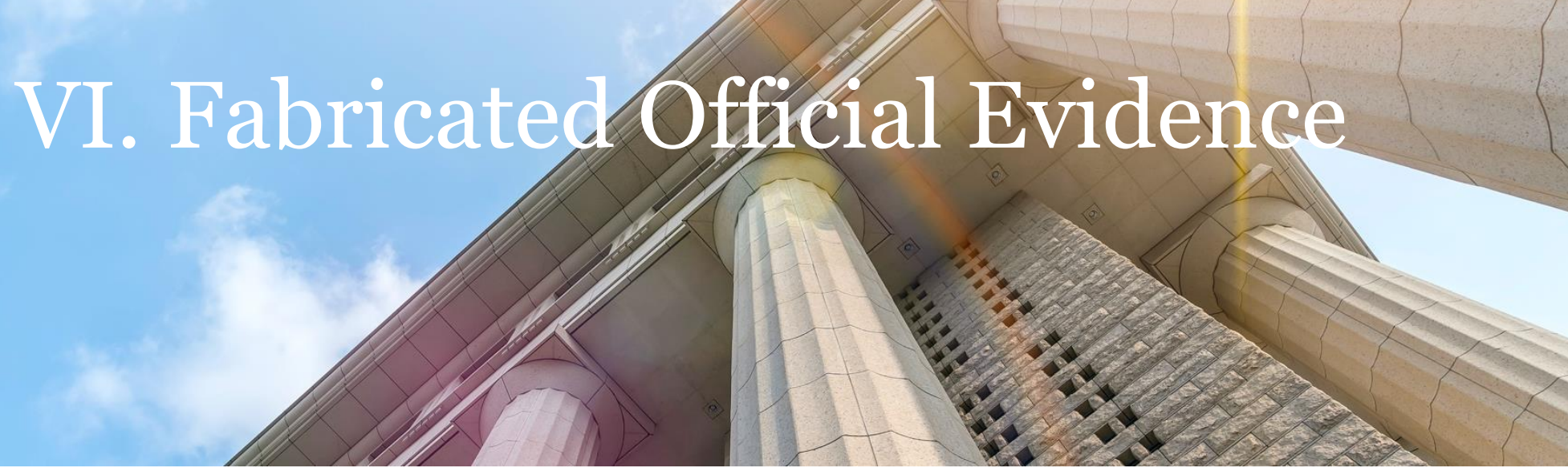

Police and other law enforcement officers are the most important sources of evidence in criminal prosecutions. Usually they write reports or testify about investigations that gathered evidence from other sources, but in a minority of cases they actually witnessed the crimes, or discovered damning evidence against the defendant-or claimed to have done so.

Lies by law enforcement officers contributed to many of the false convictions in the Registry. Often, they lied about the conduct of the investigation-who they talked to, when, what was said and under what circumstances, and so forth. In about 10\% of exonerations, however, police and other officials made up incriminating evidence by lying about their own observations. These cases come in three groups:

- Law enforcement officials-police officers or forensic analysts who work for police agencies-sometimes testify as experts in forensic science and explain the significance of trace evidence and other physical evidence connected to the crime. In about $3 \%$ of exonerations $(75 / 2,400)$, they deliberately presented false evidence against the defendants or concealed or distorted true evidence that might have cleared them.

- In $5 \%$ of exonerations, officers lied as ordinary lay witnesses and said that they saw the defendants commit crimes that never happened-possess illegal drugs or assault the officers who testified, when in fact the drugs were planted and the assaults were made up.

- In about $2 \%$ of exonerations, police made up confessions by the defendants $(36 / 2,400)$.

\section{FORENSIC FRAUD}

"Forensic evidence" is a collection of different types of expert evidence that are used in criminal cases for a variety of purposes: to identify people using biological samples or traces they left behind (DNA, fingerprints, blood type, hair, bitemarks); to identify objects from traces or from marks they left (tool marks, fibers, tire treads, shoe prints); to describe the composition of substances (chemical analyses of drugs or poisons); to describe pathologies (illness, injury, trauma); or to assign causes to events (deaths, injuries, fires).

False or misleading forensic evidence contributed to the false convictions of a quarter of known exonerees $(590 / 2,400)$. In most of those cases, forensic experts did not engage in misconduct 
but rather made mistakes or relied on scientific procedures or beliefs that had been, or later were discredited. In other cases they did commit misconduct, but not fraud; most often, they concealed forensic information that might have helped the defendant.

Forensic fraud, as we use the term, is an aggravated form of intentional misconduct by state actors: the deliberate falsification of forensic evidence by a law enforcement officer in order to help convict a criminal defendant. We do not count fraud by privately employed forensic experts, nor cases in which misstatements about forensic evidence might have been deliberate but we don't know enough to be confident.

We know of forensic fraud in $3 \%$ of exonerations $(75 / 2,400)$. In $83 \%$ of those cases the fraud was committed by a forensic analyst, including two cases in which a prosecutor also participated in the fraud (62/75). In 16\% of the cases, forensic fraud was committed by a police officer (12/75), also including two cases in which a prosecutor participated. And in one case, a prosecutor committed forensic fraud on his own.

Reviewing these cases, several themes emerged:

- False forensic "matches." In more than a third of the forensic fraud cases analysts and other witnesses falsely linked the defendants to crime scene evidence (27/75), most often by claiming that their hair "matched" hair from the crime scene (10/27). For example, at Glen Woodall's 1987 rape trial, West Virginia State Police Trooper Fred Zain testified that it was "highly unlikely" a hair found in the victim's car could have come from any source but Woodall's blond beard-despite the fact that in a concealed report he wrote three months earlier, Zain described that sample as a pubic hair.

In several other cases, the forensic experts falsely reported that blood or semen from the crime scene had the same blood type as the defendants' blood (7/27), or that crime scene DNA matched the defendant (3/27). At Bernard Webster's 1982 rape trial in Maryland, for example, the forensic analyst testified that the rapist had type A blood, as did Webster; in fact, there was no way to determine the blood type of the rapist from the mixed sample that was available-as that same expert had testified earlier.

In a few cases forensic analysts testified falsely that bitemarks on the victims matched the defendants' teeth (4/27), or that tools owned by the defendant damaged the victim's property (2/27), or that a fiber found near the crime was linked to the defendant $(1 / 27)$.

- Concealed tests that excluded the defendant from suspicion. In about a quarter of the cases, forensic witnesses falsely reported that the defendants might have been the source of crime-scene blood, semen or fingerprints, while concealing forensic tests that had already shown that was impossible (17/75). For example, in $1988 \underline{\text { Calvin }}$ and Larry Ollins, Omar Saunders and Marcellius Bradford, ages 14 through 18, were convicted of rape and murder in Chicago. At their trial, forensic analyst Pamela Fish testified that semen found on the victim's body and undergarments could have come from three of the four defendants. In fact, she knew from blood tests that she had conducted and hidden that none of the defendants could have been the source of the semen. 
- Planted evidence. In four exonerations, police planted the evidence that was tested by forensic analysts. In three cases from upstate New York, state troopers planted defendants' fingerprints on objects from the crime scene, and then "collected" and "analyzed" those prints themselves; 113 and in Desmond Ricks' case in Detroit, officers substituted a slug fired from a gun found in Desmond's house for the slug that killed the victim in order to lead another officer and an independent forensic analyst to falsely conclude that Desmond's gun fired the fatal shot.

- Various lies. The remaining third of forensic fraud cases are a mixed bag (27/75). In three cases, for example, the forensic analyst lied and said that there was insufficient trace evidence for forensic testing when in fact there was sufficient evidence to test and, when tests were eventually conducted, they cleared the defendant. And in a twodefendant murder case, an examiner testified falsely that there was no blood spatter on the pants of the primary alternate suspect; testing 18 years later found that there was a spatter of blood on the pants-the victim's blood.

At William Dillon's murder trial in Florida in 1981, a dog handler who was later labeled "a charlatan" by the Arizona Supreme Court testified to a rigged "dog sniff identification" that appeared to implicate Dillon. And in Adolph Munson's 1984 murder case in Oklahoma, Medical Examiner Ralph Erdmann first testified that the victim was killed by a large caliber bullet; then the prosecutors told him that they needed it to be a small .22 caliber bullet, so he revised his testimony and said that maggots had enlarged the .22 caliber holes.

A third of known incidents of forensic fraud involved notorious bad actors (25/75). Dr. Erdmann, for example, eventually lost his medical license and pled guilty to several felonies after it was discovered that he had filed reports on hundreds if not thousands of autopsies that he never conducted. Pamela Fish-who is responsible for 10 of the forensic fraud cases we listwas removed from criminal case work by the Illinois State Police after several cases in which her perjury was exposed ended in exoneration. Fred Zain, who presented fraudulent evidence in seven trials that led to exonerations, was the subject of major investigations for massive patterns of forensic fraud in both West Virginia and Texas, and was eventually indicted for fraud. And Joyce Gilchrist, who committed forensic fraud in three exonerations (and provided false or misleading evidence in three others) was ultimately investigated by the FBI and fired.14

\footnotetext{
113 In the first case, State Police Trooper David Harding testified at Shirley Kinge's arson trial in Tompkins County, New York in 1990, that he found Kinge's fingerprints on a gasoline can at the site of the fire. In 1992, Kinge was exonerated after Harding pled guilty to perjury and admitted planting fingerprint evidence in Kinge's case and others; he was sentenced to $4 \frac{1}{2}$ years in prison. Two years later, William Labolt Jr. was exonerated after an investigation revealed that a Lieutenant in Harding's unit had planted a fingerprint that led to his conviction for burglary; and in 1995, Mark Prentice was exonerated when Trooper Harding admitted to planting the fingerprint that led to his conviction for robbery.

114 For additional references on Pamela Fish, Fred Zain and Joyce Gilchrist, See infra Sections X.2.c, XII.1.c, XII.2.b.i, and XII.2.c.ii(b).
} 
No doubt repeat offenders contribute more than their share of misconduct in this setting, as in others. But we are also more likely to learn about incidents of forensic fraud by serial perjurers who eventually get caught-after which their entire work history is likely to be reexaminedthan about similar acts by colleagues with more discretion or better luck.

\section{FAKE CRIMES}

As ordinary lay witnesses, police and other law enforcement officers manufactured false evidence against innocent defendants in two ways: (i) In about $4 \%$ of exonerations they planted evidence at the scene of the crime and claimed to have found it there; in all but a few of those cases, they planted evidence of crimes that never occurred. (ii) In about $1 \%$ of the cases officers falsely claimed that the defendants assaulted them, usually to cover up for their own violence against the same defendants.

\section{a. Planted evidence}

Planting evidence is a devastating form of misconduct. It occurred in hundreds of group exonerations in which corrupt police officers planted drugs on innocent defendants. As we've discussed, most group exonerations are not included in the Registry, although we do include the Sergeant Watts group exonerations in Chicago-66 so far-and expect to add others. ${ }^{115}$

In addition, police officers planted evidence (usually drugs) in about $1 \%$ of non-group exonerations that we know of $(18 / 1,361)$. For example, at Maurice James's 1990 drug-sale trial in Rochester, New York, a police officer testified that he found a marked \$20 bill on James, which was supposedly used to pay for drugs. James spent two years in prison; he was exonerated after a federal grand jury indicted the officers involved for misconduct in several cases, and one of the officers admitted that he planted the marked bill. In other cases, officers planted illegal drugs on the defendants, or in their cars or homes, or simply booked the drugs in evidence and falsely claimed that they found them in the defendants' possession.

We know of only four non-drug exonerations in which police planted evidence, all cases in which real crimes did occur. In three, New York State troopers planted the exonerees' fingerprints. We discussed them in more detail above, as forensic fraud. ${ }^{116}$ And Marvin Thomas's 1987 murder conviction in West Virginia was based in part on a human bloodstain and hair that were planted in the exoneree's car.

Planted evidence is very hard to detect. If an officer says "I found this bag of white powder (or this hair, or $\$ 20$ bill) on the defendant," how would we ever know that he actually found it in the trunk of his own car? Certainly few judges or prosecutors (nor most defense lawyers) will believe the defendant's claim that he was framed.

Almost all the planted evidence cases we know about occurred in the context of drug crime enforcement. Illegal drug distribution in the United States is a major business that police

\footnotetext{
115 See supra Section III.3.i.

116 See supra Section VI.1.
} 
attempt to prevent, or at least control, with little or no success. Sometimes they succumb to the temptation to simply arrest people they believe sell drugs and make up the evidence. It's easily done. And sometimes-as with Sergeant. Watts and his crew-they decide to make money themselves by extorting or stealing from suspects, or selling drugs they seize. Along the way they may find it useful to frame dozens or hundreds of innocent defendants.

If a widespread pattern of corruption of that sort goes on long enough, it may eventually be detected and the dishonest officers may be brought to justice-after which, many of the convictions they obtained may be reinvestigated, and innocent defendants exonerated. That's what happened after Sergeant Watts was convicted in federal court in Chicago, and in other group exonerations elsewhere.

On a smaller scale, that's what happened in the New York State trooper fingerprint planting cases, which involved dozens of defendants in addition to the three who were exonerated. A special prosecutor who investigated the scandal wrote:

"Some members of the Identification Unit were so careless with their fabrications they left ... 'practice' fabrications behind in the actual case files in which evidence had been fabricated and used in criminal prosecutions. ... [This] strongly suggests that the individuals fabricating evidence on a routine basis had no fear of discovery and ... took few steps to cover their tracks."117

On the other hand, if an officer lies about where he found a gun or a jacket or a quantity of drugs in one or several unrelated investigations, we'll probably never know. We only know about the planted bloodstain and hair in Marvin Thomas's case because they appeared miraculously after the car had been searched twice, by local police and then by the FBI, and nothing of value was found. If they had been planted before the first search, Thomas would probably still be in prison.

\section{b. Phony assaults}

In an important minority of criminal cases, police officers are essential fact witnesses because they are the victims of violent crimes-or claim to be, as in several exonerations in the Registry. For example, Wassillie Gregory, as we saw, ${ }^{118}$ was exonerated in Alaska in 2014 when a surveillance video showed that Gregory was the victim of an assault by the police officer who arrested him, rather than vice versa.

In 1970, Malcolm Emory was walking from the library to his dormitory at Northeastern University in Boston when he passed by an anti-Vietnam war demonstration. He was arrested by an officer who later testified that Emory had a brick in one hand and a concrete block in the other, and struck the officer in the chest with the brick. Emory was convicted of assault and battery with a dangerous weapon on a police officer. He was exonerated 20 years later, after he

117 Nelson E. Roth, "The New York State Police Evidence Tampering Investigation," confidential report to the governor of New York (Ithaca, Jan. 20, 1997) 289. See also Richard Perez-Pena, Supervision of Troopers Faulted In Evidence-Tampering Scandal, The New York Times, Feb. 4, 1997, page B.1.

118 See supra Section I. 
managed to find an unpublished newspaper photograph of the demonstration that clearly shows Emory, as he testified, being beaten and wrestled to the ground by police as he clutches several books, with no brick or concrete block in sight.

In 2006, Daniel Gonzalez, Jonathan Dominguez and Jeffery Funes were convicted in Los Angeles for supposedly throwing a beer bottle that shattered and injured a police officer. After a defense attorney discovered that the bottle in question was still intact, the trial judge declared "I have been flat out lied to," vacated the convictions and dismissed the charges.

In the cases we've mentioned, the defendant was exonerated by physical evidence that contradicted the officer/victim's false story. That seems to be necessary in order to win an exoneration in a case where the supposed victim is a police officer: the undamaged beer bottle in the Gonzalez, Dominguez and Funes case; photographs or videos in the others. The only exception is the case of Jeffrey Santos, who was exonerated in 2004 after the officer he was convicted of assaulting - a captain at the main New York City jail-was investigated and disciplined for a pattern of severe assaults on several prisoners, all similar to the one Santos described at his trial.

Judging from these cases, if an innocent defendant is convicted because a police officer who beat him up lies and says that the defendant was the attacker, he will only be exonerated if he can produce physical evidence that contradicts the police version of events-testimony by civilians won't do it-unless the officer is caught doing the same thing repeatedly.

\section{FABRICATED CONFESSIONS}

Twelve percent of the exonerations in the Registry include false confessions $(292 / 2,400$.) We discuss many of these exonerations in Section $\mathrm{V}$, those in which the innocent defendants really did confess to crimes they did not commit, usually under severe pressure from police officers, ranging up to torture. But we define a "confession" as any statement that is treated as such by law enforcement, and in $12 \%$ of exonerations with false confessions the defendants did not confess at all (36/292). Instead, the police fabricated confessions. Needless to say, none of these "confessions" were recorded or confirmed by any other means.

In several cases the exonerees signed "confessions" but did not know what they were signing. Omar Aguirre, for example, who was interrogated in a murder investigation in Chicago in 1997, did not speak or read English. He was told that he had to sign a document in English in order to go home. It was not read to him, he signed it-and it was introduced at trial as his confession. Meredith Town, on the other hand, did know that he was signing a confession-if not the details of what it said-but he signed it anyway because he was threatened with violence if he refused.

In the great majority of exonerations with fictional confessions, the police fabricated oral confessions out of whole cloth (31/36). Robert Hays, for example, called a police detective in Las Vegas in June 1992 because he had heard that his eight-year old daughter had told the police that he had raped her. Hays denied the charge-which his daughter later recanted, many times, and said her mother had forced her to make-but a detective testified at Hays's trial that he confessed to the crime. Hays was convicted and sentenced to life in prison. In 2007, a federal judge found that the detective lied and made up the confession and that Hays was innocent, and ordered that Hays be released immediately. 
Debra Milke's case is probably the best-known fabricated confession in the Registry:

In 1990, James Styers and Roger Scott were convicted of murdering Debra Milke's four-year-old son, Christopher, in Phoenix, Arizona. Both admitted to participating in the murder and both were sentenced to death. Debra Milke herself was also tried for conspiring with Styers and Scott to kill her own son in order to collect a $\$ 5,000$ life insurance policy, and she too was convicted and sentenced to death.

The only evidence connecting Milke to the murder was a confession that was supposedly obtained by Detective Armando Saldate, Jr. Saldate testified that Milke flashed her breasts, offered him sex if he would not arrest her-and then admitted that she conspired to kill her own son for insurance money. Milke denied that any of that happened. There was no written confession, nobody else witnessed it, and, although Saldate's supervisor specifically instructed him to record the interrogation, he did not do so.

Milke was exonerated 25 years later, after her attorneys uncovered Detective Saldate's extensive history of deception and perjury. A 2003 opinion by the United States Court of Appeals for the Ninth Circuit outlined that history: "[A] five-day suspension for taking 'liberties' with a female motorist and then lying about it to his supervisors; four court cases where judges tossed out confessions or indictments because Saldate lied under oath; and four cases where judges suppressed confessions or vacated convictions because Saldate had violated the [Constitution] in the course of interrogation. ... And it is far from clear that this reflects a full account of Saldate's misconduct as a police officer." ${ }_{119}$

Fabricated confessions are somewhat less common in cases with coercive misconduct in interrogations than in those without, $8 \%$ vs. $17 \%$, both in Chicago (12\% to $29 \%)$-which has extraordinarily high rates of false confessions and misconduct in interrogations ${ }^{120}$-and in the rest of the country (7\% to $15 \%$ ). See Table 17.

\footnotetext{
119 Milke v. Ryan, 711 F.3d 998, 1003 (9th Cir. 2013).

120 See supra Section V.
} 
Table 17: Proportions of Cases with Fabricated Confessions, by Misconduct in Interrogation and Jurisdiction

\begin{tabular}{lcc|c} 
& $\begin{array}{c}\text { Exonerations } \\
\text { in Chicago }\end{array}$ & $\begin{array}{c}\text { Exonerations } \\
\text { Elsewhere }\end{array}$ & $\begin{array}{c}\text { ALL } \\
\text { EXONERATIONS }\end{array}$ \\
\hline $\begin{array}{lcc}\text { Fabrication after Coercive } \\
\text { Misconduct in Interrogation }\end{array}$ & $\begin{array}{c}12 \% \\
(7 / 58)\end{array}$ & $\begin{array}{c}7 \% \\
(7 / 107)\end{array}$ & $\begin{array}{c}8 \% \\
(14 / 165)\end{array}$ \\
\hline Fabrication without Coercive & $29 \%$ & $15 \%$ & $17 \%$ \\
Misconduct in Interrogations & $(5 / 17)$ & $(17 / 110)$ & $(22 / 127)$ \\
\hline ALL FABRICATED & $16 \%$ & $11 \%$ & $12 \%$ \\
CONFESSIONS & $(12 / 75)$ & $(24 / 217)$ & $(36 / 292)$ \\
\hline
\end{tabular}

Perhaps the reason for this difference is that coercion (especially violence) and fabrication are usually alternative means to the same end: producing a "confession" to use in court. Officers who are reluctant to use violence may be driven to make up confessions that never happened, while those who are proficient at violence, or other types of coercion, usually get suspects to say or sign what that want, and have no need to cook up confessions from scratch.

But when coercion-extreme coercion-fails to produce results, fabrication may follow:

In January of 1982, a prosecution witness in an upcoming murder trial in Chicago was shot to death. Detectives arrested Melvin Jones while he was babysitting his girlfriend's child, and found a gun in a drawer in the child's room. Police Lt. Jon Burge and his officers abused Jones for days. They administered electrical shocks to his feet, thighs and penis, and hit him on the head with a stapler-but he didn't confess. After four days, they gave up and charged Jones with unlawful use of a weapon, for which he was acquitted.

A few months later, police arrested Jones for an unrelated triple homicide, but never charged him with those murders. Instead, after another interrogation, they charged him with the earlier murder. Detectives said Jones confessed to that murder because he believed he had gotten away with it and could no longer be charged.

There was no recording of the confession, and no written record. At one point, the police called in a prosecutor to "take the confession," but Jones told the prosecutor he had not confessed. The officers later said that after the prosecutor left, Jones confessed to them again, orally-but they did not record it.

Jones was convicted based on the detectives' testimony that he confessed-which he denied-and testimony from an officer that an eyewitness who had identified 
Jones had passed a polygraph test. ${ }^{121}$ Jones was acquitted on retrial after the "eyewitness" testified she had not been polygraphed and had never identified Jones. There was no evidence that she had-other than the officers' words.

Jones is not alone. In more than $70 \%$ of exonerations with fabricated confessions that were preceded by abusive but unsuccessful interrogations, those interrogations included actual or threatened violence (10/14).

In other cases, misconduct in interrogation and fabrication are two parts of a single course of action. Charles Johnson, for example, was interrogated for a murder he did not commit, in handcuffs, for twelve hours. Chicago detectives told him that if he did not "tell the truth" he would "never see his family again," would get the death penalty, and would be raped in prison. At the end of that ordeal, he signed - without reading - a few documents that were said to be "release papers." One was a confession written by the police. When an officer read it to him, he said "I didn't tell you that, I told you nothing"-but it sent him to prison for 19 years before he was exonerated.

121 The eyewitness did not testify at that trial. The conviction was vacated in part because the police officer's testimony about her supposed identification was inadmissible hearsay. 


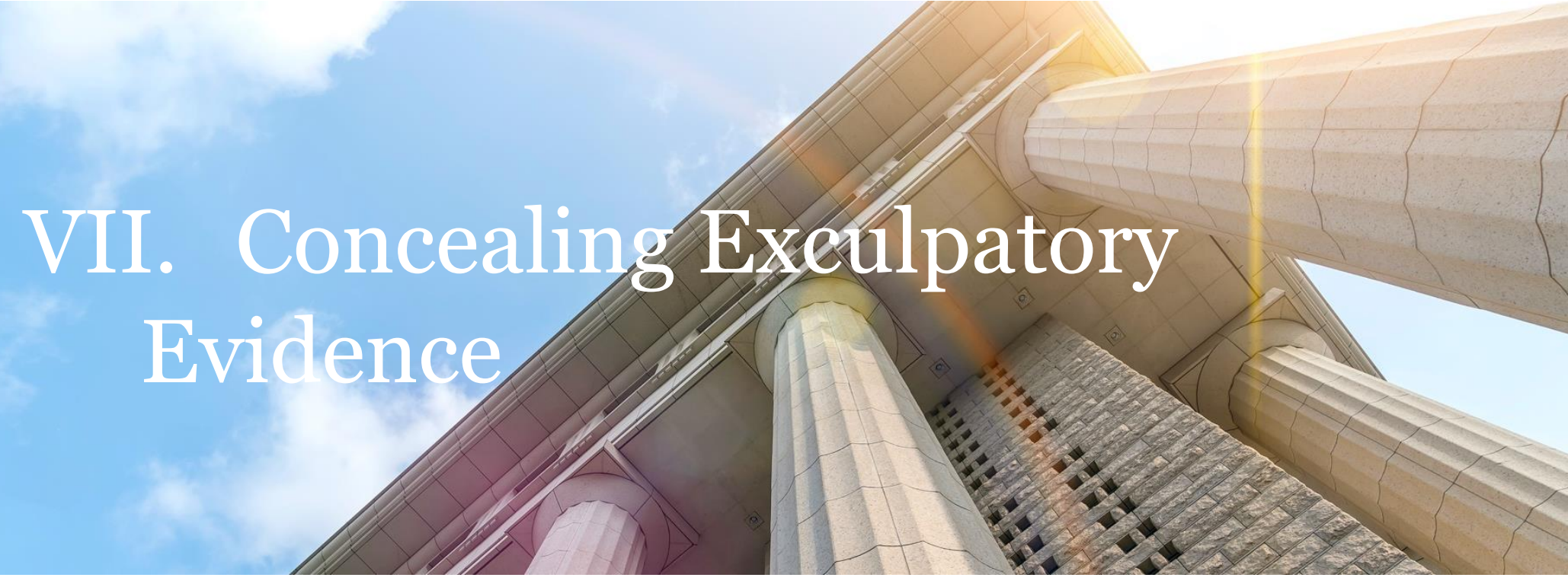

In 1987, in Williamson County, Texas, Michael Morton was convicted of murdering his wife, Christine, by bludgeoning her to death in their bed. He was exonerated in 2011, 24 years later, when DNA tests were conducted on a bandana found 100 yards from the Mortons' house. ${ }^{122}$ That testing found Christine Morton's blood on the bandana together with DNA from a convicted felon, who later bludgeoned another woman to death in her bed in nearby Travis County in 1988, while Michael Morton was in prison. For years, the prosecution had opposed testing the bandana.

In the process of reinvestigating the case, lawyers for Morton also found the following items of information that were well known to police and prosecutors but had been concealed from the defense at trial: (i) Neighbors told police that in the days before the murder they saw a man park a green van, get out, and walk into the woods behind the Mortons' house. (ii) Days after the murder, while Morton was in custody, someone attempted to use a credit card belonging to his wife at a store in San Antonio, Texas. (iii) Weeks later, a $\$ 20$ check written to Christine that had been in her missing purse was cashed with a forged signature. (iv) Christine's mother reported to the police that the Mortons' three-year-old son, her grandson, had told her that "a monster" killed his mother when "Daddy" was not there.

Michael Morton's exoneration is one of the best known in the Registry. The misconduct was blatant, and the consequences horrific. If the police had followed the leads they concealed rather than hiding them in order to convict Morton, they might have identified the real killer before he murdered another woman in a similar manner-and of course, spared Morton and his family from the horror of his false conviction. Morton's case has been the subject of at least one book, ${ }^{123}$

122 See Annie Daniel \& Johnathan Silver, From Michael Morton's Wrongful Conviction to Exoneration (Timeline), The Tex. Trib. (Aug. 13, 2016).

123 Michael Morton, Getting Life: An Innocent Man's 25-Year Journey from Prison to Peace (2014). 
an award winning-documentary, ${ }^{124}$ and countless podcasts and news stories. In 2013, the Texas Legislature passed the "Michael Morton Act" which requires prosecutors in Texas to provide extensive information about criminal investigations to the defense before trial. ${ }^{125}$

Quedillis Ricardo Walker's case, by contrast, is obscure.

In 1991, Walker went on trial for the murder of a former girlfriend who was found dead in her apartment in Cupertino, California-bound, gagged and stabbed. The main evidence against Walker came from a codefendant, Rahsson Bowers, whose fingerprints were found on duct tape that was used to bind the victim. Bowers pled guilty to second-degree murder during the trial, and testified that he helped Walker kill the victim because he was afraid of him.

In addition, Sarah Dunbar, an acquaintance of Walker's, testified that Walker had threatened her with a knife and a gun, and that she had bought him a pair of gloves that were similar to a piece of a glove found near the body. Walker was convicted of first-degree murder.

Twelve years later, Dunbar admitted that she had lied in her testimony against Walker in return for a deal on pending drug charges-a deal that was concealed at trial. Walker was exonerated after several witnesses identified a different man as Bowers' accomplice, and that man's DNA was found at the scene of the killing.

The concealed evidence that we know about is much more mundane in Walker's case than in Morton's. There was nothing that directly indicated that someone else was the killer, just a hidden reason to distrust a witness against Walker. But the rest of the case against Walker was weak; it consisted of little more than the testimony of an admitted murderer who got years off his sentence in return. Hiding the deal with Dunbar might well have made the difference between conviction and acquittal. In any event, the outcome was the same: an innocent man was convicted of murder.

Note the qualification in the previous paragraph: "The concealed evidence that we know about...." The essence of this type of misconduct is the effort to conceal; we only know about it when that effort eventually fails. Exculpatory evidence that we don't know about may also have been concealed at Quedillis Walker's trial-and at Michael Morton's-not to mention in many other cases where no concealed evidence has come to light.

Even so, concealing exculpatory evidence is the most common type of official misconduct that we report. It was done in $44 \%$ of the exonerations in the Registry $(1,064 / 2,400)$ - that we know about.

${ }^{124}$ An Unreal Dream: The Michael Morton Story (Al Reinert) (2013).

125 Legislative Reference Library of Texas, SB 1611, 83rd Regular Session; see Brandi Grissom, Perry Signs Michael Morton Act, The Texas Tribune, May 16, 2013. 


\section{THE DUTY TO DISCLOSE EXCULPATORY EVIDENCE}

In 1963, the Supreme Court held in Brady v. Maryland that "suppression by the prosecution of evidence favorable to the accused ... violate[s] due process where the evidence is material either to guilt or to punishment." ${ }^{126}$ Brady was decided at a time when pre-trial discovery in criminal cases in the United States was in its infancy. It quickly became-and has remained-the central point of reference for discussions of the government's duty to disclose exculpatory information to criminal defendants. Failure to do so is routinely described as a "Brady violation" and the information at stake is often described as "Brady material."

That framework is unfortunate and misleading for two reasons: (i) The requirements for disclosure under Brady are limited and incoherent. (ii) Other rules-including rules governing discovery in criminal cases and rules of professional responsibility that govern the conduct of prosecutors-require the disclosure of evidence favorable to criminal defendants in broader and clearer terms.

\section{a. Brady v. Maryland and the "Materiality" Requirement}

Under Brady, the obligation to disclose is limited to information that is "material" to the defendant's guilt or punishment. "Materiality" is a term that means different things in different legal contexts. As used in Brady itself, the most likely meaning was one that was current at that time as a requirement for admissibility of evidence: An item of evidence is "material" if some proposition that it tends to prove matters to the resolution of the case at hand; otherwise, the evidence is inadmissible because it's "immaterial." 127

In 1985, however, in United States $v$. Bagley, ${ }^{128}$ the Court introduced a new definition of "materiality" as applied to Brady violations. It held that under Brady, exculpatory evidence "is material only if there is a reasonable probability that, had the evidence been disclosed to the defense, the result of the proceeding would have been different." This sounds like a "harmless error" rule, a judgment that sometimes a constitutional violation does not require reversal of a conviction because the outcome of the case would have been the same without the violation. But it's not. If the evidence is "immaterial" there is no obligation to disclose it; failure to do so is not a forgivable violation of the constitution rule but, no violation at all.

The materiality requirement of the Brady rule, as interpreted by Bagley, is incoherent. ${ }^{129}$ First, how can anyone know whether a jury would have decided a case differently if it had additional evidence? This is a problem with real "harmless error" rules as well, which the Court has attempted to address by setting a very high standard for a finding of harmlessness. In general, a violation of the constitution is only "harmless" if a court reviewing all the evidence in the case

\footnotetext{
${ }^{126}$ Brady v. Maryland, 373 U.S. 83, 87 (1963).

127 See United States v. Bagley, 473 U.S. 667, 703, n.5 (1985) (Marshall, J., dissenting). Under modern codified rules of evidence, materiality in this sense has been absorbed into the more general concept of "relevance." See, e.g., Notes of Advisory Committee on Proposed Rules, Fed. R. Evid. 401.

128 United States v. Bagley, 473 U.S. 667 (1985).

129 See Bagley, 473 U.S. at 687-709 (Marshall, J., dissenting).
} 
concludes "beyond a reasonable doubt" that the violation did not affect the outcome. ${ }^{130}$ Bagley goes far in the opposite direction.

Failure to disclose exculpatory evidence is only subject to the rule if there is "a reasonable probability" that disclosure would have changed the outcome. Under the best of circumstances, this rule will lead to unpredictable and inconsistent outcomes-and circumstances are often far from the best.

Judges don't like to reverse criminal convictions. They believe the defendants are probably guilty, and reversals lead to more work: retrials of the defendants (unless charges are dismissed outright), more appeals by other convicted defendants who draw hope from the reversals, and (if they're consistent) more reversals in future cases. As Judge Kozinski of the United States Court of Appeals for the Ninth Circuit pointed out, courts can avoid these dangers by requiring an "impossibly high" standard for materiality before a conviction will be reversed. ${ }^{131}$

Second, how can a prosecutor be expected to make that judgment? ${ }^{132}$ It seems illogical, but under Bagley the prosecutor is the person who must determine whether the exculpatory evidence is "material." If she concludes that there is no "reasonable probability" that the evidence would change the outcome, then she need not tell anybody about it, and, very likely, neither the defense nor the courts will ever learn that the evidence exists. But the prosecutor is an adversary in the case; her job will always be easier if she decides there is no obligation to disclose, and even if she tries her best to make that decision in good faith, she is biased. Trial lawyers are generally optimistic about their prospects at trial. It's a posture that helps them win by projecting confidence-especially if they actually do feel confident that they will win, whether or not they are right. But that same optimism may also lead a prosecutor to be confident that exculpatory evidence that only she knows about would not affect the jury's decision.

Third, how can a prosecutor-or anybody-possibly make that determination before trial? For the disclosure required by Brady to be effective, it must be made before trial, or perhaps at the very outset of a trial. At that point, the prosecutor cannot possibly know what evidence the jury will hear. Her own witnesses may change their stories, or add new information, or be damaged on cross-examination-or in some cases, fail to testify at all-and she will at best only be able to guess whether the defendant himself will testify, or who else will testify for the defense, or what the defense witnesses will say and how they will come off. She certainly can't know how the defense might use the exculpatory evidence if revealed: Would it open up new avenues of investigation? Would it lead to new witnesses the prosecutor does not know about? In any case

130 Chapman v. California, 386 U.S. 18 (1967).

131 United States v. Olsen, 737 F.3d 625, 633 (9th Cir. 2013).

132 See David A. Sklansky, The Progressive Prosecutor's Handbook, 50 U.C. Davis L. Rev. Online 25, 34 (2017). 
where guilt or innocence is truly in dispute, nobody can say at the outset of the trial how strong the evidence of guilt will be at the end. ${ }^{133}$

Unsurprisingly, the "materiality" requirement that Bagley and other cases applied to the requirement of disclosure of exculpatory evidence under Brady has been the subject of extensive criticism by legal scholars. ${ }^{134}$

\section{b. Other Legal Bases for the Duty to Disclose}

i. Professional Responsibility

The Brady decision was not about misconduct by the prosecutor or any other government official. The issue, rather, was whether the defendant received a fair trial. As the Supreme Court explained in 1988, in Youngblood v. Arizona, "The Due Process Clause of the Fourteenth Amendment, as interpreted in Brady, makes the good or bad faith of the State irrelevant when the State fails to disclose to the defendant material exculpatory evidence." 135 This does not mean that failing to comply with Brady is not misconduct-it usually is-but rather that this constitutional doctrine is not designed to address the misconduct but to remedy violations of due process of law.

There are, however, other rules that regulate the conduct of prosecutors directly, and specifically require them to disclose exculpatory evidence to the defense regardless of "materiality." Violating those rules is misconduct by any definition. ${ }^{136}$

Rule 3.8 of the American Bar Association (“ABA”) Model Rules of Professional Responsibility provides in part:

The prosecutor in a criminal case shall:

(d) make timely disclosure to the defense of all evidence or information known to the prosecutor that tends to negate the guilt of the accused or mitigates the offense, and, in connection with sentencing, disclose to the defense and to the tribunal all unprivileged

133 See John G. Douglass, Fatal Attraction? The Uneasy Courtship of Brady and Plea Bargaining, 50 Emory L. J. 437, 516 (2001) ("Brady suffers from a severe case of bad timing. Brady establishes a retrospective standard for defining a prospective obligation.")

134 E.g., David A. Sklansky, The Problems with Prosecutors, 1 Ann. Rev. Criminology 451-69 (2018) at 456-58; David A. Sklansky, The Progressive Prosecutor's Handbook, 50 U.C. Davis L. Rev. Online 25, 33-36 (2017); Bennett Gershman, Litigating Brady v. Maryland: Games Prosecutors Play, 57 Case W. Res. L. Rev. 531-66 (2007); Alafair Burke, Revisiting Prosecutorial Disclosure, 84 Ind. L .J. 481 (2009).

135 Arizona v. Youngblood, 488 U.S. 51, 57 (1988).

${ }^{136}$ For an excellent summary of the professional and criminal procedure rules that require prosecutors to disclosed exculpatory evidence to criminal defendants, See Marc Allen, Non-Brady Legal and Ethical Obligations on Prosecutors to Disclose Exculpatory Evidence, National Registry of Exonerations (July, 2018). 
mitigating information known to the prosecutor, except when the prosecutor is relieved of this responsibility by a protective order of the tribunal....

Every state has adopted section (d) of Model Rule 3.8, or a similar standard; none include any requirement of "materiality." 137

\section{ii. Pretrial Discovery}

The ABA has also issued a set of more specific Criminal Justice Standards for the Prosecution Function that are intended to be read as best practices for prosecutors and are meant to supplement the Model Rules for Professional Conduct as they bear on prosecutors. ${ }^{138}$ Standard 3-5.4 deals with disclosure of exculpatory evidence, and explicitly rejects materiality as a condition for disclosure: "Before trial of a criminal case, a prosecutor should make timely disclosure to the defense of [exculpatory] information ... that is known to the prosecutor, regardless of whether the prosecutor believes it is likely to change the result of the proceeding." 139

The ABA Criminal Justice Standards also include a section on pre-trial discovery. Standard 112.1 of the Standards on Discovery provides that:

a) The prosecution should, within a specified and reasonable time prior to trial, disclose to the defense the following information...

(viii) Any material or information within the prosecutor's possession or control which tends to negate the guilt of the defendant as to the offense charged or which would tend to reduce the punishment of the defendant.

State law on pre-trial discovery in criminal cases is uneven. ${ }^{140}$ Thirty-four states have discovery rules that require prosecutors to disclose exculpatory evidence to defendants in all cases or alternatively upon motion by the defense. None of these rules include materiality as a condition for this obligation, although Louisiana and New Hampshire refer to Brady in their definitions of exculpatory evidence-which could be interpreted as incorporating Brady's materiality

137 See id. at 5-7, Table 1.

${ }^{138}$ Criminal Justice Standards for the Prosecution Function § 3-1.1(b) (Am. Bar Ass'n 2017).

139 Id. at § 3-5.4(c). Standard 3-5.4 includes other relevant language as well:

a. After charges are filed if not before, the prosecutor should diligently seek to identify all information in the possession of the prosecution or its agents that tends to negate the guilt of the accused, mitigate the offense charged, impeach the government's witnesses or evidence, or reduce the likely punishment of the accused if convicted.

b. The prosecutor should diligently advise other governmental agencies involved in the case of their continuing duty to identify, preserve, and disclose to the prosecutor information described in (a) above. Before trial of a criminal case, a prosecutor should make timely disclosure to the defense of information described in (a) above that is known to the prosecutor, regardless of whether the prosecutor believes it is likely to change the result of the proceeding, unless relieved of this responsibility by a court's protective order. ...

140 See Allen, supra note 136. 
requirement-while West Virginia's discovery statute, which also refers to Brady, explicitly rejects materiality as limitation.

In short, these rules of professional responsibility and pre-trial discovery impose on prosecutors a stronger, clearer, and more administrable obligation to disclose exculpatory evidence. Why then does Brady dominate the discussion of the issue?

The answer is simple: The remedies. Brady, as we said, describes a requirement of due process. As a result, a proven violation of the rule in Brady-however arbitrary and inconsistent that rule may be in practice-requires reversal of a criminal conviction and can lead to civil liability for violating the defendant's constitutional rights. Violations of non-constitutional rules of professional responsibility rarely have such consequences. ${ }^{141}$

For this study, however, we are concerned with misconduct itself rather than the legal remedies that are sometimes applied in response. For that purpose, we define the duty to disclose exculpatory evidence as it is described in the prevailing rules of professional responsibility and discovery, with no special requirement of "materiality." These rules, as written, apply to prosecutors, but most of the evidence at issue is generated by police and forensic analysts (and in some cases, child welfare workers)-which implies that other law enforcement officers have a duty to inform prosecutors of exculpatory evidence.

Concealing exculpatory evidence may be done intentionally or unintentionally. Unlike the duty to speak the truth that is behind rules against perjury, the obligation here is in some respects technical. Officers and prosecutors are more likely to misunderstand or forget it-or they may misunderstand or forget reports or exhibits they saw, or fail to prepare and remain unaware of evidence they should have noticed and acted on. These are not complete excuses. It is no defense to a failure to disclose exculpatory evidence to say "I never read my own file"-but (if true) it may mean that exculpatory evidence in that file was concealed by culpable neglect rather than deliberate choice.

141 See Strickland v. Washington, 466 U.S. 668, 688-89 (1984). 


\section{CONCEALING EXCULPATORY EVIDENCE, BY CRIME}

The rate of concealing exculpatory evidence varies greatly by crime, as we see in Table 18 .

\section{Table 18: Rate of Concealing Exculpatory Evidence, by Crime}

\begin{tabular}{ll} 
Murder (908) & $61 \%$ \\
\hline Child Sex Abuse (270) & $27 \%$ \\
\hline Sexual Assault (320) & $32 \%$ \\
\hline Robbery (122) & $28 \%$ \\
\hline Other Violent Crimes (270) & $44 \%$ \\
\hline \multicolumn{1}{|c|}{ Felonious Assault (82) } & $54 \%$ \\
\hline \multicolumn{1}{|c}{ Attempted Murder (50) } & $40 \%$ \\
\hline \multicolumn{1}{|c}{ Manslaughter (45) } & $42 \%$ \\
\hline Drug Crimes (317) & $37 \%$ \\
\hline White-collar Crimes (63) & $46 \%$ \\
\hline Other Non-Violent Crimes (130) & $28 \%$ \\
\hline ALL CRIMES (2,400) & $44 \%$ \\
\hline
\end{tabular}

As we mentioned, concealing exculpatory evidence is the most frequent type of official misconduct among known exonerations. It's most common in murder cases-like misconduct in general. Exculpatory evidence was concealed in $82 \%$ of exonerations with any official misconduct (1064/1296).

Concealing exculpatory evidence is not only the most frequent type of misconduct we study but also the most complex. In the sections that follow we discuss who did the concealing, what they concealed, and how they did it.

\section{WHO DOES THE CONCEALING?}

At Steven Crawford's 1974 murder trial in Harrisburg, Pennsylvania, a forensic analyst for the Pennsylvania State Police testified that Crawford left a bloody palm print on a car at the scene of the crime because there was blood on his hand before he touched the car-a critical conclusion that supported the prosecution's theory of the crime. Crawford was exonerated in 2002 after a copy of the original report that the analyst submitted to the prosecutor was discovered. It indicated that, as the defense claimed, the blood was already on the car when Crawford 
touched it, not on his hand. The analyst had altered the report she presented in court in order to help obtain a conviction. ${ }^{142}$

The forensic analyst in Crawford's case committed perjury and forensic fraud. Her misconduct probably sent an innocent man to prison for decades. Nonetheless, as we categorize these cases, she did not conceal exculpatory evidence. She told the prosecutor about the exculpatory conclusion-it was in her original report to him. The prosecutor is the government official who is responsible for all dealings with courts and with defense attorneys; informing them of exculpatory evidence is his responsibility. As far as the duty to disclose goes, the forensic analyst did her part by informing the prosecutor.

Given their role, it's not surprising that prosecutors were responsible for concealing evidence in $73 \%$ of exonerations in which it happened $(378 / 520)$. On the contrary, it's surprising that police were responsible for concealing exculpatory evidence in $33 \%$ of exonerations where it occurred $(172 / 520)$, forensic analysts in $6 \%(29 / 520)$, and about $11 \%$ had more than one type of official participate in concealing evidence. ${ }^{143}$

In each of those cases, police officers (and occasionally forensic analysts) either hid the exculpatory evidence from the prosecution as well as the defense, or informed prosecutors without leaving a record that we know of. Eric Robinson's case is an extreme example:

In July 1993, Eric Robinson was arrested for a drive-by shooting in Los Angeles; in June 1994 he was convicted of murder. Robinson was exonerated in 2006 after his attorneys obtained the complete police file for the case and discovered that within days of his arrest the police had excluded him as a suspect; that months before his trial police Sergeant Mark Arneson learned the identity of the real shooter; and that Sergeant Arneson threatened to arrest witnesses or beat them, or both, if they did not identify Robinson. All of this was hidden from the prosecution as well as the defense.

In some cases both the prosecutor and the police officer involved concealed different items of exculpatory evidence. Dwight Love, for example, was convicted of murder in Detroit in 1982 primarily on the testimony of the surviving victim of an armed robbery in which one victim was killed; he was exonerated in 2001 after the real killer confessed. In the process, defense attorneys discovered that the prosecutor had concealed police reports with descriptions of a killer who looked nothing like Love. In addition, a police officer had threatened to arrest Love's girlfriend if she did not contradict Love's alibi, and hid earlier statements in which she

\footnotetext{
142 The briefcase was discovered by a stroke of unlikely luck. "In 2001 a discarded briefcase that had belonged to a detective in the case was found by two youths rummaging through a dumpster. It contained information about the case, including a copy of the original report prepared by Janice Roadcap, the state police chemist." See Steven Crawford.

143 This Section and Sections VII.4.a and VII.4.b do not include cases where the exculpatory evidence that was concealed was evidence of other misconduct, which are discussed in Section VII.4.c. Except for Section VII.5.b.v, on concealing evidence that no crime in fact occurred, all the proportions in the remainder of Section VII are based on the analysis of the first 1362 exonerations pasted in the Registry; see Section II.2.a.
} 
corroborated that alibi. The prosecutor was unaware of the evidence concealed by the officer-as far as we know.

\section{WHAT WAS CONCEALED?}

a. Objects vs. Information

In May 1989, James Richardson Jr. rescued a three-year-old from a burning house next door to his own home in Cross Lanes, West Virginia, and called the police, who found the girl's mother bound, raped and beaten to death in the house. They arrested Richardson for murder. Richardson was convicted based in part on testimony from Fred Zain, a state police forensic analyst who later became notorious for rampant fraud, perjury and incompetence. ${ }^{144}$ In the aftermath of Zain's exposure, Richardson's case was re-examined and the defense discovered that the police had concealed a blood-covered flashlight they found at the scene. DNA testing of the blood showed that it came from someone other than Richardson or the victim. Richardson was exonerated in 1999.

In Richardson's case, the police concealed a tangible object-the blood-covered flashlight. When discovered, it cleared him. Objects seem like the obvious sort of things to conceal, but in fact that only happened in $13 \%$ of exonerations in which exculpatory evidence was hidden $(66 / 520)$. Concealing information about what a person perceived, believed, knew, said or wrote happened in almost all of those cases. ${ }^{145}$

Concealing an object means hiding or destroying the object itself. In Richardson's case, it was the bloody flashlight, a physical entity that could have been subjected to tests that would have cleared him.

By comparison, when Ulysses Charles was tried for sexual assault in Boston in 1984, a forensic analyst testified that he found no seminal fluid on a vaginal swab of the victim, leading him to conclude that the rapist had not ejaculated. That was a lie. In fact, that analyst had found seminal fluid on the swab that came from a person with blood type $\mathrm{O}$-which meant that Charles, whose blood type was $\mathrm{B}$, could not have committed the rape. The damage from that lie was as catastrophic as the misconduct in Richardson's case, but it consisted of concealing information about an object, the results of the tests on the swab rather than the swab itself.

Nearly $40 \%$ of the few exculpatory objects that we know were concealed, altered or destroyed (25/66) were directly associated with the crime, or were said to be. They included actual murder weapons-or in one case (Michael Pardue), an old shotgun that was cleaned so it looked like it might have been fired recently and therefore could have been the murder weapon; biological trace evidence; clothing; stolen checks; and so forth. Another third (23/66) were photographs or

\footnotetext{
144 See supra Section IV.1, and infra Section X.2.c.

145 In this context, a witness statement on paper or in any electronic format is classified as evidence of the underlying statement, a form of "information," rather than as an "object"-although, of course, it is that too. A surreptitious video or audio recording of a person who is not talking to a law enforcement officer-or who doesn't know that the person he or she is talking to is an officer-is not a witness statement and is classified as physical evidence.
} 
videos connected to the crime, or in a couple of cases, surveillance tapes that showed the defendant at a location away from the crime scene at about the time the crime occurred.

Why do we know of so few cases in which exculpatory objects were concealed? Part of the answer may be that most evidence in all trials, criminal and civil alike, is "testimonial" - what a person says orally or in writing-rather than "real," a physical object that's connected to the case. With more items of information to work with, there are more opportunities to conceal.

Another possibility is that concealed physical evidence is often impossible to detect because many objects can easily be discarded or destroyed. If the flashlight in Richardson's case had been tossed in a river (or in a dumpster, most likely) the defense would never have known about it, and James Richardson might still be in prison.

There are only two exonerations in which we know that items of physical evidence from the crime scenes were successfully discarded or destroyed. ${ }^{146}$ In one, it was hair from the crime scene and a photograph of the victim's body (Clarence Brandley); in the other, it was the hat and jacket that the defendant was wearing when he was arrested (Christopher Harding). We have no idea how many other troublesome objects disappeared without a trace in the investigations of other defendants who were convicted and later exonerated.

Information, on the other hand, may be difficult to hide or destroy for at least three reasons:

(i) If the information is recorded-as a witness statement, in a report, in an invoice, as a business record, and so forth-it's common to create multiple copies, one of which may later turn up. In Steven Crawford's case it took a stroke of unlikely luck. Twenty-seven years after he was convicted of murder, a discarded briefcase that had belonged to a detective in the case was found by accident in a dumpster; it contained information about the case, including a copy of a concealed forensic report by a state police chemist that undermined the prosecution's case. Usually, the copy is just found in somebody's file.

Or on a computer drive. If a statement or report is entered in a computer, there may be electronic copies in unreachable or unforeseen locations, especially if it was transmitted to other computers. It may be impossible to delete all copies.

(ii) Recorded information in a criminal investigation is usually evidence of what a person said or wrote at some past time and place. Even if that statement is successfully hidden, the witness herself may still be accessible and willing to say what she knows. For example, before Brad Childers was convicted of a string of robberies in Texas in 2004, the real robber, Jonathan Clark, was arrested for other similar robberies and confessed to those that Childers was charged with as well-but that confession was concealed. Ten years later, investigators hired by Childers' family found Clark in prison, and he told them that he had committed the robberies Childers

\footnotetext{
146 In Madison Hobley's case, a gas can that was said to be linked to the arson murder of which she was convicted was destroyed without fingerprinting, but the existence of the can was not concealed; in fact, the can had been subpoenaed by the defense-and a court later ruled the destruction was not done in bad faith, and therefore was not misconduct.
} 
was imprisoned for, and that he had told that to the police in 2002. A bloody flashlight in a landfill can't do that.

(iii) Information is often shared, in two senses. Some facts are known by multiple people from their inception-the five officers who worked with a particular detective in a given year, or the three witnesses to a robbery. And some facts that are initially known to only one person-who set fire to the barn-become more widely known if the original witness shares them with others after the event.

\section{b. Substantive Evidence vs. Impeachment}

Evidence at trial can serve two distinct functions:

- Substantive evidence helps prove an issue at stake in a trial directly. In Michael Morton's case, for example, the concealed evidence that someone used his dead wife's credit card while he was in jail made it more likely that he was innocent because it meant that someone else had access to that card after her death-the killer or someone who got the card from the killer. That is substantive evidence of innocence.

Evidence that neighbors saw a strange man with a green van hanging around the Morton house before the murder was also substantive evidence of Morton's innocence because that unknown man was a potential suspect. It's weaker evidence than the credit card use, but this classification does not turn on the power of an item of evidence but on what it helps prove. The test is whether the evidence would have helped the defense at trial regardless of who testified for the state. If so, it's substantive

- Impeachment evidence challenges the credibility of a prosecution witness who has already testified. At Quedillis Walker's trial, for example, Sarah Dunbar testified that Walker was a violent man, and that he had gloves similar to ones that might have been used in the murder-two items of circumstantial evidence that suggest that he might be guilty, if they are true. The fact that Dunbar made a deal with the prosecution would have been relevant at trial not because it bears on Walker's behavior, but because it casts doubt on the truthfulness of Dunbar's sworn testimony.

Evidence of Dunbar's deal was only admissible at trial because she testified for the prosecution, in order to show that she lied. If she had not testified, it would have no bearing on the case. That's the test for whether evidence is used solely for impeachment.

Some concealed evidence falls exclusively into one or another of these categories. For example, the prosecutor in Kenneth Kagonyera's case concealed a confession by the true perpetrator, a DNA report that excluded Kagonyera, and taped over and destroyed part of a surveillance video that could have cleared Kagonyera and his codefendants. Each of these items stands on its own as substantive evidence of innocence. In Gerald Atlas's case, on the other hand, the prosecution concealed evidence that a critical eyewitness was on felony probation, and that he had a history of drug addiction. Neither of those facts in themselves points to Gerald's innocence, but they do suggest that the prosecution witness may not have told the truth.

Not all concealed evidence fits neatly into a single category. In William Harris's case in West Virginia, for example, an eyewitness told the police, before she picked Harris out of a lineup, 
that she knew Harris and that he wasn't the attacker. If the defense had known about that information, they could have used it as substantive evidence that Harris was innocent-and also to impeach that eyewitness's later identification of Harris at trial.

Almost all of the small number of concealed exculpatory objects that we know of-the surveillance video in Kenneth Kagonyera's case, for the example-were substantive evidence of innocence (62/66). Only a few concealed objects were relevant to impeachment only. In Jesus Ramirez and Alberto Sifuentes' case in Littlefield, Texas, for example, the prosecution concealed a video that impeached a critical eyewitness by showing her at the crime scene an hour and a half before she said she was there.

The much larger set of concealed information is a mixed bag. Impeachment evidence was hidden in $80 \%$ of exonerations with concealed exculpatory evidence (416/520); substantive exculpatory evidence was concealed in 63\% (325/520); and both types were concealed in 50\% (262/520).147 Prosecutors were responsible for concealing information in about two-thirds of the cases, both those with concealed impeachment (286/416) and those with concealed substantive evidence of innocence (218/325).

\section{c. Concealing Other Misconduct}

At about 10 p.m. on August 21, 2003, Noris Hilde and his wife Sherl were shot in their trailer at a campground in Umpqua National Forest, in Oregon. Noris was killed; Sherl was critically wounded but survived. Samuel Lawson, who had been at the campground that morning, was charged with murder and attempted murder.

Sherl Hilde failed to identify Lawson several times while she was recuperating, and told the police that she did not see the shooter, but at his trial in 2005 she identified Lawson as the man who shot her and her husband. Asked if she had any doubt, Sherl said, "Absolutely not. I'll never forget his face as long as I live." She also said that she "always knew it was him." No physical evidence and no other witnesses tied Lawson to the crime, but he was convicted and sentenced to life in prison.

In 2012, the Oregon Supreme Court reversed Lawson's conviction because Sherl Hilde's identification of Lawson was obtained by unduly suggestive procedures. Sherl had been repeatedly shown different photographic lineups, each of which included a picture of Lawson but otherwise pictured different men than the other lineups. In addition, a detective took Sherl to court to view Lawson in person prior to trial, and, before testifying, she was given a single photograph of Lawson wearing the same clothes he wore when Sherl saw him the morning before the shooting. In 2014, charges were dismissed and Lawson was exonerated.

\footnotetext{
147 The substantive evidence includes substantive testimonial evidence, substantive forensic evidence, and substantive physical evidence.
} 
The identification of Samuel Lawson was obtained by police misconduct-deliberately suggestive procedures that were designed to induce Sherl Hilde to identify Lawson despite her repeated failures to do so and her statement that she didn't see the shooter. It was a tainted identification, one of the varieties of false evidence produced by witness tampering, as we have discussed.148 The Oregon Supreme Court reversed Lawson's conviction in part because of that misconduct.

But the court also reversed because the police concealed the improper methods they used to obtain the identification. According to the Oregon Supreme Court, " $\mathrm{t}]$ hat kind of information is essential to an accurate determination of the reliability of an eyewitness's identification and is the kind of potentially exculpatory evidence that the state is constitutionally required to disclose to a defendant." In other words, it was a separate act of misconduct to conceal the misconduct that surrounded the identification because that information might have led the jury to reject Sherl Hilde's testimony and acquit Lawson.

Obviously, a police officer who has done something wrong, perhaps even criminal, is not likely to turn around and tell the world about it. We're all always inclined to conceal our misdeeds, and especially in this context. The goal of the witness tampering in the Hilde murder investigation was to nail Samuel Lawson; telling the world how it was done would defeat the purpose. Nonetheless, concealing the misconduct that led to the identification of Lawson was itself misconduct, as the Oregon Supreme Court said-a form of derivative misconduct.

Derivative misconduct by concealing exculpatory evidence can occur any time the authorities commit another type of misconduct which, if known, might undercut the case against the defendant. That includes any cases in which law enforcement officers fabricated or planted evidence, coerced false confessions from defendants by illegal means, or deliberately tampered with and distorted evidence from victims or third-party witnesses.

The Oregon Supreme Court recognized that witness tampering can also entail a separate form of misconduct-concealing impeachment evidence about the prosecution witness who was tampered with. Most court opinions on official misconduct ignore the issue, understandably: it's easy to overlook since it generally has no consequences for deciding the case once the primary misconduct has been identified.

The opinions we have that do discuss derivative concealing of exculpatory evidence usually focus on concrete records of the misconduct that were concealed-a report or a recording. For example, in 2013 Brandon Lewis was convicted of assaulting three police officers in Payson, Arizona. He was exonerated in 2014 because of newly disclosed evidence that the officers beat Lewis and then lied and said he had assaulted them. The trial judge dismissed the case because the police and prosecutors did not disclose written reports that described the beating (and refuted the officers' sworn testimony): "It is an injustice that so many legally relevant documents were not properly disclosed prior to trial. The failure of due process here is clear." The officers would have been equally guilty of concealing that information if it had not been reduced to

148 See Section IV.3. 
writing, but without those reports who would have believed that the police beat a suspect for no reason and then lied to cover it up?

Exculpatory evidence of other official misconduct was concealed in $26 \%$ of all exonerations, more than half of exonerations with concealed exculpatory evidence (353/66o). Other, "independent" forms of exculpatory evidence were concealed in $38 \%$ of exonerations-almost $80 \%$ of exonerations with any concealed exculpatory evidence $(520 / 660)$, and more cases than any other form of official misconduct. ${ }^{149}$ See Table $19 .{ }^{150}$

\section{Table 19: Concealing Exculpatory Evidence: Rates of Independent and Derivative} Violations $(N=1,361)$

\begin{tabular}{|ll|}
\hline Concealing Exculpatory Evidence (660) & $48 \%$ \\
\hline Independent (520) & $38 \%$ \\
\hline Derivative (353) & $26 \%$ \\
\hline ALL OFFICIAL MISCONDUCT (757) & $56 \%$ \\
\hline
\end{tabular}

More than $60 \%$ of exonerations with derivative concealment also include separate independent acts of concealing exculpatory evidence (213/353). For example:

The 13-year-old victim of the rape for which Peter Rose was falsely convicted in California failed to identify Rose in a photo array. Police officers responded by accusing her of lying and of being a prostitute, and bullied her into making the identification. The police concealed the victim's initial failure to identify Rose, and they concealed the bullying that led to the identification she eventually made. In addition, the prosecution concealed a forensic test on semen recovered from the rape which revealed that the rapist had a different blood type than Rose.

In this case, the police improperly pressured and manipulated the victim to identify Rose, and, predictably, concealed that misconduct-derivative concealment. But they also concealed the fact that the victim initially failed to identify Rose, and the prosecutor concealed a forensic test that cleared Rose entirely-independent concealment.

149 See supra, Table 7, Section III.5.

150 Counting derivative misconduct cannot change the overall proportion of exonerations with official misconduct because, by definition, a case can only include derivative misconduct if it also includes some other known act or acts of misconduct. 


\section{CATEGORIES OF CONCEALED INFORMATION}

\section{a. Impeachment of prosecution witnesses}

Any number of different types of impeachment evidence were concealed in these exonerations. Some would probably have had modest impact, if known; some would have been explosive. In Levon Jones's murder trial in North Carolina in 1993, for example, the defense was not told that a central witness for the prosecution had been paid $\$ 4,000$ as a reward for information about the crime. It's less likely that Jones would have been convicted if that item had been disclosed, but probably not by much. (By the time Jones was exonerated in 2007, however, that same witness had recanted her testimony entirely and disclosed that she had been threatened with prosecution herself if she did not testify against Jones.)

At the other end of the spectrum, the sole eyewitness at Alvena Jennette and Daryl Austin's murder trial in 1988 was also the sole eyewitness who identified other defendants in several earlier unrelated murder trials that had been investigated by the same Brooklyn detective. That single piece of hidden impeachment evidence undermined the prosecution's entire case, and led the Brooklyn District Attorney to dismiss Jennette's and Austin's convictions, and at least three others as well.

A few categories of concealed impeachment evidence show up repeatedly:

\section{i. Incentives to testify}

In a fifth of all exonerations $(281 / 1,361)$, the prosecution concealed an incentive to testify on the part of one or more of their witnesses. Sometimes it was a promise. For example, in Bernard Baran's wrongful prosecution for child sex abuse in Massachusetts in 1985, a video of an interview with a supposed victim was edited to remove the portion where the child-who'd been pressured to accuse Baran - asks "Where's my prize? You promised me a prize."

In other cases, it was a threat. When Adam Miranda was prosecuted for the murder of Robert Hosey in Los Angeles in 1983, for example, the main prosecution witness was told that unless he testified against Miranda, he himself would be prosecuted for that crime.

And sometimes, as in Levon Jones's case, it was both.

The most common concealed incentive to testify falsely is a deal with the prosecutor to dismiss or reduce pending criminal charges against the witness. The witness might be a codefendant charged for the same crime as the exoneree, or she may face unrelated charges.

Michael Hash's 2001 murder trial in Virginia included both types of dishonest witnesses. A codefendant falsely testified that Hash and a third defendant shot the victim; he had a secret deal with the prosecution that reduced his own charge to second-degree murder and his punishment to six years and eight months in prison. In addition, a jailhouse informant falsely testified that Hash confessed to him while in jail; the defense was not told that the informant had an agreement with the prosecutor under which his term in prison was reduced from 15 years to five-or that he had given similar testimony against at least 20 other defendants.

And of course, there's money, from several possible sources: 
After Shawn Lawrence was convicted of murder in Amityville, New York in 2015, his appellate lawyer discovered that the prosecution had paid \$4000 in relocation expenses to a crack addict who testified that he saw Lawrence shoot the victims.

At Perman Pitman's murder trial in New Jersey in 2007, the prosecution hid evidence that the only witness who identified Pitman had been paid to do so by the drug dealers who were trying to muscle the murdered victim out of the drug business.

And at John Thompson's 1985 murder trial in New Orleans, a witness testified that he heard Thompson admit to the killing-but the prosecution concealed a $\$ 15,000$ reward the witness received for his testimony from the victim's family.

ii. Inconsistent statements

In $14 \%$ of the prosecutions of exonerated defendants, the authorities concealed statements by prosecution witnesses that contradicted their testimony at trial $(185 / 1,361)$. For example:

Sandra Craig did not know that the six-year old girl who accused her of child sex abuse in Maryland in 1987 had also identified numerous other people as her abusers and had mistaken someone else for Craig. The prosecutor, who had attended some of the interviews with the girl, did know about these statements and hid them.

James Haley was convicted of murder in Boston in 1972 after the victim's girlfriend and the victim's roommate both testified that they had seen Haley-the roommate's estranged husband-in the neighborhood around the time of the crime. The victim's girlfriend also testified that she saw Haley commit the murder. Haley was sentenced to life imprisonment with no possibility of parole. Thirty-four years later, a public records request by Haley revealed that the prosecution had concealed reports that both women initially told the police they had not seen Haley in over a month.

iii. Criminal records and histories of dishonesty

In about $4 \%$ of the cases, prosecutors (and occasionally, police officers) concealed evidence of crimes or dishonest conduct by state witnesses $(61 / 1,361)$. For example, Paula Hall's murder conviction was reversed in Missouri in 2011 in part because prosecutors failed to disclose that a witness who claimed to have heard Hall confess to the crime had herself been convicted of passing bad checks, forgery and violating probation, and had other charges pending at the time of Hall's trial. And Gerardo Sandoval-Gonzalez's immigration law conviction was dismissed in California in 2012 because the defense was not told that a federal agent who testified against Sandoval-Gonzalez had forged his supervisor's signature on a report in another case.

Some types of concealed impeachment evidence are rare or unique, at least as far as we know, but just as important as more common types in the cases in which they were eventually revealed.

In several cases, police officers concealed sexual affairs with government witnesses. At Raymond Carter's 1988 murder trial in Philadelphia, for example, the sole eyewitness had been in a sexual relationship with the arresting officer for years. 
In the most extraordinary of these cases, five Latino gang members- $\underline{\text { Anthony Adams, Luis }}$ Davalos, Jesse Alvarez, Jorge Alvarez and Cesar Menendez-pled guilty to manslaughter in Los Angeles in 1996 after they had been identified by 18-year-old Sonya Flores. Five years later, they were exonerated when Flores admitted that she had lied. She did not see the defendants at the shooting; she identified them from pictures that disgraced police officer Raphael Perez showed her in a police book of gang members. They would probably never have been charged in the first place if the prosecution or the defense had known that Flores had carried on a romantic affair with Perez since she was 16.

In other cases, officers concealed evidence that would have undermined their own testimony about the facts of crimes they claimed to have witnessed. For example, in 1998 Jeffrey Santos was sentenced to six years in prison after a correctional captain testified that Santos punched him in the face at the Rikers Island jail in New York City. He was released three years later and eventually exonerated because the captain concealed the fact that he ordered a guard to punch him in the face hard enough to draw blood in order to create false evidence that he had been attacked by Santos, when in fact the captain and other guards had beat Santos without physical provocation.

\section{b. Substantive evidence of innocence}

As with impeachment, the range of concealed substantive evidence of innocence is huge, and-as with impeachment-several categories occur frequently:

\section{i. Forensic tests}

Some of the most disturbing cases of concealed exculpatory evidence involve hidden forensic tests. In some of the cases, it's hard to escape the conclusion that the officials who concealed the tests knew that the defendants were innocent but sent them to prison all the same.

You will recall that in the prosecution of Michael Morton for the murder of his wife, prosecutors not only concealed several items of powerful exculpatory evidence, but also resisted DNA testing on a discarded bandana that ultimately identified the real killer 24 years after Morton was sent to prison. In the murder prosecution of Kenneth Kagonyera, Robert Wilcoxson, Larry Williams, Jr., Damian Mills, and Teddy Isbell in North Carolina in 2001, pre-trial DNA testing was done on bandanas and gloves discarded by the criminals. The tests proved that none of the defendants participated in the crime-but the prosecution concealed that evidence.

DNA testing was not yet available when four teenagers-Omar Saunders, Larry Ollins, Calvin $\underline{\text { Ollins, }}$, and Marcellius Bradford-were charged with abduction, rape and murder in Chicago in 1988, but Pamela Fish, the forensic analyst who worked on the case, was able to determine the blood types of the rapists from semen that was recovered after the crime. Those tests also proved that the defendants were innocent; none of them had the same blood type as any of the rapists. That should have been the end of the case against them, but Fish concealed those results and then lied on the witness stand and said that semen found on the victim's body and undergarments could have come from three of the four defendants.

Not all concealed forensic evidence is equally powerful. At William Gregory's 1993 rape trial in Kentucky, a forensic analyst testified that several hairs found in a stocking cap left behind by the 
assailant shared "unusual characteristics" with Gregory's hairs, and were "more than likely" from Gregory. That testimony was shown to be false once DNA testing of hairs became available seven years later, but it reflected forensic knowledge at the time. On the other hand, the analyst also concealed the fact that several other hairs from same cap did not resemble Gregory's by any standard-evidence that did not establish his innocence, but would certainly have called the analyst's "match" into question.

Altogether, we know of 83 cases in which exculpatory forensic evidence was concealed, $6 \%$ of all exonerations $(83 / 1,361)$. In two-thirds of those cases the forensic evidence was concealed by prosecutors (55/83), in a quarter by the forensic analysts themselves (22/83), and in about $9 \%$ it was concealed by police $(8 / 83)$.

\section{ii. Alternative suspects}

Exculpatory information about suspects other than the wrongfully convicted defendants was concealed in $22 \%$ of exonerations with official misconduct (166/768), about $12 \%$ of all exonerations, more than any other type of concealed substantive exculpatory evidence.

In some cases, the concealed evidence described people other than the defendants who committed the crimes, or might have done so, but did not uniquely identify those suspects. By the time Anthony Gray pled guilty to murder in Maryland in 1991, for example, the authorities knew that an eyewitness said that a white man drove the victim's car away from the crime scene (Gray and his two codefendants were Black), that DNA tests on semen from the victim and fingerprints from the crime scene did not match any of the three defendants, and that a hair from the crime scene came from a white male. Gray and his attorneys knew none of this.

Similarly, after Douglas Dilosa, a white man, was convicted of murdering his wife in 1987 in Louisiana, his attorneys obtained a police report that had been concealed. It revealed that a witness saw two Black men leaving Dilosa's condominium complex on the morning of the murder; that at the time of the crime, police were investigating a similar break-in at a nearby condominium; that a hair found on the rope used to strangle his wife came from a Black person; and that unidentified fingerprints were found at the crime scene.

In other cases, the alternative suspect was identified by name but the authorities ignored and concealed that information. By the time Roy Brown was arrested for murder in 1991 in upstate New York, the police had collected statements from at least four witnesses describing suspicious behavior by the real killer, Barry Bench - but Brown only found out years later, after he had been convicted and sentenced to 25 years to life in prison. Brown was exonerated when Bench was identified by DNA testing in 2007. He would never have been convicted at all if the authorities had investigated Bench and obtained his DNA back in 1991.

And in some cases, prosecutors and police must have known exactly who committed the crime, but proceeded to convict an innocent defendant all the same. In 1991, Darrell Cameron was charged with a string of robberies in Chicago despite the fact that he was at least seven inches taller and 90 pounds heavier than the robber witnesses described. After he was convicted in one case, Cameron's defense lawyer interviewed a man who had been convicted of several similar robberies in the same area, and that man admitted that he had also committed the robberies that Cameron was charged with. Previously concealed documents in the prosecution file 
revealed that the real robber had already confessed to those robberies to an assistant state's attorney, months before Cameron was tried.

When evidence about alternative suspects was concealed, prosecutors were responsible twothirds of the time (111/165), more than twice as often as police officers. Police, of course, talk to many more witnesses than prosecutors and have many more opportunities to conceal exculpatory witness statements, on this or any other issue. If they do so, however, we are much less likely to ever know.

We usually learn about concealed witness statements because they were recorded or incorporated in a report. A police officer can hide a witness statement by simply doing nothingnever writing it up, recording it or telling anyone else. If so, it will probably never be discovered.

Prosecutors as well as defendants usually learn about witness statements from reports by police officers-which, as we've pointed out, are harder to conceal than unreported information. Once those statements are known to prosecutors, they-not the police-are responsible for any failure to disclose them to the defense.

Twenty percent of murder exonerations include concealed evidence of alternative suspects (123/608), compared to 6\% for all other exonerations (42/753). That probably reflects the fact that investigations for murder are bigger deals than for other crimes: the police are likely to talk to more witnesses, so there are more witness statements to conceal, and those statements are more likely to be written or recorded.

iii. "I don't see him" and "Not the guy"

In a smaller number of cases, authorities concealed evidence that the defendant did not commit the crime, without reference to who did.

In $2 \%$ of exonerations the defendants were not told that some eyewitnesses who saw the defendants in police identification procedures failed to identify them (28/1,361). For example, in 1977, Timothy Howard and Gary Lamar James were sentenced to death based entirely on testimony from eyewitnesses who identified them as the men who robbed a bank in Columbus, Ohio, and shot a security guard. They were exonerated in 2003 when their lawyers discovered that their convictions were based on egregious misconduct by a police detective who was later fired by the Columbus Police Department. Among other things, the detective suppressed the fact that three eyewitnesses - the two with best views of the criminals and a third who identified Howard in court-all failed to identify either defendant in a police lineup.

We suspect that this happens far more often than we know, including many cases in which there is no other misconduct. Police officers focus on finding evidence that identifies and convicts their suspects. Some don't seem to think of a failure to identify the suspect as "evidence" at all. But it is, of course, if the defendant is charged: evidence of innocence.

In about a quarter of these cases the witnesses went beyond failing to identify the defendant and specifically said that the defendant was not the perpetrator $(8 / 28)$. For example, in 2001, 11 years after Lathierial Boyd was convicted of shooting and killing a man outside a nightclub in Chicago, journalists located an eyewitness who was standing three feet away from the shooting. She said that after she failed to identify anyone in a lineup, she asked the detective to identify 
the suspect-and when he pointed to Boyd, she said there was "no way in the world" Boyd could be the gunman because he did not resemble the shooter. This statement was concealed; Boyd was exonerated in 2013.

\section{iv. Alibi evidence}

Only 19 cases, about $1 \%$ of the total, included concealed alibi evidence. This makes sense: a defendant with an alibi usually knows where she was and who witnessed her at that time and place. In several cases, however, authorities concealed evidence uniquely available to the police that would have confirmed alibis the defendants had already presented, and prevented the conviction of the innocent defendants.

When Daniel Taylor was charged with a double murder in Chicago in 1992, he knew where he was when the crime took place: in a Chicago police station lockup. He had a release slip with his signature and time-stamped after the murders to prove it. The prosecution claimed that the time on the slip was a mistake. Seventeen years after Taylor was convicted, concealed notes by the prosecutor described pre-trial interviews with seven police officers who confirmed that Taylor was still in the lockup at the time of the murders; two of them testified at Taylor's trial and said the opposite. If those interviews had been disclosed, neither Taylor nor his three innocent codefendants would have been convicted.

In two cases, the authorities suppressed video evidence of alibis. Kian Khatibi was convicted of a stabbing on a street in Pleasantville, New York, at 1:17 a.m. on January 11, 1998, because the Pleasantville police suppressed a videotape of Khatibi entering their police station 5 minutes earlier, at 1:12 a.m. And Claude McCullom was convicted of murder at the Lansing (Michigan) Community College in 2006 because the prosecution did not disclose a report by a Michigan State Police detective who analyzed security surveillance recordings and concluded that McCullom was in a different campus building at the time of the crime.

At Sean Ennis's trial, the concealed evidence did not concern the location of the defendant but the other element of an alibi defense: the time of the crime. Several years after his conviction for rape and kidnapping in Ohio in 1990, Ennis learned for the first time that the man who gave the victim a ride to the police station shortly after the crime told the police that the attack had occurred earlier than the victim said, at a time for which Ennis had a clear alibi.

v. No crime

In more than a third of known exonerations the defendant was not convicted of a crime that someone else committed, but of a crime that did not occur at all $(883 / 2,400)$. In about a sixth of those cases, $6 \%$ of all exonerations, the authorities concealed evidence that the crime the defendant was convicted of never happened. ${ }^{151}$

151 This estimate is based on data from two sources: 46 exonerations with concealed evidence that no crime occurred among the first 1,361 exonerations posted, or 3.4\%, plus the 66 Sergeant Watts group exoneration that all occurred after that set, or $2.8 \%$ of all 2,400 cases. See Methodological Appendix for additional details. 
In about $70 \%$ of exonerations with concealed evidence that no crime occurred, police planted drugs on innocent defendants (80/112). The great majority of those cases were the Sergeant Watts group exonerations in Chicago (66/80);152 the rest were similar, but not part of any known long-term pattern of planting evidence. In 1997, for example, members of the Manatee County (Florida) Sheriff's Department's anti-narcotics trafficking unit, broke in the door of Sarah Smith's apartment and arrested her for possession of crack cocaine they found in a bottle of Tylenol. At her trial, the deputy who arrested her concealed the fact that he had placed the crack in the bottle. He admitted it two years later after he was arrested in a federal investigation of corruption in that unit. ${ }^{153}$

In five murder trials prosecutors concealed evidence of the cause of death. Beverly Monroe, for example, might not have been convicted of the murder of her boyfriend in Virginia in 1992 if the prosecution had disclosed a medical report that concluded that the death was a suicide; and Eric Jackson-Knight might have been acquitted in Brooklyn in 1980 if the prosecutor had produced an expert report that concluded that the deadly fire he was accused of setting was accidental.

In a few rape exonerations, the authorities concealed evidence that the complainants had a history of making false rape accusations. And in at least a dozen child sex abuse cases, police, prosecutors and child welfare workers concealed statements by the supposed victims that they had not in fact been molested. For example, in 1982, Alvin McCuan, his wife Debbie McCuan, and their friends Scott and Brenda Kniffen were convicted on bizarre charges of sexually abusing the two couples' four children in Kern County, California. They might not have been if the jury had been told that the children had denied many times that any abuse had occurred.

In nine frame-up cases police officers were not merely witnesses against the exonerees, but claimed to be victims of assaults by those innocent defendants. Adam Tatum's case is probably the most outrageous. In 2012, he was attacked by Chattanooga (Tennessee) police officers at a re-entry facility for convicted felons, thrown to the ground and beaten so severely with fists and metal batons that his right leg was fractured in six places and he lost so much blood that hospital personnel thought he had been shot. Tatum was sentenced to two years in prison for assaulting the officers. A year later, he was exonerated when a previously concealed video showed that he was attacked without provocation.

152 See supra Section III.3.c.i. In one of these cases, the defendant was convicted of illegal possession of a planted gun rather than planted drugs.

153 In one additional drug crime exoneration, that of Jose Luis Pena, officers concealed evidence that plants they found in the defendant's care were not marijuana, but did not plant drugs on him. 


\section{Misconduet at Trial}

About 95\% of felony convictions in the United States-and an even higher proportion of misdemeanor convictions-are obtained by guilty pleas rather than trial verdicts. Exonerations are dramatically different: $80 \%$ of those in the Registry followed conviction at trial $(1,928 / 2,400)$. About $28 \%$ of those trials $-23 \%$ of all exonerations $(546 / 2,400)$-included official misconduct in court during the trial.

The most common form of official misconduct at trial was perjury by law enforcement officers, usually police officers. In addition, there were several distinct types of misconduct by prosecutors who violated rules that govern their conduct as officers of the court who represent the state in criminal proceedings.

\section{POLICE PERJURY}

Law enforcement officers are the most common witnesses called by prosecutors in criminal trials. Most of them no doubt tell the truth, but misconduct does occur. ${ }^{154}$ We know law enforcement officers committed perjury in $13 \%$ of all exonerations (304/2400), including in more than 14\% of exonerations after conviction at trial (284/1928). ${ }^{155}$ Eighty-four percent of cases with official perjury include perjury by police officers (256/304), about $18 \%$ include perjury by forensic examiners, and a handful include perjury by both. ${ }^{156}$

In Section VI we discussed one subgroup of cases with perjury by law enforcement officers: those in which officers "fabricated evidence" by writing false reports or testifying falsely to things they claimed to have seen or heard that powerfully incriminated the defendants. That

\footnotetext{
154 It may be-as many defendants and defense attorneys believe-that police are more likely to lie about the circumstances and legal justifications for stops, searches and arrests, than about evidence of guilt. Much, perhaps most of such testimony takes place at preliminary examinations and hearings on motions to suppress rather than at trial. In any event, this research focuses exclusively on misconduct that bears on evidence of guilt or innocence. We did not collect or analyze data on perjury in testimony that bears on the legality of searches and seizures.

155 In about $7 \%$ of the exonerations with known perjury by government officers, the convictions were based on guilty pleas (20/304); in those cases the perjury occurred at grand jury hearings, preliminary examinations or hearings on pre-trial motions.

156 In four cases we know of perjury by prosecutors; three of them also included perjury by police officers.
} 
category includes almost all known perjury by forensic examiners; ${ }^{157}$ cases in which police officers falsely testified that defendants had confessed when they had not; and cases in which officers planted drugs on innocent suspects, or falsely claimed that they had been assaulted. Each category includes cases in which the defendants pled guilty and spared the officers the need to commit perjury at trial.

In more than $90 \%$ of exonerations with police perjury the defendants were convicted at trial rather than by guilty plea (236/256). At $75 \%$ of those trials $(178 / 236)^{158}-7 \%$ of all exonerations-police officers lied about the conduct of the investigations or statements by other witnesses rather than about their own observations. Those are the cases we discuss in this section.

In some of the cases, police lied to make their own observations or conduct appear consistent with statements by other witnesses. For example:

At Steven Dewitt's murder trial in Washington D.C. in 1992, a police officer lied and said that an eyewitness told the police that the killer was driving a car with temporary license plates with the number sequence " 818 "-as was Dewitt when he was stopped. Ten years after Dewitt was convicted, defense attorneys discovered that the eyewitness had actually said the temporary plates included the numbers "829" and that police had stopped the real killer shortly after the crime-driving a car with temporary plates that ended with "829"-and let him go. Dewitt was exonerated in 2004.

Most police perjury, however, concerned the conduct of investigations.

At Christopher Roesser's murder trial in Georgia in 2008, a detective denied that a witness to the homicide ever told him that the deceased pointed a gun at Roesser and demanded his money. At a retrial in 2011, after Roesser's conviction was reversed, a medical examiner's investigator told the jury that the detective had told him exactly that. Roesser was acquitted.

At a pretrial hearing before James Walker's robbery-murder trial in Brooklyn in 1971, a detective testified that Walker had never been placed in a lineup. In fact, there had been a lineup at which the surviving victim of the robbery picked a police officer "filler" rather than Walker, but the jury did not know that when that

\footnotetext{
157 The exceptions we know about include a case in which the forensic examiner lied about his educational qualifications as an expert (LeFever), and one in which a medical doctor misrepresented the contents of the extensive medical records in the case (Eldridge).

158 This is an estimate. It's derived by totaling the number of trials of exonerees in which police officers lied about their own observation-trials of cases in which the officer planted drugs (or in one case, a gun) on the defendants (7 in the Sergeant Watts group and 12 others), plus those in which officers falsely claimed that the exonerees assaulted them (6), plus those in which police testified about fabricated confessions (33)-subtracting that total (58) from the number of all exonerations after convictions at trial in cases with perjury by police officers (236), and dividing the result by the total number of trials of exonerees with any police perjury (178/236).
} 
witness identified Walker at trial. Walker was exonerated 19 years later, after a pro-bono lawyer managed to uncover the true course of the investigation.

One common aspect of criminal investigations that police lied about was the conduct of interrogations at which innocent defendants confessed. For example:

Richard Danziger was convicted at a rape-murder trial in Texas in 1990 based on a confession by his codefendant, Christopher Ochoa. At Danziger's trial, the officers who obtained the confession testified that they took "great pains" not to tell Ochoa any of the facts of the crime, when in fact they had gone to great lengths to "correct" Ochoa's false confession to correspond to facts they already knew. Danziger and Ochoa were both exonerated by DNA in 2002.

When William Oakes was convicted of murder in New York in 1985, the two detectives who took his confession testified that they did not abuse him in any manner. After he was convicted, however, two fellow detectives gave sworn statements that those officers told them that during a "night of terror" that "scared the hell out of Oakes" they beat Oakes, fired a gun three times near his ear, pointed it at him and threatened to pull the trigger. Oakes was exonerated in 1992.

As we have pointed out, we undercount misconduct of all sorts because it's usually hidden and often never comes to light, even if an innocent defendant is exonerated. That general problem is even worse for police perjury because of the limitations of our data.

We rarely have access to transcripts of the trials at which exonerees were falsely convicted. In most cases, we rely on other legal documents-motions, briefs, opinions-and on news reports. In many cases it is clear that the jury was misled by false evidence, but we don't know which police officers testified, or if they did, what they talked about.

We are most likely to be able to identify police perjury if defendants (or their lawyers) raised it as a legal claim, or if we know that an officer testified in a manner that is plainly inconsistent with facts that are now known. Otherwise, we rarely know.

\section{TRIAL MISCONDUCT BY PROSECUTORS}

\section{a. Permitting Perjury}

A lawyer may not knowingly use false evidence in court. That prohibition has two parts. First, it's misconduct for a lawyer to "offer evidence [in court] that the lawyer knows to be false." 159 Second, "if a witness called by the lawyer has offered material evidence and the lawyer comes to know of its falsity, the lawyer [must] take reasonable remedial measures...." 160

\footnotetext{
${ }^{159}$ Am. Bar Ass'n, Model Rules of Prof'l Conduct, Rule.3.3(a)(3). Note that there is a possible exception for testimony by a criminal defendant.

160 ld.
} 
If the lawyer is a prosecutor in a criminal case, the "remedial measures" in response to unanticipated lies by a witness must include disclosing the perjury to the court. That follows from the prosecutor's professional and constitutional obligation to disclose exculpatory evidence-in this context, the fact that a prosecution witness has just lied-but it's also an older constitutional rule that the Supreme Court built on when it defined the duty to disclose exculpatory evidence in Brady $v$. Maryland in $1963 .{ }^{161}$

In 1959, the Supreme Court held in Napue v. Illinois ${ }^{162}$ that "a conviction obtained through use of false evidence, known to be such by representatives of the State, must fall under [the due process clause of] the Fourteenth Amendment," that this "result obtains when the State, although not soliciting false evidence, allows it to go uncorrected when it appears," and that "[i]t is of no consequence that the falsehood bore upon the witness' credibility, rather than directly upon defendant's guilt."163 In short, under Napue, a prosecutor has a constitutional obligation to correct perjury by a state witness even if she did not herself offer the false testimony.

We know that prosecutors permitted perjury to go uncorrected in $8 \%$ of exonerations $(186 / 2,400)$. In almost all of these cases, by definition, the prosecution also concealed exculpatory evidence. ${ }^{164}$ For example, when a forensic analyst falsely testified at Ulysses Charles's rape trial that he found no seminal fluid on a vaginal swab of one from the victims, the prosecutor knew that the analyst had in fact found seminal fluid on the swab that could not have come from Charles, but did nothing to disclose that exonerating evidence or correct the perjury. ${ }^{165}$

Sometimes the perjury is related to other categories of misconduct. In a minority of cases, the prosecutors themselves procured the perjury, presented it in court, and then, of course, did nothing to correct it. In others, prosecutors failed to correct perjury by police or other law enforcement officers. For example:

In June 2003, Abdel-Ila Elmardoudi, Karim Koubriti, and Ahmed Hannan were convicted of supporting terrorism and related charges in federal district court in Detroit, Michigan, for allegedly planning bomb attacks on targets around the world. The prosecution focused heavily on drawings by the defendants that allegedly depicted one such "target"-a hospital in Jordan. In fact, the prosecutor knew that the drawings were among a set of harmless sketches of the entire region, and the prosecutor concealed actual photographs of the hospital taken by a State Department investigator.

\footnotetext{
161 Brady v. Maryland, 373 U.S. 83 (1963).

162 Napue v. Illinois, 360 U.S. 264 (1959).

163 Id. at 269.

164 In a handful of cases, it appears that the perjury by the state witness in question was or should have been known to the defense.

165 See supra Section VI.4.a.
}

Government Misconduct and Convicting the Innocent The Role of Prosecutors, Police and Other Law Enforcement 
When the investigator lied under oath and said he had no comparison photographs of the hospital, the prosecutor let the perjury stand. All three defendants were exonerated in 2004. In 2006, the prosecutor and the investigator were indicted for obstruction of justice; they were later acquitted.

In most cases, however, the perjury was by civilian witnesses. The most common issue they lied about is the one the Supreme Court addressed in Napue: the fact that they had received benefits from the state in return for testifying-usually favorable treatment in pending criminal cases of their own. ${ }^{166}$ For example:

At Jabbar Collins's murder trial in Brooklyn in 1994, three witnesses lied and said that they made no deals with the prosecution in return for testifying against Collins. The prosecutor not only failed to correct the record, but ridiculed the claim that such deals had been made in his argument to the jury. In 2010, a federal judge compelled the prosecution to produce withheld documents that described how the prosecution had threatened and manipulated the witnesses, and eventually struck deals with them. After the court vacated the conviction, the District Attorney's office agreed to dismiss the charges but reiterated its "position, then and now... that we believe in this defendant's guilt." The judge responded: "It's really sad that the D.A.'s office persists in ... saying they did nothing wrong here.”

Lying about deals with the prosecution may be a common form of perjury by government witnesses, but that is not the only reason we see it so frequently in cases in which prosecutors have permitted perjury to stand uncorrected. In that context, the prosecutor's knowledge of the perjury by a witness is unusually easy to detect.

We only list a case as including this sort of misconduct if there is specific evidence-statements or documents-that the prosecutor knew the testimony was false. If a witness lies about other issues, we are unlikely to have enough information to conclude that the prosecutor was aware of the perjury; but prosecutors will always know about deals with witnesses that they or their offices entered into.

\section{b. Lying in Court}

In 1997, in Hampton County, Virginia, Ricky Cullipher was convicted of shooting a friend who was left brain-damaged and in a coma. Cullipher's attorney, George L. Smith, asked for a delay because an eyewitness failed to appear in court, but the trial proceeded after the prosecutor told the court that the witness had

166 Napue, 360 U.S. at 270. 
nothing to add to the testimony of other witnesses. In fact-as the prosecutor knew-the missing eyewitness would have testified that the victim shot himself. ${ }^{167}$

In 2009, Timothy Parkes was convicted of bank fraud in federal court in Tennessee. In his closing argument, the prosecutor told the jury that if Parkes were acquitted, he'd get to "keep the $\$ 4$ million" that his company had at one point owed the bank in question. This was false; by then most of the money had been repaid. The jury would have known that if the same prosecutor had not persuaded the trial judge to prevent Parkes' lawyer from presenting evidence that the debt had been paid off.

In both of these cases, prosecutors lied about important facts in trials at which they represented the government. They weren't speaking under oath, so they did not commit perjury, but lawyers are prohibited from lying in court under any circumstances. Rule 3.3 of the American Bar Association's (ABA) Model Rules of Professional Conduct, for example, provides that "A lawyer shall not knowingly... make a false statement of fact or law to a tribunal or fail to correct a false statement of material fact or law previously made to the tribunal by the lawyer." 168 Violating this duty can subject a lawyer to punishment for contempt of court, even if not under oath. ${ }^{169}$

This rule applies to prosecutors with special force. Standard 3-1.4 of the ABA's Standards for the Prosecution Function states that "the prosecutor has a heightened duty of candor to the courts." 170 Courts agree that they are "entitled to a higher degree of candor and professional responsibility from government counsel," 171 and should be able "to rely on the prosecutors' open court, on the record representations, without the need of a formal oath." ${ }^{172}$

In practice, punishing prosecutors for lying is rare. In 2007, Mike Nifong-the District Attorney of Durham County, North Carolina, who handled a notorious rape prosecution of several members of the Duke University lacrosse team-was held in contempt and sent to jail for one day for lying in court in that case. ${ }^{173}$ And in 2013, Ken Anderson, who as District Attorney of Williamson County, Texas, sent Michael Morton to prison for 25 years for a murder he did not commit, was sentenced to 10 days in jail because he lied to a judge in 1987 when he said that he

\footnotetext{
167 It's worth noting that Cullipher's defense attorney provided a constitutionally inadequate defense: he had not read the police reports and did not know that the prosecutor was lying. In fact, it was the defense counsel's ineffective legal assistance rather than the prosecutor's misconduct that was the basis for the reversal of Cullipher's conviction.

168 Am. Bar Ass'n, Model Rules of Prof'l Conduct, Rule.3.3(a)(1).

169 E.g., In re Aguilar, 97 P.3d 815, 820 (Cal. 2004) ("It is, of course, an extremely serious breach of an attorney's duty to a court to lie in statements made to the court, and an intentionally false statement made by an attorney to a court clearly constitutes a contempt of court.") (Internal citations omitted.)

170 Criminal Justice Standards for the Prosecution Function § 3-1.4 (Am. Bar Ass'n 2017).

171 Miller v. Lehman, 603 F. Supp. 164, 166-67 n.3 (D.D.C. 1985).

172 People v. Hameed, 666 N.E.2d 1339, 1342 (N.Y. 1996).

173 Sahila Dewan, Duke Prosecutor Jailed; Students Seek Settlement, N.Y. Times, Sept. 8, 2007.
} 
had disclosed all the evidence in his possession that tended to show that Morton was innocent. ${ }^{174}$ (Anderson actually served only four days.) As far as we know, these are the only two American prosecutors who have ever been convicted of criminal contempt for lying in court, although a few others may have been disbarred, as Nifong and Anderson were.

On the other hand, lying in court by prosecutors is reasonably common in cases in which defendants were later exonerated. We know it occurred in $4 \%$ of exonerations $(94 / 2,400)$, but the real rate is probably considerably higher because we only classify a statement as a lie if we have a clear indication that the prosecutor knew it was false.

About half of courtroom lies by prosecutors occurred in closing argument. This is not surprising: closing argument is the context in which lawyers are permitted to discuss the case most freely.

Needless to say, closing arguments are not supposed to be occasions for lawyers to lie or make up facts. Advocates are allowed to try to persuade the jury to accept their versions of the events on trial-that's the main purpose of argument-but they are limited to discussing evidence that was presented in court. Lawyers are allowed to draw inferences from the evidence in closing argument, and to try to persuade the jury to accept those inferences-for example, that a witness whose testimony is disputed is telling the truth. But all lawyers-and especially prosecutors in criminal trials-are prohibited from making such arguments based on factual assertions they know to be false.

A common lie of this sort concerns deals between prosecutors and witnesses:

At Yancey Douglas and Paris Powell's separate trials, in 1995 and 1997 respectively, for a drive-by murder in Oklahoma City, the surviving witness to the shooting identified them as the shooters-and testified that he had received no favors from the prosecution for testifying. In his closing argument, the prosecutor repeated the claim that the victim had received no benefits for testifying. Powell and Douglas were both sentenced to death. In 2009, all charges were dismissed after the victim recanted and said that he had been drunk and high on the night of the shooting and was unable to identify the shooters, but that he agreed to name them in return for a deal with the prosecutor for a reduced sentence on drug trafficking charges that he himself faced.

In other trials of exonerated defendants, Timothy Parkes's for example, ${ }^{175}$ the prosecutor lied in closing argument by making factual claims that had no basis in any evidence in the record. And in Michael Tillman's murder trial in Chicago in 1986, the prosecutor told the judge who tried the case without a jury that a pubic hair from Tillman had been found at the crime scene. In fact, as the prosecutor knew, the only witness who testified on the issue-a crime analyst-had only said the hair was "similar" to Tillman's hair.

\footnotetext{
174 Molly Hennessy-Fiske, Ex-Prosecutor Punished For Withholding Evidence in Murder Case, L.A. Times, Nov. 8, 2013.

175 See supra Section VIII.2.b.
} 
When prosecutors lied in court outside of closing argument, they usually did it in proceedings on procedural issues. In some trials they then went on to repeat the lies in closing argument.

At Daniel Villegas's murder trial in El Paso, Texas in 1995, his defense attorney agreed to stipulate to the prosecutor's description of the autopsy report, including a statement that the victim had been shot three times. In fact, the autopsy had found only two bullet wounds, as the prosecutor well knew: he had said so himself at an earlier trial that ended with a hung jury. In his closing argument, the prosecutor used this misinformation to argue that because Villegas had shot the victim three times, he must have intended to kill him.

In many of these cases, defense lawyers could have prevented or corrected the prosecutors' misrepresentations. Michael Tillman's and Daniel Villegas's lawyers both had access to the forensic reports that the prosecutor misrepresented at their trials, but let the lies stand. Ricky Cullipher's lawyer, as we noted, was no better. ${ }^{176}$ That is a separate and equally important form of misconduct by the lawyers who represented the exonerees. Taking advantage of the incompetence or indifference of defense attorneys is no justification for government misconduct.

\section{c. Improper Statements in Closing Argument or Cross-examination}

So far, the misconduct at trial that we've discussed concerns lies-lies by police, lies by state witnesses that prosecutors fail to correct, lies by prosecutors themselves. But prosecutors may also commit misconduct in court proceedings without lying, typically in statements in closing arguments or questions on cross-examination.

Many rules restrict what lawyers can say in argument and cross-examination. Some are firm and some are discretionary; some are clear and specific, others general and vague. Violations of these rules-clear or ambiguous-are common.

In general, we consider these to be less severe forms of misconduct than the others we have discussed-in part because the most serious subcategory, improper argument that includes deliberate deception by the prosecutor, is discussed in the previous section on lying in court rather than here. ${ }^{177}$

Unlike lying or permitting perjury, these misdeeds do not involve concealing information from the defense. As a result, they can (at least in theory) be brought to the attention of the judge and addressed on the spot-if the defense attorney is prepared and vigilant (which is often not the case), and lodges an objection on the spot. Otherwise, any objection will generally be considered

\footnotetext{
176 See supra Section VIII.2.b.

177 Strictly speaking, a question to a witness-even a strongly worded leading question on cross-examination, such as "You've killed several people, haven't you?"-is not a statement that can be deceptive but an inquiry that is negated if the witness answers "No." Such a question obviously implies that the witness killed people, and may well be improper, but even if the implication is false, it is not, literally, a lie.
} 
to have been "waived"-which happens frequently because the lawyer is inattentive, unskilled or unprepared.

There are also strong reasons for competent, attentive lawyers to forgo objections.

Claims of improper cross-examination or argument rarely succeed on appeal. If the defendant did not object at trial, she is usually not allowed to raise the issue at all; if she did object and the trial judge sustained the objection and told the jury to disregard the statement, an appellate court will typically say that any problem was corrected by the lower court; and if the trial judge overruled the objection, a higher court will generally agree with that outcome, or find that if the trial judge "erred" the error was "harmless" and does not require reversing the judgment.

There is little incentive to make an objection that is likely to be ignored, and it may draw attention to a statement that would otherwise go unnoticed, or suggest that the defendant has something to hide.

In addition, this sort of misconduct occurs in open court, an arena-unlike criminal investigation-in which the state and the defense operate on roughly equal terms. Defense attorneys as well as prosecutors often tread close to or cross the foul lines in court. Many trial lawyers fail to object to arguably improper questions and arguments by their opponents in order to discourage the opposition from objecting to their own questions and arguments, and the judge from granting objections that are made.

For all these reasons, defense attorneys frequently fail to object to misconduct in argument or cross-examinations-and without an objection, we will rarely know that this sort of misconduct occurred.

We only know about impermissible arguments and cross-examinations if they become the subjects of significant disputes, typically on review after conviction. They occurred in about 4\% of exonerations (93/2,400), mostly, 3\%, in closing argument $(77 / 2,400)$, although $1 \%$ of cases included impermissible cross-examination $(26 / 2,400)$ and about half a percent had both (10/2,400).

Closing argument and cross-examination are two contexts in which an attorney can talk about the facts of the case in her own voice. In both, the ABA Standards for Criminal Justice provide that a "prosecutor should not bring to the attention of the trier of fact matters that the prosecutor knows to be inadmissible, whether by... asking legally objectionable questions, or making impermissible comments or arguments." 178

For argument, the nature of the problem is obvious. The main purpose of closing argument is to permit the lawyer for a party to make her case to the jury-or the judge in a non-jury trial-by persuasively organizing and summing up the evidence that supports her client's position. That creates an opportunity to tell the jury things that are false, unsupported by evidence, misleading

${ }^{178}$ Criminal Justice Standards for the Prosecution Function § 3-6.6 (Am. Bar Ass'n 2017). 
or inflammatory. More often than not, such transgressions are overlooked-but they can do serious damage in the context of a particular case.

In 1993, Kathryn Wilson was convicted on five felony counts of child sex abuse in a notorious prosecution for satanic ritual child sex abuse at the Little Rascals daycare center in Edenton, North Carolina. She was sentenced to life imprisonment.

Two years later, the North Carolina Court of Appeals reversed the conviction for prosecutorial misconduct, including "grossly improper" closing argument. During the trial, the prosecutor was prohibited from impeaching Wilson's credibility by calling witnesses to testify to an alleged theft for which she was never charged, let alone convicted. Such witnesses are generally excluded in American trials because their evidence is considered insufficiently reliable and overly prejudicial to the defendant. The prosecutor responded by telling the jury in closing argument that he had witnesses in court ready to testify to "the truth"-that Wilson had committed the theft-but "could not put those people on the witness stand" to do so.

The Court of Appeals held that "This was a grossly improper argument... [T] prosecution accomplished during its closing argument precisely what it could not during the trial." The court went on to reverse the conviction because the supposed victims, who had been heavily coached, "testified to events occurring approximately three years before trial when they were only three or four years old.... [T] here were no witnesses to the alleged abuse, and scant physical evidence.....Defendant testified on her own behalf and denied all of the allegation. ... [Her] credibility was critical to her defense." 179

The prosecutor at Wilson's trial made factual claims that had no basis in the evidence presented in court. That's a common type of improper closing argument that we see in trials of exonerated defendants. In Wilson's case, the misconduct was aggravated because the evidence the prosecutor described in argument had been specifically excluded from consideration.

Other types of improper argument include:

- Statements that the prosecutor "knows" or is "certain" that the defendant is guilty, which are prohibited by the general rule that at trial "A lawyer shall not... state a personal opinion as to the justness of a cause... or the guilt or innocence of an accused."180

179 State v. Wilson, 456 S.E.2d 870, 874-875 (1995).

${ }^{180}$ Am. Bar Ass'n, Model Rules of Prof'l Conduct, $\underline{\text { Rule.3.4. }}$ 
- Arguments that a defendant who did not testify or talk to the police must be guilty or she would have said otherwise, which violate the defendant's Fifth Amendment right to remain silent. ${ }^{181}$

- Appeals to racism, sexism or homophobia.

- Inflammatory arguments: the defendant is a monster who must be stopped; God, or justice for the dead victim, or protection of the community, requires a conviction. Marcella and Ricky Pitts's child sex abuse convictions, for example, were reversed in part because the appellate court found that the prosecutor had essentially told the jury that Christ was a witness for the prosecution. ${ }^{182}$

Cross-examination also permits a lawyer to speak directly to the judge and jury in a different manner than in closing argument. Unlike direct examination, lawyers may use leading questions freely in cross-examination of a witness called by the opposing party. That means they can articulate the testimony in the questions they ask, with the witness limited to agreeing or disagreeing. For example:

Q: When you first entered the conference room, there was only one other person there, right? A: Yes.

Q. And that was your boss, Sheila Brooks? A: Correct.

Q: And she told you, didn't she, while you were still alone, 'Don't say anything unless I ask you a question'? A: Right

On direct examination, the lawyer might have been limited to "Was anybody in the conference room when you entered?" and "What, if anything, did she say to you?"

The structure of cross-examination makes it possible for a prosecutor to phrase an assertion as a question-"You embezzled more than $\$ 100,000$ from your employer, didn't you?" - and create the impression that the defendant did something bad or incriminating even if the defendant, predictably, denies it. That practice is frowned upon; in some cases, it amounts to serious misconduct.

At Charles McClaugherty's 2001 murder trial in Albuquerque, New Mexico, the prosecutor asked him on cross-examination: "Sir, would it surprise you to hear that your sister, Sarah Tucker, gave a statement to the police 6/19/99 ... that said that you admitted to her that you shot a gun?" The defendant answered that it would surprise him. The prosecutor then asked a question about a similar statement McClaugherty supposedly made to his roommate, Sherri Goen, and got the same answer.

\footnotetext{
181 Miranda v. Arizona, 384 U.S. 436 (1966); Griffin v. California, 380 U.S. 609 (1965).

182 People v. Pitts, 223 Cal. App. 3d 606, 701 (1990).
} 
In 2003, the New Mexico Supreme Court vacated McClaugherty's conviction and ordered a new trial because "Defendant had no chance to prove that he never made the statements to which the prosecutor referred during cross-examination. Without such an opportunity, the jury was left to assume that Defendant actually admitted that he shot a gun that night." 183

Charges against McClaugherty were later dismissed because the misconduct was found to be willful, in part because "[t]he actual police interviews conducted on June 19, 1999, do not contain statements from either Tucker or Goen that Defendant confessed that he shot and then bragged about it." 184

183 State v. McClaugherty, 133 N.M. 459, 468 (2003).

184 State v. McClaugherty, 144 N.M. 483, 494 (2008). 


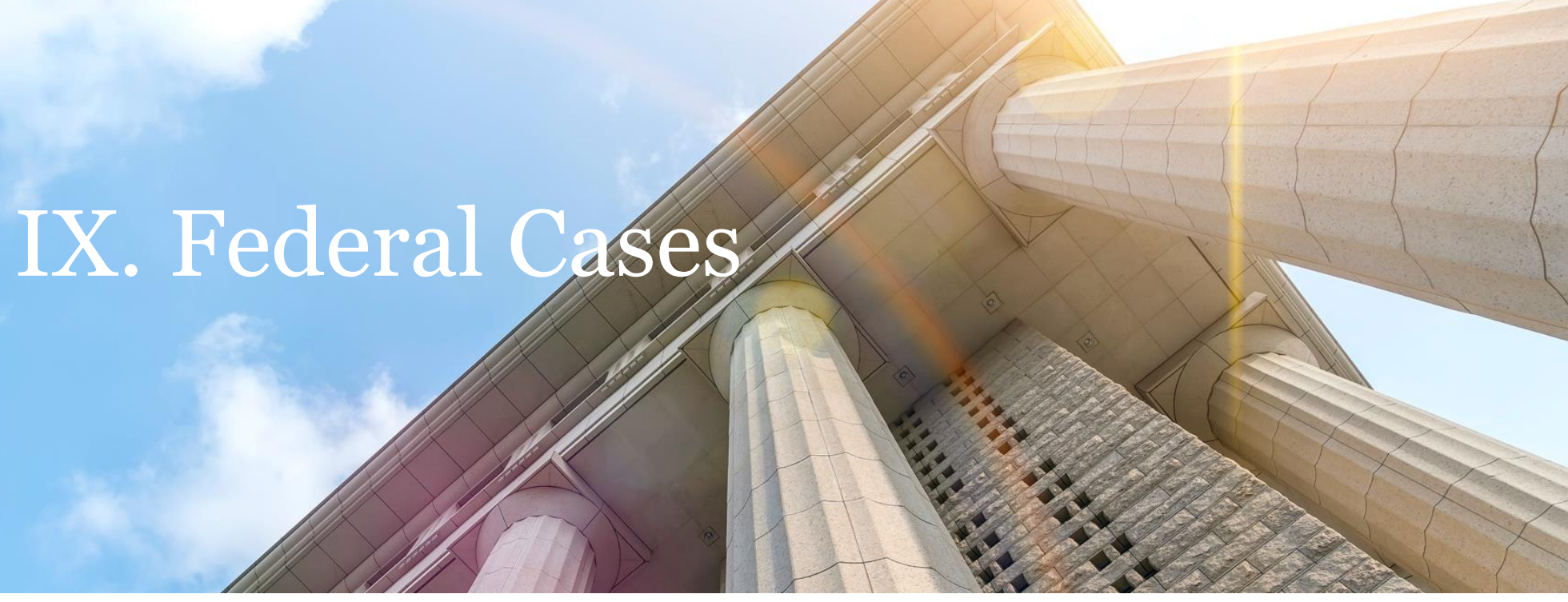

Federal cases are a small minority of all criminal prosecutions in the United States. In 2006, for example, only $6 \%$ of felony convictions in the United States were in federal court, ${ }^{185}$ and only $14 \%$ of prison inmates were in federal prisons. ${ }^{186}$ Federal convictions are also systematically different from state convictions. Eighteen percent of felony convictions in state courts in 2006 were for violent crimes, ${ }^{187}$ and $54 \%$ of inmates in state prisons were convicted of such crimes $^{188}$-but fewer than $4 \%$ of federal convictions were for crimes of violence, ${ }^{189}$ and only $9 \%$ of federal prisoners were serving time for violent felonies. ${ }^{190}$

Five percent of exonerations in the United States are from convictions for federal crimes $(112 / 2,400)$. Exonerations in federal cases are no more representative of all federal convictions than state-court exonerations are of state convictions. Violent crimes are overrepresented among federal exonerations, $28 \%(31 / 112)$ versus about $4 \%$ of convictions, but they're still a minority compared to more than $80 \%$ of state-court exonerations. Drug crimes are underrepresented but only slightly, $22 \%$ of exonerations (25/112) and $36 \%$ of convictions, while immigration and weapons crimes are greatly underrepresented-about $4 \%$ of exonerations each, compared to $23 \%$ and $12 \%$ of convictions, respectively. On the other hand, white-collar crimes account for $16 \%$ of federal convictions, ${ }^{191}$ but $41 \%$ of federal exonerations. See Table 20.

185 See Bureau of Justice Statistics, Federal Justice Statistics 2006 Table 4.2 (2006) (hereinafter BJS, Federal Justice Statistics 2006); see also Bureau of Justice Statistics, Felony Sentences in State Courts, 2006 Table 1.1 (Dec. 2009) (hereinafter BJS, Felony Sentences in State Courts, 2006) (dividing 73,804 by 1,206,094).

186 Bureau of Justice Statistics, Prisoners in 2006, Table 1 (Dec. 2007).

187 See BJS, Felony Sentences in State Courts, 2006, supra note 185, at Table 1.1.

188 Id. at Table 11.

189 See BJS, Federal Justice Statistics 2006, supra note 185, at Table 4.2.

190 Id. at Table 12.

191 "White-collar" exonerations include those for convictions for bribery, false report, forgery, fraud, obstruction of justice, perjury, supporting terrorism, and tax evasion. "White-collar" crimes for federal convictions in 2006 include convictions for Property offenses classified as "Fraudulent" and Regulatory offenses classified as "Public Order," 
Table 20: Proportions of all Federal Exonerations, and of Federal Convictions in 2006, by Crime

\begin{tabular}{lc|c} 
& $\begin{array}{c}\text { Exonerations } \\
(112)\end{array}$ & $\begin{array}{c}\text { Convictions } \\
(73,804)^{192}\end{array}$ \\
\hline White-collar (46) & $41 \%$ & $16 \%$ \\
\hline Violence (31) & $28 \%$ & $4 \%$ \\
\hline Drugs (25) & $22 \%$ & $36 \%$ \\
\hline Immigration (4) & $4 \%$ & $23 \%$ \\
\hline Weapons (5) & $4 \%$ & $12 \%$ \\
\hline Military Justice (1) & $1 \%$ & - \\
\hline $\begin{array}{l}\text { Other Property \& } \\
\text { Public Order Crimes }\end{array}$ & - & $9 \%$ \\
\hline
\end{tabular}

The rate of official misconduct is somewhat higher among exonerations in federal cases than in state cases, $61 \%$ compared to $54 \%$. There is a much larger difference, however, between the rates of misconduct in state and federal exonerations by prosecutors and by police officers. In state cases, police officers are more likely to commit misconduct than prosecutors by a modest amount, $36 \%(821 / 2,288)$ to $29 \%(671 / 2,288)$. In federal cases prosecutors commit misconduct much more often than police, $52 \%(58 / 112)$ to $20 \%$ (22/112). All three rates-overall misconduct, misconduct by prosecutors and misconduct by police-vary considerably among the three categories of crimes that account for 91\% of federal exonerations. See Table 21.

"Tax," "Bribery," "Perjury, Contempt \& Intimidation," "National Defense" and "Environmental." See BJS, Federal Justice Statistics 2006, supra note 185, at Table 4.2.

192 Id. 
Table 21: Official Misconduct by Prosecutors and by Police in Federal Exonerations, by Crime* $^{*}$

\begin{tabular}{|lcc|c|} 
& $\begin{array}{c}\text { Misconduct by } \\
\text { Prosecutors }\end{array}$ & $\begin{array}{c}\text { Misconduct } \\
\text { by Police }\end{array}$ & $\begin{array}{c}\text { ALL OFFICIAL } \\
\text { MISCONDUCT }\end{array}$ \\
\hline White-collar (46) & $65 \%$ & $9 \%$ & $65 \%$ \\
\hline Violent (31) & $45 \%$ & $39 \%$ & $61 \%$ \\
\hline Drugs (25) & $36 \%$ & $20 \%$ & $48 \%$ \\
\hline $\begin{array}{l}\text { ALL FEDERAL } \\
\text { EXONERATIONS (112) }\end{array}$ & $52 \%$ & $20 \%$ & $61 \%$ \\
\hline
\end{tabular}

* Some cases include misconduct by more than one type of official.

As we see in Tables 19 and 20 together, the distinctive patterns in federal exonerations overlap: the largest concentration of federal exonerations is among white-collar crimes; the overwhelming majority of misconduct is by prosecutors rather than police; and that skewed pattern of misconduct-prosecutors rather than police-is strongest among white-collar cases.

\section{WHITE-COLLAR CRIMES}

In some respects, white-collar exonerations are to federal courts what murder exonerations are to state courts: They're the most common type of federal exonerations, 41\% (compared to 40\% for state murder exonerations); they're overrepresented compared to the rate of convictions (although by a smaller margin than murder cases among state court exonerations); and they have a high rate of official misconduct, $65 \%$ compared to $72 \%$ for state-court murders.

There are major differences, of course-especially from the point of view of the exonerees. Those convicted of federal white-collar crimes received far lighter sentences than those convicted of murder, ${ }^{193}$ and they were exonerated much more quickly. The median time from conviction to exoneration was 14 years for murder cases but only three years for federal white-collar crime exonerations.

On the other hand, from the point of view of the prosecutors, there are important similarities between these two sets of cases. Judging from exonerations, white-collar cases in federal courtlike murder cases in state court-are more likely than any others to be big-ticket prosecutions: expensive, long-running, conspicuous. That suggests that, like murder cases in state court, ${ }^{194}$

\footnotetext{
193 Thirteen percent of murder exonerees were sentenced to death (121/908) and 43\% were sentenced to life imprisonment (391/908); $2 \%$ were not sentenced before exonerations (14/908); and the remaining $42 \%$ received prison sentences averaging 34 years. Among Federal white-collar exonerations, $11 \%$ received probation, $41 \%$ were not sentenced, and $48 \%$ were sentenced to prison terms averaging 2.6 years.

194 See supra, Section III.3.a.
} 
they are unusually likely both to include official misconduct, and, for misconduct that occurs, to be discovered. For example:

In July 2008, United States Senator Ted Stevens of Alaska was indicted in Washington, D.C., for failing to report gifts totaling about $\$ 250,000$, allegedly the costs of renovations of his home that were paid by the VECO Corporation, an oil pipeline service and construction company. Stevens, who was running for reelection, demanded an immediate trial. He was convicted on October 27, 2008, and lost the election eight days later.

Five months later, the charges against Stevens were dismissed at the request of the Department of Justice. In between, a whistleblower affidavit from an FBI agent led to the discovery of a raft of government misconduct and concealed evidence, including:

- A female FBI agent had an inappropriate relationship with the central witness against Stevens-Bill Allen, the former CEO of VECO, who had pled guilty to bribing several Alaskan state legislators and whose sentencing was deferred until after he testified against Stevens. Allen had also done favors for other FBI agents.

- Allen had told the government that the fair market value of the improvements on Steven's property was about $\$ 80,000-$ not the $\$ 250,000$ that he testified to at trial-and that Stevens probably would have paid for them if asked.

- Another witness who was involved in the renovations told prosecutors that he had told the senator that the bills Stevens received-and promptly paid-included all of the work that was done. In response, they sent him back to Alaska and concealed his existence.

In November 2011, an independent investigation ordered by the judge concluded that federal prosecutors in the Stevens case engaged in "significant, widespread and, at times, intentional misconduct." By then, one of those prosecutors had hanged himself.

The Stevens case is extreme, disturbing and tragic. The judge who dismissed the charges said "In nearly 25 years on the bench, I've never seen anything approaching the mishandling and misconduct that I've seen in this case," and he cited several prosecutors for criminal contempt. But less notorious cases have disturbing similarities.

In 2014, Reddy Annappareddy was convicted on charges that he bilked Medicaid, Medicare, and private insurers out of millions of dollars by submitting fraudulent billings for prescriptions filled by pharmacies he owned in Maryland and Washington, D.C. In 2017, the trial judge dismissed the charges and said that the failure to disclose exculpatory evidence and "the history of late disclosures and 
the promotion of false significant testimony in this case does shock the conscience of this Court."

Among other things, the prosecution had concealed an audit that indicated that alleged losses were far smaller than the government claimed (a thorough accounting eventually found none at all); and the FBI had repackaged expired drugs from a clinic that the defendant's company was holding for destruction, and claimed in court that the pharmacies had obtained those drugs using fraudulent prescriptions and never delivered them to patients.

\section{MISCONDUCT BY PROSECUTORS}

As we have noted, state-court exonerations include more misconduct by police than by prosecutors. Even among murder exonerations, where the overall rate of official misconduct is comparable to federal white-collar cases, misconduct by police is slightly more common than misconduct by prosecutors, $48 \%$ to $44 \%$. In federal cases generally, prosecutors commit misconduct more than two-and-a-half times as often as police officers. This disproportion is greatest among white-collar exonerations, where federal prosecutors committed misconduct seven times as often as police. In fact, every single federal white-collar exoneration with official misconduct includes misconduct by a prosecutor.

This striking pattern no doubt reflects the structure of white-collar prosecutions, at least in federal court. ${ }^{195}$ Judging from exonerations, they are overwhelmingly the products of lengthy proactive investigations. Nearly 60\% are multi-defendant exonerations (26/46), and, although in general federal prosecutors often work with state and local police, at least two-thirds of these cases included federal law enforcement agencies (30/46). It appears that federal prosecutors were deeply involved in the investigations that led to these white-collar prosecutions, and probably initiated many of them. By contrast, state prosecutors usually first hear about a violent crime-even a murder-when police ask them to charge a defendant who has already been identified, arrested, and, frequently, interrogated.

That level of prosecutorial control over criminal investigations means that federal prosecutors are more likely to know what the police know, and to play a role in any official misconduct that occurs-especially if the misconduct is concealing exculpatory evidence.

As we've noted, the primary duty to disclose exculpatory evidence falls on prosecutors. ${ }^{196}$ If police tell prosecutors about such evidence, they've done all they're required to do. Therefore, we only count the police as responsible for concealing evidence if there is no indication that prosecutors knew about the evidence in question. Even so, police officers were responsible for concealing exculpatory evidence in $46 \%$ of state murder exonerations where such evidence was hidden (165/355), compared to $65 \%$ for prosecutors (230/355). But among the federal whitecollar cases in the first 1,361 exonerations posted in the Registry, prosecutors were responsible

\footnotetext{
195 Seventeen white-collar exonerations were in state courts, $27 \%$ of the total. Of these, $53 \%$ included official misconduct (9/17) $-35 \%$ misconduct by prosecutors $(6 / 17)$ and $18 \%$ by police $(3 / 17)$.

196 See supra Section VI.3
} 
for withholding exculpatory evidence in every single case in which such evidence was concealed (12/12), and police in none.

On the other hand, witness tampering is a form of misconduct that's overwhelmingly committed by police officers. ${ }^{197}$ It occurred in $32 \%$ of all state murder exonerations (286/904), and 88\% of those cases included misconduct by police (252/286). Witness tampering only occurred in $17 \%$ of federal white-collar exonerations (8/46), and in every case it was done by prosecutors; we know of no police misconduct in any of those cases.

Some of these discrepancies may in part reflect differences in record keeping and in the structure of the cases. Federal prosecutors may keep more complete records than state prosecutors because they have more resources at their disposal, or are subject to more demanding departmental rules. If so, some of the difference in assignment of responsibility for concealing exculpatory evidence may simply mean that better record keeping reveals prosecutorial knowledge of the concealed evidence that might otherwise not be noticed.

Similarly, witness tampering by police may be rare in part because the document-heavy investigations of federal white-collar crimes are less likely to turn on the type of testimony that police officers obtain by tampering with witnesses in violent crime cases. For example, twothirds of all exonerations include mistaken or intentionally false identifications of the defendants $(1,778 / 2,400)$, compared to one-third of federal white-collar exonerations $(15 / 46)$.

It's hard, however, to think of an innocent explanation for the rate of federal prosecutorial misconduct in an arena that is always their domain: trial. Prosecutors knowingly permitted witnesses to commit perjury in $26 \%$ of the trials of exonerated federal white-collar defendants (12/46)-almost twice as often as state prosecutors at the trials of murder exonerees (134/904); and they committed some form of misconduct in $39 \%$ of those trials (18/46), compared to $22 \%$ for state murder prosecutors (196/904).

The picture that emerges suggests that prosecutors dominate federal white-collar prosecutions in a way that largely determines the extent and nature of all official misconduct, for better and for worse. Prosecutorial control over these investigations may well discourage and reduce misconduct by law enforcement officers. It's possible that it reduces the overall rate of misconduct in such cases; we don't have the sort of data that would permit even an educated guess on the overall frequency of official misconduct in any category of criminal cases, as we've noted. ${ }^{198}$

However, when there is official misconduct in federal white-collar exonerations, prosecutors are at the heart of it. They may be able to prevent police misconduct more effectively than state prosecutors, but they don't always do it. The FBI, for example, committed serious misconduct in the investigations of Ted Stevens and of Reddy Annappareddy, but in both cases-and every other similar federal case with police misconduct-so did the prosecutors.

\footnotetext{
197 See supra Section IV.1.

198 See supra Section II; infra Methodological Appendix.
} 
Why do federal prosecutors commit-and permit-misconduct in white-collar prosecutions? Probably for the same combination of reasons that produces the high rate of official misconduct in murder exonerations: They are strongly motivated to prosecute serious crimes that are difficult to prove; they are convinced of the defendants' guilt but afraid they might not have enough evidence to convince a judge and jury; and, unlike almost all criminal prosecutions, these cases receive a lot of public attention, so failure is humiliating but success can advance a professional or political career. Most prosecutors undoubtedly respond to these pressures by keeping their heads down and doing their job-but some, as we see, cut corners, jump to conclusions, hide evidence that suggests innocence or manufacture evidence of guilt.

It's easy to see how it can happen.

Fraud in the provision of prescription medicines under Medicare and Medicaid is a huge national problem, but difficult and costly to prove. What should a prosecutor do after years of investigating what she believes is a major prescription drug fraud mill, when the evidence just isn't there? Drop the case, of course-and ideally reconsider her belief that the defendant is guilty. But the temptation to conceal and deceive must be strong if that prosecutor remains convinced of the defendant's guilt, and has committed herself to that position in public.

By the time Alaska Senator Ted Stevens was charged with receiving illegal gifts, there had been years of stories and rumors that he had used his public position improperly to amass personal wealth. ${ }^{199}$ But he had never been charged with a crime or other actionable misconduct. The prosecutors who did charge him were probably convinced of his guilt, but as the evidence came in, they had no case. So, at a trial in the glare of the national media, they concealed evidence that would have led to an acquittal if not a dismissal.

We know of dozens of other federal white-collar exonerations in which prosecutorial misconduct led to false convictions. We do not know how often that has happened in cases of innocent defendants whose convictions still stand.

199 See Chuck Neubauer \& Richard T. Cooper, Senator's Way to Wealth Was Paved with Favors, Los Angeles Times (Dec. 17, 2003). 


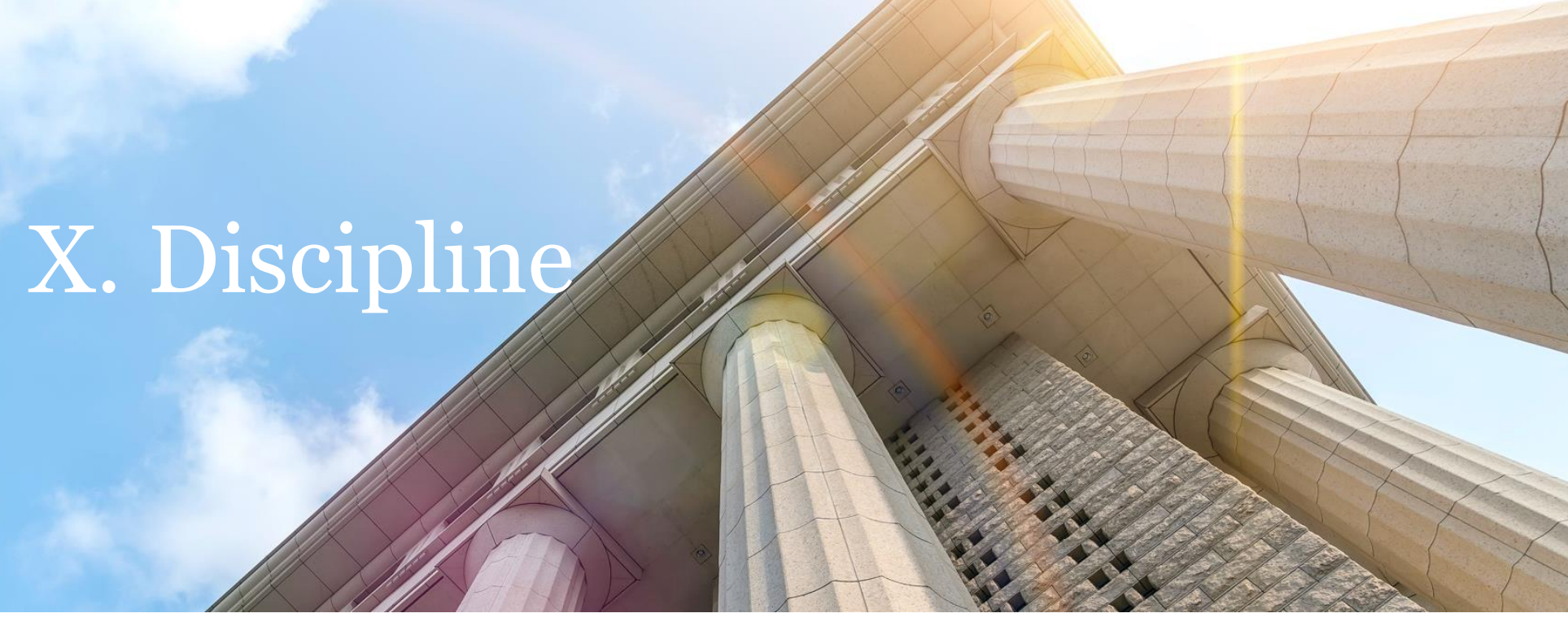

\section{IN GENERAL}

How many of the prosecutors, police officers, forensic analysts and child welfare workers are disciplined for misconduct that leads to false convictions? It happens, but not often. We know that some discipline, broadly defined, was imposed in $17 \%$ of exonerations with known official misconduct $(219 / 1,295)$, but not in the remaining $83 \%$.

Misconduct often comes in bunches. In most cases in which discipline for misconduct was imposed, the officials who were disciplined committed misconduct of the same general sort in several or many other cases as well-sometimes cases that produced exonerations, sometimes not-but formal discipline was limited to one or a few, or was not attached to any specific case. For example, in 2011 Chicago Police Commander Jon Burge-who had already been fired from the police department for a pattern of misconduct over several years-was convicted of perjury for lying about his role as the leader of a group of officers who tortured numerous suspects. ${ }^{200}$ We view that conviction as discipline that was imposed for every case in which he was responsible for misconduct of that type. Overall, in $70 \%$ of exonerations with discipline for official misconduct, that discipline was imposed for general patterns of behavior or for a case other than the specific exoneration at hand (154/219).

Disciplinary proceedings may take months or years from the initiation to conclusion. We only count those cases in which punishment was actually imposed, occasionally in reduced measure. We do not count $1 \%$ of exonerations with misconduct in which discipline was imposed but later reversed $(15 / 1,295)$, or a handful in which, as of our last information, proceedings were still pending final resolution $(10 / 1,295)$.

Prosecutors who committed misconduct in criminal cases that led to exonerations were rarely disciplined; it happened only $4 \%$ of the time. Police officers who committed misconduct were disciplined almost five times as often as prosecutors, in $19 \%$ of the cases; and forensic analysts who committed misconduct were more than twice as likely to be disciplined as police officers, in

${ }^{200}$ See infra, Section XII.1.b.

Government Misconduct and Convicting the Innocent The Role of Prosecutors, Police and Other Law Enforcement 
$47 \%$ of the cases. We know of no exoneration in a case in which a child welfare worker was disciplined. See Table 22.

Table 22: Rate of Discipline among Exonerations with Misconduct, by Type of Official who Committed Misconduct*

\begin{tabular}{cccc}
\multicolumn{4}{c}{ Misconduct By: } \\
\hline Prosecutor & $\begin{array}{c}\text { Police } \\
\text { Officer }\end{array}$ & $\begin{array}{c}\text { Forensic } \\
\text { Analyst }\end{array}$ & $\begin{array}{c}\text { ANY LAW } \\
\text { ENFORCEMENT } \\
\text { OFFICIAL }\end{array}$ \\
\hline $4 \%$ & $19 \%$ & $\begin{array}{c}47 \% \\
(35 / 75)\end{array}$ & $\begin{array}{c}17 \% \\
(219 / 1,295)\end{array}$ \\
\hline
\end{tabular}

* Some cases include misconduct by more than one type of official.

Prosecutors and police officers are essential players in all criminal cases; forensic analysts participate in a minor fraction. As a result, misconduct by forensic analysts occurred in only about $3 \%$ of all exonerations - and, despite the comparatively high rate of discipline for that misconduct, it only happened in about $1 \%$ of all cases $(35 / 2,400)$. Prosecutors were also disciplined in about $1 \%$ of all exonerations $(26 / 2,400)$, and police officers in about $7 \%$ $(160 / 2,400)$.

Among the major crimes that account for about five-sixths of known exonerations, the rate of discipline varies greatly. It's highest by far in drug-crime exonerations, where some form of discipline was imposed in $74 \%$ of cases with official misconduct, followed at some distance by sexual assault at $17 \%$, and murder and robbery at $9 \%$ each. White-collar and child sex abuse exonerations bring up the rear, with discipline in $3 \%$ of cases with misconduct each. See Table 23 . 
Table 23: Rate of Discipline among Exonerations with Misconduct, by Type of Official who Committed Misconduct, for Major Crime Categories*

\begin{tabular}{|c|c|c|c|c|}
\hline & \multicolumn{4}{|c|}{ Misconduct By: } \\
\hline & Prosecutor & $\begin{array}{l}\text { Police } \\
\text { Officer }\end{array}$ & $\begin{array}{c}\text { Forensic } \\
\text { Analyst }\end{array}$ & $\begin{array}{c}\text { ANY LAW } \\
\text { ENFORCEMENT } \\
\text { OFFICIAL }\end{array}$ \\
\hline Murder & $\begin{array}{c}4 \% \\
(15 / 404)\end{array}$ & $\begin{array}{c}7 \% \\
(32 / 435)\end{array}$ & $\begin{array}{c}38 \% \\
(13 / 34)\end{array}$ & $\begin{array}{c}9 \% \\
(59 / 652)\end{array}$ \\
\hline Child Sex Abuse & $\begin{array}{l}3 \% \\
(2 / 67)\end{array}$ & $\begin{array}{c}0 \% \\
(0 / 76)\end{array}$ & $\begin{array}{l}25 \% \\
(1 / 4)\end{array}$ & $\begin{array}{c}3 \% \\
(3 / 120)\end{array}$ \\
\hline Sexual Assault & $\begin{array}{l}3 \% \\
(2 / 64)\end{array}$ & $\begin{array}{l}3 \% \\
(2 / 68)\end{array}$ & $\begin{array}{l}59 \% \\
(17 / 29)\end{array}$ & $\begin{array}{c}17 \% \\
(21 / 126)\end{array}$ \\
\hline Robbery & $\begin{array}{c}9 \% \\
(3 / 33)\end{array}$ & $\begin{array}{l}5 \% \\
(1 / 19)\end{array}$ & - & $\begin{array}{c}9 \% \\
(4 / 46)\end{array}$ \\
\hline Drug Crimes & $\begin{array}{c}3 \% \\
(1 / 29)\end{array}$ & $\begin{array}{c}84 \% \\
(90 / 107)\end{array}$ & $\begin{array}{c}100 \% \\
(1 / 1)\end{array}$ & $\begin{array}{c}74 \% \\
(91 / 123)\end{array}$ \\
\hline $\begin{array}{l}\text { White-collar } \\
\text { Crimes }\end{array}$ & $\begin{array}{c}3 \% \\
(1 / 36)\end{array}$ & $\begin{array}{l}0 \% \\
(0 / 7)\end{array}$ & $\begin{array}{l}0 \% \\
(0 / 1)\end{array}$ & $\begin{array}{c}3 \% \\
(1 / 39)\end{array}$ \\
\hline $\begin{array}{l}\text { ALL CASES WITH } \\
\text { MISCONDUCT }(1,295)\end{array}$ & $\begin{array}{c}4 \% \\
(26 / 729)\end{array}$ & $\begin{array}{c}19 \% \\
(160 / 843)\end{array}$ & $\begin{array}{l}47 \% \\
(35 / 75)\end{array}$ & $\begin{array}{c}17 \% \\
(219 / 1,295)\end{array}$ \\
\hline
\end{tabular}

* Some cases include misconduct by more than one type of official.

** The total number of child sex abuse cases with misconduct includes 48 cases with misconduct by child welfare workers, most of which also include misconduct by other officials.

The rates of discipline for particular types of law enforcement officials vary a good deal for prosecutors and forensic analysts-from 3\% to $9 \%$ for prosecutors, and from $25 \%$ to $59 \%$ for forensic analysts (not counting two crime categories with only one case of misconduct each). For police, however, the range is huge. Discipline was imposed in $84 \%$ of 107 drug crime exonerations in which a police officer committed misconduct, but in none of 76 child sex abuse cases in which they did so. See Table 23.

"Discipline" for official misconduct can come from three separate sources of authority:

Employment. The agency that employs misbehaving officials may reassign, suspend, demote or fire them, or pressure them to resign.

Professional. If the official has a professional license or certification, the licensing or certifying authority (for example, a state bar) may revoke or suspend that license or 
certification, or reprimand the official who holds it. ${ }^{201}$ We do not know of any professional discipline of police officers who worked on the cases we list.

Criminal. If the misconduct is a crime, the official may be prosecuted and convicted. ${ }^{202}$

In the normal course of events, law enforcement officers who are convicted of crimes related to their work are also disciplined by their employers. In most cases, they are fired if they weren't already forced to resign or retire. Similarly, a convicted official who has a license or a certificate is very likely to have it revoked or suspended, or to be reprimanded or otherwise disciplined by the professional association involved. We only tabulate employment or professional discipline for officials who were not convicted of crimes based on the same pattern of misconduct. For officials who were convicted of crimes, those forms of discipline (if applicable) should be assumed.

Prosecutors who committed misconduct were highly unlikely to be disciplined in any manner, as we mentioned. In particular, in only two of 727 cases with prosecutorial misconduct was a prosecutor convicted criminally. By contrast, in 127 exonerations, police officers who worked on the cases were convicted of crimes because of misconduct that contributed to false convictions; and forensic analysts were disciplined by their employers in more than a third of exonerations in which they committed misconduct. See Table 24 .

201 For prosecutors, we also count judicial discipline-reprimanding prosecutors, holding them in contempt, and removing them from the case in question-as professional discipline. That occurred in three cases.

202 Successful civil lawsuits for monetary damages could, in theory, be a form of discipline for the offending parties, but we don't count them here for a variety of reasons. The most important are that civil damages are almost always paid by the agencies or local governments that employ the offending officials, or by their insurance companies, rather than the official actors themselves; and that most successful claims end in settlements, with no findings or admissions of misconduct. 
Table 24: Rate of Discipline among Exonerations with Misconduct, by Type of Official who Committed Misconduct and Form of Discipline*

\begin{tabular}{|c|c|c|c|c|}
\hline & \multicolumn{4}{|c|}{ Misconduct By: } \\
\hline & Prosecutor & $\begin{array}{l}\text { Police } \\
\text { Officer }\end{array}$ & $\begin{array}{c}\text { Forensic } \\
\text { Analyst }\end{array}$ & $\begin{array}{c}\text { ANY GOVERNMENT } \\
\text { OFFICIAL }\end{array}$ \\
\hline Employment $^{\star \star}$ & $\begin{array}{c}2 \% \\
(11 / 729)\end{array}$ & $\begin{array}{c}4 \% \\
(33 / 843) \\
\end{array}$ & $\begin{array}{l}37 \% \\
(28 / 75) \\
\end{array}$ & $\begin{array}{c}5 \% \\
(70 / 1,295) \\
\end{array}$ \\
\hline Professional $^{\star \star}$ & $\begin{array}{c}2 \% \\
(14 / 729)\end{array}$ & - & $\begin{array}{c}9 \% \\
(7 / 75)\end{array}$ & $\begin{array}{c}2 \% \\
(21 / 1,295)\end{array}$ \\
\hline Criminal & $\begin{array}{l}0.3 \% \\
(2 / 729)\end{array}$ & $\begin{array}{c}15 \% \\
(127 / 843)\end{array}$ & $\begin{array}{c}4 \% \\
(3 / 75)\end{array}$ & $\begin{array}{c}10 \% \\
(133 / 1,295)\end{array}$ \\
\hline $\begin{array}{l}\text { ANY TYPE OF } \\
\text { DISCIPLINE }(1,295)\end{array}$ & $\begin{array}{c}4 \% \\
(26 / 729)\end{array}$ & $\begin{array}{c}19 \% \\
(160 / 843)\end{array}$ & $\begin{array}{c}47 \% \\
(35 / 75)\end{array}$ & $\begin{array}{c}17 \% \\
(219 / 1,295)\end{array}$ \\
\hline
\end{tabular}

* Some cases include more than one type of discipline and some cases misconduct by more than one type of official.

** Employment and Professional discipline are not listed for any official who was convicted of a crime in the same case or a similar case.

As with misconduct itself, we have missed cases in which discipline was imposed. That is least likely for criminal convictions of law enforcement officials-especially of prosecutors-which are uncommon and conspicuous events. It is most likely for comparatively mild discipline by employers, such as reassignment or demotion, which may go unnoticed if it is not deliberately hidden.

In the sections that follow, we focus separately on each of these three categories of official actors, and discuss differences in discipline by crime and by type of discipline that was imposed.

\section{DISCIPLINE BY CATEGORY OF GOVERNMENT OFFICIAL}

\section{a. Prosecutors}

Prosecutors are hardly ever disciplined for misconduct that contributes to false convictions. We've probably missed some cases in which prosecutors received employment or professional discipline that did not end their careers in prosecution-suspensions, private reprimands, and so forth-but the general pattern is no surprise. Several earlier studies found the same pattern in other contexts, as we have discussed. ${ }^{203}$

203 Supra Section II.1. See also Ken Armstrong \& Maurice Possley, Trial \& Error: How Prosecutors Sacrifice Justice to Win. Part 1: The Verdict: Dishonor, Chi. Trib. (Jan. 11, 1999); Ctr. for Pub. Integrity, Harmful Error: Investigating America's Local Prosecutors (2003); Kathleen M. Ridolfi \& Maurice Possley, Preventable Error: A Report On Prosecutorial Misconduct In California, 1997-2009, A Veritas Initiative Report (2010). 
We know of some discipline for prosecutors in $4 \%$ of exonerations with prosecutorial misconduct: 15 murders, nine other violent felonies, a drug case and a white-collar crime. In most of those cases, the discipline that was imposed was comparatively mild.

Eleven prosecutors were disciplined by the offices that employed them: two were fired, four resigned or retired under pressure, and five were demoted, suspended or received additional training. Fourteen prosecutors were disciplined in their professional capacity as lawyers, but only three were disbarred, one of them for misconduct in the case of two exonerees who were tried together. Two others were suspended, four were reprimanded, and three received sanctions from judges that were limited to the cases at issue.

Only two prosecutors in exonerations were convicted of crimes for professional misconduct, both in highly notorious cases, and both received nominal sentences: ${ }^{204}$

In 2013, former Williamson County (Texas) District Attorney Ken Anderson served four days in jail for contempt for concealing exculpatory evidence that would have prevented the murder conviction of Michael Morton, who spent 24 years in prison.

In 2007, Michael Nifong, the former District Attorney of Durham County, North Carolina, spent one day in jail, also for criminal contempt, for concealing exculpatory DNA evidence in a nationally publicized prosecution of three white members of the Duke University Lacrosse team who were falsely accused of raping a Black exotic dancer. ${ }^{205}$ There was no exoneration in the Duke Lacrosse case; the defendants were never convicted because charges were dropped before trial. In 2016, however, the attention Nifong received in that case helped secure a murder exoneration for Darryl Howard, whom Nifong had prosecuted and convicted of murder in 1991, and in whose case he had also concealed crucial exculpatory evidence. We count the discipline in the Duke Lacrosse case as applying to Howard's exoneration because the prosecutor who committed it was punished for similar behavior in a different case.

Nifong and Anderson were both also disbarred and lost their jobs. ${ }^{206}$

204 See supra Section VIII.2.b. and infra Section X.2.a.

205 Shaila Dewan, Duke Prosecutor Jailed; Students Seek Settlement, N.Y. Times, Sept. 8, 2007.

206 One reason that few prosecutors are charged with crimes for misconduct in criminal cases may be that the common form of state statutes of limitations makes that impossible in most cases. Ken Anderson, for example, could have been charged with evidence tampering under Texas Penal Code $\S \S 37.09$ and 37.10, but only if charges had been filed within three years of the commission of the misconduct-which, as is typical for exonerations, would have been more than 20 years before his misconduct was discovered. Instead he was charged with criminal contempt under Texas Government Code $\S 21.002$ (a) because he violated a court order and lied to the trial judge; the statute of limitations for that offense only begins to run when the contempt is discovered. Barry Scheck, Four Reforms for the Twenty First Century, 96 Judicature 323 (2013) at 332 n.50. In 2016, California enacted Penal Code §141(c), which makes it a felony for a prosecutor "to intentionally and in bad faith" conceal or destroy exculpatory evidence in a criminal case. The applicable statute of limitations is California Penal Code $\S 803$ (c), which provides that "A limitation of time prescribed in this chapter does not commence to run until the discovery of an offense...." That solves the statute of limitations problem-if the authorities are interested in filing felony charges for concealing exculpatory 


\section{b. Police officers}

Police officers were disciplined for misconduct in exonerations more than six times as often as prosecutors, 160 times vs. 26. In 79\% of those cases, officers were convicted of crimes (127/160); in $20 \%$, officers were disciplined by the police forces for which they worked (33/161); we know of no cases in which police officers received professional discipline for misconduct that contributed to false convictions.

These numbers, however, may be misleading in two respects: (i) On the one hand, the number of officers who were disciplined for misconduct, especially the number of officers who were convicted of crimes, is considerably smaller than the number of exonerations in which those officers helped secure false convictions. (ii) On the other hand, we know that many instances of discipline of police officers short of criminal conviction are concealed from public view; we don't know how often that occurred among exonerations with misconduct, or in which cases.

\section{i. Criminal conviction in related cases}

We know of 92 exonerations in Chicago in which police officers committed misconduct in investigating the cases and were later convicted of crimes for that misconduct or for similar misconduct in other cases, and another three such exonerations in a Chicago suburb within Cook County, Illinois. However, that does not mean that these cases produced 95 separate criminal convictions of police officers. Far from it.

Sixty-six of the 95 Cook County cases were in the Sergeant Watts group exoneration. ${ }^{207}$ In all 66 cases, the defendants were framed for possession of drugs (or in one case, a gun) that officers planted. The findings of discipline in these exonerations were based on two convictions for acts that were part of the same pattern of criminal misconduct, but occurred in a single sting case in federal court: the conviction of Sergeant Ronald Watts himself, who participated directly in some of the 66 exonerations and supervised the officers in all of them, and that of his subordinate, Officer Kallatt Mohammed, who played a direct role in several of the Watts exonerations.

An additional 19 Cook County exonerations with criminal discipline are torture cases in which Chicago Police Commander Jon Burge-who was convicted of perjury in a related federal caseplayed a role as supervisor or direct participant.

In sum, 85 of the 95 cases of criminal discipline of police officers for misconduct in exonerations in Cook County are based on three criminal convictions. ${ }^{208}$ More telling yet: those three

evidence. So far, we are not aware of any charges that have been filed alleging violations of California Penal Code $\S 141(\mathrm{c})$.

207 See supra Section III.3.c.i.

208 The remaining 10 Cook County cases with criminal discipline of police officers include six exonerations based on misconduct by the officers in the now disbanded "Special Operations Section" [SOS] of the Chicago Police department; a total of eleven officers were convicted of crimes for their work in that unit. In addition, two individual Cook County cases had one conviction of an officer each; and a set of three related cases led to two convictions. The 32 exonerations outside of Cook County with criminal convictions of police officers also include several groupings of a few cases each. The most noteworthy are the Norfolk Four exonerations in Virginia whose confessions were 
convictions of Watts, Mohammed and Burge account for two-thirds of all exonerations in the country in which police officers who conducted or supervised the investigations were convicted of crimes for the type of misconduct they committed in those cases (85/127). Indeed, the 66 Watts exonerations alone comprise more than half the national total.

The large number of criminal convictions for misconduct in the Watts cases is a direct consequence of the structure of that group exoneration. ${ }^{209}$ As we discussed, most group exonerations are cases that only came to light after it becomes known that the officers involved were guilty of concerted schemes of misconduct, usually planting drugs on innocent suspects. That is also true for some of the Burge exonerations: they were identified as candidates for exoneration because Burge was involved, after he was exposed for presiding over a program of systematic torture, fired and eventually convicted.

For the Watts cases, the exonerations were also a direct response to the discipline itself-the convictions of Watts and Mohammed in federal court. Since the Watts cases were identified for exoneration by the participation of officers who'd been convicted of crime, all of them, by definition, include criminal discipline for those officers.

Neither Watts nor any of his subordinates was convicted of any crimes directly related to the many extreme miscarriages of justice they perpetrated. Internal police investigations of 15 other officers were still pending two-and-a-half years after the first large group of Watts exonerations and nearly seven years after Watts was convicted in federal court. ${ }^{210}$ As far as we know, there have been no state criminal investigations of Watts or any of the officers who worked under him.

Even though many fewer police officers were convicted of crimes than the number of cases with such convictions suggests, police are far more likely than prosecutors to be criminally convicted and imprisoned for misconduct that leads to false convictions. We don't have a precise count of the police officers who were convicted across these 127 exonerations-in some cases, there may be more convictions than we have been able to identify-but we know of at least 30, and some served substantial periods of time in prison. ${ }^{211}$ Burge was sentenced to 41 / 2 years in prison, Watts to 22 months, and Detective Robert Ford, who coerced the confessions of four innocent sailors in a Virginia rape-murder case, was sentenced to 12 1/2 years in prison for extortion and for lying to the FBI about related misconduct.

extracted by the misconduct of a single officer who was later convicted of related misconduct, and the convictions of five murder codefendants in Los Angeles, who were framed by a single officer who went to prison for a pervasive pattern of misconduct on the Rampart Group Exoneration.

209 See supra Section III.3.c.i.

210 Editorial Board, Take the lid off probes of officers tied to wrongful convictions, Chicago Sun Times, Jun 14, 2020.

211 We know of 18 officers who worked in Cook County, Illinois, who were among those convicted in crimes for misconduct they committed in interrogations, or for similar misconduct in other cases-almost certainly more than half the total for the country. On this issue, as with false confessions and the use of violence in interrogation, Cook County is unique. 
The only two prosecutors who were convicted of any sort of criminal behavior in connection with exonerations served a total of five days in jail between them.

ii. Unreported employment and professional discipline

As we mentioned, we don't know of any police officer who was disciplined by a professional organization for misconduct that contributed to the conviction of an exoneree. But it probably happened.

Forty-four states require that police officers be certified or licensed after taking a training program that satisfies state requirements. Those requirements are typically administered by a state Police Officer Standards and Training ("POST") Commission that also has the authority to decertify an officer or revoke their license. ${ }^{212}$ That disciplinary process, however, is generally secret. There is a national database of decertifications, the National Decertification Index (NDI), that is maintained by the International Association of Directors of Law Enforcement Standards and Training, but access is limited to law enforcement and POST organizations. ${ }^{213}$ Nonetheless, USA Today and The Invisible Institute in Chicago have put together a database with information on some 30,000 decertifications stretching back over dozens of years. ${ }^{214}$ Most were based on use of excessive force, drug or alcohol abuse, domestic violence, or other misconduct unrelated to criminal investigations, but in about $15 \%$ of cases in which reasons for decertification are listed, they include "dishonesty" or "official misconduct." 215

Decertification means that the officers involved lost their jobs in the police forces at which they worked when the misconduct occurred (although decertified officers are sometimes hired by other police departments ${ }^{216}$ ). Terminating a police officer's employment is a reasonably visible event. Nonetheless, it's likely that unbeknownst to us, some officers who helped obtain convictions of exonerees were decertified for misconduct in those cases-and it's very likely that we have missed decertifications for similar misconduct in other criminal cases.

It is also highly likely that we missed cases in which police officers were disciplined by their departments but not terminated. In some states-including Florida, Texas, Minnesota and Arizona-employment information on police officers, including their disciplinary records, is available to the public. ${ }^{217}$ In others, including New Hampshire, Colorado and Vermont, that

212 Roger Goldman, Importance of State Law in Police Reform, 60 Saint Louis Univ. L. J. 363, 381 (2016); See Barry Scheck, The Integrity Of Our Convictions: Holding Stakeholders Accountable In An Era Of Criminal Justice Reform, 48 Geo. L.J. Ann. Rev. Crim. Proc. iii, xviv-xxv (2019).

213 “About NDI," International Association of Directors of Law Enforcement Standards and Training.

214 John Kelly and Mark Nichols, Search the list of more than 30,000 officers banned by 44 states, USA Today, Oct. 14, 2019.

215John Kelly and Mark Nichols, We found 85,000 cops who've been investigated for misconduct. Now you can read their records, USA Today, June 11, 2020.

216 See Goldman, supra note 212.

217 Jonathan Abel, Brady's Blind Spot: Impeachment Evidence in Police Personnel Files and the Battle Splitting the Prosecution Team, 67 Stan. L. Rev. 743, 770 (2015). 
information is secret; ${ }^{218}$ California was in that group until late 2019. ${ }^{219}$ And in some states, including New York, Maryland, West Virginia and Oregon, prosecutors have the authority to access police disciplinary records (and then, presumably, disclose them to the defense if they contain exculpatory evidence)-but many prosecutors don't know they have that access, or don't use it. ${ }^{220}$ And if records are available, they may be incomplete: many departments have contracts with police unions that require that disciplinary records be erased after a period that may be as short as two years or less. ${ }^{221}$

Disciplinary measures that are hidden from view may be better than no discipline at all, but they have limited impact. They are less likely to deter officers from committing misconduct, and they make it harder for the other participants in the process-prosecutors, defense attorneys, judges and juries-to identify those officers who commit misconduct and lie about it repeatedly.

\section{c. Forensic Analysts}

All of the forensic analysts who were disciplined for their roles in convictions that led to exonerations had committed forensic fraud. In four-fifths of those cases-28 out of 35-the punishment was imposed by the agencies they worked for.

In three cases, forensic analysts were convicted of crimes: one for a lab scandal that included writing false drug analysis reports; and two others for lying about their credentials in trial testimony. ${ }^{222}$ In seven cases, forensic analysts had professional licenses or memberships in professional societies suspended or revoked (including three in which the analyst was also disciplined by her employer). In 18 cases, the forensic analysts were fired from their jobs (counting one who resigned as he was about to be fired), and in 10 others, the analyst was reassigned to administrative duties.

The rate of discipline for forensic analysts is comparatively high: $47 \%$ of all known cases in which they committed misconduct, and $56 \%$ of cases in which they committed forensic fraud, that we know of (35/62). But-as with discipline for police officers-the number of analysts who were disciplined is considerably smaller than the number of exonerations in which those analysts participated.

In most cases, the analysts who were disciplined were serial offenders. Altogether, only 13 different analysts were disciplined for their misconduct across these 35 cases-and six of them were responsible for $80 \%$ of the total (28/35). In fact, in nearly half of all cases with discipline

218 Id. at $762-770$.

219 Marco della Cava, When police misconduct occurs, records often stay secret. One mom's right to change that, USA Today, Oct. 14, 2019.

220 Abel, supra note 217 , at 775-779.

${ }^{221}$ DeRay McKesson, et al., Police Union Contracts and Police Bill of Rights Analysis, June 29, 2016.

222 The sentences were comparatively mild: 30 days, 9 months home confinement, probation. The three are: Dollard, Jermaine (linked); LeFever, Virginia; Kotler, Kerry. 
for a forensic analyst, the offending analyst was either Fred Zain (seven exonerations in West Virginia and Texas) or Pamela Fish (10 cases in Chicago).

As we noted earlier, Zain, Fish, and other serial fraudsters are likely to be overrepresented among known cases of forensic fraud. ${ }^{223}$ After they are exposed, otherwise inconspicuous cases they worked on are likely to be reexamined and misconduct that had been missed brought to light. At the same time, their notoriety also makes them likely targets for discipline.

\section{SUMMARY}

The rate of known discipline for misconduct that led to the convictions of innocent exonerees is low, $17 \%$ all told. That's an undercount, inevitably-especially for police discipline by employers, which may fly under the radar, or, in some departments, be concealed.

Very few prosecutors were disciplined in any manner. It occurred in $4 \%$ of exonerations with prosecutorial misconduct, 26 cases altogether. In each case, the prosecutor was disciplined for misconduct in the prosecution of an individual defendant or a pair of codefendants. Only two prosecutors were convicted of crimes for their misconduct, both for contempt of court, and both received minimal sentences.

Police officers and forensic analysts were much more likely to be disciplined; it happened in $19 \%$ and $47 \%$ of the cases in which we know that they committed misconduct, respectively. In almost $80 \%$ of exonerations in which police officers were disciplined, they were convicted of crimes; by contrast, in $80 \%$ of cases in which forensic analysts were disciplined, they were fired or reassigned by their agencies to non-investigative duties.

There are many more exonerations in cases in which officers or analysts were disciplined than officers or analysts who were the subjects of that discipline. In 30\% of all known exonerations with discipline, that discipline consisted of two criminal convictions, those of Chicago Police Sergeant Ronald Watts and Officer Kallatt Mohammed, who supervised or participated in framing 66 innocent drug defendants who were later exonerated (66/219). More than half of all exonerations with discipline are based on punishments meted out to seven individuals: Watts and Mohammed plus three other police officers ${ }^{224}$ and two forensic analysts ${ }^{225}(111 / 219)$.

As we have pointed out, the notoriety of some analysts who committed forensic fraud on a regular basis drew attention to cases that would otherwise be overlooked, and produced exonerations of innocent defendants who would not otherwise have been cleared. ${ }^{226}$ The same applied to Jon Burge and the torture cases he presided over ${ }^{227}-$ and in both contexts, the same

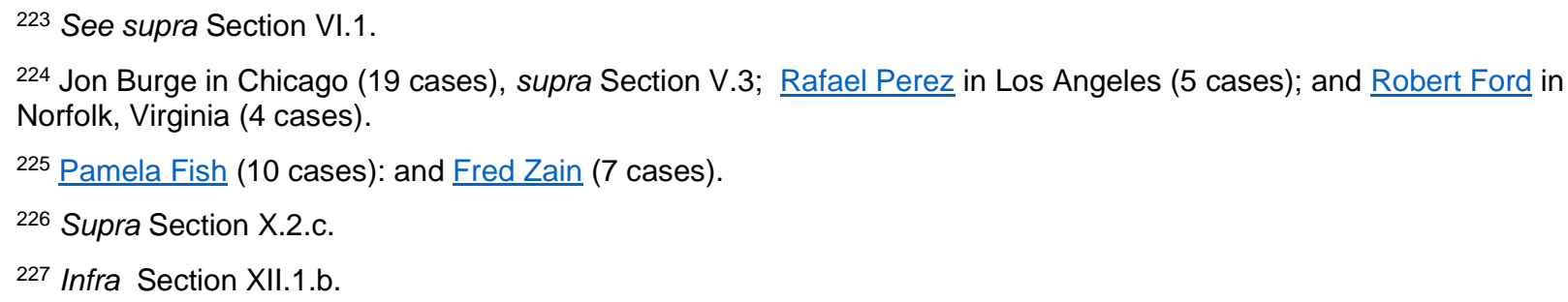


process also produced disciplinary actions that applied across all the cases involved, in both groups.

The connection is even more direct for the 66 Watts group exonerations in Chicago. None of these comparatively low-level drug convictions would have resulted in exoneration, regardless of the defendants' innocence, if they had not been part of a notorious group. And they all include discipline because it was the discipline itself-the federal convictions of two officers involved, and the publicity that followed-that led to the reinvestigations that produced these exonerations.

While the publicity surrounding notorious malefactors such as Sergeant Watts and Commander Burge has led to many exonerations -85 in Cook County alone-it has not led to a corresponding imposition of discipline against other police officers who participated in the same misconduct. No state criminal charges have been filed against any officer connected with these exonerations, and, as far as we know, the only officers disciplined in any manner are the three who were convicted of federal crimes. 


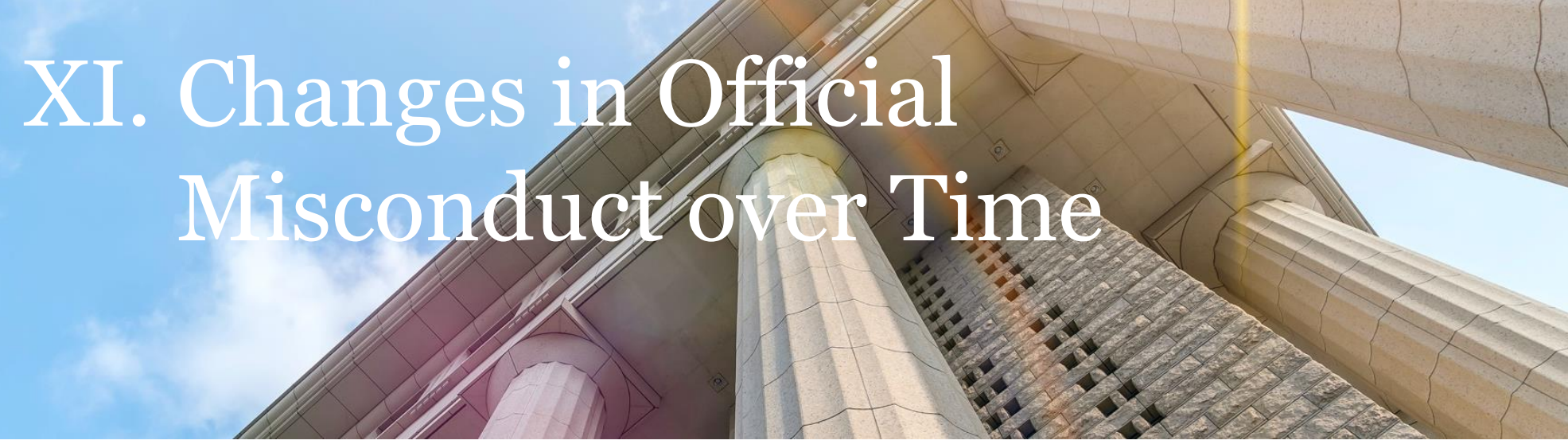

\section{IN GENERAL}

Has official misconduct in criminal investigations and prosecutions in the United States changed over time? Is it more common than in the past? Less common? Different? The answers to these questions would be highly useful for any attempts to reduce misconduct in the future. We can say something about this issue, but less than we'd like.

There are two major difficulties:

We don't know about most misconduct in criminal cases, as we've discussed. ${ }^{228}$ As best we can tell, the majority of victims of torture in Chicago were guilty of the crimes they were convicted of. Others were never convicted at all. Neither group appears in our data because the misconduct did not contribute to false convictions. We also don't know about misconduct that did contribute to false convictions in cases that did not produce exonerations. And even among the exonerations we report, we don't know how much official misconduct has remained successfully hidden from view. The best we can do is report on changes in known misconduct that contributed to the false convictions in known exonerations.

Measuring change in this domain is very difficult. In part, that follows from the previous problem: since we don't know how often this behavior actually occurs, it's hard to tell whether its frequency has changed. But even if we limit ourselves to what we can observe-the numbers of exonerations with known misconduct, or with particular types of known misconductchanges over time are extremely difficult to interpret. The main problem is the time lag from the commission of misconduct to its discovery.

Usually, when we discuss a date in this report we are interested in the time of exoneration, the final act in the legal story of a wrongful conviction. Here, however, we are interested in official misconduct that contributed to the false conviction, the erroneous legal judgment that an exoneration eventually corrected. We peg that behavior to the date of conviction, the last possible time when misconduct can influence a criminal conviction.

${ }^{228}$ Supra Section III.2. 
After that, of course, it may be years before the defendant is exonerated and becomes eligible for inclusion in our database. The average time from conviction to exoneration is about 11 years for all exonerations; for murder-the most common category of exoneration and the one with the highest rate of official misconduct-the average lag is almost 15 years, and more than 60 murder exonerations happened more than 30 years after conviction.

These time lags mean that we may have to wait decades before we can use data on exonerations to accurately identify changes in official misconduct that might already have occurred in murder convictions in the past few years.

To illustrate, there were 414 murder exonerations with official misconduct among convictions in the 16-year period from 1987 through 2002, but only 68 such exonerations from convictions in the next 16 years, from 2003 through 2018-one-sixth as many.

At first glance, this suggests a sharp decrease in false murder convictions caused by misconduct, starting in the early years of the twenty-first century-but that impression is misleading. For cases with convictions before 2003, the average time from conviction to exoneration for a murder with official misconduct was more than 17 years. Assuming that time lag is similar for more recent cases, we still don't know about most exonerations that will eventually accumulate for murder convictions with official misconduct that occurred in 2003, let alone those in 2017 or 2018. Twenty years from now, when we know about virtually all murder exonerations that will ever occur for convictions from 2003 through 2018, we might see a reduction in misconduct compared to the period before 2002, or an increase, or no change.

In short, on many issues and for most types of exonerations, it's simply too early to tell whether there has been change in the occurrence of misconduct over time. ${ }^{229}$ The problem is particularly severe for detecting reductions in misconduct: as we saw, an apparent decline may just reflect a time lag.

But there are exceptions. In a few contexts-improper questioning of children, misconduct in interrogations and forensic fraud-we see strong evidence of decreases in official misconduct even with these limited data.

In addition, in one setting-federal white-collar crime prosecutions - we see clear evidence of a recent increase in official misconduct. As we will see, detecting an increase is easier in this context than detecting a decrease; if anything, the time lag means we may underestimate it.

229 The same issue can occur in medicine. Imagine that workers in canneries have been contracting a form of stomach cancer at a high rate because of workplace exposure to lead, but that starting in 2010 canaries have provided protective clothing that may reduce that exposure and prevent many of these cancers. If the average time from initial exposure to diagnosis of the disease is 25 years, we may have to wait until 2030 or 2040 to begin to learn whether the protective clothing is effective. 


\section{IMPROPER QUESTIONING OF A CHILD VICTIM ${ }^{230}$}

Improper questioning of children has decreased sharply since the mid-1990s. It occurred in $24 \%$ of child sex abuse exonerations (64/270) overall, but $77 \%$ of those cases were part of the child sex abuse hysteria epidemic that lasted from the mid-1980s into the late 1990 (49/64). The last child sex abuse hysteria exonerations were for convictions in 1998; since then, only a handful of ordinary child sex abuse exonerations have included this improper and often abusive form of interrogation. Overall, this improper questioning of children occurred in $28 \%$ of child sex abuse exonerations from convictions through 2002 (58/207)-about 4\% of all exonerations in that period-but only $10 \%$ of such exonerations from convictions since $2003(6 / 63)$, or less than $1 \%$ of all exonerations.

\section{VIOLENCE AND OTHER MISCONDUCT IN INTERROGATIONS ${ }^{231}$}

The frequency of misconduct in interrogations-and especially, violence in interrogations-has dropped dramatically in the past 16 years. As we've mentioned, violence and other misconduct in interrogations is primarily an issue in murder investigations. More than three-quarters of exonerations with misconduct in interrogations are murder cases (126/165), as are 84\% of exonerations with interrogations that included violence or the threat of violence (88/105). The change in the raw numbers for murder interrogations is dramatic:

Police officers committed misconduct in 119 interrogations in exonerations from murder convictions through 2002; they used or threatened physical violence in 86 of those interrogations.

Police committed misconduct in only seven murder interrogations of exonerees who were convicted since the beginning of 2003-a decrease by a factor of 17 (119/7). They used or threatened violence only twice in interrogations since the beginning of 2003, a decrease by a factor of more than $40(86 / 2)$.

This is not, of course, the final word on murder exonerations from convictions between 2003 and 2018. Exonerations yet to come may include additional instances of misconduct and violence in interrogations, but those future cases are unlikely to reverse a trend as strong as what we see here.

The proportion of murder exonerations with violent or otherwise abusive interrogations is a better measure of change than the raw numbers of cases. That proportion is likely to be less sensitive than raw number of cases to the effects of the time lag from conviction to exoneration, since both the numerator and the denominator are reduced by as yet incomplete reporting:

$15 \%$ percent of exonerations of murder convictions before 2003 included misconduct in interrogations (119/782), but only 6\% of exonerations for murder convictions since 2003 (7/126)-a decrease of $73 \%$;

\footnotetext{
230 See supra Section IV.4.

231 See Section V.3.a.
}

Government Misconduct and Convicting the Innocent The Role of Prosecutors, Police and Other Law Enforcement 
$11 \%$ of murder exonerations from the earlier period included violent interrogations (86/782), but only $2 \%$ of those for convictions from 2003 on (2/126) - a decrease of $85 \% .{ }^{232}$

It is hard to imagine how declines that steep could be erased by data on future exonerations. ${ }^{233}$

More than 40\% of pre-2003 murder interrogations with misconduct (50/119) - and more than half of those with physical violence (46/85) - took place in Chicago. ${ }^{234}$ The change since 2003 occurred both in Chicago and elsewhere. The proportion of murder exonerations with misconduct in interrogations went from $46 \%(50 / 108)$ to $20 \%(2 / 10)$ in Chicago, and from $10 \%$ $(69 / 674)$ to $4 \%(5 / 116)$ in other places; use of violence dropped from $46 \%(50 / 108)$ to $20 \%$ (2/10) in Chicago, and from 6\% (39/674) to less than $1 \%(1 / 116)$ in the rest of the country.

\section{FORENSIC FRAUD 235}

Forensic fraud appears to have declined sharply among exonerations for convictions after 2002:

Overall, $5 \%$ of exonerations through 2002 included forensic fraud (72/1598), compared to $0.4 \%$ of all exonerations of defendants convicted in 2003 or later (3/802).

Almost half of exonerations with forensic fraud were murder cases (36/75). Among murder cases, $4 \%$ of exonerations though 2002 included forensic fraud (35/782), but only $1 \%$ of those since $2003(1 / 126)$.

Forensic fraud is one of several types of false or misleading forensic evidence (FMFE). The overall rate of FMFE in exonerations is nearly the same through 2002 (25\%, 400/1598), and since 2003 (24\%, 190/802). The steep decline in forensic fraud persists when we look at FMFE cases separately:

$18 \%$ of exonerations with FMFE from convictions through 2002 included forensic fraud (72/400), but only $2 \%$ of those with FMFE based on convictions since 2003 (3/190);

\footnotetext{
232 We see a similar pattern if we limit our comparison to cases of false confessions. Before $2003,64 \%$ of murder exonerations with false confessions included misconduct in interrogations (119/186), and $46 \%$ included violence (85/185); since 2003, the comparable rates are 39\% (7/18) and $11 \%(2 / 18)$.

${ }^{233}$ By comparison, exonerations after 2003 were only about $40 \%$ less likely than those since 2003 to include witness tampering, that we now know of, and about $40 \%$ less likely to have had exculpatory evidence that was concealed.

The value of a change in the proportion of murder exonerations with misconduct or violence in interrogations as a measure of change in the occurrence of those types of behavior would be undercut if murder exonerations with abusive interrogation have longer time lags from conviction to exoneration than other murder exonerations. That is the case, but the differences are too modest to account for the large disparities in rates of misconduct. For exonerations of murder convictions through 2002, the average time from conviction to exoneration was 16 years for all murder cases, 17.2 years for those with any type or misconduct, 18.9 years for those with misconduct in interrogations, and 19.7 years for those with violent interrogations.

234 See supra Section V.3.a.i.

235 Supra Section VI.1.
} 
18\% of murder exonerations with FMFE and convictions through 2002 had forensic fraud (35/195), compared to $3 \%$ of such cases with convictions since 2003 (1/30).

As with misconduct in interrogations, we are likely to see additional exonerations with forensic fraud for convictions since 2003, but the decrease from earlier years is so great that we are confident the observed decline is real. ${ }^{236}$

\section{FEDERAL WHITE-COLLAR CRIME CASES ${ }^{237}$}

The rate of all federal white-collar crime exonerations, and the rate of such exonerations with official misconduct, have both doubled or more in the past 17 years.

Thirty-two of the 46 federal white-collar exonerees were convicted in the 15 years from 2003 through 2017, more than twice as many as the 14 exonerees who were convicted of federal whitecollar crimes in the 15 years from 1988 through 2002. The number of federal white-collar exonerations with official misconduct doubled from the earlier to the later period, 20 compared to $10 .{ }^{238}$

The time lag from conviction to exoneration for federal white-collar crimes is comparatively short, 3.6 years on average for convictions before 2003, compared to 16 years for murders exonerations. That means that changes in the numbers of exonerations are a better measure of underlying behavior for federal white-collar cases, since we probably already know about the great majority of exonerations for such crimes that will ever occur.

More important, the impact of a time lag from conviction to exoneration depends on the direction of the observed change. It means that an observed decrease in the number of cases may be misleading because there are more exonerations to come. But when we see an increaseas we do for the number of federal white-collar exonerations, with and without misconduct-a time lag to exoneration can only mean that the true increase in federal white-collar exonerations may be larger than what we see so far because future exonerations may further increase the rate for recent cases.

In short, judging from exonerations, the number of convictions of innocent federal white-collar crime defendants has increased sharply since 2003; most of those cases (before and after 2003)

\footnotetext{
236 Our conclusion is limited to forensic fraud in prosecutions for violent felonies, which account for $95 \%$ of exonerations with forensic fraud. In Section XII.2.b.1, we discuss two forensic analysts who falsified tests in thousands of low level drug possession cases in Massachusetts between 2004 and 2013. None of those cases have produced exonerations to date, and it is likely that the great majority of the defendants were guilty. As we discuss below, that sort of misconduct is easier to conceal in cases that routinely produce quick guilty pleas rather than the trials that occur in most exonerations.

237 Supra Section IX.

238 This pattern does not show up for other federal exonerations. We know of 32 exonerations from non-white-collar federal convictions before 2003, and 34 since 2003; 21 of those exonerations from the earlier period included misconduct, and 17 of those from the later period.
} 
involved official misconduct; and all federal white-collar exonerations with misconduct, regardless of time, include misconduct by prosecutors. 

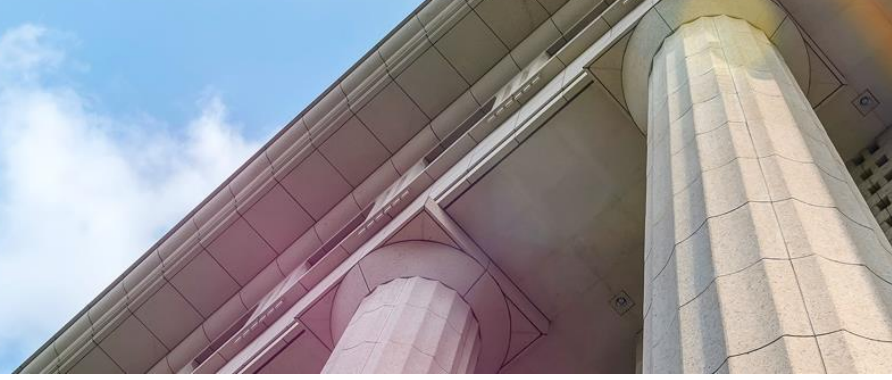

We have covered a lot of ground in some detail. We now pull back and address two fundamental questions:

Why do law enforcement officials commit misconduct that leads to convictions of innocent criminal defendants?

What can we do to reduce this sort of misconduct?

On the first question, we conclude that the most important causes of official misconduct in criminal cases are systemic: pervasive practices that permit if not encourage bad behavior; lack of the resources needed to train, supervise and conduct high quality investigations and prosecutions; and ineffective leadership by police commanders, crime lab directors and chief prosecutors. If these systemic problems are corrected, misconduct is less likely to occur-and when it does happen, more likely to be counteracted before innocent people are condemned.

On the second question, we are confident that misconduct in criminal cases can be reduced, perhaps dramatically. It has already happened for a few types of misconduct, as we've seen in the preceding section-but that is no guarantee of further progress, especially since misconduct has also increased in some contexts in the last two decades.

We discuss several categories of reforms that address the varieties of misconduct we have examined. All have been tried, at least in part, and all will improve the operation of the criminal justice system beyond reducing false convictions. Misconduct that leads to convictions of innocent defendants also does harm in other cases. Guilty defendants are deprived of their rights, and innocent defendants who are not ultimately convicted are arrested and chargedthey must defend themselves, and may held in custody for long periods. In addition, changes that prevent this sort of misconduct will also reduce other poor practices that can lead to errors. Reforms that prevent misconduct that sends innocent people to prison will benefit criminal justice across the board. 


\section{WHY DO LAW ENFORCEMENT OFFICIALS COMMIT MISCONDUCT?}

Let's start with a few striking examples.

\section{a. Ken Anderson - Routine Practice}

A quick review: 239 In 1987, when Ken Anderson was District Attorney of Williamson County, Texas, he successfully prosecuted Michael Morton for murdering his wife, Christine. To do so, Anderson concealed the following evidence: neighbors had seen a suspicious stranger hanging around the Mortons' house; after the murder, while Morton was in custody, someone else attempted to use a credit card belonging to his wife and cashed a $\$ 20$ check that was in her missing purse; and the Mortons' three-year old son, who witnessed the killing, told his grandmother that "a monster" killed his mother when "Daddy was not there."

What followed was a parade of horribles. In 2011, DNA testing of a bandana found near the crime scene identified the real killer. The District Attorney's Office had successfully resisted testing that bandana for many years. Morton spent 24 years in prison for a crime that he did not commit-a crime that was itself an unspeakable tragedy for him and his family. The real killer went on to bludgeon another woman to death in 1988. Anderson himself was disgraced. He pled guilty to contempt of court, spent four days in jail, was disbarred, and was forced to resign from the position he then held as a judge.

But why did Ken Anderson conceal all that evidence of Michael Morton's innocence?

We don't know. We could ask, but we wouldn't trust the answer-if any was given-and Anderson himself may no longer know, if he ever did. Still, it's worth considering the possibilities.

Did Anderson deliberately frame a man he believed to be innocent? That seems highly unlikely. It does happen, but as best we can tell it's far more common for prosecutors and police officers to lie, cheat and conceal in order to convict defendants they believe are guilty.

In this case, that may seem like a stretch: the concealed evidence of innocence would have been devastating to the prosecution's case. Anderson was an experienced prosecutor; he knew about the credit card, the check and the statement by the victim's child. Wouldn't he at least have had doubts?

Maybe, but we think probably not. There is extensive evidence that all of us, including prosecutors, have a hard time paying attention to evidence that contradicts a theory we have already adopted. ${ }^{240}$ Anderson may have known about the discordant evidence but failed to grasp its importance, or he may have found some way to dismiss it. Sloppiness, laziness and self-

239 See supra Section VII.2.b.

240 Keith A. Findley \& Barbara O'Brien, Psychological Perspectives: Cognition and Decision Making in Examining Wrongful Convictions: Stepping Back, Moving Forward. Bruce R. Acker \& Allison D. Redlich, eds., Carolina Academic Press, 2014; Barbara O'Brien, A Recipe for Bias: An Empirical Look at the Interplay between Institutional Incentives and Bounded Rationality in Prosecutorial Decision Making, 74 Mo. L. Rev. 999 (2009); Keith A. Findley \& Michael Scott, The Multiple Dimensions of Tunnel Vision in Criminal Cases, 2006 Wisconsin Law Review 291. 
deception are ubiquitous and powerful. Plus, in most cases prosecutors are right: suspects arrested by the police are usually guilty. Like anybody else, they can make the disastrous mistake of confusing usually right with always right.

That account, however-if true-only explains why Anderson probably believed, in the face of strong evidence to the contrary, that Morton bludgeoned his wife to death. It does not explain why he broke the rules so flagrantly in order to convict him.

It may be that Anderson concealed critical evidence of innocence for reasons peculiar to the murder of Christine Morton. Perhaps he was deeply concerned to get a conviction because the case had attracted a great deal of attention. Our best bet, however, is the opposite. We think it's more likely that he concealed inconvenient evidence in Morton's case because he did it all the time, because it was his routine practice.

That explanation, if true, just pushes the question back a level: Why did he do it all the time? It's tempting to wonder about Anderson's personality and motivation: Was he amoral? Cynical? Ambitious? Maybe. Most prosecutors don't routinely violate the basic rules of fair prosecution and trial, and most, we are confident, have a more reliable moral compass than Ken Anderson.

Still, the most powerful explanation for Anderson's behavior is structural. If Anderson routinely concealed exculpatory evidence, he did it because he could. Nobody and nothing stopped him, and it made his work easier. In most cases, the defendants were guilty-in many, there would have been no dispute about guilt-and the overwhelming majority pled guilty. So who would ever know? And since (he assumed) they're all guilty, what did it matter?

But Michael Morton was innocent. And how many others? We have no idea. Very few criminal defendants insist on their innocence, go to trial, and are sentenced to life imprisonment-and few innocent defendants of any sort can prove their innocence by DNA testing on available physical evidence. It took that perfect storm to bring this outrage to light; many lesser tragedies may remain hidden.

Anderson, of course, was the elected head of his office. He set policy; he set an example for his subordinates. In at least one case, his First Assistant District Attorney, Paul Womack, followed that example. In 1993, he persuaded Troy Mansfield to plead guilty to second-degree indecency with a child by threatening Mansfield with a life sentence if he went to trial. In the process, Womack concealed-among other items-this memo in the prosecution's file: "Victim will be difficult to sponsor in Court. She told me she does not remember what happened! I suggest this case be disposed of $w /$ out trial, since victim cannot testify...Spent 2 hours $w /$ this victim-will be nigh impossible to sponsor her in court. At one point, told me nothing happened, then says little boy might have [done] it (D's son)."

Mansfield was exonerated in 2016 because, in the wake of Michael Morton's exoneration, the Williamson County District Attorney's Office made its files available to defense attorneys. Mansfield served three months in jail under his plea bargain, and 10 years on probation-and he was required to register as a sex offender for life. Because of that last provision, his case was still active in 2016. Otherwise, he probably would never have been exonerated. 
After the exoneration, Paul Womack agreed with the state bar that his license to practice law be suspended indefinitely, because of an unspecified disability. ${ }^{241}$

\section{b. Richard M. Daley - Encouraging Brutality}

On January 21, 2011, former Chicago Police Commander Jon Burge was sentenced to four and a half years in federal prison for perjury and obstruction of justice because he lied under oath about his use of torture to extract confessions from numerous criminal suspects, overwhelmingly Black men.

It's hard to summarize the enormity of the harm Burge and his underlings inflicted on those men, their families and friends, and the City of Chicago. But they didn't do it on their own. What follows, from an article by Natalie Y. Moore published by The Marshall Project, ${ }^{242}$ barely scratches the surface.

"[Burge] tortured his first documented victim in 1973. ... His officers had arrested a man named Anthony Holmes on suspicion of murder and wanted him to identify an accomplice. When Holmes refused, the officers left him handcuffed in an Area 2 investigation room and went to find Burge. A few minutes later, Burge strolled into the interrogation room with a mysterious box in a brown paper bag. The box had a hand crank on one end and two wires with alligator clamps coming out the other end. ... Burge then picked up the alligator clamps and barked, 'Nigger, you're going to tell me what I want to know.' He fastened the alligator clamps and pulled a plastic bag down over Holmes's head, warning him not to bite through it when the pain hit. Then he started turning the crank.

"When the first blast of electricity rolled through him, Holmes bit through the plastic bag-a reflex reaction that opened a vent for his screams of agony. Then everything went black, and when he woke up, Burge was putting a fresh plastic bag over his head-the terrible panic of suffocation compounded the pain of the electric shocks. ...Burge released another blast of electricity. Again Holmes felt a thousand needles piercing every nerve in his body, and they kept on piercing and piercing until his brain couldn't take it and everything went black again.

"When he woke up, Burge was laughing and preparing his infernal box-he called it 'the nigger box'-for another round. Holmes broke. He confessed to a murder he didn't commit. ...

"The torture ring was great for Burge's career. Because of his high clearance rate, he was promoted to sergeant and then lieutenant-even though he was so open

241 See Tony Plohetski, A Life of Shame: How Williamson County Prosecutors' 23-Year-Old Notes Exposed a Father's Wrongful Conviction, Austin American-Statesman, November 15, 2019.

242 Natalie Y. Moore, Payback, The Marshall Project (Oct. 30, 2018). 
about his methods that he sometimes displayed his 'nigger box' on a table at the police station." 243

In 1983, Darrell Cannon was questioned by Burge's crew, who wanted him to lead them to one "A.D.," a gang member suspected of murder. By then, Burge and the officers working under him had expanded their range of techniques. Years later, as reported by Moore, Cannon testified that they drove him to a remote spot on railroad tracks, and there:

"The officer with the pump shotgun played Russian roulette on me by showing me a shotgun shell, then turning his back to me, says, "Listen, nigger" and all I could see was his back and not the shotgun nor the shell, and I heard two clicks of the shotgun being clicked. Then he turn to face me forcing the barrel into my mouth saying, "Nigger! Are you going to tell us where A.D. is?" ,

"Cannon said he didn't know, which he didn't, but the officer with the shotgunLt. Peter Dignan, Burge's second-in-command-shoved the shotgun into his mouth again. The other officers shouted, 'Blow that nigger's head off!' like a cheering section. But Cannon still didn't know where A.D. was, so Dignan played another round of turning his back to load the shotgun and coming back around to shove it into Cannon's mouth. ..."244

When that didn't work,

"Dignan and the officer with the cattle prod-a sergeant named John Byrne, threw [Cannon] in the unofficial vehicle they'd so ominously chosen to use ....and once in the car, they pulled Cannon's pants down around his ankles, armed the cattle prod and pushed it into Cannon's crotch. When that didn't produce the answer they wanted... Byrne hit his crotch with another blast of electricity, and this time he kept it up for a solid 30 seconds.

"Cannon couldn't take any more. The torture team had broken him. He'd say anything they wanted, he begged. He'd sign any document, admit to killing the president of the United States, just please God make it stop.

"Three years later, Byrne was promoted to commander." 245 
In 1991, after these horrifying stories finally started to came out, Burge was suspended. ${ }^{246}$ In 1993, he was fired by the police department, but kept his pension. Two of his subordinates were suspended, but ultimately were fully reinstated with back pay. ${ }^{247}$

In 2009, two years before Burge was convicted of perjury, the Illinois State Legislature created a Torture Inquiry and Relief Commission, ${ }^{248}$ which eventually concluded that 32 defendants who had been convicted of felonies in Cook County presented sufficient evidence that their confessions were obtained by torture to require court hearings ${ }^{249}$-not counting many who were no longer alive, or did not file claims for other reasons, or had been tortured but did not confess, or were not convicted, or whose confessions were not used in court. In 2014 and 2015-after the United Nations Committee Against Torture condemned the City of Chicago for failing to provide sufficient redress to torture victims ${ }^{250}$-the City Council issued a formal apology to Burge's victims; provided up to $\$ 100,000$ in reparations for each victim; gave free city college tuition, job training, and psychological services to victims and their families; and required Chicago schools to teach the history of police torture in 8th and 10th grade history classes. ${ }^{251}$ By 2018 , city, county, and state taxpayers had paid at least \$132 million in settlements and legal fees for claims of torture by Burge and his men. ${ }^{252}$

Many, probably most of the men tortured under Burge were guilty of at least some of the crimes to which they confessed. But 19 exonerations in the Registry were from convictions based on false confessions obtained by Burge and his officers, one rape and 18 murder cases, including four death sentences.

Burge and his men committed countless premeditated violent crimes against helpless people in their custody. They were vicious, sadistic and racist. There is no point in exploring their motives. Such people exist, some become police officers; some corrupt their colleagues. The glaring question is different:

How did they get away with it for so long, with impunity?

Dozens, probably hundreds of people must have known about what they were up to, at least in one or a few particular cases: other police officers, sheriff's deputies at the county jail, medical

246 David Jackson, Questions About Police Torture Persist, Chicago Tribune, Nov. 11, 1991.

247 Demoted Detectives Win Reinstatement, Chicago Tribune, Jan. 28, 1994. For a detailed history of Burge's legacy of police torture and its impact on Chicago, see Flint Taylor, The torture Machine: Racism and Police Violence in Chicago (2019).

248 Illinois Torture Inquiry and Relief Commission Act, 775 III. Comp. Stat. 40 (2009).

249 State of Illinois Torture Inquiry and Relief Commission, TIRC Decisions. The TIRC decisions by outcome are listed here.

250 People's Law Office, “UN Committee Against Torture Calls Out the US Government."

251 Chicago City Council, Anti-Torture Resolution (2015).

252 Elvia Malagon, 4 Things: The Cost of Jon Burge’s Police Torture Legacy, Chicago Tribune, Sept. 21, 2018. 
personnel, prosecutors and their investigators, and probably some judges. Didn't anybody alert someone with the authority to stop this reign of torture and bring the torturers to account?

Actually, that did happen-probably many times, but at least once that is well documented.

On February 17, 1982, Dr. John Raba, Medical Director of the Cook County Jail hospital, sent a letter to the Superintendent of the Chicago Police Department concerning Andrew Wilson, who had been arrested by Burge and his officers for killing two police officers.

"I examined Mr. Andrew Wilson on February 15 \& 16, 1982. He had multiple bruises, swelling, and abrasions on his face and head. His right eye was battered and has a superficial laceration. [He] had several linear blisters on his right thigh, right cheek and anterior chest which were consistent with radiator burns. ... He also stated that electrical shocks had been administered to his gums, lips, and genitals.

"All these injuries occurred before his arrival at the Jail.

“There must be a thorough investigation of this alleged brutality."253

A week later, the Superintendent wrote to Richard M. Daley, State's Attorney for Cook County from 1980 to 1989 when he became Mayor of Chicago, transmitting Dr. Raba's letter and adding that "because the person in question" was a defendant in a criminal prosecution by Daley's office, "I will forebear from taking any steps ... until I hear from you or one of your assistants."254

And that was where it ended.

In June 2006, then-Mayor Daley gave a sworn statement about that letter to a special prosecutor investigating the Burge torture regime. It's a rambling account in which Daley basically says several times that he was not responsible for the inaction-although he admitted that he must have seen the letter-because it should have been handled by his subordinates.

In 2008, asked if he would apologize for the torture by Burge and those working for him, Daley said, sarcastically:

"The best way is to say, 'Okay. I apologize to everybody [for] whatever happened to anybody in the city of Chicago.'... So, I apologize to everybody. Whatever happened to them in the city of Chicago in the past, I apologize. I didn't do it, but somebody else did it. ..." Daley said, laughing. ... "But I was not the mayor [at that time]. I was not the police chief. I did not promote [Burge]...." 255

True. Daley was just the prosecutor who used confessions Burge extracted by torture instead of prosecuting the torturers. It was an open secret in the Chicago Police Department that Daley

253 Letter from Dr. John M. Raba, Medical Director, Cermak Prison Health Services, to Richard J. Brzeczek, Superintendent, Chicago Police Department (Feb. 17, 1982).

254 Letter from Richard J. Brzeczek, Superintendent, Chicago Police Department, to Richard M. Daley, State's Attorney, Cook County (Feb. 25, 1982).

255 Daley Sarcastic About Burge Torture, Chicago Sun-Times, Nov. 23, 2008. 
and his deputies knew of the torture and tacitly condoned it. ${ }^{256}$ And, of course, so did the command structure of the Chicago Police Department.

Why did Daley and Burge's superiors in the police department tolerate if not encourage this reign of terror? The simplest answer is probably the best: they thought the defendants were guilty, they wanted murder convictions, and they didn't worry about the means. Plus they probably didn't mind the infliction of torture on men they believed were murderers-at least not when those men were Black.

So torture became routine. Not in all cases, or most-not even in most murder prosecutionsbut if a confession was needed to close a case and the suspect wouldn't confess, Burge and his men went to work. And it wasn't just them. They may have been the most notorious and systematic torturers; they may have led the way; but they were not alone. Once it became clear that torture was permitted, why wouldn't other officers join in? Not all, probably not most, but more than a few. As we saw, there were 52 exonerations with false confessions produced by violent interrogations in Chicago. ${ }^{257}$ Fewer than half were conducted by officers in Burge's unit; 13 occurred after he was fired.

\section{c. Joyce Gilchrist - Rewarding Fraud}

On May 8, 1985, a woman was raped in her apartment complex in Oklahoma City. Jeffrey Pierce, who worked at the complex as a landscaper, was taken by police to the victim; she said he was not the rapist. In 1986, police created a photographic lineup with a picture of Pierce wearing a tan shirt-an element of the victim's initial description of her attacker-and the victim identified him. ${ }^{25}$ Pierce was arrested, convicted of rape and related crimes, and sentenced to 65 years in prison. He was exonerated by DNA testing 15 years later, in 2001. Pierce's conviction depended heavily on the testimony of Joyce Gilchrist, a forensic chemist at the Oklahoma City Police Department.

Gilchrist testified that 33 scalp and pubic hair samples from the crime scene were "microscopically consistent" with hairs taken from Mr. Pierce's body. In other words, she testified that the hairs could have come from Mr. Pierce. Such testimony is scientifically meaningless because there are no systematic data on the frequency of various microscopic characteristics in human hair- even if the two hair samples do in fact share similar characteristics. In this case, that basic factual premise was false. A re-examination by the FBI in 2001 "concluded that none of the hairs taken from [Pierce's] body exhibited the same microscopic characteristics as those found at the crime scene." 259 In other words, Gilchrist

\footnotetext{
256 See generally Flint Taylor, The Torture Machine: Racism and Police Violence in Chicago (2019).

257 See supra, Section V(3)(a)(i); Klara Stephens, Misconduct and Bad Practices in False Confessions: Interrogations in the Context of Exonerations, 11 Northeastern Univ. L. Rev. 593, 607 (2019).

258 Pierce v. Gilchrist, 359 F.3d 1279 (10th Cir. 2004).

259 ld. at 1283.
} 
concealed the fact that the hairs found at the crime scene could not have come from Pierce's body.

In addition, Gilchrist violated a court order to deliver the hair samples in a timely manner for review by Pierce's own expert. And, most important, Gilchrist concealed her own findings that Pierce could not have been the rapist because his blood contained an enzyme that was absent from the semen found in the victim. ${ }^{260}$

This was hardly the only case in which Gilchrist committed forensic fraud. The 2001 FBI review "found that at least five of the cases involved contrived and erroneous statements by Ms.

Gilchrist." ${ }^{261}$ And in the case of Alfred Brian Mitchell, a federal judge found that Gilchrist knew that "testing [by the FBI] revealed that [Mitchell's] DNA was not present on the samples" of semen taken from the victim-but lied and testified that "the DNA analysis performed by the FBI was "inconclusive."”262 A Federal Court of Appeals concluded on review that "Ms. Gilchrist thus provided the jury with evidence implicating [Mitchell] in the sexual assault of the victim which she knew was rendered false and misleading by evidence [that she] withheld from the defense." 263

Ultimately, hundreds of Gilchrist's cases were reviewed. Six defendants she testified against have been exonerated, including two who were sentenced to death, and others are still disputed. In one of those death row exonerations, Gilchrist erroneously concluded that the real killer could not have been involved because he had the wrong blood type. And in a rape-murder in Beatrice, Nebraska, in 1985, an initial suspect-the real killer-moved to Oklahoma City shortly after the crime, where Gilchrest obtained a blood sample and reported the wrong blood type. As a result, he was falsely cleared. That led to a four-year investigation that produced false convictions of six innocent defendants, who were ultimately exonerated in 2008 and 2009 after DNA evidence proved the crime was committed by the suspect Gilchrist had cleared in 1985 .

Why did Joyce Gilchrist embark on this career of systematic fraud and at least occasional incompetence? We can only guess at her motivation, but the effect was unambiguous. She became a star. After Pierce was convicted in 1986, Gilchrist received an honorary citation from the Oklahoma City police and a commendation from the district attorney, for her "skillful work in the careful analysis of the forensic evidence." ${ }^{264}$ In 1990, she was promoted to supervisor,

260 Id. at 1282.

261 Id. at 1283.

262 Mitchell v. Ward, 150 F. Supp. 2d 1194, 1226 (W.D. Okla.1999).

263 Mitchell v. Gibson, 262 F.3d 1036, 1064 (10th Cir. 2001). Mitchell was sentenced to death for murder; the alleged sexual assault on the victim was presented to the jury as an aggravating factor to consider in deciding whether to sentence him to death. Gilchrist's misrepresentations on that issue led the court to vacate Mitchell's death sentence, but not his murder conviction.

264 David Kohn, Under the Microscope: Forensic Scientist Accused of Mishandling Cases, CBS: 60 Minutes (May 8, 2001).

Government Misconduct and Convicting the Innocent The Role of Prosecutors, Police and Other Law Enforcement

Page $141 \cdot$ National Registry of Exonerations • September 1, 2020 
years earlier than usual. In 1995, she was named Oklahoma City Police Department Civilian Police Employee of the Year. ${ }^{265}$

Gilchrist's work made her popular with police officers. She became known to them as Black Magic "because she was able to get results that no other chemist could. When ... homicide detectives gave Gilchrist hair samples from a suspect, they would often let her know that this was the person that they wanted to arrest." ${ }^{266}$ Some later claimed that they "didn't believe Gilchrist was doing proper lab work, because her results were 'too good"'-but that didn't stop them from using those results in court. ${ }^{267}$

Gilchrist was also a forceful and effective witness, and prosecutors came to rely on her to win difficult jury trials. In some cases, they committed misconduct themselves in presenting her evidence. Alfred Brian Mitchell's trial was a striking case, as a federal court described in 2001: "Compounding [Gilchrist's] improper conduct was that of the prosecutor, whom the district court found had 'labored extensively at trial to obscure the true DNA test results [which cleared Mitchell of rape] and to highlight Gilchrist's [misleading] test results...."268

Gilchrist became a particular favorite of Oklahoma County District Attorney Bob Macy. In February 2001, Gilchrist, who was being investigated by the police department, was placed on administrative leave. In June 2001 Macy resigned unexpectedly, saying he wanted to spend more time with his family. Three months later, Gilchrist was fired.269

There had been warnings, for years. Defense attorneys had complained about Gilchrist. John Wilson, chief chemist at the Kansas City police crime laboratory, testified for the defense in several cases that Gilchrist worked on; in 1987, he filed a complaint against her with the Southwestern Association of Forensic Scientists. ${ }^{270}$ In 2001, after his claims were confirmed by the FBI, Wilson said:

"I think you have to look at the prosecutor's office ... they have to understand what's been going on. They have to have seen all the flags that have been waved. The judges are no different. ... It's not just the police, it's not just the prosecutors, it's everyone in the entire system.”271

But as long as the engine was humming along, nobody wanted to look under the hood.

\footnotetext{
265 Belinda Luscombe, When the Evidence Lies, Time (May 13, 2001).

266 Mark Fuhrman, Death and Justice: An Expose of Oklahoma's Death Row Machine 91 (2003).

267 Id. at 71.

268 Mitchell, 262 F.3d at 1064.

269 Lois Romano, Police Chemist's Missteps Cause Okla. Scandal, Wash. Post (Nov. 26, 2001). See generally Daniel LaChance, Executing Freedom: The Cultural Life of Capital Punishment in the United States (2016), ch. 6.

270 Paul C. Giannelli, Scientific Fraud, 46 Criminal Law Bulletin, 1313, 1325 (2010).

271 See David Kohn, Under the Microscope: Forensic Scientist Accused of Mishandling Cases, CBS: 60 Minutes (May 8, 2001). See also Scott Cooper, Former DA Bob Macy, ex-forensic chemist Joyce Gilchrist settle case, The Oklahoma Gazette, June 18, 2009.
} 
d. Officers Iannotto, Palmer, Pecorale, Martin, Visconti and Bishop, and Detective Massanova - Closing Cases

Around 2 a.m. on the morning of November 18, 1990, a young man in a group of several bumped into another youth in a different group on a street in Greenwich Village in New York City. One of the two who collided was wearing a reversible "orange aviator-style jacket." He produced a .32 caliber pistol and fired repeatedly at the walls of nearby buildings. He then handed the gun to a companion, who fired at the opposing group, killing one man and seriously injuring another. The shooters ran away, followed by one of those they had shot at-Jose Fontanez-who flagged down a police car.

Officers Glenn Iannotto and Drew Palmer drove to a nearby train station to intercept the suspects if they tried to escape by train. They were joined there by officers Dean Pecorale and Jill Martin, who spotted Luis Rojas on a train about to leave the station, wearing a jacket similar to the one worn by the man who produced the gun, but with the orange shell on the inside and the reversible maroon side was on the outside. Rojas was taken off the train, instructed to turn his jacket inside out so the orange shell was on the outside, and handcuffed. In the meantime, Officers Visconti and Bishop brought Fontanez to the station, where he identified Rojas as the man who fired the first shots.

Shortly after that, officers Pecorale and Martin took Rojas to the scene of the shooting, and officers Bishop and Visconti drove Fontanez there as well. An appellate court, reviewing the case several years later, described what followed:

"All but three of the youths who were shot at ... testified at trial that they were at the crime scene when defendant arrived, handcuffed, in the back of the patrol car. Defendant testified... that Mr. Fontanez, in front of other witnesses, pointed at him through the cruiser's window saying that he was the one because ' $[\mathrm{h}] \mathrm{e}$ has the colors on.' At some point, [one of the men who had been shot at-all of whom had been drinking] began punching the car and was restrained by the officers present at the scene." ${ }^{72}$

The following morning, Detective Daniel Massanova conducted a lineup that was seriously compromised. It consisted of Rojas himself and several "police cadet fillers who all had short hair ... were neat, fresh and clean-shaven with crew cuts, as they were on their way to the [Police] Academy, while the suspect had been up all night before the 10:20 A.M. lineup, so the cadets were easily identified."273

Needless to say, Rojas was once again identified repeatedly as the man who started the shooting. On February 26, 1992, he was convicted of second degree murder and related offenses, and was sentenced to 15 years to life in prison. Six years later, Rojas was exonerated by overwhelming evidence that he had been misidentified.

272 People v. Rojas, 213 A.D.2d 56, 630 N.Y.S.2d 28 (N.Y. App. Div. 1995); the Rojas opinion included a detailed description of this case.

273 ld. 
In a 1995 opinion reversing Rojas's conviction, the Appellate Division of the New York Supreme Court wrote:

"Once the identification and arrest had been made, there was no need for an on-thescene investigatory showup and defendant should have been kept segregated from the potential lineup witnesses. Instead, as demonstrated by the officers' radio transmissions, defendant was intentionally... returned for additional showups.

"This on-the-scene showup was further tainted by the fact that Fontanez was also returned to the crime scene and ...[said] in front of other witnesses, while pointing to defendant that he was the one because '[h]e has the colors on'....

"The lineup itself approaches the bizarre. [T] he fillers were police cadets, clean shaven, crew-cut and neat on the way to the Academy after a good night's sleep [while the suspect] had 'normal' length hair, had been up all night and [was], no doubt, disheveled, probably looking the worse for wear." 274

In short, as the court concluded:

"The entire identification procedure, or rather the series of identifications were both improper and prejudicial." 275

This too was routine misconduct, if not in the same range as Ken Anderson's or Richard Daley's. The police officers responded quickly to the scene of a murder, located a plausible suspect-and then went off the rails. From the look of it, they were convinced that they had the shooter and knew they needed eyewitness identifications, so they went about getting those identifications in the easiest manner possible without considering the possibility that they were orchestrating the conviction of an innocent man.

\section{CAN WE REDUCE OFFICIAL MISCONDUCT IN CRIMINAL CASES?}

Yes, we can reduce official misconduct in criminal cases. It has happened. There have been dramatic reductions in some types of misconduct among exonerations involving convictions since 2003, and even greater improvements in the middle decades of the twentieth century. But misconduct that leads to false convictions could also get worse; we've seen that too, in some settings.

There is no panacea for official misconduct in criminal prosecutions because it's not one thing but several different types of behavior, by different actors in different settings. A single remedy is no more likely than a general cure for "disease."

In this section, we discuss several categories of reforms, some of which may have already produced favorable changes. We start with the most specific-rules that dictate the conduct of

\footnotetext{
274 ld.

275 ld.
} 
law enforcement officials-and proceed to the most general, changes in our legal and political culture.

\section{a. Categories of Reforms}

i. Rules

\section{(a) Procedural rules}

Michael Morton was convicted of a murder he did not commit because his prosecutor, Ken Anderson, deliberately concealed powerful exculpatory evidence. In 2013, in response to his exoneration, the Texas Legislature passed and the governor signed the Michael Morton Act, which created "open file" discovery in criminal cases in Texas. ${ }^{276}$ It requires prosecutors to provide defendants with copies of, or access to:

"[A]ny offense reports, any designated documents, papers, written or recorded statements of the defendant or a witness, including witness statements of law enforcement ... or any designated books, accounts, letters, photographs, or objects or other tangible things ... that constitute or contain evidence material to any matter involved in the action and that are in the possession, custody, or control of the state...."

The Act also addresses the specific duty that Anderson violated. It provides that "the state shall disclose to the defendant any exculpatory, impeachment, or mitigating document, item, or information in the possession, custody, or control of the state that tends to negate the guilt of the defendant or would tend to reduce the punishment for the offense charged." 277 That provision was not new; it reiterated existing constitutional and ethical requirements.

Anderson, of course, broke existing rules by concealing exculpatory evidence. Not only did he violate Morton's right to due process of law, he also lied to the judge who presided over the case when he falsely claimed to have provided him with all potentially exculpatory evidence.

Would this sort of general procedural rule have made a difference to Morton's prosecution in 1987? Maybe. If you're required to disclose everything, it may be harder to hide the evidence you'd hate to face in court. Where open discovery becomes the rule, defense attorneys and judges may become better at spotting gaps and omissions, and prosecutors may become more wary of holding back critical information.

The key, of course, is enforcement. We think it's likely that Ken Anderson ignored fundamental rules in Michael Morton's case because they were unenforced and ignored by prosecutors in Williamson County generally. That can happen to any rule, from those that require open discovery in criminal cases to those that prohibit speeding, tax evasion, or the murder of civilians in war zones. Every type of misconduct we discuss violates existing legal and ethical rules. Why not just enforce those that we already have?

\footnotetext{
276 Texas Code of Criminal Procedure, Art. 39.14.

277 Id.
} 
Strict enforcement of existing rules may work as well as anything-if it happens. New rules can make enforcement more likely by mobilizing support and drawing attention to the problem, especially if they specify what should be done in concrete terms. In November 2017, for example, the Chief Judge of the State of New York "announced the adoption of new rules that will require judges presiding over criminal trials to issue an order notifying and reminding prosecutors" in detail of their obligation to disclose exculpatory evidence. ${ }^{278}$ The announcement specifically notes that "the new order... does not in any way change existing law, [but] provides a mechanism by which to educate inexperienced prosecutors and defense attorneys-and remind experienced ones-about their constitutional and ethical duties." 279 This new rule could make a major difference, if implemented and taken seriously, or it could become an empty formality.

Prosecutors and police can only conceal evidence they have obtained in the process of investigation. The "procedural" rules of discovery that bear on this sort of misconduct govern the disclosure and use of information that is already in the hands of state officers. The same is true for prosecutorial misconduct at trial, which is governed by elaborate procedural rules of evidence and trial practice.

On the other hand, there are several contexts in which specific rules on how to obtain and preserve evidence could improve the quality of information in criminal trials generally, and reduce misconduct along the way.

\section{(b) Evidence gathering rules}

Eyewitness identification. In People v. Rojas, ${ }^{280}$ the Appellate Division of the New York Supreme Court had many complaints about the lineup that Detective Massanova used to obtain identifications of the defendant, including this: "Since no lineup photos were taken ... appellate review, to a large extent, [is] speculation." ${ }^{281}$ It would have been better if Massanova had photographed the lineup, and better yet if he had recorded the entire process on video.

Failing to photograph or record a lineup is common, and it's not misconduct. But if there had been a rule that required the police to photograph the lineup (there was no such requirement), it might have prevented the misconduct that did occur: subjecting Rojas to a patently suggestive procedure that was guaranteed to produce identifications whether he was guilty or not. Photographing lineups reduces the incentive to deliberately cook an identification because it makes (at least some forms of) suggestiveness visible for all to see later on. It may also reduce the likelihood of unintentional suggestiveness by focusing attention on the procedure and

\footnotetext{
278 Press Release, N.Y. State Unified Court System, Chief Judge DiFiore Announces Implementation of New Measure Aimed at Enhancing the Delivery of Justice in Criminal Cases (Nov. 8, 2017). The new rules specifically say that the "order [from the trial court] shall not contain any reference to materiality," and include provisions that require trial courts to remind defense attorneys in detail of their duty to provide criminal defendants effective legal representation.

279 ld.

280 People v. Rojas, 213 A.D.2d 56, 630 N.Y.S.2d 28 (N.Y. App. Div. 1995) (N.Y. App. Div. 1995).

281 Id., 213 A.D.2d at 70.
} 
reminding the officer who administers a lineup that others will review it. And, of course, it makes it easier for judges and juries to assess the value of an identification after the fact.

Recording the identification process is one of several rules that have been proposed, and sometimes adopted, for the purpose of increasing the accuracy of eyewitness identifications. Others include: having the lineup administered by a person who does not know the identity of the suspect, and therefore cannot communicate it to the witnesses, purposefully or inadvertently; selecting "fillers" for the lineup who resemble the witnesses description of the criminal; telling each witness that the criminal may or may not be in the lineup; recording the level of confidence of any witness makes an identification; and never permitting multiple witnesses to view a lineup together. ${ }^{282}$

These procedures are designed to make all misidentifications less likely-including those that might be generated by "tainted identification procedures" in which "police intentionally structure the identification to induce the witness to identify the exonerees." 283 They keep police from deliberately stacking lineups by requiring them to run lineups that can't be stacked. At least that's the theory.

Similar rules have been proposed, and sometimes enacted, to govern other aspects of criminal investigations. The most important are those that require that interrogations of criminal suspects be recorded, preferably on video.

Interrogations. As we have noted, much of the coercive behavior that produces false confessions is not considered misconduct. ${ }^{284}$ Officers are allowed to question suspects in isolation and at great length, to tell them that their guilt has been determined beyond doubt, and to lie to them about physical evidence ("we have your fingerprints") or other witnesses ("your buddy already told us you did it"). Sometimes, this behavior spills over into misconduct; often, it does not.

If a defendant's guilt is in dispute despite his confession, it's essential to know what actually happened in the interrogation-in some cases, to decide whether a confession by the defendant must be excluded from evidence because it was coerced; in others, to evaluate the credibility of a confession that has been admitted.

But in many cases-until recently, almost all-we don't know what happened in the interrogations because they were not recorded in any form. The Supreme Court described the issue 75 years ago, when E. E. Ashcroft claimed that he was forced to confess during a long interrogation by the Memphis police:

"As to what happened ... during this thirty-six hour secret examination, the testimony follows the usual pattern, and is in hopeless conflict. Ashcraft swears that the first thing said to him when he was taken into custody was, 'Why in hell did you kill your wife?'; that, during the course of the examination, he was threatened and abused in various

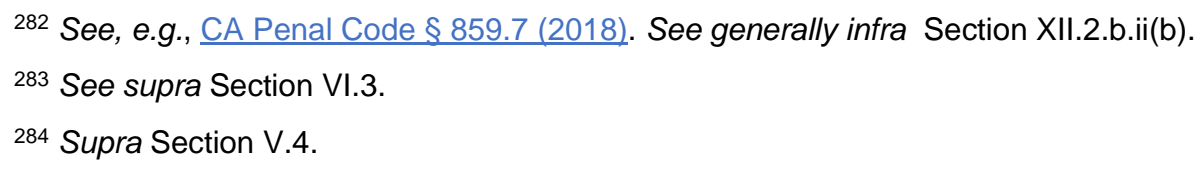


ways, and that, as the hours passed, his eyes became blinded by a powerful electric light, his body became weary, and the strain on his nerves became unbearable. The officers, on the other hand, swear that, throughout the questioning, they were kind and considerate. ${ }^{285}$

In the last 30 years, exonerations by DNA and other means have proven beyond doubt that false confessions occur on a regular basis, especially in murder cases. In response, there has been a growing movement to require that interrogations be recorded, in all felony cases or at least in homicides. In 2000, recording interrogations was required in two states, and explicitly frowned upon by federal law enforcement agencies. It is now required, in some form, by 26 states, the District of Columbia and all agencies of the United States Department of Justice. ${ }^{286}$

Needless to say, recorded interrogations are far less likely than unrecorded ones to include misconduct of any sort-and will probably never include torture. That connection is not incidental. One of the turning points in the spread of this reform occurred in 2003, when Illinois passed a law that requires police to record interrogations in murder cases-a law that was an explicit response to the horrific history of torture by Jon Burge and his lackeys. ${ }^{287}$

Witness interviews. Eyewitness identification and interrogation are two major contexts in which police deal with potential witnesses. A true confession, like an accurate identification, is factual evidence from a "witness" to the crime. Rules that require recording these procedures make it easier to tell if a suspect confessed to a crime he did not commit-or a witness identified a suspect she did not see-and also discourage misconduct that may produce false confessions and erroneous identifications. Conceptually, however, these are specific applications of a more general rule.

We could require police to record all conversations with people who are interviewed during the investigation to a crime, and to make video recordings whenever the information they seek includes visual content. If such a rule were enacted and observed, it would produce accurate information about witness statements, and along the way, prevent the worst sorts of witness tampering: the use of threats, lies, bribes or promises of favors to induce witnesses to give false evidence.

No such rule exists anywhere in the United States, but it's technologically feasible. Officers, for example, could be required to wear bodycams and to turn them on when talking to witnesses. This is, in fact, one aspect of several general police bodycam rules that have been proposed to

285 Ashcraft v. Tennessee, 322 U.S. 143 (1944) (footnotes omitted).

286 See infra XII.2.b.ii(a). The 26 states include 24 that added statutes or court rules that required recording all or some types of interrogations, and two where all police agencies in the state did so on their own.

2873705 ILCS $\$ 405 / 5-401.5$ and 725 ILCS $\S 5 / 103-2.1$, relating to investigations of first degree murder suspects (the statute took statewide effect in July 2005). See Steven Thomma, Police interrogation law showed Obama's skill in Illinois senate, McClatchy Newspapers (Impact 2020), March 27, 2008, for a description of the crucial role Barak Obama-then an Illinois state senator-played in getting that legislation passed. 
address police violence, especially as a part of the Black Lives Matter movement. ${ }^{288}$ Of course, officers who are about to commit a crime by threatening witnesses in order to procure perjury will not do it on camera, rule or no rule. But if there were such a rule, they might do it less often.

Physical evidence. Most police forces have no general rules that govern the collection and preservation of physical evidence, from fingerprints and biological trace evidence to weapons, clothing, vehicles, stolen objects, and so forth. Such rules might both improve the quality of evidence that's available at trial and make it more difficult for officials who are so inclined to conceal or destroy exculpatory physical evidence.

The rules we describe in this section are not specifically aimed at misconduct. Their main purpose is to improve criminal investigations by treating all evidence-objects and the memories of witnesses alike-as fragile material that must be carefully collected and preserved: Record what witnesses and suspects say, and the context in which they speak; avoid biasing their memories or leading them to say things they don't believe; find all available physical evidence and store it intact. Along the way, following these rules is likely to reduce misconduct, perhaps dramatically.

What possible objection could there be to these reforms? Some officers, of course, would like to continue to influence lineups, coerce confessions, or ignore physical evidence that suggests that a suspect might be innocent. That's not an argument anybody actually makes, but there are slightly more respectable relatives in the vicinity. Some police officers, for example, object to recording interrogations on the ground that jurors will not "understand" why ugly interrogation techniques are "necessary"-that it's better for them to remain ignorant of how their evidentiary sausages are made. It's a hard position to defend. If you can't explain to a jury why your method of interrogating suspects is OK, you probably shouldn't be doing it-and you certainly shouldn't be allowed to hide the process from those who decide those suspects' fates.

There is, however, a different objection to detailed rules on obtaining and preserving evidence. Implementing them takes time, money, training and supervision-in short, resources. Without adequate resources, rules like these-if adopted-will not be followed or enforced.

\section{ii. Resources}

When we described the 1992 murder conviction of Luis Rojas, we said that he was exonerated six years later "by overwhelming evidence that he had been misidentified." 289 But we didn't say what that evidence was (other than the extreme suggestiveness of the eyewitness identifications the police obtained). The new evidence of Rojas's innocence that was presented in 1998 included:

288 See, e.g., ACLU, A Model Act For Regulating the Use of Wearable Body Cameras by Law Enforcement, Version 2.1 (June 2018); Jay Stanley, Police Body-Mounted Cameras: With Right Policies in Place, A Win for All, ACLU (March 2015). See generally Shelley S. Hyland, Body-Worn Cameras in Law Enforcement Agencies, U.S. Department of Justice, Bureau of Justice Statistics (2016).

289 Supra Section XII.1.d. 
(i) An alibi from a police sergeant for the New York Port Authority, who saw Rojas at the train station 10 minutes before the city police officers arrived-which meant that he could not have participated in the shooting.

(ii) Testimony from an uninvolved eyewitness to the shooting-a security guard at a restaurant across the street-who gave the police a description of the man they were looking for, in an aviator jacket, that did not resemble Rojas. Later, when that witness saw Rojas back at the scene of the crime, handcuffed in a squad car, he told police that Rojas "was definitely the wrong man." 290 That security guard was not asked to view the lineup the next morning at which Rojas was identified by several companions of the victims who had been shot.

In other words, if the police had done a decent investigation on the night of the shooting, or in the days that followed, Rojas would never have been charged with any crime, let alone convicted of murder and imprisoned for six years. Why didn't they do a better job?

It's tempting to blame laziness or incompetence, and they may have played a role. But the work load of the New York City police department was probably a bigger factor. There were more than 2,000 homicides in New York in 1992, compared to 287 in 2018. In that unruly context, the detective in charge of the investigation probably thought the Rojas case was easy: the police caught the gunman as he was trying to escape (or so they thought), and he was immediately identified by several witnesses to the shooting. A lineup was needed to nail the lid shut-and then on to the endless line of other murder cases.

When police officers fail to conduct a careful investigation in a criminal case, the consequences may be catastrophic. In this case, they didn't interview a readily available alibi witness, and ignored a credible (and sober) eyewitness who gave them a description of the criminal that didn't fit Rojas and then told them that Rojas "definitely" didn't do it. As a result, an innocent man was convicted and imprisoned, and the actual criminals were never apprehended. In other cases, they might ignore fingerprints that are visible at the scene of a killing, or blood, or a gunwith equally disastrous results.

All the same, failure to conduct a good, or even a minimally competent, criminal investigation is not in itself "official misconduct" as we, and as courts, use the term. Misbehavior that harms another person comes in two basic varieties: abuse and neglect. "Misconduct" by law enforcement officials in a criminal case is always abuse-some form of affirmative action that breaks the rules and deprives the defendant of a legal right.

Criminal suspects and defendants have legal rights to be free from physical abuse, obstruction of justice, illegal arrests and searches, official perjury, and so on. But they have no affirmative right to high quality investigations of their cases, or indeed, to any investigation at all. Concealing exculpatory evidence violates their rights; in rare cases, so does a failure to collect or preserve evidence, but only if it is done in bad faith, which usually means that an officer deliberately

290 People v. Rojas, 213 A.D.2d 56 at 68, 630 N.Y.S.2d 28 (N.Y. App. Div. 1995). 
decided to ignore evidence that might undermine the case against a criminal defendant. ${ }^{291}$ Neglecting to do an adequate job may be just as harmful, or worse, but it is not "misconduct."

Lack of resources, however, does intersect with misconduct, in two ways:

First, the absence of a competent investigation, whatever its cause, leaves a suspect vulnerable to misconduct. That's what happened to Luis Rojas. If Detective Massanova or other officers had interviewed the Port Authority police sergeant who would have provided Rojas with an alibi, their misconduct in obtaining obviously suggestive identifications probably would not have mattered. The alibi would likely have led to further investigation, after which Rojas would have been released and the tainted identifications would not have contributed to a false conviction. That happens regularly. As best we can tell from limited data, most misidentifications of innocent suspects ${ }^{292}$-and most false confessions ${ }^{293}$-do not produce wrongful convictions, usually because other evidence that proves the suspects' innocence emerges before the case gets to trial. In Rojas's case, the other evidence was never sought, seen or heard.

Second, lack of resources may tempt officers to break the rules because they don't have the time to conduct proper investigations. That may have happened to Luis Rojas. The officers who arrested him might have intentionally set up a hopelessly tainted identification process in order to get identifications quickly and easily, and wind up the investigation within hours of the crime.

Sometimes, police officers who are overwhelmed by murder cases take a different impermissible short cut. They detain several young men or boys they find in the vicinity of a killing, interrogate them until one of them confesses or names another as the killer-and then close the case.

That seems to be what happened to Kendrick Scott and Justly Johnson, who were arrested and charged with murder within hours after Lisa Kindred was shot and killed in Detroit on May 9, 1999. Antonio Burnette and Raymond Jackson had been arrested hours earlier as part of the same investigation, and they told the police-and later testified in court-that Scott and Johnson told them that they had committed the murder.

Scott and Johnson were convicted of murder in 2000. They were exonerated in 2018 after the victim's son-who witnessed the killing at close range when he was eight years old, but was never questioned by the police, the prosecution or the defendants' lawyers-testified that he was certain that neither Scott nor Johnson was the gunman. In addition, a cousin of Jackson's testified that before he died in 2008, Jackson told her that he had lied because he was afraid of the police and the prosecution; and Burnette testified that the police "whooped" him during his

291 See Arizona v. Youngblood, 488 U.S. 51, 58 (1988) ("We therefore hold that unless a criminal defendant can show bad faith on the part of the police, failure to preserve potentially useful evidence does not constitute a denial of due process of law.").

292 Samuel R. Gross, "Loss of Innocence: Eyewitness Identification and Proof of Guilt." J. Legal Stud. 16 (1987): $395-$ 453.

293 Steven A. Drizin \& Richard A. Leo, The Problem of False Confessions in the Post-DNA World, 82 N.C. L. Rev. 891, 951 (2004). 
interrogation, that he believed they considered Johnson a suspect, and that he was afraid he would be charged with the murder himself if he did not say what the police wanted to hear.

The resource we've focused on so far is time, which is inversely proportional to the number of cases each officer must handle. Resources may also be structural. It might have helped in the Rojas case if the police department had explicit protocols that required detectives, at least in homicide cases, to interview all possible alibi witnesses, construct lineups with foils who resemble the description of the criminal, and present lineups to all known eyewitnesses, not just those who have already identified their suspect. Of course, it takes time and money to devise and enforce such protocols, train the officers involved, and provide the support they need. But funding alone is not enough. It also takes expertise, commitment, and leadership.

One reason for the comparatively low rate of police misconduct among federal exonerations may be that most federal law enforcement agencies have considerably greater financial and organizational resources than most state and local police forces: fewer cases per officer, better training and equipment, more detailed record keeping and closer supervision. If true, this means that federal officers have fewer incentives to commit misconduct because they have the wherewithal to work cases properly, more opportunities to correct initial errors and avoid erroneous convictions, and more reason to fear that misconduct will be detected.

One last point: Defense resources are as important as those that are available to police and prosecutors.

Luis Rojas's conviction was not reversed on appeal because of misconduct of the police, but because the appellate court found misconduct by his defense lawyer:

"Defendant's trial counsel, Mr. Fronefield, not only made no effort to investigate the foregoing evidence [of Rojas's innocence] or defendant's alibi, but further committed numerous errors during the course of the trial which tended to implicate defendant rather than to prove his innocence. ..."294

"Mr. Fronefield's performance... deprived defendant of the effective assistance of counsel requiring reversal of the conviction." 295

It's hard to fathom the magnitude of Fronefield's incompetence in representing Rojas. Not only did he fail to interview witnesses who would have cleared his client, he went out of his way to discredit Rojas's own defense. At trial, Rojas testified, truthfully, that he was not at the scene of the shooting. That did not stop his defense attorney from arguing to the jury that Rojas actually was there, and that he had a gun. As the appellate court noted, "[it] almost appears, at times, that Mr. Fronefield acted as a second prosecutor." 296

294 People v. Rojas, 213 A.D.2d 56 at 66, 630 N.Y.S.2d 28 (N.Y. App. Div. 1995).

295 Id. at 69-70.

296 Id. at 69. 
Ineffective assistance of defense counsel is misconduct. In most cases, the defendant is deprived of his constitutional right to effective representation by neglect rather than abuse, usually by the lawyer's failure to investigate and prepare for trial. Whatever its form, however, ineffective assistance of counsel is not official misconduct. It's not covered by this Report-although, as we've said, it may do as much to generate false convictions as official misconduct, if not more.297

There's no justification for the abysmal representation Mr. Rojas received, regardless of circumstances. Across cases, however, the level of funding for indigent criminal defense has a huge impact on the quality of work defense attorneys do.

Attorney Fronefield tried to persuade Luis Rojas to plead guilty to whatever charges and sentence the prosecution offered, in a murder case that Fronefield had not bothered to investigate. Rojas refused, probably because he would have had to spend years if not decades in prison if he had pled guilty. But overworked and underpaid public defenders and private defense attorneys do persuade defendants to plead guilty every business day of the year, by the hundreds and thousands, in cases the attorneys know very little about. Usually the defendants are not charged with killing anybody, and the penalties are much lower than what Rojas faced. Some of those defendants are victims of official misconduct, and some are innocent. We rarely hear about either group.

On the other hand, effective defense attorneys reduce both the frequency and the impact of misconduct by government officials. They may deter misconduct. Police officers, prosecutors and forensic analysts may be less likely to break rules if they believe that hard-working defense lawyers are likely catch them. And good defense work can certainly prevent misconduct from producing convictions of innocent defendants. That's what should have happened to Luis Rojas, if he had not had the misfortune to be assigned a defense lawyer who "acted as a second prosecutor," and a lazy one at that.

In general, a well-staffed and well-funded criminal justice system-from police investigators and forensic analysists, to prosecutors and defense attorneys, to trial judges - is likely to see less misconduct, and the misconduct that does occur is more likely to be caught somewhere along the way before the worst happens. It can take the failure of a village to convict an innocent person.

\section{iii. Accountability}

What about punishing those who commit misconduct? Will that keep others from doing it in the future?

We know that some sort of discipline was imposed on at least one government official in about a sixth of exonerations with known official misconduct $(219 / 1,295)$. Did holding officials accountable for misconduct in those cases have any impact on misconduct by other officials?

It seems unlikely the disciplinary actions we know about had any major impact on misconduct in later cases. Discipline is uncommon-in $83 \%$ of cases with misconduct no discipline was

297 See supra Section II.2.b.

Government Misconduct and Convicting the Innocent The Role of Prosecutors, Police and Other Law Enforcement

Page 153 • National Registry of Exonerations • September 1, 2020 
imposed-and very slow: the average time from conviction to exoneration in a case with official misconduct is about 11 years. And there are conspicuous counter examples.

In 1993, when Commander Jon Burge was finally fired by the Chicago Police Department, the most prolific known torturer on the Chicago police force who was not associated with Burge was just getting started. Detective Reynaldo Guevara used beating, torture and threats to coerce false confessions and to force witnesses to lie and implicate innocent defendants. He was responsible for the false convictions in 14 murder exonerations; all but two of them occurred after Burge was fired. And Chicago Police Detective Kriston Kato was responsible for abusing numerous suspects, including two defendants who were beaten into false confessions, one for murder and one for sexual assault, and later exonerated. Both of those exonerees were wrongly convicted after Burge was fired.

On the other hand, disciplining brazen, active offenders is an essential component of any attempt to stop misconduct. The impunity that Burge and his cronies enjoyed for decades helped generate and preserve the culture of violence in interrogations in Chicago. Punishing officers who are widely known to torture suspects may not be enough to stop it from happening, but failing to do so will doom other efforts, if there are any. In fact, as we've seen, eventuallyyears after Burge was fired-the rates of abusive interrogations and false confessions in Chicago did fall to a fraction of what they were in his heyday.

Discipline comes in many flavors. The most severe is criminal conviction, which will prevent the official involved from committing any additional misconduct because he will be fired and probably imprisoned. But will it deter others from doing the same? By the time an officer is convicted of criminal misconduct, other likeminded officials will have been getting away with similar misconduct for years. Perhaps they will change their ways and hope they don't get prosecuted for past misdeeds; perhaps others will be deterred from taking up abuse and deception; but at best this is a slow and inefficient way to promote law abiding behavior.

Immediate and mild sanctions for low level infractions by the agencies for which the officials work are likely to do more to shape behavior than swinging an axe when an egregious act is discovered years later. Reprimands from supervisors for failing to follow departmental protocols on eyewitness lineups-or for failing to provide exculpatory impeachment evidence to the defense-are cheap and quick and may change the behavior of the officials involved immediately. Any action in response to an exoneration means, on average, a 10-year delay or longer, by which time the officials involved may have done the same thing many more times, or retired, or both. If the sanctions are severe, the process of imposing them may take years more.

In other words, the most effective sanctions are aspects of ongoing supervision of the officials who investigate and prosecute criminal cases. That's the stage at which misconduct is easiest to detect and prevent. That type of supervision is best done when these investigations and prosecutions are subject to explicit rules, and when the agencies involved have sufficient resources to conduct careful supervision-two categories of reform we have already discussed.

Of course, even with adequate resources, many government agencies are reluctant to discipline or even investigate their employees. It can damage morale, disrupt relations with other agencies and make the agency and its leaders look bad. The officials under scrutiny may be well-liked and well-connected. Their superiors may actually support their misconduct, and they may have other 
powerful allies-especially if they are members of police unions. Effective oversight depends on the priorities and the power of those who lead the agencies involved-an issue we address next.

Discipline can also be imposed by professional organizations. As we've described, there is a system in most states for decertifying police officers; that means that they will lose their jobs, but might get hired by other police forces because decertification records are kept secret. ${ }^{298}$

Prosecutors, of course, are lawyers and subject to regulation by state bar associations and state supreme courts. Courts and bar associations don't have the same specific incentives to ignore misbehavior as the agencies in which it takes place, but they may be deterred by a general reluctance to publicly condemn and punish practitioners in their own profession, or they may lack the resources to investigate and sanction more than a token number of offenders, or they may just not care. For whatever reasons, they rarely discipline prosecutors, even when trial or appellate judges cite them for misconduct in cases in their courts. ${ }^{299}$

\section{b. Local leadership and local culture}

The most significant features of the American system of criminal justice-if you can call it thatare fragmentation and local control.

We have 50 states, plus the District of Columbia, the Commonwealth of Puerto Rico, several territories and the federal government, each with its own set of penal and procedural laws and its own court system. More than 90\% of criminal cases are filed in state courts, but in almost all states those courts are county rather than state institutions, and there are 3,142 counties (or equivalent geographical units) in the 50 states. As of 2007 , there were 2,330 independent prosecutorial offices that handled state law felony cases, mostly one per county. ${ }^{300}$ Policing is even more fragmented. There are about 18,000 separate police forces in the United States, 301 including more than 12,000 local police departments. ${ }^{302}$

With rare exceptions, these thousands of agencies are independent of each other and subject to local political control. Most state court judges and prosecutors are directly elected in county elections. Most sheriffs and some local police chiefs are also directly elected; the rest are appointed by elected county and municipal officials.

The institutions of national government-Congress, the Supreme Court, the President, the Department of Justice-play important roles in the administration of criminal justice across the

\footnotetext{
298 See supra Section X.2.b.ii.

299 See Kathleen M. Ridolfi \& Maurice Possley, Preventable Error: A Report On Prosecutorial Misconduct In California, 1997-2009, A Veritas Initiative Report (2010). See generally supra Section II.1.
}

300 Steven W. Perry and Duren Banks, "Prosecutors in State Courts, 2007 - Statistical Tables," Bureau of Justice Statistics (Dec. 2011).

301 Duren Banks, et al., "National Sources of Law Enforcement Employment Data," Bureau of Justice Statistics (Rev. Oct. 4, 2016).

302 Brian A. Reaves, "Local Police Departments, 2013: Personnel, Policies, and Practices," Bureau of Justice Statistics (May 2015). 
country. State governments-legislatures, governors, attorneys general, state appellate courtsare more important within their jurisdictions. But local crime labs, police departments and prosecutorial offices investigate and prosecute the overwhelming majority of crimes, and for the most part set the working policies for doing so. Any significant reforms depend on the leadership of those who administer these local agencies.

Those leaders, in turn, are constrained by the institutions they run. A practice that's been followed for years may be embedded in the institutional culture, and, as management professionals like to say, "Culture eats strategy for breakfast." 303 That doesn't mean reform is impossible-we've seen it happen-but it can be difficult. The organizational culture itself may have to be changed, which is not a simple process.

\section{i. Crime Labs}

Independent crime labs in general. Most crime labs in the United States are run by police departments.304 In many, the forensic analysts are sworn police officers, sheriffs' deputies or state troopers; in other labs, they are civilian employees of the police agencies. This creates an obvious conflict: forensic scientists should prize accuracy and clarity above all else. However, as a British court explained in 1993, "forensic scientists employed by the government may come to see their function as helping the police,"305 rather than providing accurate and complete scientific information.

The temptation to lie and cheat in order to convict a defendant is hardly limited to forensic analysts. It's what leads some law enforcement officers to manufacture evidence of guilt or hide evidence of innocence. But it's particularly troublesome for forensic evidence for two reasons:

First, there are strong reasons why forensic analysts should not work in law enforcement agencies in any capacity. The investigation of a crime is a basic police function, but testing objects and trace evidence can be and often is done just as well-or better-by independent scientists who have no other role in the case.

Second, precisely because they do not perform a core law enforcement function, forensic analysts may be viewed within police departments as playing a secondary, supportive role in investigations: police and prosecutors determine who's guilty, and take them to court; forensic experts provide ammunition to get them convicted.

When that happens, forensic officers may be rewarded for their efficiency in obtaining convictions rather than their scientific skill. That's why Joyce Gilchrist was promoted after she

\footnotetext{
303 This aphorism is routinely attributed to management guru Peter Drucker, but there is a debate about whether he ever actually said it. Andrew Cave, Culture Eats Strategy For Breakfast. So What's For Lunch? Forbes, November 9 , 2017.

${ }^{304}$ National Research Council of The National Academies, Strengthening Forensic Science In The United States: A Path Forward (2009) at 183.

${ }^{305}$ R v. Ward, [1993] 96 Crim. App. 1, 68 (U.K.).
} 
became known as the "go to" expert in difficult homicide cases in Oklahoma City. ${ }^{306}$ That's why Fred Zain, a serologist who was ultimately implicated in hundreds of cases of forensic fraud in West Virginia and Texas, was promoted to head of the West Virginia State Police crime lab a year after two officers who worked under him complained that he wrote reports based on blank laboratory slides. ${ }^{307}$ "[P] rosecutors relied on Zain because the remaining West Virginia serologists were incapable, in their view, of reaching the 'right' results." 308 After he moved on to Texas, "several prosecutors expressed dissatisfaction with the reports they were receiving ... and specifically requested that the evidence be analyzed by Zain."309

The solution to the dangers of undue influence by law enforcement is straightforward. In a 2009 report on forensic science in the United States, a panel of the National Research Council of the National Academies of Sciences, Engineering and Medicine recommended that:

"Scientific and medical assessment conducted in forensic investigations should be independent of law enforcement efforts either to prosecute criminal suspects or even to determine whether a criminal act has indeed been committed. Administratively, this means that forensic scientists should function independently of law enforcement administrators." 310

In other words, crime labs should be run by forensic scientists rather than police officers. This position enjoys broad support among legal and forensic scholars ${ }^{311}$ for reasons that are more basic and extend beyond preventing deliberate misconduct.

Forensic analysts who work for police forces are also in danger of unconsciously biasing their findings to coincide with the conclusions already reached by the officers who arrested the defendants and the prosecutors who charged them. Independent crime labs would reduce if not eliminate that danger.

In addition, independent laboratories are likely to be more effective at preventing incompetence. Joyce Gilchrist not only falsified and hid evidence in cases of charged defendants, she also erroneously cleared two capital murderers whose blood was found at the scene of their crimes. ${ }^{312}$ We know about those errors because other, innocent suspects were charged and convicted

306 See Section XII.1.c.

307 Court Invalidates a Decade of Blood Test Results in Criminal Cases, The New York Times, Nov. 12, 1993, p. A20.

308 Paul C. Giannelli, Independent Crime Laboratories: The Problem of Motivational and Cognitive Bias (2010) at 251.

${ }^{309}$ In re Investigation of the W. Va. State Police Crime Lab., Serology Div., 438 S.E.2d 501 at 513 n.16 (W. Va.

1993) (referring to deposition of T.S. Smith).

310 National Research Council Of The National Academies, Strengthening Forensic Science In The United States: A Path Forward (2009) at 24.

311 Paul C. Giannelli, Independent Crime Laboratories: The Problem of Motivational and Cognitive Bias (2010) at 251; Paul C. Giannelli, The Abuse of Scientific Evidence in Criminal Cases: The Need for Independent Crime Laboratories, 4 Va. J. Soc. Pol'y \& L. 439, 441 (1997); Sandra Guerra Thompson, Cops in Lab Coats, Carolina Academic Press (2015) at 231-32.

312 Supra Section XII.1.c. 
instead, and ultimately exonerated. We have no idea how many guilty suspects were never charged because of Gilchrist's errors in cases that did not lead to false convictions and exonerations. If Gilchrist's supervisors had been forensic scientists themselves, they might have been less dazzled by her ability to convince jurors to convict, and more aware of her professional ineptitude.

The main problem is not that police chiefs deliberately or even negligently permit bad practices in crime labs. As Professor Sandra Guerra Thompson points out, even with the best of intentions, "[o]ne cannot supervise what one does not understand." 313

The Houston crime lab. How much of a difference can the structure of a forensic lab make? Consider Houston:

In November 2002, the Houston Police Department Crime Laboratory ran into a major crisis. Two outside experts, working with a local television news program, identified serious problems in the lab's work in seven DNA and serology cases: deficient documentation of procedures and results; mistakes in analyses; errors in calculating the meaning of their results; and mischaracterizations of those results in testimony. ${ }^{314}$ Less than a month later, an audit by the Texas Department of Public Safety Crime Laboratory System concluded that the serology and DNA section of the Houston Police Crime Lab "was in shambles." 315 The section was closed immediately.

In January 2003, one of those outside experts, Professor William Thompson of the University of California, Irvine, reviewed the lab's DNA work in the rape and kidnapping conviction of Josiah $\underline{\text { Sutton }}$ and concluded that Sutton was innocent. The crime lab asked an outside lab to review its work, and that lab reported that the DNA evidence used in court was "probably incorrect." On March 10, 2003, retesting by an independent lab found that Sutton did not contribute to the semen recovered at the crime scene. He was released from prison two days later and exonerated that May. In the wave of publicity that followed Sutton's exoneration, the lab was repeatedly described as the worst in the country. ${ }^{316}$

This crisis was hardly the first sign of trouble at the Houston Police lab, but it was the most serious. ${ }^{317}$ It generated 25 investigations by the Houston Police Department, two grand jury investigations, and finally, in 2007, a major report by a former Inspector General of the United States Department of Justice, a team of lawyers and a scientific advisory board. ${ }^{18}$ That report

313 Sandra Guerra Thompson, Cops in Lab Coats, Carolina Academic Press (2015) at 182.

314 Michael R. Bromwich, "Final Report of the Independent Investigator for the Houston Police Department Crime Laboratory and Property Room" at 54-57 (June 13, 2007), [hereinafter Bromwich Report].

315 Id. at 8.

316 See, e.g., Adam Liptak, Houston DNA Review Clears Convicted Rapists, and Ripples in Texas Could Be Vast, N.Y. Times, March 11, 2003; William C. Thompson and Cliff Spiegelman, Who Should Control Houston's Crime Labs, Houston Chron., May 31, 2016.

317 Bromwich Report at 24-49; Thompson, Cops in Lab Coats, supra note 313, Ch.7, at 205-230.

318 Bromwich Report at i-ii, 58-59. 
describes the "Sutton case [as] a microcosm of the range of problems" they observed in the handling and testing of DNA evidence by the Houston Police lab: poor technical skills and inadequate training of the forensic analyst led to ambiguous results; and the analyst misrepresented those results and testified that they showed a much higher probability that Sutton participated in the crime than would have been warranted even if they had been accurate. ${ }^{319}$

In April 2014, the Houston Police Department Crime Laboratory closed its doors and transferred its responsibilities to the Houston Forensic Science Center, an independent laboratory, administered by forensic scientists, with adequate funding. The new crime laboratory is now often described as one of the best in the United States. ${ }^{320}$

Most of the problems at the old Houston Police lab involved poor performance rather than misconduct: incompetence, inadequate training, useless supervision, and insufficient resources. But misconduct played a role. In the Sutton case, a forensic analyst incorrectly analyzed the results of the DNA test she conducted, and then misreported her own findings at trial to lend support to the prosecution's theory that Sutton was guilty. The 2007 report identified several other cases of clear misconduct in DNA testing ${ }^{321}$ and in drug identification, ${ }^{322}$ and of course, many other instances will have gone undetected, especially given the lab's deeply flawed record keeping.

The new Houston Forensic Science Center has had problems, but it has dealt with them openly and effectively. ${ }^{323}$ The change in culture from the old Houston Police lab is unmistakable, even from a distance.

The process that brought about that change was drastic. The now-defunct police lab was effectively put into receivership for 10 years, major parts of its work were halted entirely and outsourced to other labs, and it was ultimately replaced entirely by a new, better funded and better run independent crime laboratory that was built from scratch, physically and organizationally. Maybe that's what it takes for a crime lab to go from worst to best in eleven years. It's a big deal, but we've seen it done. Healthier police labs could no doubt restructure and become independent over time, without ever closing down.

The Houston Forensic Science Center is not unique. In a few states, independent crime labs have existed for decades, typically under the auspices of medical examiner offices, and a couple

319 Id. at 14, 217-219.

320 Nicole B. Cásarez \& Sandra G. Thompson, Three Transformative Ideals to Build a Better Crime Lab, 34 Ga. St. U. L. Rev. 1007, 1012 (2018) ("In the short time since the laboratory assumed its corporate structure, the HFSC has already produced remarkable outcomes that set the city's laboratory apart from any other forensic laboratory in the country, earning it local, national, and international recognition."); Jed Rakoff, Jailed by Bad Science, The New York Review of Books, Vol. LXVI, No. 20 (Dec. 19, 2019) at 79-80, 85.

321 Bromwich Report at 104.

322 Id. at 153-157.

323 See Samantha Ketterer, Houston Crime Lab Fires Investigator After Alleged Testing Policy Violation, Houston Chron., October 26, 2018. 
of other jurisdictions changed from police to independent labs since the National Research Council report in 2009.324 For now, however, police crime labs are still the rule.

Caveat. Independent crime labs are not cure-alls. No formal administrative structure will overcome inadequate resources or sloppy supervision. The most notorious cases of forensic fraud in recent years involved two analysts at the Massachusetts state crime lab who falsified results in tens of thousands of drug tests at a time when the lab was run by the Massachusetts Department of Health's Office of Human Services. One of them faked tests in thousands of cases to improve her performance evaluations (Annie Dookhan);325 the other did so because she was an addict who used the drugs herself (Sonja Farak). ${ }^{326}$

Annie Dookhan and Sonja Farak managed to fly under the radar, faking results in mostly low level drug cases that overwhelmingly ended in guilty pleas. ${ }^{327}$ It's an outrage that they were able to do it in so many cases, for so long. But even a dysfunctional independent crime lab might have prevented Joyce Gilchrist and Fred Zain from achieving star status by systematic fraud in highly visible rape and murder trials.

\section{ii. Police}

In 2019, the Houston Forensic Science Center had 200 employees ${ }^{328}$ and a budget of about $\$ 27$ million. ${ }^{29}$ That year the Houston Police Department had about 6,500 employees, including 5,300 sworn police officers, ${ }^{330}$ and a budget of over $\$ 900$ million. ${ }^{331}$ The crime lab performs functions that can, if necessary, be handled by other public or private labs at other locations. The police department is responsible for a host of essential functions-emergency services, physical safety, traffic control, order maintenance, crime prevention, criminal investigation, apprehension and arrest of suspects-most of which can only be done by police officers, at the scene of the relevant events.

The radical cure that worked for the Houston crime lab-closing it down and building a new one from the ground up-is not an option for a major police force.

324 Thompson, Cops in Lab Coats, supra at 182, notes 7-9.

325 Shawn Musgrave, The Chemists and the Cover-Up, Reason, Feb. 9, 2019.

$326 / d$.

327 The Dookhan and Farak scandals ultimately resulted in the dismissal of thousands of drug convictions, mostly guilty pleas to misdemeanors. Id. These cases are not included in the Registry for the reason we discussed in III.3.c.i, on Group Exonerations: the dismissals did not alter the result of individual post-conviction re-examinations of the evidence in each case.

328 Hannah Dellinger, COVID-19 in staff puts Houston Forensic Science Center 'precariously close' to limiting crime scene responses, Houston Chronicle, June 29, 2020.

329 Houston Forensic Science Center, Inc., FY19 Budget.

330 Houston Police Department, Wikipedia, (last visited June 28, 2020).

331 City of Houston, "Proposed Operating Budget for the Period July 1, 2018 to June 30, 2019." 
Police forces in America are quasi-military organizations. Officers wear uniforms and have ranks, from Officer or Deputy, through Corporal, Sergeant, Lieutenant and Captain, to Chief, Commissioner or Sheriff. This suggests a command structure in which superior officers can institute change by issuing orders that subordinates are required to obey. That is not the case.

A patrol officer may have the lowest rank in the police hierarchy, but her job is nothing like that of a private in an infantry platoon. Most police work is done away from police precincts, by officers acting alone or in pairs, responding to calls, patrolling neighborhoods and investigating crimes. Ongoing supervision is impossible, and yet every officer has a great deal of authority over the civilians she interacts with, and discretion to decide whether and how to exercise that authority.

It doesn't help that police officers work in a notoriously insular subculture. They see themselves (with some justice) as performing indispensable, difficult and sometimes dangerous work that civilians don't understand but are often quick to criticize. That produces a sense of mission combined with cynicism, suspicion of outsiders and top commanders-and solidarity with other officers. One manifestation is the Blue Wall of Silence that protects many officers who commit crimes from exposure by fellow officers; another is resistance to change.

In addition, police chiefs are hemmed in by external forces. Local elected officials have their own agendas; influential police unions exercise substantial power in local politics, and oversee employment contracts that limit and sometimes cripple the commanders' authority to discipline subordinates. ${ }^{332}$ In some departments, the disciplinary process has become such a dysfunctional tangle of hearings and appeals that officers who ignore orders or break rules face few consequences, if any. 333

A lot has been written about reforming American police departments. A common theme is that reforms are difficult to implement, and more difficult to sustain. 334 But the reforms that have received most attention all concern basic aspects of police interactions with civilians: community relations; use of force; responsiveness to requests for assistance and to complaints; patterns of stops and arrests; race relations. The type of reforms that we're concerned with are more specific and limited: procedures for collecting and preserving testimonial and physical

332 See DeRay McKesson, et al., Police Union Contracts and Police Bill of Rights Analysis, Campaign Zero (June 29, 2016); Editorial Board, Take the lid off probes of officers tied to wrongful convictions, Chicago Sun Times, Jun. 14, 2020.

333 For example, in August 2019, two Chicago police officers were fired "a decade after they were first accused of hitting a child in their care and failing to seek medical attention for the 8-year-old boy, who suffered fractures to the face and arm that the child said was inflicted by one of the officers." The Chicago Police Board said it was "deeply troubled" that the case took so long to resolve. Jeremy Gorner, Two Chicago Police Officers Were Accused of Child Abuse. A Decade Later, They've Been Fired, Chicago Tribune, Aug. 27, 2019.

334 See Samuel Walker, Institutionalizing Police Accountability Reforms: The Problem of Making Police Reforms Endure, 32 Saint Louis University Public L. Rev. 57 (2012); Trent Ikerd \& Samuel Walker, Making Police Reforms Endure, The Keys for Success, U.S. Department of Justice Office of Community Oriented Policing Services (2010); Wesley G. Skogan (2008) Why reforms fail, Policing \& Society, 18:1, 23-34. See generally Samuel Walker \& Charles Katz The Police in America: An Introduction, 9th Edition (2017). 
evidence in criminal investigations. It may be that changes in that limited and largely reactive domain are easier to achieve.

In the worst abuses, "reform" does not require any change in operating rules. In Chicago in the 1980 , Jon Burge's regime of systematic torture was tolerated by his superiors-in fact, encouraged-and other police officers followed his sadistic lead. 335 Torture became routine. It took decades to untangle that knot, and it was a major accomplishment; institutional culture was a serious obstacle, even a culture so pathological that torture was normalized. But the end product is simply that officers have (mostly) stopped violating basic, longstanding rules against extreme physical abuse.

No one would cheer if a hospital with an unacceptable rate of post-operative mortality was finally able, in 2020, to get all surgeons to always wear sterile surgical gloves. It's not a "reform" to crack down on bad behavior that should never have been permitted. Ending an unacceptable practice might be hard-violent interrogations, or deadly surgical hygiene-but the surgeons or officers involved all knew the rules, and probably followed them most of the time.

The more novel reforms in police investigations are not prohibitions on misconduct but affirmative rules on how to gather evidence. Their goal is to obtain and preserve unbiased evidence-and, as we've mentioned, they may also reduce misconduct along the way.

\section{(a) Recorded interrogations}

There is an easy and effective remedy for misconduct in police interrogation, as we have discussed: record the whole process, preferably on video. ${ }^{336}$ Most violence and other misconduct just won't happen on camera-and if it does, it'll be there for the world to see. In addition, and perhaps more important, recording may reduce or end ugly permitted practices that also cause false confessions, and it will give judges and juries the information they need to evaluate the voluntariness and truthfulness of a confession.

All of this was known 20 years ago. Nonetheless, as of 2002, only Alaska and Minnesota required recording interrogations, both under decisions by their state supreme courts, 337 and the federal Department of Justice had a written policy against recording. 338 By 2019, 24 additional states and the District of Columbia had added statutes or court rules that required recording all

\footnotetext{
335 Supra Section XII.1.b.

336 See supra Section V.4.e.

${ }^{337}$ Brandon L. Bang, et al., Police Recording of Custodial Interrogations: A State-by-State Legal Inquiry, 20 Int'I J. of Police Science \& Management 4, 10 (2018).

338 Thomas P. Sullivan, Recording Federal Custodial Interviews, 45 Am. Crim. L. Rev. 1297, 1297 (2008).
} 
or some types of interrogations (usually homicides, especially capital murders), 339 and the Department of Justice had reversed course 180 degrees. 340

Clearly a major change is underway. At first blush, it appears to be driven by courts and legislatures. In fact, police departments have played a central role in the process.

In two states, police have implemented state-wide recording requirements independent of court mandates or legislative action-which brings the total number of states that require some recording by all police agencies to 26. In Hawaii, all four police departments in the state require recording interrogations for "serious crimes." ${ }^{411}$ And the Rhode Island Police Accreditation Commission requires all 43 Rhode Island police departments to implement mandatory recording procedures for interrogations in murder cases. ${ }^{342}$

More generally, the police have played an important role in the spread of recorded interrogations in all states, both those that have statutes or court rules and those that don't. By 2004, when no state other than Alaska and Minnesota had yet implemented a recording requirement, at least 240 police departments in 37 states had done so-most of them 10 years before or earlier. 343

Those initiatives, and the positive experiences the departments reported, paved the way for statewide changes. Every state that has adopted a statewide recording rule had police departments that did so earlier on their own. The same is true now in the substantial but dwindling minority of states without statewide rules: Numerous local police forces in those states do record some or all interrogations-and that may lead the way to more reforms at the state level. 344

\section{(b) Improved eyewitness identification procedures}

The danger of eyewitness misidentification has been well known for many years.

In 1932, Edwin Borchard's classic book, Convicting the Innocent, 345 described eyewitness errors as the most common cause of the 65 documented false convictions Borchard collected. And in

\footnotetext{
339 See Bang et al., supra note 337, at Table 1, pp. 11-12, for the status of these rules in 2017. Since then, two additional states have added recording requirements: Nevada, see Nev. Rev. Stat. Ann. § 171.1239 (West), and Oklahoma, see Okla. Stat. Ann. tit. 22, § 22 (West).

340 Office of Pub. Affairs, "Attorney General Holder Announces Significant Policy Shift Concerning Electronic Recording of Statements," U.S. Dep’t of Justice, May 22, 2014; Michael S. Schmidt, "In Policy Change, Justice Dept. to Require Recording of Interrogations," N.Y. Times, May 22, 2014.

${ }^{341}$ Bang et al., supra note 337 , at p.13.

342 ld.

343 Thomas P. Sullivan, Police Experiences with Recording Custodial Interrogations, Northwestern University School of Law: Center on Wrongful Convictions, Appendix A (2004).

344 For example, as of February 25, 2019, there were 31 such police departments in Arizona, 33 in Ohio, 22 in Tennessee, and 58 in Florida. "Electronic Recording Project" National Association of Criminal Defense Lawyers, Feb. 25, 2019.

345 Edwin M. Borchard, Convicting the Innocent, Errors of Criminal Justice (1932).
} 
1967-decades before any serious concerns about false confessions that were not obtained by violence-the Supreme Court observed that "The vagaries of eyewitness identification are well known; the annals of criminal law are rife with instances of mistaken identification," 346 and quoted an author who wrote: "The influence of improper suggestion upon identifying witnesses probably accounts for more miscarriages of justice than any other single factorperhaps...[more] than all other factors combined."347

As we've noted, 348 eyewitness identification has also been the subject of extensive psychological research-and of proposals for reform. ${ }^{349}$ For the most part, they focus on four areas of procedural reform: using a lineup administrator who does not know the identity of the suspect and therefore cannot intentionally or unintentionally suggest that a witness identify that person; proper instructions to witnesses; proper selection of fillers to avoid a suggestive lineup; and recording the entire process, including the witness's initial level of confidence in any identification that is made. 350

In 1999, the Department of Justice released a set of recommendations entitled Eyewitness Evidence, A Guide for Law Enforcement. ${ }^{351}$ The release of that "guide" is often described as a turning point for public policy on eyewitness identification, but for the most part, change on the ground didn't begin in earnest until about 2010.

In 2013, the Police Executive Research Forum released a study of identification policies and practices in 619 departments that responded to a survey that was sent in 2011 to 1,377 of the approximately 18,000 American police departments. ${ }^{352}$ They found that about " 56 percent of all responding agencies reported one or more changes in policy or procedure since 1999,"353 but half of these changes were made in 2010 or 2011.354

We can't generalize from this sample to all police departments in the country. It's likely, for example, that departments that undertook reforms were more likely to respond to the survey than those that didn't. But even if the rate of reform is overstated by a factor of five, the total

346 United States v. Wade, 388 U.S. 218, 228 (1967).

347 Patrick Wall, Eye-Witness Identification in Criminal Cases (1965).

348 Supra Section IV.3.

349 See Gary L. Wells et al., Policy and Procedure Recommendations for the Collection and Preservation of Eyewitness Identification Evidence, 44 L. \& Hum. Behav. (2020).

350 See supra IV.2.

351 National Institute of Justice, Eyewitness Identification: A Guide for Law Enforcement (Oct. 1999); see also National Institute of Justice, Eyewitness Evidence: A Trainer's Manual for Law Enforcement (Sept. 2003).

352 Police Executive Research Forum, A National Survey of Eyewitness Identification Procedures in Law Enforcement Agencies (2013).

353 Id. at xi.

354 Id. at 69-70, Table 24. 
number of departments that addressed the issue in some respect between 1999 and 2011 might be in the thousands.

There have also been changes at the state level in eyewitness identification practices. By early 2020, 31 states had some set of statewide rules, standards, or model policies-from minimal to detailed and exacting. 355 Two-thirds of these statewide reforms took place after 2011-that is, after hundreds, if not thousands, of local police departments had taken similar steps on their own.

In other words, as with recording interrogations, local police departments-the most numerous and dispersed agencies in the criminal justice system-led the way.

Local police departments are also essential for any statewide reform to succeed in practice. Virginia, for example, adopted a comprehensive model eyewitness identification policy in 2011. Professor Brandon Garrett has conducted two studies of how this policy was implemented. In 2013, he found that "the vast majority of Virginia law enforcement agencies still followed earlier and outdated" eyewitness identification practices. ${ }^{356}$ Five years later, Garrett found that "[b]y 2018, the vast majority of Virginia residents live in jurisdictions in which best practices regarding eyewitness identifications have been adopted." 357 Garrett concludes that over time, "self-policing [by local police departments]...improved police policy." 358 Professor Keith Findley studied the implementation of an eyewitness identification policy in Wisconsin, and concluded that a state mandate that provides guidance but requires police departments to adopt their own policies is more likely to succeed than one that attempts to impose a uniform policy from on high. 359

These are affirmative reforms. They set the terms for conducting interrogations and lineups correctly, and reduce misconduct along the way. A crackdown on deliberate misconductwitness tampering, for example, or concealing exculpatory evidence-might be harder to implement.

We can't say how common these police-initiated reforms have been, or how well the new rules are followed in the departments that have adopted them. Our point, rather, is that local police departments can initiate investigative reforms that are designed to reduce both errors and misconduct; we've seen it done. In fact, they seem to be more effective at that task than other law enforcement agencies.

\footnotetext{
355 National Registry of Exonerations, State Eyewitness Identification Procedures, compiled the from Innocence Project website, State Policy pages (March, 2020).

356 Brandon Garrett, Eyewitness Identifications and Police Practices: A Virginia Case Study, 2 Virginia J. of Crim. L. 1, 17 (2014).

${ }^{357}$ Brandon Garrett, Self-Policing: Dissemination and Adoption of Police Eyewitness Policies in Virginia, 105 Va. L. Rev. Online 96 (2019).

358 ld.

359 Keith Findley, Implementing the Lessons from Wrongful Convictions: An Empirical Analysis of Eyewitness Identification Reform Strategies, 81 Mo. L. Rev, 377 (2016).
} 


\section{iii. Prosecutors}

In all but a few states, ${ }^{360}$ county and district prosecutors are the most powerful actors in the American system of bringing criminals to justice. They have the exclusive power to decide whether and who to charge for most known or suspected crimes, and what charges to file. When they decide not to file charges, their decisions are unreviewable. After a defendant has been charged, they have virtually unlimited power to dismiss the case entirely, or to reduce the charges or limit the punishment in return for a guilty plea without trial, which happens in about 95\% of felony cases in which defendants are convicted. They prosecute the few criminal cases that do go to trial, and they have a major voice in the sentences of those defendants who are convicted after trial.

This enormous power is entrusted to a chief prosecutor known as District Attorney, Prosecuting Attorney, County Attorney, State's Attorney, or some other less common name. The great majority are elected directly by the voters in the geographic units they serve, usually counties. Typically, they obtain most of their funding from county boards of supervisors or other elected local politicians, but otherwise they do not report on their administrative or legal decisions to any superior officials.

A newly elected prosecutor, like a new police chief, may face a local culture that tolerates or encourages misconduct. New Orleans is a good example. ${ }^{361}$

John Thompson, as we discussed, ${ }^{362}$ was sentenced to death in 1985 because a New Orleans prosecutor hid (and eventually lost or destroyed) a critical item of physical evidence: a piece of cloth with a stain of the criminal's blood that tests had proven could not have come from Thompson. In 2012, nine years after he was exonerated, the Supreme Court considered Thompson's claim that he was the victim of a systematic practice of concealing exculpatory evidence by the Orleans Parish District Attorney's office under Harry Connick, Sr. who ran the office from 1974 through 2003. ${ }^{363}$ A year after they decided Thompson's case, the Supreme

\footnotetext{
360 In Alaska, Delaware and Rhode Island, state-wide attorneys general have primary responsibility for criminal prosecutions throughout the states. George Coppolo, States That Elect Their Chief Prosecutor, Connecticut General Assembly (Feb. 24, 2003).

${ }^{361}$ But not unique. In August 2019, for example, Chief Judge Julie A. Robinson of the United States District Court for the District of Kansas issued an opinion concluding that the "culture of the Office of the United States Attorney" for Kansas had produced a situation in which "the fairness of the adversary system is called into question by systemic prosecutorial misconduct." Specifically, the office had been systematically recording and listening to confidential conversations between defense attorneys and their clients. U.S. v. Karl Carter, Case No. 2:16-cr-20032-JAR, Document 758, Filed 08/13/19, at pp.6, 184. A former senior attorney in that office later described how he had told the United States Attorney "about systemic prosecutorial misconduct on a daily basis ... in person and in documented form," and that similar reports were made by "defense attorneys, probation officers, citizens, law enforcement and the courts," all to no avail. Mike Warner, Letter to the editor: Why I resigned from the Kansas U.S. Attorney's Office.

362 Supra Section III.3.a.

${ }^{363}$ Connick v. Thompson, 563 US 51 (2011).
}

Government Misconduct and Convicting the Innocent The Role of Prosecutors, Police and Other Law Enforcement

Page 166 • National Registry of Exonerations • September 1, 2020 
Court reversed a 1995 murder conviction from New Orleans because exculpatory evidence was concealed. 364

Justice Ginsberg, in her separate opinion in Thompson's case, summed up her view of the problem: "Connick created a tinderbox in Orleans Parish in which Brady violations [concealing exculpatory evidence] were nigh inevitable. And when they did occur, Connick insisted there was no need to change anything...." 365

The numbers support Ginsberg's description. Orleans Parish has the highest per capita exoneration rate of any county in the country. In $78 \%$ of exonerations from New Orleans, exculpatory evidence was concealed (18/23); prosecutors committed misconduct in nearly 90\% of those cases (16/18).Three of those exonerations (including Thompson's) reached the Supreme Court; in each, the defendant was sentenced to death because Connick's deputies concealed exculpatory evidence. ${ }^{366}$

Looking beyond exonerations, we know of 51 criminal cases from New Orleans in which courts of have found-or the prosecution has acknowledged-that the New Orleans District Attorney's office violated Brady, plus several others in which strong claims of Brady violations were bypassed when the convictions were reversed for other reasons. ${ }^{367}$ All of these cases were decided after Harry Connick, Sr. became District Attorney. The actual total of cases with concealed exculpatory evidence is much higher because the great majority of criminal defendants don't go to trial, don't appeal, and never learn about evidence that was deliberately concealed. Like torture in Chicago, concealing exculpatory evidence in New Orleans became routine. ${ }^{368}$

Can this sort of prosecutorial culture be changed? We think so, but we can't yet say whether it's happened in New Orleans. Leon Cannizzaro, who has served as District Attorney for the last twelve years, decided in late July 2020 not to seek reelection. ${ }^{369}$ His tenure was marred by his defense of the office against lawsuits and complaints stemming from the Connick era, and by a

364 Smith v. Cain, 565 U.S. 73 (2012).

365 Connick, supra, 563 U.S. at 108.

366 Kyles v. Whitley, 514 U.S. 419 (1995); Connick v. Thompson, 563 US 51 (2011); Smith v. Cain, 565 U.S. 73 (2012).

367 Robert Jones v. Leon Cannizzaro, Jr., E.D. LA., No. 18-cv-503, Expert Report of Professor Laurie Levenson, Document 230-2 Filed 01/28/20, pp. 8-9.

368 See Ellen Yaroshefsky, New Orleans Prosecutorial Disclosure in Practice After Connick v. Thompson, 25 Geo. J. Legal Ethics 913, 934 (2012); Janet Moore, Democracy and Criminal Discovery Reform After Connick and Garcetti, 77 Brook. L. Rev. 1329, 1342 (2012).

369 Matt Sledge \& John Simerman, New Orleans DA Leon Cannizzaro says he won't run again, ending era and controversial career, The Times-Picayunne, July 24, 2020. 
separate scandal involving the office's use of phony "subpoenas" to coerce interviews with witnesses. 370

To date, the Registry lists five exonerations of defendants who were convicted in New Orleans since Connick left office in 2003. In one, an exoneration from a 2011 conviction, we know of exculpatory evidence that was concealed. Perhaps the Orleans Parish District Attorney's Office has turned the corner on concealing exculpatory evidence, but it's too early to say, since we will see additional New Orleans exonerations from that period in the years to come, possibly more than we have already seen.

An elected prosecutor who wants to change an established pattern of misconduct can exercise much tighter control over her subordinates than most police chiefs. Unlike police officers, deputy prosecutors work primarily in their offices and in court, within a stone's throw of supervisors. Their most important tasks are conducted (or completed) in public, on the record, frequently in writing. Every formal action they take is done in the name of the head of the office, who can always override them-and who, unlike most police chiefs, usually has the power to fire or demote them.

If a county prosecutor announces a policy on handling criminal cases in her jurisdictionmarijuana possession will no longer be charged as a crime, for example, or a defendant who is charged with spouse abuse will not be allowed to plead guilty to a non-violent crime-it is likely to be carried out.

A prosecutor has the power to attack official misconduct in criminal cases by several means. She can order her deputies not to commit specific types of misconduct-concealing exculpatory evidence, for example-or direct them to follow protocols that make that misconduct impossible, such as open file discovery. She can discipline or discharge deputies who violate those orders or commit other types of misconduct. She can dismiss charges in cases that are tainted by misconduct by her own deputies or by other law enforcement officials, refuse to file charges when the arresting officer has a serious history of misconduct, or decline to call such officers as prosecution witnesses. She can prosecute police officers who intimidate or abuse defendants or witnesses, or frame innocent suspects; and she can prosecute any official who commits or procures perjury, or obstructs justice. She can reinvestigate past cases to see if misconduct was committed or miscarriages of justice occurred, and exonerate any innocent defendants she identifies.

In practice, local prosecutors' power is limited by the resources at their disposal, by political constraints, and by the independent authority of other law enforcement agencies, especially the police. All the same, they have more power to prevent misconduct in criminal cases than any other public officials.

Over the last dozen years, a growing number of prosecutors around the country have taken some of these steps. The most common is the creation of a Conviction Integrity Unit (CIU) with a

370 Id.; Nicholas Chrastil, Three qualify to run for DA on first day, Cannizzaro not among them, The Lense, July 22 , 2020. 
mandate to investigate possible wrongful convictions in the jurisdiction of the prosecutor's office, to secure exonerations when they conclude that the convicted defendants are innocent, and-in some offices - to train prosecutors and other officials to avoid future false convictions. ${ }^{371}$ Of the possible tools for preventing future misconduct, exonerating innocent defendants is the least direct-but it may be influential, especially in conjunction with other, less visible policies.

The Brooklyn District Attorney's Conviction Review Unit is one of the most vigorous CIUs in the country. It was created by District Attorney Charles Hines in 2011, and became far more active under his successor, Ken Thompson, who took office in 2014.372 All told, the Brooklyn CIU has been responsible for 27 exonerations, 21 of them murder cases. Eight of these exonerations, all murder cases, involve extreme misconduct by now-disgraced retired police detective Louis Scarcella, who lied, fabricated evidence, procured perjured testimony and coerced confessions in many cases from the late 1980 s through the 1990s, including five additional murder exonerations that the CIU did not sponsor. Nine other Brooklyn CIU exonerations involved misconduct by police officers other than Scarcella, and 10 included misconduct by prosecutors.

For example, in 2010, Wayne Martin was convicted of first-degree murder for shooting and killing the owner and an employee of a tire store in Brooklyn. In 2016, lawyers in the Brooklyn District Attorney's Office discovered that their files contained two different versions of the prosecution's summary of the evidence. The complete summary said that the only eyewitness to testify against Martin had identified another man as the gunman, but that paragraph was missing from the version that was turned over to Martin's defense attorney. A further review of the prosecution file by the CIU turned up a police report of an interview with a witness who said that he saw another suspect commit the shootings. That document had also been concealed from Martin's defense lawyer at trial. In September 2016, the District Attorney moved to dismiss the charges against Martin.

Detective Scarcella retired in 1999, more than a decade before the first of his cases unraveled. He has not been prosecuted for any crime, although he has been sued for money damages. ${ }^{373}$ Marc Fliedner, the prosecutor who obtained Wayne Martin's conviction, left the District Attorney's office before that case was reopened, and has never been disciplined for his conduct. Still, these exonerations (and others) send a message that current prosecutors and police officers might heed: Falsifying evidence of guilt and concealing evidence of innocence are not tolerated.

Since 2014, several prosecutors who campaigned on promises to reform the criminal justice system have been elected in urban counties across the country-Boston, Chicago, Houston, Philadelphia, Saint Louis, and San Francisco, among others. All inherited or created conviction

\footnotetext{
371 National Registry of Exonerations: Conviction Integrity Units.

372 In July 2020, the Kings County (Brooklyn) District Attorney's Office released a report of the 25 exonerations by that CIU that were initiated after Ken Thompson began his term, 426 Years: An Examination of 25 Wrongful Convictions in Brooklyn, New York, District Attorney, Kings County, July 9, 2020. The report contains useful descriptions of the cases and the patterns they fall into, but it's value for our purposes is limited because the office was obliged to anonymize the information reported.

${ }^{373}$ Andrew Keshner, Family of Wrongly Convicted Brooklyn Man Suing Ex-Detective Louis Scarcella Who Coerced Him Into Confession, N.Y. Daily News, Nov. 2, 2017.
} 
integrity units. Otherwise, most of the reforms they have proposed or enacted address issues other than false convictions: reducing or eliminating money bail to avoid unnecessary pretrial detention, declining to file charges for drug possession or other minor non-violent crimes, reducing the sentences they demand in return for guilty pleas or recommend after conviction at trial, and so forth.

Several of these reform-minded prosecutors have also adopted two types of proactive policies designed to prevent official misconduct and the false convictions it may cause: providing defense attorneys with open file discovery; and compiling lists of police officers whom they will not call as witnesses because of their past misconduct, or will not rely on as a basis for filing criminal charges. 374

A big issue in the background is the extent to which reform minded prosecutors will be able to reduce misconduct by police officers. Chesa Boudin, the recently elected District Attorney of San Francisco, announced an ambitious approach: "Prosecutors must do now what we should have done long ago: Prosecute offending officers and adopt measures that focus on increasing transparency, accountability and equal justice in a system plagued with impunity for the police and racial injustice." 375 Easier said than done-but it will never be done unless it's said.

This spate of reforms is a promising development, but it's too early to assess their impact. We know of $\underline{62}$ CIUs - a small number in a country with over 2,300 prosecutorial offices, but almost two-thirds of them are in counties with more than a million people. All told, those prosecutors serve a population of nearly 120 million. Between them, these CIUs have participated in 434 exonerations-but more than half of these units have worked on only a single exoneration, or none at all, and quite a few appear to be little more than window dressing. 376

If these programs remain in place-and if they spread widely across the country-they might become highly influential. Both of these conditions, however, are uncertain.

There's been considerable resistance to all these measures, and to the prosecutors who initiated them. At the national level, Attorney General William Barr has excoriated state prosecutors who "style themselves as 'social justice' reformers" but "spend their time undercutting the police, letting criminals off the hook, and refusing to enforce the law." 377 The results, Barr said, "will be predictable. More crime; more victims." ${ }^{778}$ Strong words-with no evidence to back them upbut the important opposition (like most important facts about American criminal justice) is local.

374 See, e.g., Office of the State Attorney for the Ninth Judicial Circuit, Orange \& Osceola County, State Attorney Ayala Institutes an Enhanced Brady Policy for Recurring State Witnesses; Matt Kawahara, Boudin bans prosecutions based on sole testimony of untrustworthy police officers, San Francisco Chronicle, June 15, 2020.

${ }^{375}$ Chesa Boudin, The Police Answer to Us. What Will We Do About It?, The New York Times, July 27, 2020.

376 The National Registry of Exonerations, Exonerations in 2018 (April 9, 2019); "Conviction Integrity Units," National Registry of Exonerations, (last visited July 3, 2020).

377 Michael Balsamo, Barr Defends Police, Takes Swipe at Progressive Prosecutors, PBS News Hour, Aug. $12,2019$. 378 Id. 
Conviction integrity units-the most common innovation-are popular with voters. In some elections, competing candidates have campaigned on the promise that they would do a better job of running a CIU; we know of no candidate for a position as local prosecutor who has opposed such a unit. Nonetheless, CIUs have run into opposition from other actors within the criminal justice system.

In St. Louis, when the District Attorney (on the recommendation of her CIU) moved to dismiss a 24-year-old murder conviction on grounds of innocence, the judge took the extraordinary step of asking the Missouri Attorney General to intervene. With the support of the Attorney General, the judge ruled that the District Attorney had no power to act in the case; that ruling is now on appeal.379 In Maryland, after a few trial court judges denied motions by district attorneys to vacate old convictions on the ground that the defendants were innocent, the issue was settled by the legislature, which passed a law in 2019 explicitly granting them the power to do just that. ${ }^{380}$ In 2020, Utah followed suit with the Conviction Integrity Units Act. ${ }^{381}$

Open file discovery has not met with strong political opposition that we know of. But the creation of lists of police officers who, because of prior misconduct, will not be used as witnesses or trusted in charging decisions has been attacked by police unions, in public and in court. ${ }^{82}$

The real issues, of course, are political. Larry Krasner, a former criminal defense and civil rights lawyer, was elected as District Attorney of Philadelphia in 2017, and began his term in 2018. He is probably the best known of the recent crop of progressive prosecutors, 383 and has attracted more than his share of attacks. For example:

The President of the Philadelphia's Fraternal Order of Police has not only called Krasner "anti-law enforcement" and publicly referred to him and his supporters as "the parasites of the city,"384 but placed billboards on the main highway through Philadelphia that say "HELP WANTED: NEW PHILADELPHIA DiSTRICT ATTORNEY."385

379 Richard A. Oppel, These Prosecutors Promised Change. Their Power Is Being Stripped Away, N.Y. Times, Nov. 25, 2019.

380 Justin Fenton, Maryland Lawmakers Pass Bill to Make It Easier for Prosecutors to Overturn Conviction, Baltimore Sun, April 10, 2019.

381 Utah Code 78B-9-501-503.

382 See Barry Scheck, The Integrity Of Our Convictions: Holding Stakeholders Accountable In An Era Of Criminal Justice Reform, 48 Geo. L.J. Ann. Rev. Crim. Proc. iii, xiii-xxi (2019).

383 See, e.g., Jennifer Gonnerman, Larry Krasner's Campaign to End Mass Incarceration, New Yorker, Oct. 22, 2018; Ben Austen, In Philadelphia, A Progressive D.A. Tests the Power - and Learns the Limits - of His Office, N.Y. Times, Oct. 30, 2018; Steve Volk, Philadelphia DA Larry Krasner On Radical Path to Remake Criminal Justice System,

Newsweek, Oct. 31, 2018; Steve Volk, Larry Krasner vs. Everybody: Inside the Philly DA's Crusade to Revolutionize Criminal Justice; Philadelphia Magazine, Nov. 23, 2019.

384 Joe Trinacria, Philly FOP President Blasts DA Krasner in Letter to Police Cadets, Philadelphia Magazine, March 2 , 2018.

385 'Help Wanted': Philadelphia Police Union Calling For New District Attorney in I-95 Billboards, CBS Philly, June 27, 2019.

Government Misconduct and Convicting the Innocent The Role of Prosecutors, Police and Other Law Enforcement 
In July 2019, the Pennsylvania state legislature passed a law that gives authority to the state's attorney general to prosecute some firearms violations in Philadelphia-normally an exclusive power of the district attorney-but nowhere else in the state. ${ }^{386}$

In August 2019, after a gunman injured several police officers in a shootout that lasted seven hours, the United States Attorney for the federal district that includes Philadelphia said the shooter was motivated by "the disrespect for law enforcement" that Krasner "is fostering in this community." 387

The critical question is whether Krasner will win reelection in 2021. If he's defeated after one term, his impact may be limited. In the meantime, however, in his first two years in office Krasner hired 184 of the 318 attorneys who work in his office. ${ }^{88}$ No big city police chief could exercise that level of control over the composition of their professional workforce.

Like Larry Krasner, most of the current crop of progressive local prosecutors are in their first terms in office. Historically, many local prosecutors are reelected repeatedly with support from the local police and judiciary. These prosecutors have broken that mold. If they are able to stay in office long enough, they may affect basic changes; if prosecutors in other jurisdictions follow suit, those changes may become widespread.

That remains to be seen. 389

\section{c. National Patterns}

Whatever local crime lab directors, municipal police chiefs and county prosecutors do, their direct influence, by definition, is local. If they are successful in their own territories, America will remain a patchwork of counties and districts with widely divergent practices-some effective at combating misconduct and preventing wrongful convictions, some not-unless fundamental changes take place at a national level.

The United States Department of Justice (DOJ) has some capacity to monitor and address police misconduct by local agencies. It can also lead by example, as it did in 2014, when it reversed

\footnotetext{
386 Akela Lacy \& Ryan Grim, Pennsylvania Lawmakers Move to Strip Reformist Prosecutor Larry Krasner of Authority, The Intercept, July 8, 2019.

387 Staff Reports, Philly Police Shooting Recap: Gunman Had AR-15 and Handgun, Officers Identified, McSwainKrasner Sniping, Philadelphia Inquirer, Aug. 15, 2019. As it happens, the gunman was a former federal gun-crime defendant who received a reduced sentence and was released after multiple arrests because he was an informant for the federal prosecutorial office headed by the United States Attorney who criticized Krasner. The standoff ended after Krasner went to the scene and convinced the gunman to surrender safely. Alex Yablon, Larry Krasner's Lonely, Radical Crusade to Solve America's Gun Problem, New Republic, Jan. 28, 2020.
}

388 Email to Samuel Gross from the Philadelphia District Attorney's Office, March 13, 2020.

389 On August 4, 2020, Kim Gardner, the progressive Circuit Attorney of Saint Louis City, easily won her first reelection primary (see, Joel Currier, Gardner easily wins primary for St. Louis circuit attorney, St. Louis Post Dispatch, August 5, 2020), despite a host of attacks (see, e.g., Tom Jackman, 67 current, former prosecutors defend St. Louis prosecutor from attacks in McCloskey gun case, The Washington Post, July 22, 2020), and is likely to win the general election in November. 
course and began to require electronic recording of interrogations,390_and as it could do pervasively by setting and maintaining high standards of conduct for its own agents and prosecutors. In the past several years, the department has performed poorly on both fronts. That could change.

At best, however, the role of the federal government will be limited. Any major national change in the prevalence of misconduct in criminal investigations and prosecutions will require a change in the national culture of the professions and institutions that conduct those functions. This has happened before. It may happen again.

\section{i. The United States Department of Justice}

The federal Department of Justice is a unitary national institution. It includes 94 Offices of United States Attorneys that handle federal prosecutions (and non-criminal matters) within their local jurisdictions. These offices, however, unlike local state prosecutorial offices, are headed by United States Attorneys who are appointed by the President and operate under the authority of the Attorney General of the United States. The best unit of analysis for federal criminal policy is the entire department.

The Department of Justice has very different roles in addressing misconduct by forensic analysts, by police officers, and by prosecutors.

(i) For decades, DOJ has been a national leader in the use of forensic science.

(ii) A portion of the department's case load is devoted to misconduct by local police officers, both criminal prosecutions of officers who commit crimes in the course of pursuing particular cases, and civil complaints against police departments for systematic violations of constitutional rights. DOJ can also lead police reform by example, as we mentioned.

(iii) DOJ has no authority to systematically review or monitor the conduct of state prosecutors, 391 but it could lead by setting an example of good practice for them to follow.

(a) Leading in forensic science.

The Federal Bureau of Investigation (FBI), the Department of Justice's principal law enforcement agency, administers the largest, best known, and most influential crime laboratory in the United States. Over the past several decades, the FBI has also been the home to some of 390 Office of Pub. Affairs, "Attorney General Holder Announces Significant Policy Shift Concerning Electronic
Recording of Statements," U.S. Dep’t of Justice, May 22, 2014. See supra Section XII.2.b.ii.a.

391 In theory, DOJ could charge individual prosecutors for violating 18 U.S. Code $\S 242$, which makes it a crime to "willfully subject[] any person ... to the deprivation of any rights, privileges, or immunities secured or protected by the Constitution or laws of the United States." See United States Department of Justice, Statutes Enforced by the Criminal Section. That would be appropriate, for example, if a prosecutor deliberately deprived a defendant of a fair trial by concealing critical exculpatory evidence. But doing so would be difficult in exoneration cases-if DOJ were otherwise interested-because, under 18 U.S. Code $\S 3282$, charges must be filed "within five years next after such offense shall have been committed." (Emphasis added.) As we saw in Section X.2.a., Note 206, that is usually impossible because the time lag from commission to discovery of misconduct in cases that produce exonerations is typically much longer than five years. 
the country's most prominent forensic scandals, and both the FBI and the DOJ have been accused of unreasonable defensiveness of forensic science. ${ }^{392}$ In 2009, the National Research Council in its path breaking report on forensic science in the United States, explicitly recommended against allowing DOJ to regulate forensic science because of its prosecutorial and law enforcement orientation. 393

For several years after 2009 there were signs that the DOJ and the FBI might assume a leading role in improving the use of forensic science, including preventing forensic fraud and other misconduct. The FBI cooperated with professional organizations in a comprehensive review of its troubled history of microscopic hair comparisons, ${ }^{394}$ sponsored studies of the accuracy of forensic techniques, 395 and initiated a procedure to prevent contextual bias from coloring the judgment of forensic examiners. 396

In 2013-despite the National Research Council's skepticism about allowing DOJ to regulate forensic science-the department was designated as co-administrator of the newly created National Commission on Forensic Science (NCFS), along with the National Institute of Standards and Technology. The NCFS made many useful recommendations for regulating forensic science. 397 They only bear directly on federal laboratories, but could begin to function as national guidelines for state and local laboratories.

Unfortunately, the current presidential administration disbanded the National Commission on Forensic Science in 2017,398 and has shown no interest in forensic science reform in any other context. But a start has been made. If a future administration decides to pursue the issue, there is a foundation to build on.

\footnotetext{
392 John F. Kelly \& Phillip K. Wearne, Tainting Evidence: Inside the Scandals at the FBI Crime Lab (1998); NRC, Weighing Bullet Lead Evidence, (2004); Office of the Inspector General, A Review of the FBI's Handling of the Brandon Mayfield Case, (Jan., 2006); ABS Group, Root and Cultural Cause Analysis of Report and Testimony Errors by FBI MHCA Examiners, (Aug., 2018).

393 National Research Council Of The National Academies, Strengthening Forensic Science In The United States: A Path Forward at 17 (Feb., 2009).

${ }^{394}$ Norman L. Reimer, The Hair Microscopy Review Project: An Historic Breakthrough for Law Enforcement and A Daunting Challenge for the Defense Bar, The Champion 16, July, (2013).

${ }^{395}$ E.g., The President's Council of Advisors on Science and Technology, Report to the President, Forensic Science in Criminal Courts: Ensuring Scientific Validity of Feature-Comparison Methods, 9 (Sept., 2016).

396 Office of the Inspector General, A Review of the FBI's Progress in Responding to the Recommendations in the Office of the Inspector General Report on the Fingerprint Misidentification in the Brandon Mayfield Case, 5 (June, 2011).

397 National Commission on Forensic Science, Reflecting Back_Looking Toward the Future (April 11, 2017).

${ }^{398}$ Spencer S. Hsu, Sessions Orders Justice Dept. to End Forensic Science Commission, Suspend Review Policy, Washington Post, Apr. 10, 2017; Suzanne Bell et al., A Call for More Science in Forensic Science, 115 Proceedings of the National Academy of Sciences 4541 (2018).
} 


\section{(b) Policing local police}

Chicago Police Sergeant Ronald Watts was arrested in 2012 for stealing money from an FBI informant playing the role of a drug courier. The following year, he pled guilty in federal court and was sentenced to 22 months in prison. ${ }^{399}$ After his arrest, two Chicago police officers filed a whistleblower suit in which they claimed that they had told their supervisors that Watts had been shaking down drug dealers and framing innocent people for years, but their superiors responded by calling them "rats" and assigning them to meaningless desk jobs. ${ }^{400} \underline{\text { Sixty-six }}$ defendants who had been framed for drug crimes by Watts and his subordinates have been exonerated, and many more are likely to be in the months and years to come.401

The Watts cases constitute one of seventeen "group exonerations" that we know of in which multiple defendants were exonerated after it was shown that corrupt police officers framed them for drug crimes that did not occur. ${ }^{402}$ Between them, these groups account for more than 2,500 exonerations. (The Watts cases are listed in the Registry; other group exonerations are not so far, but more will be added, as we have discussed.403)

In nine of those groups, including every one with exonerations that began since 2004, local authorities only acted after local police officers were indicted in federal court.404 The Watts cases are a good example: High-ranking Chicago police officers had known for years what Sergeant Watts and his men were doing, but took no action until after the FBI arrested him; they still have taken no disciplinary action against any of more than a dozen other officers involved, other than Watts himself and one subordinate who was also convicted in federal court.405 In Benton Harbor, Michigan, and in Camden, New Jersey, local police initiated investigations of systematic misconduct in their own departments-in Camden, it was the chief-but then asked the DOJ rather than local prosecutors to file charges. Presumably, they expected federal authorities to be more effective in prosecuting local police than county prosecutors.

In addition, since 1994, the Civil Rights Division of the Justice Department has had the authority to file civil complaints against police forces that exhibit "a pattern or practice of

399 Supra Section III.3.c.i.

400 Jason Meisner, Former Chicago Police Officer Sentenced For Stealing Money from Drug Courier, Chicago Tribune, Oct. 9, 2013.

401 See supra Section III.3.c.i.

402 National Registry of Exonerations, Mass Exonerations and Group Exonerations Since 1989 (Apr. 9, 2018).

403 See supra Section III.3.c.i.

404 See National Registry of Exonerations, Mass Exonerations and Group Exonerations Since 1989 (Apr. 9, 2018). The groups in which federal indictments preceded any local exonerations are: Philadelphia PA, 1995-2008; Tulsa OK, 2009-2012; Benton Harbor MI, 2010-2012; Camden NJ, 2010-2012; Mansfield OH, 2012; Philadelphia PA, 2013ongoing; East Cleveland OH, 2016-2017; Chicago IL, 2016-ongoing; Baltimore, MD, 2017-ongoing. These criminal charges do not face the statute-of-limitations issues that prevent the conviction of most prosecutors for misconduct in cases that produce exonerations, See supra Note 391, because, when charges are filed, the long-term patterns of criminal conduct by police that give rise to the charges are recent or still on-going.

405 See supra Section X.1.b.i.

Government Misconduct and Convicting the Innocent The Role of Prosecutors, Police and Other Law Enforcement 
conduct by law enforcement officers" that violates the Constitution. ${ }^{406}$ As of the beginning of 2017, 40 such cases had produced agreements requiring state and local police departments to change their practices. 407

These agreements focus primarily on the issues that are central to most police reform efforts: community relations, the use of force, racial discrimination in police stops and arrests, race relations generally, and so on. But the DOJ could use this process to require local police to improve evidence gathering practices. It did so in its 2013 consent decree with the City of New Orleans, which includes more than a dozen specific rules for conducting interrogations (e.g., recording is required) and photographic lineups (the officers conducting a lineup may not know who the suspect is, and so forth). 408

The United States Department of Justice has tools to address systematic violations of due process by local police. Federal prosecutions can act as a backstop to local inaction in the face of scandalous criminal behavior by police, and civil complaints can generate systemic reforms. The department has used these tools over the past few decades with substantial success in dozens of cities and counties, but it would take more resources and decisive action to drastically reduce police misconduct on a national scale. ${ }^{409}$ The administration of the current president has moved in the opposite direction, ${ }^{410}$ but that may change.

\section{(c) Setting an example on prosecutorial conduct}

Official misconduct in federal exonerations is severely lopsided. ${ }^{411}$ In state cases, misconduct by police officers is moderately more common than misconduct by prosecutors, $36 \%$ to $29 \%$. For all federal exonerations, it's the reverse and by a large margin: misconduct by prosecutors is more than two-and-a-half times as frequent as misconduct by police, $52 \%$ to $20 \%$. Among federal white-collar crimes-the most common type of federal exoneration-prosecutors committed misconduct more than seven times as often as police, in $65 \%$ of the cases compared to $9 \%$.

There are two sides to this striking pattern: a low rate of misconduct by police officers, and a high rate by prosecutors. The rate of misconduct by prosecutors among exonerations for federal

40642 U.S.C. $\S 14141$.

407 Civil Rights Division, U.S. Department of Justice, The Civil Rights Division's Pattern and Practice Police Reform Work: 1994-Present (2017). Twenty of the agreements were court-enforced consent decrees, and 20 were settlement agreements, typically known as memoranda of agreement, between the United States and the local jurisdiction.

408 United States v. City of New Orleans, Case 2:12-cv-01924-SM-JCW, United States District Court for the Eastern District of Louisiana, Consent Decree, January 11, 2013, pp, 45-48.

409 See Joanna C. Schwartz, Who Can Police the Police?, 2016 U. Chi. Legal F. 437, 448; Rachel A. Harmon, Promoting Civil Rights Through Proactive Policing Reform, 62 Stan. L. Rev. 1, 3-4 (2009).

${ }^{410}$ G.R., Without Consent Decrees, Who Will Police the Police, Economist, Jan. 28, 2019, J. Brian Charles, Justice Department Ends Era of Pushing Police Reform, Governing, Sept. 28, 2017.

411 See supra Section IX at Table 21. 
white-collar crimes is higher than for any other crime category, and the rate of misconduct by police is lower than for any other crime group. ${ }^{412}$

Federal prosecutors may be partly responsible for the low rate of police misconduct in federal white-collar exonerations. ${ }^{413}$ White-collar prosecutions are usually proactive cases that prosecutors initiate and control. The investigators are overwhelmingly federal agents, most of whom work for agencies of the Department of Justice. With that level of involvement, prosecutors can discourage or prevent a lot of misconduct by police officers.

These numbers suggest a low rate of police misconduct for all federal white-collar cases, not just the small number that produce exonerations. If the intense prosecutorial oversight that the DOJ can exercise in big-ticket federal prosecutions prevents police misconduct, greater prosecutorial involvement in police investigations might substantially reduce police misconduct in state law criminal cases as well.

Prosecutorial misconduct, however, is an entirely different story. Federal prosecutors themselves commit misconduct in nearly two-thirds of white-collar exonerations. Every one of the handful of federal white-collar exonerations with police misconduct also included prosecutorial misconduct, which suggests that the prosecutors could have prevented police misconduct in many of those cases if they were not themselves part of the problem.

As always, we can't use these data to estimate the overall rates of misconduct in federal whitecollar cases.414 Federal prosecutors may prevent a great deal of police misconduct in white-collar prosecutions - at least the types of misconduct that lead to false convictions-but misconduct by federal prosecutors themselves is the rule in those cases that end in exoneration. The resources at their disposal, and their ability to choose the targets for investigation, make the danger of misconduct by prosecutors in federal white-collar crime cases particularly disturbing-especially since the frequency of white-collar crime exonerations with misconduct by federal prosecutors has more than doubled since 2002.

ii. National culture

\section{(a) Questioning children}

So far we've discussed the culture of individual offices and departments, or particular counties. But culture also exists-and can change-at a national level. We saw that recently with improper and frequently abusive questioning of the supposed victims of child sex abuse.

From the mid-1980s through the mid-1990s, this type of misconduct fueled a national epidemic of prosecutions of child care workers and others based on false, bizarre and often impossible claims of massive patterns of abuse that police and child welfare workers extracted from the

\footnotetext{
412 This comparison includes only crimes that have 10 or more exonerations. (We do not include Fraud on this list because 32 of the 40 fraud exonerations we know about are federal white-collar cases; they constitute more than $70 \%$ of all federal white-collar exonerations.)

413 Supra Section III.3.d.

414 Supra Section III.3.d.
} 
children.415 By 2003, the Chief of Police of Minnetonka, Minnesota, explained that child sex abuse charges from 20 years earlier were being dismissed because questioning of children was "less sophisticated in 1984" and produced unreliable evidence. There are stragglers-in a few individual child sex abuse exonerations the children were subjected to improper questioning as recently as 2014-but they are now rare exceptions.

\section{(b) Forensic fraud}

A similar change seems to be taking place with forensic fraud, at least in investigations of violent crimes. ${ }^{416}$ The number of known cases has decreased steeply, from $5 \%$ of exonerations for convictions before 2002 to $0.4 \%$ for those since 2003. That might also be true for other types of forensic misconduct; our data do not address that issue directly.

Forensic evidence is much more controversial than it was 30 years ago. One of the singular effects of the DNA exonerations since 1989 has been to identify many errors and misstatements by forensic analysts that contributed to convictions of innocent defendants. In some cases, the problem was forensic fraud; in others there was misinformation but no misconduct. Either way, they brought unprecedented scrutiny to conclusions by forensic experts that had been routinely accepted without dispute.

One result of this new scrutiny was a surge in forensic lab scandals, uncovering systematic patterns of incompetence, misconduct or both. By one estimate, there were at least 70 such scandals from 1993 to $2013 .{ }^{417}$ In the process, several serial forensic fraudsters were exposed, including Fred Zain in West Virginia and Texas, Joyce Gilchrist in Oklahoma and Pamela Fish in Chicago, who between them committed forensic fraud in 20 exonerations. ${ }^{418}$ All three clusters were based on fraud committed before 1998, and nearly three-quarters of the resulting exonerations were complete before 2003 (17/25).

In 2009, the National Research Council's report on forensic science in the United States set off shock waves by concluding that many practices, tests and comparisons that were presented in courts as "forensic science" had no scientific basis. ${ }^{419}$

The message to practitioners on all sides was clear: Forensic evidence is powerful but dangerous; it requires care and scrutiny. That means the work of forensic analysts is more likely to be reviewed by supervisors in forensic labs, by police in their criminal investigations, by prosecutors preparing for trial, and by defense attorneys and defense experts in court. Scrutiny and care mean that fraud by forensic analysts (and other types of misconduct, and mistakes) is

\footnotetext{
415 See supra Section IV.4.

416 See supra Section VI.1.

417 Sandra Guerra Thompson, Cops in Lab Coats, Carolina Academic Press (2015) at 52-61.

418 See supra Section VI.1.

419 National Research Council of the National Academies, Strengthening Forensic Science In The United States: A Path Forward (2009).
} 
less likely to happen, and more likely to be identified or weeded out by prosecutors, defense attorneys or opposing experts.

The NRC report also recommended that forensic laboratories be run by forensic scientists rather than police officers. So far, we've only seen baby steps in that direction, but if independent, scientist-run labs become the rule, we expect the quality and integrity of forensic evidence to continue to improve.

\section{(c) Violence in interrogations}

Perhaps the most important cultural transformations in criminal investigation in the United States in the last hundred years is the huge reduction in the use of violence to extract confessions that occurred in the middle decades of the twentieth century.

In 1931, the National Commission on Law Enforcement (the "Wickersham Commission") published its Report on Lawlessness in Law Enforcement," which documented countless cases of violence in interrogations and concluded that:

"The third degree-the inflicting of pain, physical or mental to extract confessions or statements-is widespread throughout the country. ...Physical brutality is extensively practiced. The methods...range from beating to harsher forms of torture." 420

The revelations of the Wickersham Commission began a process that unfolded over more than 35 years and included several components.

In 1936, the Supreme Court decided the first of many cases in which it recognized that the use in court of a confession obtained by torture violates due process of law. ${ }^{421}$ In 1944, the Court unanimously agreed that "violence [in interrogations] is, an outlaw." 422 About the same time, Fred Inbau-a law professor, former police officer, and the most prominent expert on interrogations in the second third of the twentieth century-warned police about "known instances of miscarriages of justice resulting from the use of force and threats in obtaining confessions," 423 and began to try to teach police more "professional" non-violent interrogation techniques.424 Inbau's efforts evolved into what is now known as the Reid Technique of interrogation, a method that is based on isolation, deception and manipulation. This method is often coercive. It has produced its fair share of false confessions-in the last 20 years, it has become a major target of attempts to reduce the number of confessions by innocent

\footnotetext{
420 National Commission on Law Enforcement, Report on Lawlessness in Law Enforcement (1931) at p.153.

421 Brown v. Mississippi, 297 U.S. 278 (1936).

422 Ashcraft v. Tennessee, 322 U.S. 143 (1944).

423 Fred Inbau, The Courts on Confessions, The Police Digest, Dec. 1943, at 13, 15.

424 See F. Inbau, Lie Detection and Criminal Interrogation 119-33 (1st ed. 1942).
} 
suspects 425 -but it does so without violence, or (if properly applied) any other type of legally recognized misconduct. 426

In 1966, the Supreme Court decided Miranda $v$. Arizona, ${ }^{427}$ which famously requires the police to provide warnings and an opportunity to consult with a lawyer before interrogating a suspect in custody. Miranda established a formal legal structure for interrogations. It focused attention on the dangers of the process-confessions that are coerced or false or both-and created a procedural ritual to address them. It both built on and advanced the professionalization of interrogations, and of police investigations generally, that Inbau began to promote more than 20 years earlier. ${ }^{428}$

Other forces were at play as well. In particular, in 1963, in Gideon v. Wainwright, ${ }^{429}$ the Supreme Court greatly expanded the constitutional right to defense counsel in criminal prosecutions. That made it harder to hide abusive interrogations. And the disproportionate use of beatings and torture against African Americans and other minority suspects made them a specific target of the civil rights movement in the 1950 s and '6os. In any event, by 10 years after Miranda, the "third degree" was largely an historical relic. In most police departments, it simply was not done.

But not everywhere. The cultural shift that ended violence in interrogations did not reach every police department, as we have discussed in detail. It took a much later change in the culture of Cook County law enforcement-around the turn of the twenty-first century-to eliminate systematic brutality in interrogations by Chicago police officers. The result is reflected in our data: a huge decrease in the rate of violence in interrogations conducted after 2002.430

There may be a few other jurisdictions where violence is still common in interrogations, but we haven't heard of them. There are, of course, exceptions that we do know about, but they're just that, exceptions.

Are other changes of this sort already underway? Maybe. We've identified several horses; we don't know which, if any, will make it around the track.

\footnotetext{
425425 See Saul M. Kassin et al., Police-Induced Confessions: Risk Factors and Recommendations, 34 Law \& Hum. Behav. 13 (2010); Richard A. Leo, False Confessions: Causes, Consequences, and Implications, 37 J. Am. Acad. Psychiatry \& L. 332, 332-34 (2009).

${ }^{426}$ See supra Section V.1.a.

427 Miranda v. Arizona, 384 U.S. 436 (1966).

428 Richard A. Leo, The Impact of Miranda Revisited, 86 J. Crim. L \& Criminology 621, 668-69 (1996).

429 Gideon v. Wainwright, 372 U.S. 335 (1963).

430 See supra Section XI.3.
} 


\section{CODA}

Over the past 15 to 20 years, we've seen declines in a few categories of official misconduct that lead to false convictions: the use of violence and other abusive tactics in interrogations, improper questioning of children, and forensic fraud.

There may have been a general decrease over the last two decades in misconduct that leads to false convictions. It's too early to say given the available data. We're optimistic about the future, but only time will tell.

On the other hand, over the same time period, there's been a clear increase in false convictions for federal white-collar crime in cases with prosecutorial misconduct.

Rules of conduct can reduce official misconduct in handling criminal cases, especially affirmative rules that prescribe what should be done. The most valuable are rules that primarily serve central goals of criminal investigation and prosecution: obtaining and recording accurate information from witnesses and suspects; collecting and preserving probative physical evidence; providing all relevant evidence to all parties. If followed, such rules will also prevent a great deal of misconduct.

Rules, of course, are often ignored. They will be ignored in any organization that does not have the resources to perform adequately, but even with adequate resources, rules must be enforced. The most effective type of enforcement is expensive: ongoing supervision of those who work the cases, with modest contemporaneous sanctions for poor performance or misconduct.

Regardless of cost, any attempt to change operational rules, or to institute this type of supervision in an organization that does not have it, will be resisted by the established working culture. Other things equal, resistance is likely to be stronger for police-whose profession operates entirely within the criminal justice system-than for prosecutors, forensic scientists and child welfare workers, whose training and professional colleagues are more likely to overlap with other disciplines and other lines of work.

Changing a destructive work culture in an organization or a county requires determined and effective leadership-and, of course, the resources to implement the change. Success is never assured; ultimately, it may depend on local political support.

The United States has 3,142 counties, more than 2,300 separate prosecutorial offices and about 18,000 police forces. Local reforms alone will produce a patchwork of rules and practices at best, and leave many places untouched.

The only effective national remedy to entrenched forms of official misconduct is a change in the national culture that governs this work. That has happened for some types of misconduct in criminal cases, in this century and in the last. It might happen again-slowly perhaps, or gradually and then suddenly. 431

${ }^{431}$ Ernest Hemingway, The Sun Also Rises (1926). 


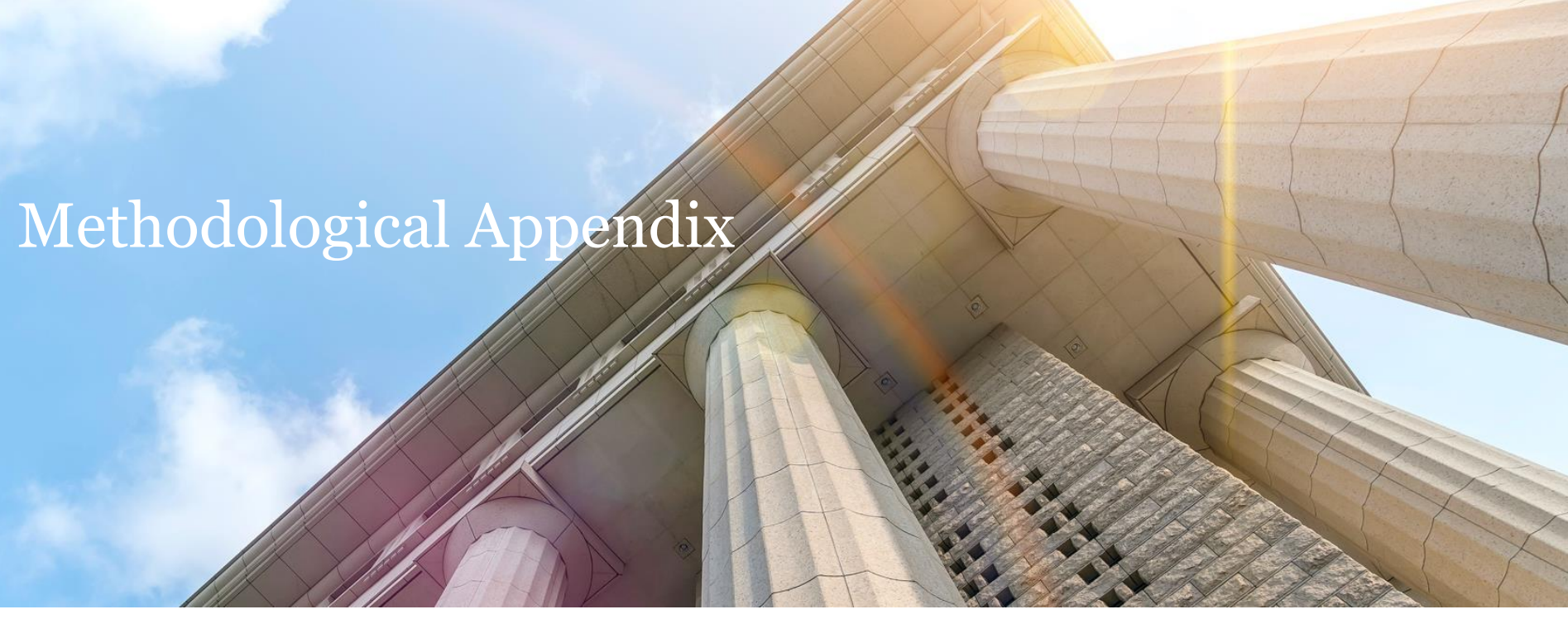

\section{The National Registry of Exonerations}

Our data are exonerations posted on the National Registry of Exonerations, an online archive of exonerations in the United States. The Registry classifies a case as an "exoneration" if a person who was convicted of a crime is officially and completely cleared based on new evidence of innocence. A more detailed definition appears here.

As we described in the body of this Report (Section II.2.a), the Registry relies entirely on nonconfidential, publicly-available sources, and it changes constantly. We add cases steadily-about 200 a year-and we change and correct old cases as we get new information, explore new issues, or modify our coding scheme.

This report is based on the first 2,400 exonerations in the Registry, those posted by February 27, 2019. Each of those cases is reported in the Registry, in a separate story under the exoneree's name and in the tabulations of cases that appear on our Detailed View, our Summary View, our Interactive Data Display, and in a variety or reports we release. Within that set of 2,400 cases, the details of available data vary depending on the issue, as we describe below.

This report contains many links to the stories of individual exonerees whom we discuss, and some data on them. The links take you to the current versions, which may have been updated since the report was written. We also include links to sets of cases, such as all exonerations with official misconduct in a particular county. Those groups may have grown to include cases posted since the first 2,400 .

\section{Coding official misconduct}

As we have discussed (Section II.2 and Section III.1) we only code as "official misconduct" acts by law enforcement officials that undermine the factual accuracy of the determination that the exoneree committed a crime. We don't code as misconduct many bad practices that increase the chance of errors-even incompetence-if the official involved did not violate a duty to behave otherwise. And, of course, we can't code the many acts of misconduct that remain hidden from us, even in cases that have ended in exoneration.

3. The datasets 
We began this study in 2014 with the first 1,361 cases that had been posted in the Registry, those listed by May 14, 2014.432 Over the following year-and-a-half we developed a detailed coding system for official misconduct and applied it to those 1,361 cases.

In 2015 and 2016, based on what we learned from that initial dataset, we developed a shorter and simpler (but still extensive) coding scheme for official misconduct that we have applied to all exonerations in the Registry. We now use that coding system for official misconduct for all exonerations in the Registry-the first 1,361, all 2,400 that are in the main dataset for this report, and all exonerations we have added since and continue to add every week.

Most of the data we report is based on the official misconduct coding that we now do for all exonerations, and applies to all 2,400 cases in our main dataset. But the data we collect is constrained by our resources. We code information by the case; we do not generally code information separately for each category of misconduct or type of official who committed misconduct. To do that would multiply the time required to process cases beyond our capacity.

As a result, we might be able to say, for example, that a particular case included misconduct by a prosecutor, and also in the same case a law enforcement officer concealed exculpatory evidence, but-unless the case included no misconduct by any other type of law enforcement officer-we cannot say whether a prosecutor was the official who concealed that evidence.

However, in our initial study of the first 1,361 exonerations posted we do have information on the categories of officials who committed particular types of misconduct. We also have more detailed information on the types of exculpatory evidence that were withheld. We report some of these data where appropriate in the text. In other words, some of our more detailed findings are based on data from a subset of the first 1,361 exonerations posted among the entire set of 2,400 exonerations we use.

Any table that is based on the 1,361 exoneration dataset includes the notation " $N=1,361$." In the text, we often include the numerators and denominators of proportions we discuss as percentages. For example, we might describe a hypothetical proportion as based on the main dataset as "25\% (600/2,400)." If we had the same proportion for the 1,361 data set the description would be similar, " $25 \%(340 / 1,361)$," but note that the actual proportion$340 / 1,361$ - is italicized.

The same applies to subcategories. For example, if we reported that some fact applies to half of all cases with official misconduct in the main data set, the denominator would be 1,296 , the number of cases out of 2,400 that include misconduct, and the description might be " $50 \%$ $(648 / 1,296)$." If we reported the same ratio for the 1,316 dataset the denominator would be 768 (the number of cases with misconduct in that dataset), and we would write " $50 \%(384 / 768)$. Note the italics.

3. Estimating the rate of fabricating evidence

432 To be precise, we started in May 2014 with 1,365 cases, but over the succeeding years four of those cases were removed because we determined that they did not in fact qualify under our definition of "exoneration." 
"Fabricating Evidence" is a set of four different types of misconduct by officials who, in one form or another, made up evidence that they falsely claimed to have witnessed themselves: forensic fraud, planted evidence, phony assaults, and fabricated confessions.

We have data on each of the components of fabricating evidence, but they come from both of the two data sets we discussed-the 1,361 cases posted by May 14, 2014, and the larger group of all 2,400 cases posted by February 27, 2019.

To get an overall estimate of the rate of fabricated evidence, we (i) determine the partial rate for each component, in whichever dataset we can; (ii) eliminate any duplicates, cases that appear to include more than one sub-species of fabricating evidence; and (iii) combine the resulting rates after duplications are removed.

(i) Determining partial rates

- $\quad$ The rate of forensic fraud is determined from the 2,400 data set: $75 / 2,400=\mathbf{3 . 1 \%}$

- The rate of planted evidence is a combination of the rates for non-group exonerations and the rate for group exonerations. For non-group exonerations we have data from the 1,361 data set: $16 / 1,361=1.2 \%$. For group exonerations, we have data from the 2,400 dataset, $66 / 2,400=2.8 \%$. No group exonerations are in 1,361 dataset, so there are no duplications, and we can combine these rates to estimate the overall rate of planting evidence among all exoneration in the study: $1.2 \%+2.8 \%=4 \%$.

- The rate of fake assaults is a combination of the rates for non-misdemeanor exonerations and the rate for misdemeanor exonerations. For non-misdemeanor exonerations we have data from the 1,361 data set: $7 / 1,361=0.51 \%$. For misdemeanor exonerations, we have data from the 2,400 dataset, $11 / 2,400=0.47 \%$. All but one of the misdemeanor cases were posted after 1,361 dataset, so for this estimate we will treat the two sets as having no duplications and combine these rates to estimate the overall rate of fake assaults among all exonerations in the study: $0.51 \%+0.47 \%=0.98 \%=\sim \mathbf{1 . 0} \%$.

- The rate offabricated confessions is determined from the 2,400 data set: $36 / 2,400=\mathbf{1 . 5} \%$

(ii) Eliminating duplicates

There are only 3 cases that have more than one of these four types of misconduct: two cases with fabricated confessions also had planted evidence, and one case with a fabricated confession included forensic fraud. For the purpose of this estimate, we removed those three cases from the total of cases with fabricated confessions, which, as adjusted, becomes:

$33 / 2,400=1.4 \%$ 
(iii) Combining partial rates:

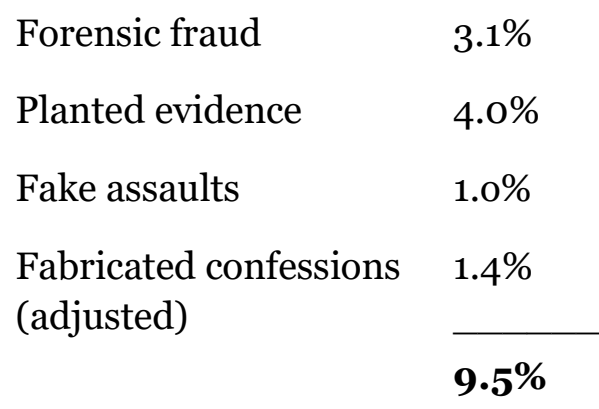

The procedure for determining the rate of fabricating evidence for particular crimes is similar, with data on each crime or set of crimes. 